WELINGTON CASTILHO GARCIA

Análise crítica da organização sindical brasileira à luz dos princípios de liberdade sindical da OIT

Dissertação de Mestrado

Orientador: Professor Doutor Ronaldo Lima dos Santos

UNIVERSIDADE DE SÃO PAULO

FACULDADE DE DIREITO

SÃO PAULO - SP

2014 
WELINGTON CASTILHO GARCIA

\section{Análise crítica da organização sindical brasileira à luz dos princípios de liberdade sindical da OIT}

Dissertação apresentada à Banca Examinadora do Programa de Pós-Graduação em Direito, da Faculdade de Direito da Universidade de São Paulo, como exigência parcial para obtenção do título de Mestre em Direito, na área de concentração Direito do Trabalho e da Seguridade Social, sob a orientação do Professor Doutor Ronaldo Lima dos Santos. 
Autorizo a reprodução e divulgação total ou parcial deste trabalho, por qualquer meio convencional ou eletrônico, para fins de estudo e pesquisa, desde que citada a fonte.

Serviço de Biblioteca e Documentação

Faculdade de Direito da Universidade de São Paulo

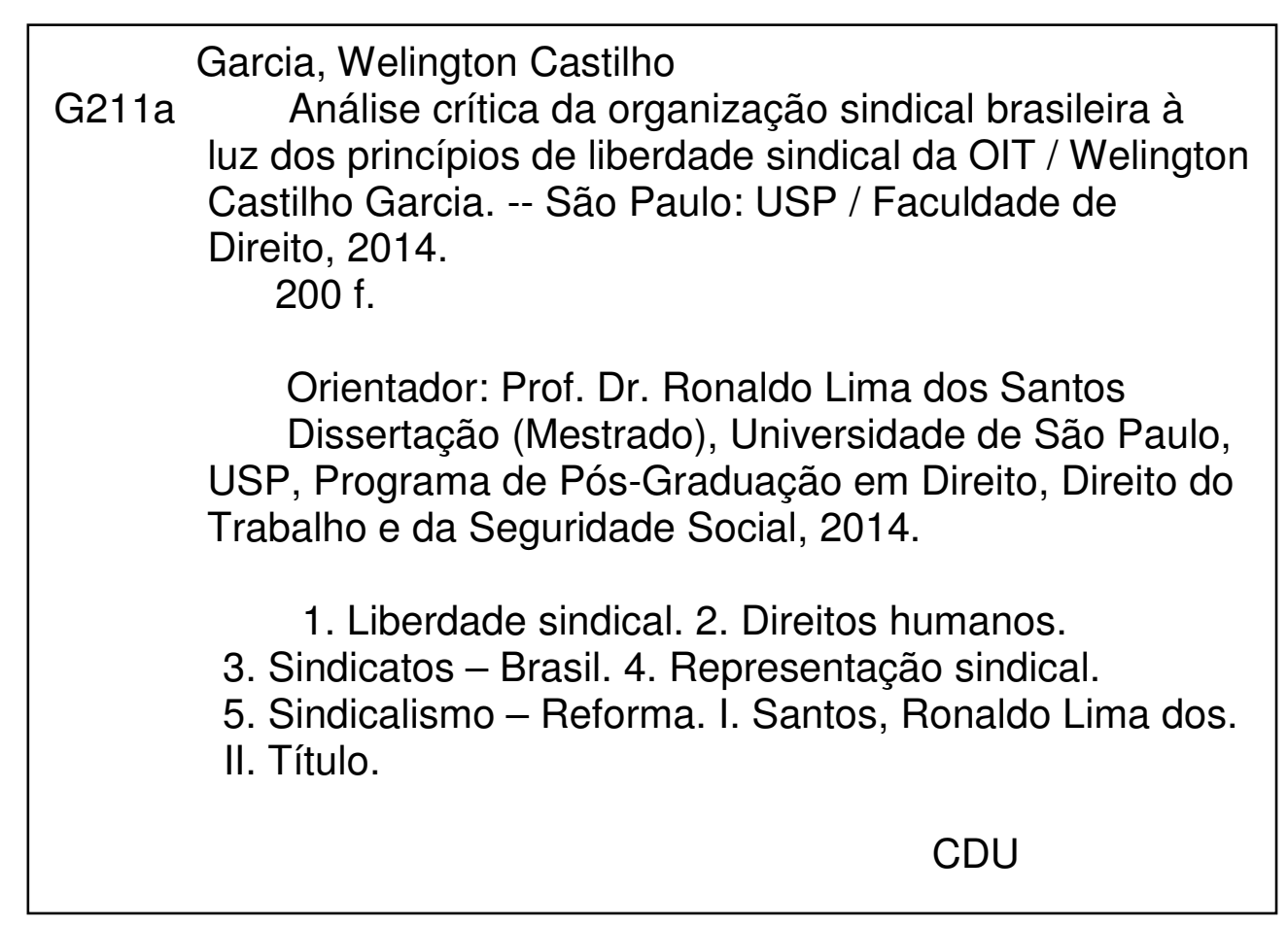


GARCIA, Welington Castilho. Análise crítica da organização sindical brasileira à luz dos princípios de liberdade sindical da OIT. Dissertação apresentada à Banca Examinadora do Programa de Pós-Graduação em Direito, da Faculdade de Direito da Universidade de São Paulo, como exigência parcial para obtenção do título de Mestre em Direito, na área de concentração Direito do Trabalho e da Seguridade Social, sob a orientação do Professor Doutor Ronaldo Lima dos Santos.

Data da aprovação:

BANCA EXAMINADORA

Prof. Dr. Instituição:

Julgamento: Assinatura:

Prof. Dr. Instituição:

Julgamento: Assinatura:

Prof. Dr. Instituição:

Julgamento: Assinatura: 
Aos meus pais,

Ademir Garcia e Neuza Teodoro Castilho Garcia, seres de luz na minha vida, cujo amor e esforços foram imprescindíveis à minha trajetória moral e intelectual.

Às minhas avós, Josepha Gonçalves Garcia (in memorian) e Maria Helena de Castilho, pela doçura de vó, carinho e exemplos de perseverança. 


\section{AGRADECIMENTOS}

Ao meu orientador, Professor Doutor Ronaldo Lima dos Santos, padrão de competência e dedicação, que durante os anos de convivência e amizade desde a graduação na Unesp em Franca, tem contribuído para o meu desenvolvimento científico e intelectual, tal como nos incentivos à carreira docente e na construção de um direito humanizado.

Ao Professor Associado Antônio Rodrigues de Freitas Junior e ao Professor Doutor José Francisco Siqueira Neto, membros da banca do Exame de Qualificação, cujos apontamentos repercutiram positivamente no desenvolvimento e aperfeiçoamento da pesquisa.

À Professora e amiga Mônica Gonçalves, um ser humano de coração nobríssimo, responsável por despertar em mim o entusiasmo pelo idioma italiano, o qual, após muitos estudos, resultou em aprovação no exame de proficiência do processo seletivo da Pós-Graduação.

Ao Professor Titular Nelson Mannrich, pelos ensinamentos e apoio durante as aulas na Faculdade de Economia, Administração e Contabilidade da Universidade de São Paulo.

À Doutora Carolina Mercante, amiga generosa e prestativa, cujos conselhos me impulsionam à luta constante pelos direitos sociais.

À Lidiane Saemy Shiratori, amiga responsável e conselheira, pela revisão textual de diversos trabalhos.

Ao amigo Duarte Alexandre Oliveira, pelas piadas e conselhos.

À Maria Terezinha G. Primo, "a Teresa”, pelas palavras confortantes e serenas, que contribuíram para meu processo salutar de introspecção. 
Aos queridos amigos de longa data, sejam de Fernandópolis, Franca, Ibitinga, Itumbiara, São José dos Campos, Votuporanga, Ilha Solteira e Capivari, bem como aqueles conquistados durante esta etapa tão importante em São Paulo.

À "Casa do Caminho" e a todos os seus integrantes, responsáveis por compartilhar momentos de paz e reflexão espiritual.

À Universidade de São Paulo e à Faculdade de Direito, pela oportunidade de realização do curso de mestrado.

À Fundação de Amparo à Pesquisa do Estado de São Paulo FAPESP, pela concessão da bolsa de mestrado e pelo apoio financeiro para a realização desta pesquisa.

Por fim, sou grato a todos aqueles não citados nominalmente, mas que de forma direta ou indireta colaboraram para a realização deste trabalho. 
Esta pesquisa foi possível graças ao financiamento da Fundação de Amparo à Pesquisa do Estado de São Paulo - FAPESP - Processo $n$. 2012/08400-5. 
"O desejo de liberdade é mais forte que a paixão.

Pássaro, eu não amaria quem me cortasse as asas.

Barco, eu não amaria quem me amarrasse no cais." 


\section{RESUMO}

GARCIA, Welington Castilho. Análise crítica da organização sindical brasileira à luz dos princípios de liberdade sindical da OIT. 2014. 200 f. Dissertação (Mestrado) - Faculdade de Direito, Universidade de São Paulo, São Paulo, 2014.

Os direitos humanos adquiriram status universal e de aplicabilidade a todos indistintamente com a promulgação da Declaração Universal dos Direitos Humanos - DUDH em 1948, cujo preâmbulo assevera a eminência dos direitos humanos e das liberdades fundamentais direcionados a todos os povos e nações. Em seguida, inicia-se a adesão de diversos países ao texto da declaração, visando à proteção na ordem constitucional interna e à consagração da dignidade da pessoa humana. Quanto às liberdades, no Direito Coletivo do Trabalho, destaca-se a manifestação do princípio (direito) de liberdade sindical, segundo a DUDH, "todo o homem tem direito a organizar sindicatos e a neles ingressar para proteção de seus interesses". Tal princípio também pode ser vislumbrado em outros diplomas internacionais, principalmente, em determinadas convenções da Organização Internacional do Trabalho - OIT. O Brasil ratificou a Declaração Universal dos Direitos Humanos e algumas convenções da OIT, no entanto, no território brasileiro prevalece a aplicação do modelo de organização sindical denominado unicidade, que condiciona a existência exclusiva de uma entidade representativa de categoria profissional ou econômica na mesma base territorial. Diante disso, a temática da pesquisa incide na relação da liberdade sindical com os principais modelos de organização adotados sob a égide dos direitos humanos fundamentais, bem como nos principais problemas enfrentados em decorrência da aplicação mitigada do referido princípio e na apresentação de medidas positivas. Ademais, propugna-se a imperiosidade de uma reforma capaz de substituir a estrutura sindical vigente, de caracteres expressivamente corporativistas, por uma metodologia consoante aos novos contornos das relações laborais.

Palavras-chave: liberdade sindical. OIT. direitos humanos fundamentais. organização sindical brasileira. reforma sindical. 


\title{
RIASSUNTO
}

\author{
GARCIA, Welington Castilho. Analisi critica del brasiliano sindacato secondo i \\ principi di libertà di associazione dell'OIL. 2014. 200 f. Tesi (Master) - Facoltà \\ di Giurisprudenza, Università di São Paulo, São Paulo, 2014.
}

I diritti umani acquisito il carattere universale e l'applicabilità a tutti senza distinzione con la promulgazione della Dichiarazione Universale dei Diritti Umani DUDU nel 1948, preambolo afferma la preminenza dei diritti umani e delle libertà fondamentali, diretti a tutti i popoli e le nazioni. Poi inizia l'adesione di diversi paesi al testo della dichiarazione, al fine di tutelare l'ordine costituzionale interno e la dedizione della dignità della persona umana. Per quanto riguarda le libertà, il diritto collettivo di lavoro, c'è la manifestazione del principio (a destra) di libertà, secondo la Dichiarazione, "ogni uomo ha il diritto di organizzare sindacati e di unirsi a loro per proteggere i loro interessi." Questo principio può essere intravisto in altri strumenti internazionali, in particolare in alcune convenzioni dell'Organizzazione Internazionale del Lavoro - ILO. Brasile ha ratificato la Dichiarazione universale dei diritti dell'uomo e delle convenzioni dell'OIL, tuttavia, in Brasile, prevale l'applicazione del modello di sindacato chiamato unità, il che rende l'esistenza unica di un organo di rappresentanza di categoria professionale o economica dello stesso territorio . Così, il tema della ricerca si concentra sul rapporto tra libertà di associazione con i principali modelli di organizzazione adottati sotto l'egida dei diritti umani fondamentali, così come i principali problemi che devono affrontare a causa della applicazione mitigato il principio e la presentazione di misure positive. Inoltre, sostiene di imperiosità di una riforma in grado di sostituire la struttura sindacale esistente, in modo significativo carattere corporativo, con una metodologia consonante ai nuovi contorni di rapporti de lavoro.

Parole chiave: libertà di associazione. ILO. I diritti umani fondamentali. Brazilian organizzazione sindacale. La riforma dell'Unione. 


\section{SUMÁRIO}

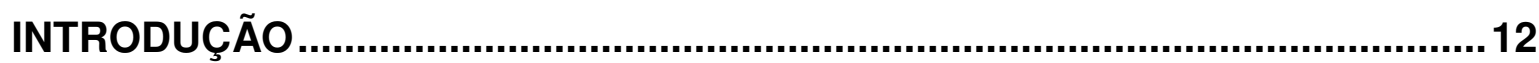

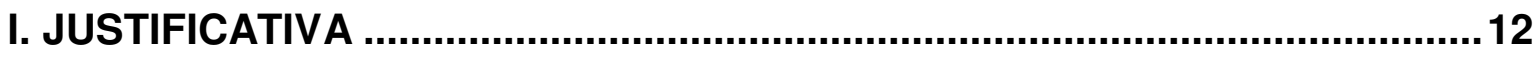

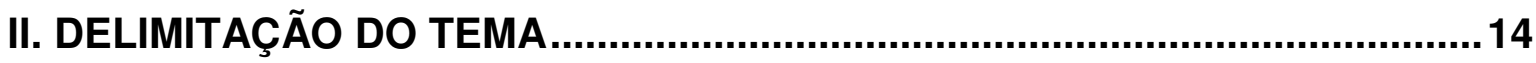

III. MÉTODOS E TÉCNICAS DE PESQUISA …....................................................16

CAPÍTULO 1 LIBERDADE SINDICAL COMO DIREITO HUMANO

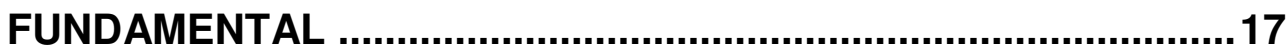

1.1 Axiologia dos direitos humanos ...............................................................

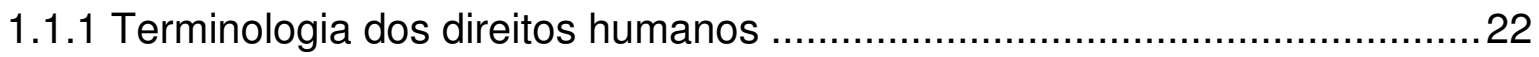

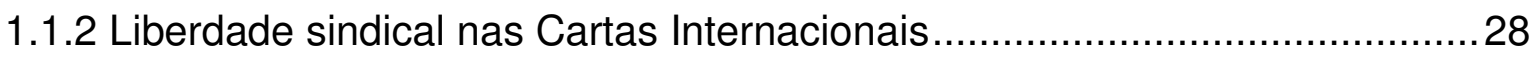

1.2 Liberdade sindical como direito humano fundamental .............................35

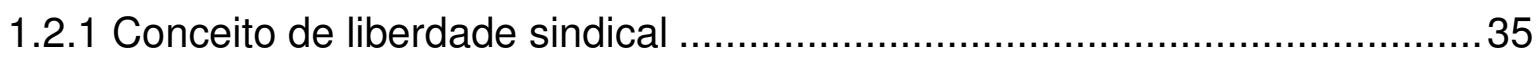

1.2.2 Normatização da Organização Internacional do Trabalho ...........................39

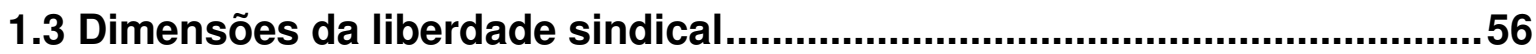

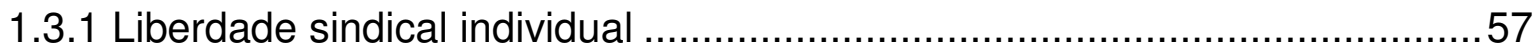

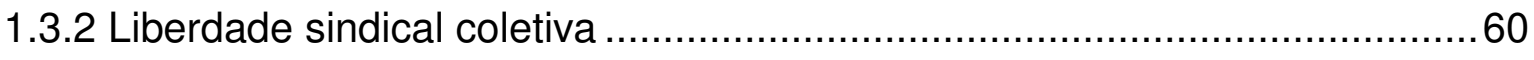

CAPÍTULO 2 ANÁLISE CRÍTICA DA ORGANIZAÇÃO SINDICAL BRASILEIRA À LUZ DOS DIREITOS HUMANOS FUNDAMENTAIS...................64

2.1 Organizações sindicais: institutos semelhantes ......................................64

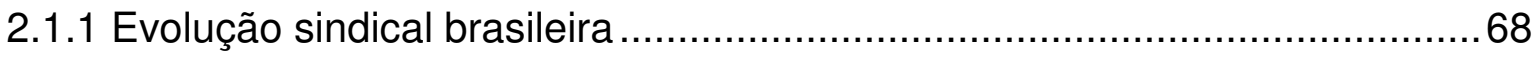

2.2 Estrutura sindical brasileira na Constituição Federal de 1988 ..................74

2.2.1 Entidades sindicais ..................................................................... 74

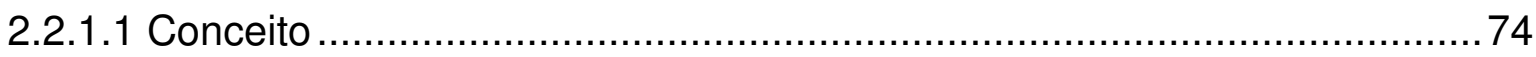

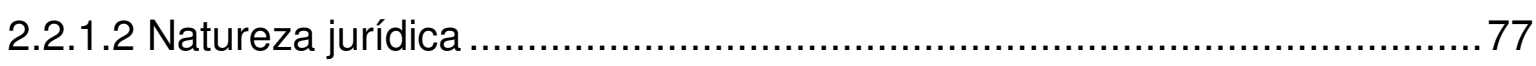

2.2.2 Sistema de representação sindical: sistema piramidal.............................. 80

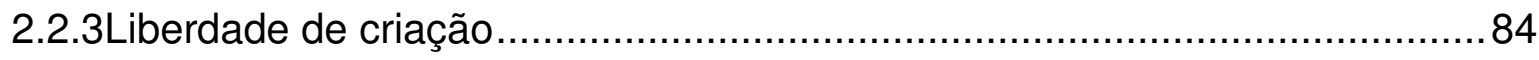


2.2.4 Liberdade de organização 89

2.2.5 Unicidade sindical e base territorial mínima

2.2.6 Critério de agregação de trabalhadores e empregadores: categoria e paralelismo sindical 100

\section{CAPÍTULO 3 REFORMA SINDICAL BRASILEIRA E OS PRINCÍPIOS DE} LIBERDADE SINDICAL .......................................................... 104

3.1 Reforma sindical brasileira: imperiosidade ............................................104

3.1.1 Proposta de Emenda Constitucional n. 369/05 ...................................109

3.2 Especificidades da estrutura sindical no projeto de reforma sindical...113

3.2.1 Extinção das fontes de sustentação econômica dos sindicatos.................119

3.2.2 Representação dos trabalhadores no local de trabalho ..........................123

3.3 Reforma sindical brasileira e a busca pela liberdade plena....................131

3.4 Perspectivas de aprovação da PEC .....................................................137

\section{CAPÍTULO 4 PROTEÇÃO CONTRA ATOS E CONDUTAS ANTISSINDICAIS}

\section{NO ORDENAMENTO JURÍDICO BRASILEIRO E} COMPARADO.

4.1 Violações à liberdade sindical: aspectos gerais ...................................142

4.1.1 Mecanismos protetivos............................................................ 147

4.1.2 Normatização internacional dos atos antissindicais .............................. 150

4.2 Sistema brasileiro de proteção contra atos e condutas antissindicais 152

4.2.1 Regramento do Anteprojeto de Lei de Relações Sindicais

4.3 Sistema protetivo contra atos e condutas antissindicais no direito comparado 160

4.4 Comitê de Liberdade Sindical e análise de queixas ..............................165

4.4.1 Queixas contra o Brasil ............................................................ 169

4.4.2 Queixas contra Portugal e Espanha................................................ 176

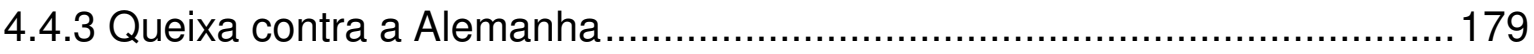




\section{INTRODUÇÃO}

\section{JUSTIFICATIVA}

Paralelamente às liberdades individuais, cultuadas pelos iluministas e mentores da Revolução Francesa de 1789, reconheceram-se, em diversos diplomas internacionais referentes aos direitos humanos, as liberdades coletivas dos grupos e a autodeterminação dos povos.

A universalidade ganhou destaque a partir das duas guerras mundiais, principalmente após a Segunda, em que foi possível constatar algumas das perversidades que o homem era capaz de realizar contra a humanidade, em consequência do materialismo ${ }^{1}$ e do egoísmo.

Diante desse contexto, mostrou-se inevitável a criação de instrumentos que promovessem a proteção do ser humano e assegurasse condições básicas, com vista à dignidade da pessoa humana. Após muitos esforços, em 1948, durante a Assembléia Geral das Nações Unidas, promulgou-se a Declaração Universal dos Direitos Humanos - DUDH, cujo preâmbulo destaca a importância dos direitos e das liberdades fundamentais concernentes a todos os povos e nações.

Os direitos humanos fundamentais surgiram da fusão de várias fontes, sendo imprescindíveis na consagração da dignidade dos seres humanos, garantindo a limitação do poder e visando ao desenvolvimento completo da personalidade humana. $^{2}$

Diante desse cenário, cumpre observar as palavras de Luigi Ferrajoli:

Esta internacionalización de los derechos fundamentales es la tercera de las tesis indicadas al principio y en la que ahora voy a detenerme. Después

\footnotetext{
${ }^{1}$ Dallari, Dalmo de Abreu. Os 50 anos da declaração universal dos direitos do homem e do nascimento de um novo direito. In: SOUZA, Carlos Aurélio Mota de; BUENO, Roberto. $\mathbf{5 0}$ anos de direitos humanos. São Paulo: Themis, 2003. p. 80.

${ }^{2}$ MORAES, Alexandre de. Direitos Humanos Fundamentais. Teoria Geral. Comentários aos arts. $1^{\circ}$ a $5^{\circ}$ da Constituição da República Federativa do Brasil. Doutrina e Jurisprudência. 7.ed. São Paulo: Atlas, 2006. p. 21.
} 
del nacimiento de la ONU, y gracias a la aprobación de cartas y convenciones internacionales sobre derechos humanos, estos derechos son «fundamentales» no sólo dentro de los Estados em cuyas constituciones se encuentran formulados, son derechos supraestatales a los que los Estados están vinculados y subordinados también en el plano del derecho internacional; no, pues, derechos de ciudadanía, sino derechos de las personas con independencia de sus diversas ciudadanías. ${ }^{3}$

Nesse contexto, a liberdade sindical surge como um direito humano fundamental inerente às relações de trabalho, previsto nos principais instrumentos de proteção humanitária, como a Carta Internacional de Diretos Humanos, da qual se extrai o art. 23, IV, da DUDH: "Toda pessoa tem direito a organizar sindicatos e neles ingressar para proteção de seus interesses".

Outrossim, a liberdade sindical é reconhecida nas principais Convenções, Declarações e Recomendações da Organização Internacional do Trabalho, a qual tem a missão de oportunizar o trabalho decente, em circunstâncias de liberdade, equidade, segurança e dignidade.

No que diz respeito ao citado direito, ressalta-se a Convenção n. 87 e na Declaração sobre os Princípios e Direitos Fundamentais no Trabalho. $O$ caput do artigo $2^{\circ}$ da citada Declaração dispõe que todos os membros da OIT têm o compromisso de respeitar, promover e tornar realidade, de boa fé e de conformidade com a Constituição (da OIT), os princípios relativos aos direitos fundamentais, dos quais cumpre observar: "a liberdade sindical e o reconhecimento efetivo do direito de negociação coletiva".

Frente aos motivos expostos, a justificativa do trabalho encontra respaldo na análise da relação entre a liberdade sindical com os modelos de organização sindical, especialmente sob a égide dos direitos humanos fundamentais, portanto, versando sobre uma temática correlata às questões atuais, diante de fatores como a crise de representatividade e a descoletivização.

As entidades sindicais já não possuem relevante autonomia ou poder negocial irrestrito, em decorrência das alterações nas relações e no mercado de trabalho. Os atores sociais se distanciaram do movimento sindical, apesar da sua eminência como instrumento da luta de classes.

\footnotetext{
${ }^{3}$ FERRAJOLI, Luigi. Derechos y garantias. La ley del más débil. Madrid: Editorial Trotta, 2004. p. 55.
} 
Consoante Enoque Ribeiro dos Santos, o sindicalismo brasileiro está afastado da maturidade e desenvolvimento ideal. É necessária uma completa reformulação da organização sindical brasileira para que possa reverter seu declínio, em se tratando de representação coletiva e da mitigação dos efeitos da descoletivização. ${ }^{4}$

A conjuntura sindical brasileira vigente necessita ser revista sob diversos aspectos, especialmente no que se refere aos elementos intervencionistas que tornam a liberdade sindical mitigada, como a unicidade sindical, a contribuição sindical compulsória e a ausência de um sistema preventivo e punitivo de condutas antissindicais; enfim, aspectos que denotam a incongruência da estrutura sindical brasileira com as relações trabalhistas.

Verifica-se, assim, que a escolha do tema, baseia-se na relevância social e jurídica da matéria, já que ela possibilita a discussão de uma temática recente, ou seja, a análise crítica da organização sindical brasileira à luz da proteção da liberdade sindical como um direito humano fundamental preconizado pela OIT; que ultrapassa os lindes do Direito do Trabalho e adquire caráter interdisciplinar.

\section{DELIMITAÇÃO DO TEMA}

A pesquisa é concentrada no estudo da liberdade sindical no âmbito da organização sindical brasileira como um direito humano fundamental, o qual deve ser reafirmado diuturnamente em decorrência das violações sofridas, que impedem ou limitam a fruição de conteúdos básicos e indispensáveis à dignidade humana dos atores sociais, principalmente dos trabalhadores. Para tanto, utilizam-se como parâmetros os princípios e direitos consagrados pela Organização Internacional do Trabalho - OIT.

Inicialmente, a análise percorre os aspectos basilares dedicados à temática humanitária, como o posicionamento esparso dos princípios axiológicos

\footnotetext{
${ }^{4}$ SANTOS, Enoque Ribeiro dos Santos. Direitos Humanos na Negociação Coletiva: Teoria e Prática Jurisprudencial. São Paulo: LTr, 2004.p. 60-62.
} 
de direitos humanos em diplomas clássicos, como a Declaração de Independência dos Estados Unidos, até o agrupamento na Declaração Universal dos Direitos Humanos.

Em seguida, apresenta-se a liberdade sindical nos principais diplomas internacionais, como na Carta Internacional de Direitos Humanos e nas Convenções da OIT, o que possibilita a conceituação do instituto a partir da doutrina comparada e brasileira, bem como o alcance das suas dimensões.

Posteriormente, recorre-se a breves observações terminológicas para individualizar a matéria sindical. Outrossim, expõem-se os principais aspectos da evolução sindical nacional. Posteriormente, fixa-se na caracterização da estrutura sindical brasileira, confrontando-a com outros sistemas para demonstrar a inadequabilidade de determinados conteúdos, como o modelo organizacional de unicidade sindical.

Após discorrer sobre o sistema sindical vigente, examinam-se os pontos essenciais da Proposta de Emenda Constitucional n. 369/2005 e do Anteprojeto de Lei de Relações Sindicais, cujos questionamentos centram-se na avaliação da imprescindibilidade de uma reforma, especialmente na forma de manutenção financeira das organizações sindicais e na concretização da representação dos trabalhadores no local de trabalho. Além disso, o exame das propostas permite avaliar se a possível aprovação resultaria no estabelecimento pleno da liberdade sindical.

Por fim, dedica-se ao estudo das violações de liberdade sindical no ordenamento jurídico brasileiro e comparado. Intenta-se identificar as principais condutas antissindicais praticadas pelo empregador, Estado ou organizações sindicais. Em seguida, coteja-se o atual sistema brasileiro de proteção contra atos e condutas antissindicais com o regramento do Anteprojeto de Relações Sindicais. Ademais, examina-se o papel do Comitê de Liberdade Sindical e as consequências das suas decisões na órbita internacional, também se analisa as queixas contra Estados que adotam a unicidade, a pluralidade e a unidade espontânea. 


\section{MÉTODOS E TÉCNICAS DE PESQUISA}

O estudo da liberdade sindical, como um direito humano fundamental, comporta uma análise sob diversas perspectivas. Em decorrência disso, é necessário ponderar os métodos utilizados com o intuito de delinear nitidamente a proposta do presente trabalho, pois a insuficiência de ferramentas e técnicas de pesquisa conduz à ambiguidade e desordem. Para tanto, são utilizados os seguintes métodos: indutivo, dedutivo, descritivo e analítico.

No que se refere ao procedimento, além do emprego da dogmática jurídica e do direito comparado, consentâneos às pesquisas jurídicas, adota-se também o método histórico, em virtude da necessidade de se realizar um estudo evolutivo de conteúdo, como nas principais normas jurídicas que regularam conteúdos acerca das entidades sindicais ao longo da História.

Quando se recorre aos conceitos gerais e genéricos, emprega-se o método dedutivo, por exemplo, ao examinar a liberdade sindical no direito estrangeiro e depois observá-la à luz do ordenamento jurídico brasileiro. Ao se inquirir um fato conhecido para extrair conclusões gerais, aplica-se o método indutivo; e também o método analítico-sintético ao proceder-se à apreciação de textos jurídicos.

Ademais, as relações laborais possuem caráter interdisciplinar, por isso, torna-se relevante a comunicação do Direito do Coletivo do Trabalho com outros ramos, como o Direito Constitucional, Civil e Internacional.

No que tange às técnicas de pesquisa propriamente, cabe mencionar a utilização das fontes primárias: normas internacionais, legislação estrangeira, normas coletivas, súmulas dos tribunais superiores, jurisprudência, verbetes do Comitê de Liberdade Sindical da OIT, e das fontes secundárias: pesquisa bibliográfica (tratados, manuais, artigos de periódicos) e estudos promovidos pela Organização Internacional do Trabalho. 


\section{CAPÍTULO 1 LIBERDADE SINDICAL COMO DIREITO HUMANO FUNDAMENTAL}

\subsection{Axiologia dos direitos humanos}

A Declaração Universal dos Direitos Humanos - DUDH, promulgada pela Assembleia Geral das Nações Unidas em 10 de dezembro de 1948, é um dos documentos mais importantes no que diz respeito à universalização dos princípios axiológicos de direitos humanos, quais sejam: liberdade, igualdade e fraternidade (ou solidariedade).

Anterior a esse marco, vislumbra-se a disposição esparsa dos referidos princípios. Diante disso, optou-se pela recorrência de alguns documentos e momentos da História da humanidade a partir do final da Idade Moderna, com o intuito de apresentar as principais transformações até o desdobramento atual.

Em 4 de julho de 1776, os Estados Unidos da América, por meio do seu Congresso Geral, aprovaram a sua Declaração de Independência, elaborada, principalmente por Thomas Jefferson, e a partir da qual as treze colônias da América do Norte tornar-se-iam independentes do Reino Unido após um período de conflitos. A aprovação resultou na ruptura com o Estado absolutista inglês e a consequentemente criação de uma república.

A Declaração ${ }^{1}$ de Independência consagrou-se como o primeiro diploma político a reconhecer, "a par da legitimidade da soberania popular, a existência de direitos inerentes a todo ser humano, independentemente das

\footnotetext{
1 O reconhecimento da soberania, nessa época, refletiu-se também no próprio vocábulo "declaração". Anteriormente, os documentos utilizavam outras denominações, como "Carta" (Magna Carta - 1215), "Petição" e "Bill' (Bill of Rights - 1689). As palavras "Petição" e "Bill" mostraram-se inapropriadas, porquanto referenciam o ato de solicitar algo a um ente superior, já o verbete "Carta" remete a uma certidão ou escritura. Por sua vez, a Declaração da Independência não se limitou a um ajuste entre as partes (governante e povo) ou a mera concessão de benefícios, mas, sim, o reconhecimento de direitos inerentes à condição humana. In: HUNT, Lynn. A invenção dos direitos humanos: uma história. Trad. Rosaura Eichenberg. São Paulo: Companhia das Letras, 2009. p. 114-115.
} 
diferenças de sexo, raça e religião, cultura ou posição social". ${ }^{2}$ Tal soberania é comprovada mediante a análise de alguns fragmentos da Declaração, por exemplo:

[...] governos são instituídos entre os homens, derivando seus justos poderes do consentimento dos governados; que, sempre que qualquer forma de governo se torne destrutiva de tais fins, cabe ao povo o direito de alterá-la ou aboli-la e instituir novo governo, baseando-o em tais princípios e organizando-lhe os poderes pela forma que lhe pareça mais conveniente para realizar-Ihe a segurança e a felicidade.

O "ser feliz" enfatizado no preâmbulo, não invoca um direito em si, inerente ao indivíduo, o objetivo foi demonstrar a consecução da dignidade humana por meio da dependência de garantias de oportunidades para a efetivação da felicidade. ${ }^{3}$

A despeito do prestígio da referida Declaração de Independência, não se pode olvidar da Declaração de Direitos de Virgínia, de 12 de junho de 1776, pois, houve a disposição de um rol específico de direitos do homem e do cidadão direcionado não somente ao povo norte-americano, mas pertencentes a todos os indivíduos indistintamente em decorrência da dignidade humana de cada $u m .{ }^{4}$ Sendo assim, destaca-se:

Artigo $1^{\circ}$ - Todos os homens nascem igualmente livres e independentes, têm direitos certos, essenciais e naturais dos quais não podem, por nenhum contrato, privar nem despojar sua posteridade: tais são o direito de gozar a vida e a liberdade com os meios de adquirir e possuir propriedades, de procurar obter a felicidade e a segurança.

O princípio axiológico da liberdade está associado à ideia de autonomia, "uma sociedade livre é aquela que obedece às leis que ela própria estabelece e aos governantes por ela escolhidos". A liberdade foi classificada em

${ }^{2}$ COMPARATO, Fábio Konder. A afirmação histórica dos direitos humanos. 6.ed. rev. e atual. São Paulo: Saraiva, 2001. p. 107.

${ }^{3}$ Ibid., p. 107.

A felicidade disposta no texto da Declaração da Independência também é encontrada em outro excerto, qual seja: "Consideramos estas verdades como evidentes por si mesmas, que todos os homens são criados iguais, dotados pelo Criador de certos direitos inalienáveis, que entre estes estão a vida, a liberdade e a procura da felicidade".

${ }^{4}$ MUNOZ, Jairo M. De los derechos humanos a los derechos de los pueblos. Una historia de libertad, democracia y auto determinacion. Franciscanum: Revista de las ciencias del espiritu. Bogota, v.32, n.94, p.31-44, ene./abr. 1990. p. 35-36. 
"liberdade pública" (sentido político de autogoverno) e "liberdade privada" (contraposição à ingerência governamental). Conceitos distintos, mas devem se relacionar, já que "a liberdade política sem as liberdades individuais não passa de engodo demagógico de Estados autoritários ou totalitários" ${ }^{5}$

Em 26 de agosto de 1789, durante a Revolução Francesa, a Assembleia Nacional Constituinte da França aprovou a Declaração dos Direitos do Homem e do Cidadão $^{6}$, especialmente em contraposição ao longo regime monárquico, o que favoreceu o afloramento dos princípios de liberdade, igualdade e fraternidade. Nesse contexto, o princípio axiológico da igualdade fundamentouse na isonomia do indivíduo perante a lei. A sociedade deixou de se estruturar em estamentos e se dividiu em proprietários e trabalhadores. ${ }^{7}$

A Declaração da Independência dos Estados Unidos e a Declaração de Direitos do Homem e do Cidadão impulsionaram o reconhecimento político dos direitos humanos em caráter natural, igualitário e universal. Destarte, afastou-se o entendimento e aplicabilidade proselitista, sobreposta pelos direitos humanos ou direitos naturais universais. ${ }^{8}$

Por isso, cumpre observar o artigo $1^{\circ}$ da Declaração de origem francesa:

Os homens nascem e são livres e iguais em direitos. As distinções sociais só podem fundar-se na utilidade comum.

A Declaração de Direitos do Homem e do Cidadão não representou uma luta por direitos das coletividades, essencialmente significou o rompimento com os padrões absolutistas, já que a sociedade francesa de um modo geral não concebia a intervenção estatal na vida do indivíduo, ambicionava modificações

\footnotetext{
${ }^{5}$ COMPARATO, Fábio Konder, op. cit., p. 75-76.

${ }^{6}$ O conteúdo da Declaração dos Direitos do Homem e do Cidadão adveio de diversas fontes, particularmente pelo trabalho do Marquês de Lafayette e do provável auxílio de Thomas Jefferson. Notavelmente, houve a mudança na direção do poder, cuja soberania foi reservada à nação. Certas palavras (por exemplo: rei, nobreza ou igreja) foram substituídas pelas expressões "homens", "homem", "todo homem", "todos os homens", "todos os cidadãos". Contudo, historiadores relatam e questionam o paradoxo existente entre a aclamação da universalidade de direitos e certos ambientes inviabilizadores da igualdade sob a forma "autoevidente", pois algumas categorias (escravos e mulheres, por exemplo) eram excluídas do processo político. Além disso, Thomas Jefferson foi um senhor de escravos e o Marquês de Lafayette, um aristocrata. In: HUNT, Lynn. Op. cit., p. 13-14; 16-17.

${ }^{7}$ COMPARATO, Fábio Konder, op. cit., p. 76.

${ }^{8}$ Ibid., p. 19-20
} 
nas estruturas do governo, nesse contexto, o liberalismo enraizou-se. Ademais, caracterizou-se pelo universalismo, individualismo e a abstração.

O caráter universal diz respeito à sua abrangência, não está adstrita exclusivamente ao povo francês, abrange o indivíduo originário de qualquer nação e, correlaciona-se à ideia de igualdade entre os homens. No que concerne ao aspecto individual, valoriza-se o homem de maneira singular, não há referência aos grupos (família, coletividades públicas ou profissionais). Desse modo, as liberdades previstas não são coletivas, incidem sobre um direito de agir e não para fazer reivindicações perante o Estado. Por fim, a abstração emana da proclamação de princípios e da exposição de noções gerais. ${ }^{9}$

Em 03 de setembro de 1791, a Assembleia Nacional da França aprovou a Constituição do país, cujo preâmbulo tem como resultado a própria Declaração dos Direitos do Homem e do Cidadão. Tal documento também realçou o "caráter antiaristocrático e antifeudal do novo regime político" 10; além disso, dispôs de forma expressa acerca do princípio da fraternidade, por exemplo: "Haverá feriados nacionais para manter a memória da Revolução Francesa, manter a fraternidade entre os cidadãos, e anexá-los à Constituição, às leis e à pátria”.

Por outro lado, o Estado francês também editou normas que foram de encontro ao direito de associação, conforme ocorreu em 14 de junho de 1791, quando entrou em vigor a Lei Le Chapelier, cujo objetivo era impedir a formação de sindicatos, greves e a união dos trabalhadores, tendo em vista a manutenção dos ideais liberalistas. Assim, veja-se:

Art. 1. L'anéantissement de toutes espèces de corporations des citoyens du même état ou profession étant une des bases fondamentales de la constitution française, II est défendu de les rétablir de fait, sous quelque prétexte et quelque forme que ce soit. ${ }^{11}$

À vista disso, ficou proibida a formação de grupos para a defesa de interesses específicos comuns, priorizou-se o interesse privado à vontade

\footnotetext{
${ }^{9}$ ISRAEL, Jean-Jacques. Direito das liberdades fundamentais. Trad. Carlos Souza. Barueri/SP: Manole, 2005. p. 89-91.

${ }^{10}$ COMPARATO, Fábio Konder, op. cit., p. 146.

11 "A extinção de todos os tipos de corporações de cidadãos de interesses semelhantes ou profissionais é uma das bases fundamentais da Constituição francesa, proibe-se o restabelecimento de fato, sob qualquer pretexto e de qualquer forma que seja." (Tradução livre)
} 
geral. Desse modo, era permitido somente o acordo realizado entre um indivíduo e outro, uma vez que o pacto coletivo resultaria em pressão do grupo, colocando em conflito a igualdade jurídica. ${ }^{12}$

Em caráter de complementaridade à Lei Le Chapelier, havia os artigos 414 e 416 do Código Penal francês, cujo conteúdo considerava crime a reunião de mais de vinte pessoas, mesmo quando não impediam a atuação profissional e impunha meios de embaraçá-la. Somente em 1864, o ambiente tornou-se propício à criação dos sindicatos, com destaque para a fundação, em Londres, da Primeira Internacional (oficialmente, Associação Internacional dos Trabalhadores), especialmente com a participação de Henri Louis Tolain. ${ }^{13}$

Portanto, a existência das associações na sua primeira fase desenrola-se sob o manto da ilegalidade, já que eram tidas por ilícitas. Todo o processo organizativo interno, como a elaboração de estatutos e a eleição de dirigentes, acontecia secretamente. ${ }^{14}$

Portanto, os movimentos denominados Revolução Americana e Francesa, que serviram de cenário para a aprovação das mencionadas Declarações, possuíram conteúdo individualista, especialmente, para a consolidação da democracia burguesa. Somente a partir da segunda etapa da Revolução Francesa, visualizou-se a proclamação de direitos sociais do homem, tais como: direitos relativos ao trabalho e aos meios de existência, assim como o direito de proteção contra a indigência; porém, a concretização desses direitos caberia à sociedade e não ao ente público. ${ }^{15}$

As mencionadas Declarações inspiraram a Declaração Universal dos Direitos Humanos, a qual proclama:

Artigo I. Todas as pessoas nascem livres e iguais em dignidade e direitos. São dotadas de razão e consciência e devem agir em relação umas às outras com espírito de fraternidade.

\footnotetext{
${ }^{12}$ VARGAS, João Tritan. Qual é o liberalismo da Lei Chapelier? Seu significado para os contemporâneos e para a historiografia francesa dos séculos XIX e XX. Revista Mundos do Trabalho, vol. 3, n. 5, janeiro-junho de 2011, p. 213-232. p. 218.

${ }^{13}$ MAGANO, Octávio Bueno. Organização sindical brasileira. São Paulo: Ed. Rev. dos Tribunais, 1981. p. 31.

${ }^{14}$ MAZZONI, Giuliano. Relações coletivas de trabalho. Trad. Antonio Lamarca. São Paulo: Ed. Revista dos Tribunais, 1972. p.7.

${ }^{15}$ HERKENHOFF, João Baptista. Curso de direitos humanos. Gênese dos direitos humanos. Guarulhos/SP: Acadêmica, 1994. v. I. p. 57.
} 
Não obstante 0 caráter universal das supracitadas normas internacionais, somente com a DUDH "pela primeira vez em escala planetária, o papel dos direitos humanos na convivência coletiva, pode ser considerada um evento inaugural de uma nova concepção da via internacional." Esse entendimento conduz à histórica dimensão internacional dos direitos humanos voltados ao trato coletivo. ${ }^{16}$

Visando à correção e superação do individualismo, baseado nas liberdades privadas e na isonomia, o movimento socialista impulsionou o princípio axiológico da solidariedade como dever jurídico, o qual se assenta na imprescindibilidade de aplicar a "justiça distributiva", objetivando a compensação de bens e vantagens entre as classes sociais. ${ }^{17}$

Por isso, verifica-se que a Declaração de Independência dos Estados Unidos e a Declaração dos Direitos do Homem e do Cidadão dispuseram enfaticamente apenas sobre a liberdade e a igualdade. Cuidaram do homem estritamente sob o aspecto individual, enquanto a DUDH enfatiza a importância da solidariedade entre as pessoas, bem como a exteriorização de outras liberdades, como o direito à reunião e associação.

É possível encontrar os princípios axiológicos de direitos humanos em outros textos, entretanto, a tríade sagrada ${ }^{18}$ adquiriu prestígio com a promulgação da Declaração Universal dos Direitos Humanos. Isso se deve, essencialmente, pelo enredo abarcado à edição do documento, isto é, após as destruições e os crimes da Segunda Guerra Mundial, cujos algozes subjugaram povos e nações em nome de causas como o autoritarismo e a obtenção de poder.

\subsubsection{Terminologia dos direitos humanos}

Os direitos humanos sob o enfoque da proteção internacional são aqueles inerentes a todo ser humano, de maneira que se garantam os

\footnotetext{
${ }^{16}$ LAFER, Celso. Declaração universal dos direitos humanos (1948). In: MAGNOLI, Demétrio.

(Org.) História da paz: os tratados que desenharam o planeta. São Paulo: Contexto, 2008.

${ }^{17}$ COMPARATO, Fábio Konder, op. cit., p. 77.

${ }^{18}$ Expressão utilizada por Fábio Konder Comparato. In: COMPARATO, Fábio Konder, op. cit., p. 228.
} 
instrumentos mínimos para seu desenvolvimento. Isso significa que não há distinção entre a aplicação do conceito, independente da nacionalidade ou das características particulares de cada povo nas diferenciadas regiões do planeta quando se pauta pelo enfoque do universalismo.

Tais direitos receberam nomenclatura diversificada no decorrer do desenvolvimento e formação da História, sobretudo, na aplicação de termos dessemelhantes, por vezes examinados como sinônimos.

Os valores experimentados pelas sociedades em diversas épocas demonstraram a importância (ou, em dadas circunstâncias e interesses, a trivialidade) e a quem era dedicada a temática, assim como as dimensões da liberdade, uma vez que por muito tempo relativizou-se o direito de "ser livre".

Inicialmente, a expressão "direitos humanos" surgiu na França (1763), congênere a "direito natural", entretanto, sem intensidade. Na década de 1760, elaborou-se o termo droits de l'homme (direitos do homem), com peculiar aplicação após a obra "O contrato social" de Rousseau. Mas, foi o jurista inglês Willian Blackstone (1723-1780) que os apresentou como sendo a "liberdade natural da humanidade", bem como os "direitos absolutos do homem". ${ }^{19}$

O nascimento dos direitos humanos e as suas várias nomenclaturas fundamentam-se nos elementos intrínsecos dos Estados, tal como a política e a economia em diferentes momentos da sua história particular. Essa heterogeneidade explica a evolução progressista dos direitos humanos após a Segunda Guerra Mundial, defronte à propagação individual no território de cada nação, por vezes conservadora. ${ }^{20}$

Atualmente, a terminologia está dividida em direitos humanos, direitos fundamentais e direitos humanos fundamentais.

Consoante Dalmo de Abreu Dallari, os direitos humanos são apresentados como "uma forma abreviada de mencionar os direitos fundamentais da pessoa humana. Esses direitos são considerados fundamentais porque sem

\footnotetext{
${ }^{19}$ HUNT, Lynn, op. cit., p. 21-23.

${ }^{20}$ AGUILAR CAVALLO, Gonzalo. Derechos fundamentales-derechos humanos. ¿Una distinción válida en el siglo XXI? Boletin Mexicano de Derecho Comparado. México, v.43, n.127, p.1571. ene./abr. 2010. p. 21-22.
} 
eles a pessoa humana não consegue existir ou não é capaz de se desenvolver e de participar plenamente da vida". ${ }^{21}$

Para João Baptista Herkenhoff, os direitos humanos são aqueles essenciais à pessoa, "pelo fato de ser homem, por sua natureza humana, pela dignidade que a ela é inerente. São direitos que não resultam de uma concessão da sociedade política. Pelo contrário, são direitos que a sociedade política tem o dever de consagrar e garantir". ${ }^{22}$

Para Flávia Piovesan, "são concebidos como uma unidade indivisível, interdependente e interrelacionada, na qual os valores da igualdade e liberdade se conjugam e se completam". ${ }^{23}$

É notável a substancialidade dos direitos humanos na manutenção da qualidade de vida dos indivíduos. Nesses termos, torna-se impraticável a utilização mitigada da proteção humanitária, um Estado não pode, por exemplo, ratificar uma convenção (sobre direitos humanos) apenas com o intuito de praticar e adaptar conteúdos pertinentes ao seu ordenamento interno e olvidar o restante do diploma.

Assim, a aprovação deve ser total, pois são direitos que não comportam divisibilidade, exemplificativamente, não se pode afirmar que o direito à vida esteja desvinculado da liberdade ou da igualdade e, principalmente da dignidade da pessoa humana.

No que tange à denominação de direitos fundamentais, são os direitos humanos tratados em âmbito internacional, tendo recebido status constitucional nacional, ou seja, foram positivados na ordem jurídica interna, tal como os direitos e garantias fundamentais do Título II da Constituição Federal brasileira de 1988.

Esses direitos são (ou deveriam ser) humanos e fundamentais concomitantemente, pois uma determinada sociedade assume a tutela de certos direitos humanos para si, como essenciais ao seu povo. Se essa assunção não decorrer de efeitos meramente tautológicos, tais direitos humanos são

\footnotetext{
${ }^{21}$ DALLARI, Dalmo de Abreu. Direitos humanos e cidadania. São Paulo: Moderna, 1998. p. 7.

22 HERKENHOFF, João Baptista, op. cit., p. 30-31.

23 PIOVESAN, Flávia. Direitos Humanos e o direito constitucional internacional. 9.ed. rev., ampl. e atual. São Paulo: Saraiva, 2008. p. 13.
} 
fundamentais, exercidos de maneira imprescindível e concretamente em um sistema organizado. ${ }^{24}$

De acordo com Robert Alexy um direito fundamental completo é "um feixe de posições de direitos fundamentais". ${ }^{25}$

Esses direitos são analisados conceitualmente a partir da forma, matéria e procedimento. Assim, no sentido formal, visa à delimitação da categoria a qual pertence, já que poderá estar inserido na Constituição ou disposto alhures do rol constitucional. Quanto ao conceito material, objetiva transformar os direitos humanos em direito positivo. Já a concepção procedimental, refere-se a quem cabe a decisão do conteúdo dos direitos fundamentais, seja do constituinte ou do legislador comum. ${ }^{26}$

Luigi Ferrajoli analisa os direitos fundamentais sob a visão formal ou estrutural, como direitos subjetivos direcionados universalmente a todos os seres humanos, independente da capacidade de fato ou de direito; já a ordem subjetiva refere-se a qualquer expectativa positiva (de prestações) ou negativa (de não sofrer lesões). ${ }^{27}$

Os direitos fundamentais cotejados aos direitos patrimoniais apresentam diferenças que os tornam inconfundíveis. Primeiramente, os direitos fundamentais (direito à vida, por exemplo) possuem caráter universal e são voltados à coletividade; enquanto os direitos patrimoniais (direito à propriedade, por exemplo) estão vinculados singularmente a cada titular de forma determinada, excluindo os demais. Além disso, os direitos fundamentais são indisponíveis, inalienáveis, invioláveis, intransigíveis e personalíssimos, enquanto os direitos relacionados à propriedade são disponíveis pela essência, sendo negociáveis e alienáveis. ${ }^{28}$

Há que se observar também a sua estrutura jurídica, à medida que os direitos reais (são predispostos por normas) estão sujeitos às vicissitudes, ou

\footnotetext{
${ }^{24}$ PALOMBELLA, Gianluigi. Dai diritti umani ai diritti fondamentali: sulle conseguenze di una distinzione concettuale. Sociologia del Diritto. Milano, v.31, n.2, p.61-107, 2004. p. 64.

${ }^{25}$ ALEXY, Robert. Teoria dos direitos fundamentais. 5.ed. Trad. Virgílio Afonso da Silva. São Paulo: Malheiros, 2008. p. 249.

${ }^{26}$ BOROWSKI, Martin. La estructura de los derechos fundamentales. Trad. Carlos Bernal Pulido. Bogotá: Universidad Externado de Colombia, 2003. p. 34-37.

${ }^{27}$ FERRAJOLI, Luigi, op. cit., p. 37.

${ }^{28}$ Ibid., p. 46-47.
} 
seja, são criados, modificados ou extintos por atos jurídicos, já os direitos fundamentais (são normas) têm seu título submetido à lei, constituídos por meio de regras gerais, geralmente, constitucionais. Por fim, a estrutura constitucional de direito, isto é, dos direitos patrimoniais são horizontais (formam-se por meio de relações intersubjetivas do tipo civilista - contratual ou sucessório, por exemplo) e dos direitos fundamentais são verticais (construídos por relações publicistas indivíduo com o Estado). ${ }^{29}$

Os direitos fundamentais serão sempre direitos humanos quando analisados sob a perspectiva dos seus titulares, pois todos são seres humanos. Por consequência, se examinados unicamente a partir desse ângulo bastaria simplesmente a utilização do termo "direitos humanos". ${ }^{30}$

Nesse sentido, Ingo Wolfgang Sarlet socorre-se do método da concreção positiva de Antonio Enrique Pérez Luño, segundo o qual os direitos humanos possuem maior amplitude e imprecisão, quando comparados aos direitos fundamentais. Por sua vez, os últimos apresentam características opostas aos primeiros, já que exteriorizam a positivação de preceitos estatais. Todavia, é inegável a correspondência entre os institutos, pela razão de que muitos sistemas constitucionais orientaram-se em diplomas internacionais, sobretudo na DUDH. ${ }^{31}$

Consequentemente, um Estado de direito deve respeitar e cumprir os direitos do homem proclamados nos grandes Pactos e Declarações internacionais. $^{32}$

Quanto à comunicabilidade dos direitos humanos (patamar internacional) e dos direitos fundamentais (âmbito nacional), há muitas discussões acerca da recepção dos tratados internacionais pelo direito interno. Para o Direito Internacional, não cabe analisar como ocorre a receptividade, torna-se relevante

\footnotetext{
${ }^{29}$ FERRAJOLI, Luigi, op. cit., p. 48-50.

${ }^{30}$ SARLET, Ingo Wolfgang. A eficácia dos direitos fundamentais. Uma teoria geral dos direitos fundamentais na perspectiva constitucional. 10.ed. rev., atual. e ampl. Porto Alegre: Livraria do Advogado, 2009. p. 29.

${ }^{31}$ Ibid., p. 31-32.

${ }^{32}$ CANOTILHO, J. J. Gomes. Direito constitucional e a teoria da constituição. 4.ed. Coimbra: Almedina, 2000. p. 233.
} 
apenas saber se houve o cumprimento ou não dos acordos, sem cogitar escusas para o desrespeito. ${ }^{33}$

Além disso, a apreciação advinda do Direito Internacional dos Direitos Humanos tem como ponto nuclear o princípio da interpretação pro homine, ou seja, sempre objetivando a proteção dos homens. ${ }^{34}$

No que diz respeito aos direitos humanos fundamentais, Alexandre de Moraes afirma que:

O conjunto institucionalizado de direitos e garantias do ser humano que tem por finalidade básica o respeito a sua dignidade, por meio de sua proteção contra o arbítrio do poder estatal, e o estabelecimento de condições mínimas de vida e desenvolvimento da personalidade humana pode ser definido como direitos humanos fundamentais. ${ }^{35}$

De acordo com José Afonso da Silva, é tarefa árdua a definição lógica e sintética dos direitos fundamentais do homem também chamados de direitos fundamentais da pessoa humana ou direitos humanos fundamentais. Segundo o autor, merece destaque a denominação derechos humanos ${ }^{36}$ disposta por Antonio Enrique Pérez Luño:

[...] os direitos humanos aparecem como um conjunto de faculdades e instituições que, em cada momento histórico, concretizam as exigências da dignidade, a liberdade e a igualdade humanas, as quais devem ser reconhecidas positivamente pelos ordenamentos jurídicos em nível nacional e internacional. ${ }^{37}$

${ }^{33}$ RAMOS, André de Carvalho. Teoria geral dos direitos humanos na ordem internacional. 2.ed. São Paulo: Saraiva, 2012. p. 222.

${ }^{34}$ Ibid., p. 82.

${ }^{35}$ MORAES, Alexandre de. Direitos humanos fundamentais. Teoria geral. Comentários aos arts. 1ํ a 5 da Constituição da República Federativa do Brasil. Doutrina e jurisprudência. 7.ed. São Paulo: Atlas, 2006. p. 21.

${ }^{36}$ SILVA, José Afonso da. Curso de direito constitucional positivo. 22.ed. rev. e atual. São Paulo: Malheiros, 2003. p. 178. Cumpre mencionar que Alexandre de Moraes compartilha do entendimento de José Afonso da Silva. In: MORAES, Alexandre de, op. cit., p. 22.

${ }^{37}$ PÉREZ LUÑO, Antonio Enrique. Derechos humanos, estado de derecho y constitucion. 8.ed. Madrid: Tecnos, 2003. p. 48. 
No que tange à liberdade sindical, de acordo com a Organização Internacional do Trabalho, os trabalhadores e empregadores:

[...] têm o direito de constituírem organizações da sua escolha, assim como o de nelas se filiarem, com vista a promover e defender os seus interesses, e o direito de negociar colectivamente entre si. Devem poder fazê-lo livremente, sem a ingerência da outra parte ou do Estado. A liberdade sindical é um direito humano fundamental e, conjuntamente com o direito de negociação colectiva, constitui um dos valores fundamentais da OIT. Os direitos de organização e de negociação colectiva são direitos indispensáveis para promover a democracia, uma boa governação do mercado de trabalho e condições de trabalho dignas. ${ }^{38}$

Ante as expressões descritas, a liberdade sindical apresenta-se como um direito humano fundamental, previsto nos principais diplomas internacionais de proteção e reconhecimento da temática humanitária, qual seja a Carta Internacional de Direitos Humanos e outros diplomas do Direito Internacional do Trabalho. Ademais, está inserida no conjunto de direitos e liberdades fundamentais destinado a proporcionar ao homem os requisitos mínimos para que possa usufruir de uma vivência digna.

\subsubsection{Liberdade sindical nas Cartas Internacionais}

O conjunto formado pela Declaração Universal dos Direitos Humanos (1948), o Pacto Internacional sobre Direitos Econômicos, Sociais e Culturais (1966) e o Pacto Internacional sobre Direitos Civis e Políticos (1966) e os seus dois protocolos facultativos (referente ao procedimento de queixa e sobre pena de morte), constituem a denominada Carta Internacional dos Direitos Humanos.

Não obstante, a Carta não se formou imediatamente, a proclamação dos três documentos ocorreu paulatinamente, com um lapso temporal de aproximadamente duas décadas entre a edição da DUDH e dos Pactos.

Essa trilogia não corresponde a um resultado natural e consensual universal acerca da temática humanitária. O processo de elaboração em etapas

\footnotetext{
${ }^{38}$ OIT. Relatório Global de Acompanhamento da Declaração da OIT relativa aos Princípios e Direitos Fundamentais no Trabalho. Liberdade sindical na prática: lições a retirar.

Organização Internacional do Trabalho, Genebra, 2008. p. ix.
} 
da Carta é consequência das concepções divergentes provenientes dos membros da Comissão e da Assembleia Geral da Organização das Nações Unidas. ${ }^{39}$

Primeiramente, quanto à Declaração Universal dos Direitos Humanos, trata-se de uma resolução, portanto, teoricamente, não teria realização vinculada à atuação dos Estados. Entretanto, a proteção dos direitos humanos está em patamar superior a qualquer ordenamento jurídico nacional, uma vez que são direitos supranacionais. Essa transcendência pode ser constatada no excerto:

\footnotetext{
Esse entendimento, porém, peca por excesso de formalismo. Reconhece-se hoje, em toda parte, que a vigência dos direitos humanos independe de sua declaração em constituições, leis e tratados internacionais, exatamente porque se está diante de exigências de respeito à dignidade humana, exercidas contra todos os poderes estabelecidos, oficiais ou não. ${ }^{40}$
}

Sendo assim, os chamados direitos humanos globalizados influenciam na compreensão tradicional de soberania estatal, isto é, na sua relativização e flexibilização, objetivando atribuir aos direitos humanos o efetivo caráter universal. Consoante Flávia Piovesan, a Segunda Guerra Mundial evidenciou um corte nos direitos humanos, por outro lado, o pós-guerra poderia ser interpretado como a reconstrução, representada pela DUDH, assim como pelo apregoamento da universalidade e da indivisibilidade dos relatados direitos. ${ }^{41}$

No que tange aos Pactos, exercem função de complementaridade à DUDH, fazendo com que os direitos elencados recebam força de obrigação jurídica com relação aos entes estatais-partes, os quais se comprometeram voluntariamente e de forma solene à implementação. ${ }^{42}$

Para Dalmo de Abreu Dallari, ambos os Pactos exercem papel de normas internacionais, verdadeiras obrigações políticas meticulosas sobre respeito aos direitos na área da saúde, educação, moradia, reforma agrária e em todos os setores imprescindíveis à existência da vida sob o esteio da dignidade

\footnotetext{
${ }^{39}$ ALVES, José Augusto Lindgren. A arquitetura internacional dos direitos humanos. Coord. Hélio Bicudo. São Paulo: FTD, 1997. p. 25.

${ }^{40}$ COMPARATO, Fábio Konder, op. cit., p. 227.

${ }^{41}$ PIOVESAN, Flávia. Direitos humanos globais, justiça internacional e o Brasil. In: AMARAL JÚNIOR, Alberto; MOISÉS, Cláudia Perrone. O cinqüentenário da declaração universal dos direitos do homem.São Paulo: Universidade de São Paulo, 1999. p. 240.

${ }^{42}$ ALVES, José Augusto Lindgren, op. cit., p. 24.
} 
humana. Além disso, "os países que assinam esses tratados se obrigam juridicamente a respeitá-los e fazer com que sejam cumpridos". ${ }^{43}$

A existência e a divisão dos temas em dois Pactos assentam-se sobre um compromisso diplomático. As potências ocidentais almejavam somente o reconhecimento das liberdades individuais clássicas, ante o poderio estatal na vida privada das pessoas. Por outro lado, o bloco comunista e os países africanos ambicionavam os direitos sociais e econômicos, o que resultou a criação dual. Em dadas passagens, ressalta-se o aspecto de artificialidade, por exemplo, na disposição do direito à autodeterminação dos povos, previsto de forma idêntica no artigo $1^{\circ}$ de ambos os Pactos. ${ }^{44}$

Isso posto, é evidente a importância da Carta Internacional dos Direitos Humanos, a qual está acima de uma mera formalização jurídica. Trata-se da afirmação e reconhecimento dos direitos e liberdades intrínsecos ao homem, seja no aspecto individual e, sobretudo, na vertente coletiva.

Durante a primeira metade do século XX, na Segunda Guerra Mundial (1939-1945) observou-se a ocorrência de diversos crimes contra a humanidade, especialmente, em decorrência da subjugação de um povo sobre o outro, como nas crueldades ocorridas nos campos de concentração. Tais fatos evidenciaram a fragilidade dos sistemas nacionais no que tange ao combate e até mesmo à prevenção acerca da violação dos direitos humanos, seja aquela realizada sobre um grupo ou a pessoas isoladamente.

Tornou-se imprescindível a edição de um documento que afirmasse e reconhecesse os referidos direitos, não uma simples tipificação, houve a necessidade de enfatizar algo que deveria ser evidente: os direitos humanos atrelados ao indivíduo em caráter universal, indivisível e imprescritível, independente da sua localização no globo, ou seja, de alcance transnacional.

Segundo Antônio Augusto Cançado Trindade, houve um desenvolvimento acerca da proteção dos direitos envolvendo a temática em comento, tornou-se compreensível que os direitos básicos do homem não

\footnotetext{
${ }^{43}$ DALLARI, Dalmo de Abreu. Os 50 anos da declaração universal dos direitos do homem e do nascimento de um novo direito. In: SOUZA, Carlos Aurélio Mota de; BUENO, Roberto. 50 anos de direitos humanos. São Paulo: Themis Livraria e Editora, 2003. p. 81.

${ }^{44}$ COMPARATO, Fábio Konder, op. cit., p. 278.
} 
estavam adstritos à atividade estatal por meio da denominada "competência exclusiva". O exclusivismo mostrou-se inadequado no que diz respeito à particularização da soberania, já que não condiz com as relações internacionais. $^{45}$

No entanto, a confecção de um documento de alcance internacional desdobrou-se de forma gradativa.

Durante a sessão do Conselho Econômico e Social das Nações Unidas, em 16 de fevereiro de 1946, concluiu-se que a Comissão de Direitos Humanos desenvolveria suas atividades em três estágios. Primeiramente, a criação de uma declaração de direitos humanos. Em um segundo momento, a organização de um documento com maior força vinculante. E, por fim, a formação de instrumentos capazes de garantir o cumprimento dos direitos humanos, tal como cuidar das possíveis violações. Ante isso, em 18 de junho de 1948 a mencionada Comissão apresentou o projeto da Declaração. ${ }^{46}$

Em 10 de dezembro do mesmo ano, a Declaração Universal dos Direitos Humanos foi adotada e proclamada pela Assembleia Geral das Nações Unidas em Paris, por meio da Resolução 217 A (III), cuja assinatura do Estado brasileiro ocorrera na mesma data.

A proclamação da DUDH teve como objetivo o delineamento de uma ordem pública mundial, estruturada na dignidade da pessoa humana diante da aclamação de direitos básicos. Muito se discutiu sobre a sua aplicabilidade, visto que não é um tratado e se apresenta sob a forma de resolução, apesar disso, possui natureza jurídica vinculante, sendo um dos maiores instrumentos jurídicos e políticos do século $X X{ }^{47}$

A existência de uma força jurídica vinculante pode ser sustentada a partir da corrente defensora da integração ao direito costumeiro internacional, sob os seguintes argumentos: a) a incorporação de afirmações da Declaração nos sistemas constitucionais pátrios; b) a referência das resoluções das Nações Unidas do dever dos Estados em observar a Declaração; c) as

\footnotetext{
${ }^{45}$ TRINDADE, Antônio Augusto Cançado. A proteção internacional dos direitos humanos: fundamentos jurídicos e instrumentos básicos. São Paulo: Saraiva, 1991. p. 04.

${ }^{46}$ COMPARATO, Fábio Konder, op. cit., p. 225.

${ }^{47}$ PIOVESAN, Flávia (2008), op. cit., p. 137-146.
} 
decisões proferidas em sede dos tribunais internos alusivas à Declaração como fonte de direito. ${ }^{48}$

O texto da DUDH consagra em vários artigos e, inclusive no preâmbulo, o respeito aos direitos e liberdade fundamentais relacionados do homem, tais como o direito à vida, proibição da escravidão, não submissão à prática de tortura, assim como a liberdade de ir e vir. Nesse contexto, destaca-se a liberdade de reunião e associação e, consequentemente, a liberdade sindical, dispostas da seguinte maneira:

Artigo XX. 1. Toda pessoa tem direito à liberdade de reunião e associação pacíficas. 2. Ninguém pode ser obrigado a fazer parte de uma associação.

Artigo XXIII. [...] 4. Toda pessoa tem direito a organizar sindicatos e neles ingressar para proteção de seus interesses.

No artigo 20, está compreendida a liberdade de associação, trata-se do gênero, enquanto no artigo 23, há a espécie liberdade sindical (constituir sindicatos e o direito de filiação). Posto isso, verifica-se a elevação da liberdade sindical a status de direito humano, especialmente um direito humano fundamental do trabalhador, previsto também na Constituição Federal brasileira de 1988, apesar da mitigação prescrita pelo diploma constitucional.

Há um tratamento tênue acerca da sindicalização na DUDH, porquanto não caberia a uma Declaração de dimensão geral discorrer detalhadamente sobre tal particularidade. Ademais, meses antes da sua edição, a Organização Internacional do Trabalho adotara a Convenção n. 87 tratando especificadamente sobre a liberdade sindical e a proteção do direito de sindicalização.

A segunda parte referente aos trabalhos da Comissão de Direitos Humanos alude à criação dos Pactos complementares, isto é, a consagração dos direitos previstos na DUDH. O primeiro deles é o Pacto Internacional Relativo aos Direitos Econômicos, Sociais e Culturais, adotado e aberto à assinatura, ratificação e adesão pela Assembleia Geral das Nações Unidas sob a resolução n. 2.200 - A (XXI) de 16 de dezembro de 1966, cujo início da vigência ocorreu em 03 de janeiro de 1976.

${ }^{48}$ PIOVESAN, Flávia (2008), op. cit., p. 144-145. 
No ordenamento jurídico brasileiro, o referido Pacto entrou em vigor em 06 de julho de 1992 sob o Decreto n. 591. Seu preâmbulo ressalta a obrigação da criação de condições que assegurem o acesso das pessoas aos direitos econômicos, sociais e culturais, tal como aos direitos civis e políticos, estruturados na dignidade inerente à pessoa humana. Há destaque também para os deveres de cada indivíduo e aqueles pertencentes às coletividades.

Além disso, há a previsão de outros direitos, tais como: remuneração adequada, associação sindical, nível de vida apropriado para si e a família, alimentação, vestuário e moradia satisfatórios, direito ao trabalho, saúde física e mental, diminuição da mortalidade infantil e previdência social.

O Pacto Internacional Relativo aos Direitos Econômicos, Sociais e Culturais apresenta "roupagem de tratado internacional", visando à obrigatoriedade dos Estados-partes perante a comunidade internacional e, em caso de violação dos direitos elencados, receberão a devida responsabilização. Por isso, observa-se o direcionamento de deveres aos signatários, conforme o uso de expressões como: "os Estados-partes reconhecem o direito de cada um...." 49

Ademais, os países precisam demonstrar o cumprimento de direitos sociais elementares, ainda que haja insuficiência de recursos e a situação econômica seja adversa, pois tais fatos não poderão ser utilizados como empecilhos ao cumprimento dos deveres aceitos. ${ }^{50}$

No que concerne ao direito de associação sindical, o Pacto versou de forma mais detalhada que na DUDH, dedicando o artigo $8^{\circ}$ ao tema. No caput, observa-se a força vinculante atribuída aos Estados assinantes do documento. Em seguida, no item 1, alínea "a", há a exteriorização da liberdade sindical para a fundação e filiação de sindicatos sob a livre escolha do indivíduo, cabendo restrições somente com previsão na legislação e para garantir a segurança nacional ou a ordem pública, ou para proteger os direitos e liberdades alheias.

$\mathrm{Na}$ alínea "b", há a possibilidade dos sindicatos formarem agrupamentos de grau superior, como federações ou confederações nacionais.

\footnotetext{
${ }^{49}$ PIOVESAN, Flávia (2008), op. cit., p. 174.

${ }^{50}$ WEIS, Carlos. Direitos humanos contemporâneos. 2.ed. São Paulo: Malheiros, 2010. p. 102.
} 
Tais instituições poderão desenvolver organizações sindicais em âmbito internacional ou se associar. Às entidades sindicais é garantido o direito de exercício das suas atividades sem qualquer controle, exceto nas limitações legais e imprescindíveis (alínea "c"). O primeiro item é finalizado com o direito de greve conforme as condições legais de cada nação (alínea “d”).

O item 2 faz alusão à limitação dos direitos sindicais previstos no artigo em comento a certas camadas da sociedade, como os membros das forças armadas, da política ou da Administração Pública.

O dispositivo é encerrado com o impedimento aos Estados ratificadores da Convenção n. 87 da Organização Internacional do Trabalho em restringir a liberdade sindical por meio de leis locais (item 3).

Quanto ao Pacto Internacional sobre Direitos Civis e Políticos, aprovado na mesma data que o Pacto Internacional sobre Direitos Econômicos, Sociais e Culturais, teve o início da vigência internacional em 23 de março de 1976. Tendo sido incorporado ao ordenamento nacional sob o Decreto n. 592 de 06 de julho de 1992 e a vigência em 24 de abril do referido ano.

O cotejamento dos Pactos demonstrou repetições, inclusive, com a cópia literal de alguns artigos. Nesse sentido, o art. 1ำ sobre autodeterminação dos povos e 0 art. $5^{\circ}$ sobre a interpretação do Pacto. Todavia, apresenta inovações como o art. 24, dedicado à proteção da criança por parte da família, Estado e sociedade, bem como a aquisição de nacionalidade. No art. 11, a proibição da prisão em decorrência do simples inadimplemento contratual.

Todavia, conforme observado anteriormente, a disposição do conteúdo dos Pactos exclusivamente em um diploma não foi possível em decorrência da ausência de convergência entre os blocos socialistas e capitalistas.

No tocante ao tratamento dispensado ao direito de associação sindical:

\section{Artigo 22}

1. Toda pessoa terá o direito de associar-se livremente a outras, inclusive o direito de construir sindicatos e de a eles filiar-se, para a proteção de seus interesses.

2. O exercício desse direito estará sujeito apenas às restrições previstas em lei e que se façam necessárias, em uma sociedade democrática, no interesse da segurança nacional, da segurança e da ordem públicas, ou 
para proteger a saúde ou a moral pública ou os direitos a liberdades das demais pessoas. O presente artigo não impedirá que se submeta a restrições legais o exercício desse direito por membros das forças armadas e da polícia.

3. Nenhuma das disposições do presente artigo permitirá que Estados Partes da Convenção de 1948 da Organização do Trabalho, relativa à liberdade sindical e à proteção do direito sindical, venham a adotar medidas legislativas que restrinjam - ou aplicar a lei de maneira a restringir - as garantias previstas na referida Convenção.

Diante do excerto, não são verificadas modificações com relação ao texto do Pacto analisado em momento precedente, exceto pela ausência de alusão ao direito de greve. Todavia, é certo que se está diante da reafirmação da liberdade sindical como um direito humano fundamental inerente ao trabalhador.

Quanto à fiscalização sobre o cumprimento dos direitos e deveres abarcados pelo Pacto, $\mathrm{o}$ art. 40 informa que os Estados membros assumem 0 compromisso de envio de relatórios sobre as medidas adotadas para a efetivação, tal como o progresso atingido. Esses documentos serão analisados pelo Comitê de Direitos Humanos, composto por dezoito membros dos Estados-partes (art. 28).

No que concerne à liberdade sindical, os três diplomas componentes da Carta Internacional de Direitos Humanos apresentam-na como uma das liberdades essenciais à preservação da dignidade humana dos atores sociais, seja para constituir autonomamente organizações sindicais ou simplesmente escolher de forma livre a entidade a qual pretende se filiar.

\subsection{Liberdade sindical como direito humano fundamental}

1.2.1 Conceito de liberdade sindical

Em decorrência do seu uso em diversificados períodos da existência da humanidade, a liberdade evolui e ressignifica-se conforme as realidades sociais. Para Montesquieu, "não existe palavra que tenha recebido 
tantos significados e tenha marcado os espíritos de tantas maneiras quanto a palavra liberdade. ${ }^{51}$

O dicionário Houaiss da Língua Portuguesa define a palavra "liberdade" como um grau de independência legítimo que um cidadão, um povo ou uma nação elege como valor supremo. Ademais, trata-se de um "poder que tem o cidadão de exercer a sua vontade dentro dos limites que lhe faculta a lei". No que se refere ao vocábulo "sindical", está relacionado aos sindicatos. ${ }^{52}$

No que tange à órbita trabalhista, Octávio Bueno Magano credita à liberdade sindical "o direito dos grupos profissionais e dos trabalhadores, que os compõem, de promoverem os interesses respectivos". 53

Para Antonio Ojeda Avilés, a liberdade sindical pode ser definida como "el derecho fundamental de los trabajadores a agrupar-se establemente para participar em la ordenación de las relaciones productivas". ${ }^{44}$

Amauri Mascaro Nascimento destaca a liberdade sindical como uma expressão que comporta mais de um sentido. Por exemplo, quando se objetiva a classificação de sistemas de acordo com o ordenamento jurídico nacional, faz-se uso do "método de conhecimento do direito sindical", o qual se manifesta pela liberdade sindical plena, relativa ou sem liberdade sindical. Por outro lado, se o desafio é a proposição de uma resposta para a indagação "que é liberdade sindical", há o desenvolvimento da liberdade como direito de organização e liberdade como direito de atuação, possuindo caráter de complementaridade e integração. ${ }^{55}$

À medida que se almeja a abrangência da liberdade sindical, constatase a concretização da liberdade coletiva (grupos formais ou informais), da liberdade individual (direito de filiação e desfiliação), bem como da liberdade no plano relacional, cuja exteriorização ocorre ante o Estado, empregador ou outros sindicatos. Diante das acepções aventadas, a liberdade sindical "[...] significa

\footnotetext{
${ }^{51}$ MONTESQUIEU, Charles de Secondat. O espírito das leis. Trad. Cristina Murachco. São Paulo: Martins Fontes, 2000. p. 165

${ }^{52}$ HOUAISS, Antônio. Dicionário houaiss da língua portuguesa. Rio de Janeiro: Objetiva, 2009. p. 1175; 1748.

${ }^{53}$ MAGANO, Octávio Bueno. Dicionário jurídico-econômico das relações de trabalho. São Paulo: Saraiva, 2002. p. 138.

${ }^{54}$ OJEDA AVILÉS, Antonio. Compendio de derecho sindical. Madrid: Tecnos, 1998. p. 34.

${ }^{55}$ NASCIMENTO, Amauri Mascaro. Curso de direito do trabalho. 24.ed. São Paulo: Saraiva, 2009. p. $1224-1225$.
} 
mais que liberdade de organizar sindicatos para a defesa dos interesses coletivos mas, também, um princípio de autonomia coletiva que deve presidir os sistemas jurídicos pluralistas." ${ }^{56}$

José de Segadas Vianna ensina que a liberdade sindical possui peculiaridades que se sobrepõe ao indivíduo isolado. Trata-se de uma consequência do direito de associação expresso na Declaração Universal dos Direitos do Homem, bem como em convenções da Organização Internacional do Trabalho, relacionando-se com a garantia de reunião prevista nas Cartas constitucionais dos Estados democráticos. ${ }^{57}$

José Francisco Siqueira Neto explica que a liberdade sindical é um direito político vinculado à história dos movimentos de trabalhadores em prol da expansão do âmbito de participação, cuja finalidade é a "viabilização do aparecimento de sindicatos livres e autônomos em relação ao Estado e à contraparte, no sentido de possibilitar o equilíbrio de poder nas relações de trabalho" ${ }^{58}$

Segundo Gino Giugni, o direito de organizar-se livremente, conforme previsão no ordenamento constitucional italiano, exterioriza-se como um direito público subjetivo de liberdade, visando ao impedimento da ação estatal lesiva ao interesse tutelado. Por isso, a inserção na Constituição corrobora para o estabelecimento de garantias com relação ao Estado. Contudo, essa proteção não é vislumbrada somente pela disposição normativa, há eminente participação das relações intersubjetivas de caráter privado. ${ }^{59}$

Guillermo Cabanellas assevera:

A liberdade sindical constitui espécie de direito de associação para
fins lícitos e pacíficos, geralmente reconhecido a todos os
habitantes de um país, como faculdade de reunir suas forças com as
de seus semelhantes em uma ou mais atividades, mediante a

${ }^{56}$ NASCIMENTO, Amauri Mascaro (2007), op. cit., p. 1225

${ }^{57}$ VIANNA, José de Segadas. Direito coletivo do trabalho. São Paulo: LTr, 1972. p. 47.

${ }^{58}$ SIQUEIRA NETO, José Francisco. Liberdade sindical e representação dos trabalhadores nos locais de trabalho. São Paulo: LTr, 1999. p. 81.

${ }^{59}$ GIUGNI, Gino; CURZIO, P.; GIROFALO, M. G. Direito Sindical. Trad. Eiko Lucia Itioka. Rev. José Francisco Siqueira Neto. São Paulo: LTr, 1991. p. 47. 
criação de organismos coletivos que não visem lucro, constituindo sociedades ou companhias civis ou mercantis. ${ }^{60}$

Para Manuel Alonso Olea, o direito de o trabalhador filiar-se livremente e constituir sindicatos implica a liberdade sindical como princípio organizativo da classe de trabalhadores, trata-se de um gênero mais amplo que reconhece a toda pessoa o direito de associar-se a outras. ${ }^{61}$

J. J. Gomes Canotilho acentua que a liberdade sindical está acima da simples associação perante o Estado:

[...] o acento tónico coloca-se no direito à actividade sindical, perante o Estado e perante o patronato, o que implica, por um lado, o direito de não ser prejudicado pelo exercício dos direitos sindicais e, por outro lado, o direito a condições de actividade sindical (direito de informação e de assembleia nos locais de trabalho, dispensa de trabalho para dirigentes e delegados sindicais, etc). Finalmente, dada sua natureza de organizações de classe, os sindicatos possuem uma importante dimensão política, que se alarga muito para além dos interesses profissionais dos sindicalizados, fazendo com que a liberdade sindical consista também no direito dos sindicatos a exercer determinadas funções políticas. ${ }^{62}$

No ordenamento jurídico brasileiro, o legislador consagrou a liberdade de associação no art. 5ำ, inciso XVII da Constituição Federal, segundo a qual, a qualquer pessoa é permitido associar-se com intuitos lícitos, não se admitindo a de caráter paramilitar.

Nesse sentido, a liberdade de associação é gênero e a liberdade sindical uma espécie, cuja compreensão não se restringe apenas ao aspecto individual, ou seja, no direito de filiação e de organizar sindicatos, estende-se à própria entidade e na autonomia para tomar decisões quanto ao bom funcionamento, por exemplo.

A simples disposição normativa ou jurídica da liberdade sindical é insuficiente para a sua verdadeira efetividade no contexto nacional, faz-se imprescindível garanti-la. Essa garantia somente é vislumbrada em um Estado

${ }^{60}$ CABANELLAS, Guillermo. Compendio de derecho laboral. Buenos Aires: Bibliográfica Omeba, 1968. p. 99

${ }^{61}$ ALONSO OLEA, Manuel. Derecho del trabajo. 6.ed. Madrid: Universidad de Madrid Facultad de Derecho, 1980. p. 399.

${ }^{62}$ CANOTILHO, J. J. Gomes; MOREIRA, Vital. Constituição da república portuguesa anotada. 3.ed. rev. Coimbra: Coimbra, 1993. p. 299-300. 
Democrático de Direito, cuja intervenção seja a mínima possível, necessária apenas para a concretização do princípio liberatório e para a exteriorização dos demais direitos sindicais.

\subsubsection{Normatização da Organização Internacional do Trabalho}

A liberdade sindical está prevista nos principais diplomas internacionais referentes aos direitos humanos fundamentais. No Direito Internacional do Trabalho, observa-se a normatização nas convenções e recomendações aprovadas pela Organização Internacional do Trabalho.

A OIT foi criada após a Primeira Guerra Mundial, em 1919, sendo parte do Tratado de Versalhes. A instituição possui composição tripartite, formada por representantes dos governos, trabalhadores e empregadores.

Segundo o preâmbulo da Constituição da OIT, "a paz para ser universal deve assentar sobre a justiça social". Além disso, há a enumeração exemplificativa de melhorias das condições de trabalho, como a afirmação do princípio de liberdade sindical.

A estrutura orgânica compõe-se da Conferência Internacional do Trabalho, o Conselho de Administração e a Repartição Internacional do Trabalho. Destaca-se o papel da Conferência Internacional do Trabalho como Assembleia Geral (órgão supremo), responsável pela regulamentação internacional do trabalho, bem como os problemas afins, seja por intermédio de convenções, recomendações ou resoluções. ${ }^{63}$

Os fatos propulsores ou etapas motivadoras ao surgimento da Organização Internacional do Trabalho ocorreram anteriormente à assinatura do Tratado de Versalhes em 1919.

As concepções iniciais da legislação trabalhista voltada ao âmbito internacional foram intentadas pelo francês Daniel Le Grand (1783-1859), que

\footnotetext{
${ }^{63}$ SÜSSEKIND, Arnaldo. Direito internacional do trabalho. In: SÜSSEKIND, Arnaldo; MARANHÃO, Délio; VIANNA, Segadas; TEIXEIRA, Lima. Instituições de direito do trabalho. 22.ed. São Paulo: LTr, 2005. v.II. p. 1550.
} 
almejava a promulgação de normas pelos governos europeus para findar as "lutas impiedosas entre os competidores". A disseminação dos seus ideais surgiu por meio de entidades privadas, como nos Congressos Internacionais de Beneficência, cujo objetivo essencial era a adoção de regras em nível global, destinadas à proteção dos trabalhadores; em seguida, adveio a expansão dos movimentos sindicais. ${ }^{64}$

Em 1890, ocorreu a Conferência de Berlim, momento incipiente no qual os países reuniram-se para discutir a normatização trabalhista. Em 1897, realizou-se o "Primeiro Congresso Internacional da Proteção do Trabalho" em Zurique, com enfoque para a aprovação de uma resolução solicitando ao governo suíço a promoção da legislação internacional do trabalho, assim como o convite a várias nações para a criação de uma repartição voltada ao labor. ${ }^{65}$

Antes da concretização de tal objetivo, realizou-se um congresso em Bruxelas (1897). Em 1900, fundou-se a Associação Internacional de Legislação do Trabalho na Suíça, considerada a predecessora da OIT. Contudo, diferenciava-se desta, particularmente, pela ausência de governos na sua estrutura, formada exclusivamente por associações nacionais que poderiam representar os Estados. Apenas três conferências internacionais haviam sido realizadas, quando ocorreu a Primeira Guerra Mundial e pôs fim ao exercício da Associação. ${ }^{66}$

Em 28 de junho de 1919, a assinatura do Tratado de Versalhes pelas potências européias encerrou formalmente a mencionada guerra. No tocante à Parte XIII do documento, versou sobre a criação da OIT como uma instituição atrelada à Liga das Nações; atualmente, uma agência pertencente às Nações Unidas desde 1946.

O texto ${ }^{67}$ do Tratado de Versalhes enfatizou o estabelecimento da paz universal por meio da justiça social. Para tanto, ante as muitas injustiças na seara

\footnotetext{
${ }^{64}$ OIT. AS NORMAS INTERNACIONAIS DO TRABALHO. Manual de educação obreira. Genebra:

Repartição Internacional de Trabalho, 1978. p. 03.

${ }^{65}$ Ibid., p. 04.

${ }^{66}$ Ibid., p. 04-05.

${ }^{67}$ Texto original do Tratado de Versalhes: Whereas the League of Nations has for its object the establishment of universal peace, and such a peace can be established only if it is based upon social justice; And whereas conditions of labour exist involving such injustice, hardship, and privation to large numbers of people as to produce unrest so great that the peace and harmony of the world are imperilled; and an improvement of those conditions is urgently required: as, for
} 
trabalhista, vislumbrou-se a indispensável melhoria das condições, por exemplo, mediante a regulamentação das horas de trabalho, bem como o reconhecimento do princípio da liberdade de associação. Especificamente, o art. 427 dispôs sobre o princípio da liberdade sindical, assim: "The right of association for all lawful purposes by the employed as well as by the employers".

Ainda em 1919, na cidade de Washington, realizou-se a primeira reunião da Conferência da OIT, a qual elegeu o Conselho de Administração e também foi escolhido Albert Thomas como diretor da Repartição Internacional do Trabalho, cargo que ocupou até o seu falecimento em $1932 .{ }^{68}$

Diversamente da mencionada Associação Internacional de Legislação do Trabalho, a OIT traz como características:

[...] é uma pessoa jurídica de direito público internacional, de caráter permanente, constituída de Estados, que assumem, soberanamente, a obrigação de observar as normas constitucionais da entidade e das convenções que ratificam, integrando o sistema das Nações Unidas como uma das suas agências especializadas. A OIT é uma associação de Estados, mas não uma entidade supra-estatal $[\ldots]^{69}$

Ademais, cumpre observar a formação tripartite da OIT nos seus órgãos colegiados (Conferência Internacional do Trabalho, Conselho de Administração e Repartição Internacional do Trabalho), isto é, a participação de representantes de trabalhadores, empregadores, tal como dos governos. Entretanto, essa composição é creditada, principalmente, aos movimentos sindicais sucedidos antes e durante a Primeira Guerra Mundial com o intuito de proteger o trabalho em âmbito internacional. ${ }^{70}$

Observa-se na Constituição da OIT, sobretudo, no texto anexado, advindo da Declaração de Filadélfia (1944), a reafirmação dos princípios

\footnotetext{
example, by the regulation of the hours of work, including the establishment of a maximum working day and week, the regulation of the labour supply, the prevention of unemployment, the provision of an adequate living wage, the protection of the worker against sickness, disease and injury arising out of his employment, the protection of children, young persons and women, provision for old age and injury, protection of the interests of workers when employed in countries other than their own recognition of the principle of freedom of association, the organisation of vocational and technical education and other measures; Disponível em: <http://avalon.law.yale.edu/imt/partxiii.asp.>. Acesso em: julho de 2013.

${ }^{68}$ SÜSSEKIND, Arnaldo. Direito internacional do trabalho. 3.ed. São Paulo: LTr, 2000. p. 107-108.

${ }^{69}$ SÜSSEKIND, Arnaldo. Convenções da OIT. 2.ed. São Paulo: LTr, 1998. p. 19.

${ }^{70}$ lbid., p. 24.
} 
básicos ${ }^{71}$ inerentes à proteção do trabalhador, dos quais se destaca o gênero "liberdade de associação".

Nesse sentido, é inegável a preocupação da instituição com relação à eminência dos direitos humanos fundamentais, por serem "um elemento essencial de toda ação destinada a melhorar a situação dos trabalhadores". ${ }^{72}$ A proteção aos trabalhadores conferida pela OIT promove a universalização e a internacionalização dos direitos humanos, consentâneas à dignidade humana. ${ }^{73}$

Todavia, a disposição genérica do direito associativo nas aludidas Cartas Internacionais mostrou-se insuficiente para garantir a plena liberdade sindical. Por isso, foram adotadas normas específicas para tal finalidade, quais sejam: a Convenção n. 87, Convenção n. 98, Convenção n. 151, assim como a Declaração da OIT sobre os "Princípios e Direitos Fundamentais no Trabalho".

Além das referidas normas com o intuito de assegurar a liberdade sindical, a OIT dispõe do Comitê de Liberdade Sindical, comissão responsável por analisar os casos de violação dos direitos sindicais, por meio de queixas apresentadas pelos governos, bem como pelas entidades representantes dos trabalhadores ou empregadores.

Em 17 de julho de 1948, a Conferência Geral da Organização Internacional do Trabalho reuniu-se em São Francisco para a 31a Sessão, a qual resultou na adoção da Convenção n. 87 sobre "Liberdade Sindical e Proteção do Direito de Sindicalização", cuja vigência ocorreu a partir de 4 de julho de 1950.

Atualmente, a lista de Estados ratificadores do Convênio é de cento e cinquenta e dois ${ }^{74}$, no entanto, países com destaque no cenário mundial ainda não

\footnotetext{
${ }^{71}$ A Constituição da OIT, no seu Anexo, n. I destaca os seguintes princípios fundamentais: a) o trabalho não é uma mercadoria; b) a liberdade de expressão e de associação é uma condição indispensável a um progresso ininterrupto; c) a penúria, seja onde for, constitui um perigo para a prosperidade geral; d) a luta contra a carência, em qualquer nação, deve ser conduzida com infatigável energia, e por um esforço internacional contínuo e conjugado, no qual os representantes dos empregadores e dos empregados discutam, em igualdade, com os dos Governos, e tomem com eles decisões de caráter democrático, visando o bem comum.

${ }_{72}^{7}$ OIT (1978), op. cit., p. 27.

73 PASSOS, André Franco de Oliveira; FRIEDRICH, Tatyana Scheila. Direito internacional e liberdade sindical: da teoria geral à necessidade de aplicação prática. In: NICOLADELI, Sandro Lunard; PASSOS, André Franco de Oliveira; FRIEDRICH, Tatyana Scheila (Org.). 0 direito coletivo, a liberdade sindical e as normas internacionais. São Paulo: LTr, 2013. v. I. p. 25.

${ }^{74}$ Listagem obtida por meio de consulta realizado no endereço eletrônico da Organização Internacional do Trabalho. Disponível em: <http//:www.ilo.org>. Acesso em agosto de 2013.
} 
fazem parte desse rol, por exemplo: Brasil, China, Índia, Nova Zelândia e os Estados Unidos.

$\mathrm{Na}$ época da edição da norma internacional, isto é, fim da Segunda Guerra Mundial, significou uma resposta aos regimes nazista e fascista, especialmente, às organizações sindicais inspiradas no modelo de Benito Mussolini. ${ }^{75}$ Nessas circunstâncias, objetivou-se a proteção dos direitos sindicais de empregados e empregadores por uma norma internacional criada especialmente para tal finalidade, diversamente do aspecto geral trazido pelo Tratado de Versalhes.

Harold Dunning destaca que qualquer trabalhador, seja pertencente ao setor industrial ou da agricultura, por exemplo, poderia compreender o texto, já que os artigos são curtos, pois não há uma linguagem técnica dificultando o entendimento. Além disso, a adoção da Convenção n. 87 repercutiu positivamente para a formulação de elementos que convergiram para a Declaração Universal dos Direitos Humanos. ${ }^{76}$

A aludida Convenção é dividida em quatro partes, quais sejam: Parte I liberdade Sindical; Parte II - Proteção do Direito Sindical; Parte III - Medidas Diversas; Parte IV - Disposições Finais.

$\mathrm{O}$ art. $2^{\circ}$ trouxe a liberdade de fundação de entidades sindicais e a livre associação. Segundo esse dispositivo:

Art. 2 - Os trabalhadores e os empregadores, sem nenhuma distinção e sem autorização prévia, têm o direito de constituir as organizações que estimem convenientes, assim como o de filiar-se a estas organizações, com a única condição de observar os estatutos das mesmas.

Portanto, há que se garantir a constituição de organizações conforme as necessidades profissionais do grupo e a inexistência de regras sobre critérios de filiação e desfiliação, exceto quanto à imprescindibilidade de observar o estatuto da entidade a qual pretenda fazer parte.

\footnotetext{
${ }^{75}$ AROUCA, José Carlos. Quem tem medo da convenção n. 87? Revista LTr: Suplemento Trabalhista, São Paulo, ano 48, n. 155/12, p. 799-805, 2012.

${ }^{76}$ DUNNING, Harold. Orígenes del convenio num. 87 sobre libertad sindical y derecho de sindicación. Revista Internacional del Trabajo, Genebra, v. 117, n. 02, p. 153-166. p. 153.
} 
Consoante o entendimento de Amauri Mascaro Nascimento, é indispensável o estabelecimento da diferenciação entre o direito associativo e a liberdade sindical. No Brasil, por exemplo, sempre foi garantido o direito de associação, conforme dispunha a Constituição Republicana de 1891, bem como nos ordenamentos constitucionais de 1934, 1937 e 1946; mas, a liberdade sindical não ocorreu. Por isso, tal princípio manifesta-se como um "juízo de valor", derivado das concepções entre sindicatos, Estado e outros atores em uma determinada ordem jurídica. ${ }^{77}$

No art. 3ํa a Comissão elaboradora preocupou-se em garantir a liberdade de administração e autonomia interna, visto que dispôs acerca do direito das organizações sindicais elaborarem seus estatutos e regramentos administrativos, escolher os seus representantes e estabelecer a forma e a atuação.

Não se pode olvidar da proibição de qualquer interferência das autoridades públicas que possam mitigar ou obstruir o desempenho das entidades. Outrossim, a aquisição de personalidade jurídica não poderá ser condicionada a meios que possam restringir a liberdade de associação e de administração (art. $7^{\circ}$ ).

A liberdade sindical não está adstrita às entidades de base, poderão ser constituídas federações e confederações; inclusive, admitindo-se a filiação às organizações internacionais de trabalhadores e empregadores, conforme a disposição do art. $5^{\circ}$.

Em vista disso, nota-se a "independência sindical" das organizações frente às autoridades públicas e aos demais setores. Todavia, Octavio Bueno Magano adverte para a utilização da aludida expressão, assim:

\footnotetext{
É comum entre os agentes da OIT referirem-se à Convenção n. 87, como asseguradora de independência sindical. Compreende-se que assim procedam, a fim de dar maior ênfase à Convenção em causa. Contudo, a rigor, o termo não se mostra apropriado, porque conecta-se com a idéia de soberania, própria dos Estados Nacionais, ao passo que a liberdade sindical se traduz em uma mera autonomia, ou seja, poder de auto-regulamentação, contido no âmbito da soberania. ${ }^{78}$
}

\footnotetext{
${ }^{77}$ NASCIMENTO, Amauri Mascaro. Compêndio de Direito Sindical. 7.ed. São Paulo: LTr, 2012. p. 177.

${ }^{78}$ MAGANO, Octavio Bueno. Proposta de emenda constitucional e convenção n. 87 da OIT.

Revista LTr, São Paulo, vol. 63, n. 01, jan. 1999. p. 09.
} 
Data maxima vênia, ao tratar da independência sindical, não se cogita estabelecer comparação com a soberania de qualquer Estado ou limitá-la, apenas ressaltar a atuação autônoma da organização sindical, ou seja, sem intervenções estatais. Além disso, o legislador nacional não poderá, sob determinada razão, prejudicar as garantias previstas na Convenção ratificada por ele (art. $8^{\circ}$ ).

A Parte II da Convenção trouxe somente o art. 11, cuja redação adverte para o compromisso dos membros da Organização Internacional do Trabalho de assegurarem a efetividade do livre exercício do direito sindical, seja dos trabalhadores ou empregadores. No que tange às Partes III e IV, versam acerca de assuntos procedimentais, como renúncia, registro, ratificação e prazos.

Desde a $31^{\text {a }}$ Sessão da Conferência Geral do OIT, ou seja, há mais de meio século, a Convenção n. 87 ainda não foi ratificada pelo Brasil, houve somente um "ensaio" para a aprovação pelo Congresso Nacional.

Em 31 de maio de 1949, durante o governo do Marechal Eurico Gaspar Dutra, iniciou-se o processo para adesão à citada norma. Mas, o progresso foi insignificante, tendo em vista que até 1966, consoante José Carlos Arouca, sua tramitação foi "tortuosa, melhor dizendo vergonhosa", ou seja, não ocorreu. ${ }^{79}$

O mencionado presidente não era considerado um defensor da liberdade sindical, pois executou diversas ações coibindo o exercício dos direitos sindicais, por exemplo: a interferência nas organizações sindicais, 0 fechamento da Confederação dos Trabalhadores do Brasil (CTB), assim como a criminalização do direito de greve (Decreto-Lei n. 9.070/46). ${ }^{80}$

Nesse contexto de entraves, não se pode olvidar do desaparecimento de documentos precípuos à análise pela Câmara dos Deputados. Tal extravio mostrou-se propício a não aprovação da Convenção n. 87, uma vez que o país enfrentava um processo de redemocratização, conquistado com a Constituição de 1946, o que poderia colocar em xeque toda a estrutura sindical baseada no

\footnotetext{
${ }^{79}$ AROUCA, José Carlos (2012), op. cit., p. 799.

80 lbid.
} 
modelo italiano da Carta del Lavoro, cuja manutenção era partilhada por parcela considerável da sociedade. ${ }^{81}$

Ademais, com relação à ausência de ratificação pelo governo brasileiro, são elencados outros fatores de comodidade, como a manutenção da unicidade sindical e da contribuição sindical obrigatória.

Nesses termos, cumpre observar:

No Brasil, exemplos caricatos de conduta anti-sindical praticada pelo Estado são a contribuição sindical compulsória e a unicidade sindical, institutos previstos na Constituição federal em vigor, que ferem a liberdade sindical. Por essa razão, o Brasil ainda não ratificou a Convenção no 87 da OIT, que trata da "Liberdade Sindical e Proteção do Direito de Sindicalização".

Entretanto, a prática da pluralidade sindical em contraponto ao monopólio organizacional, não significa a afirmação absoluta da liberdade sindical. A Convenção n. 87 da OIT aconselha a presença plural de entidades sindicais, desde que resultantes do livre arbítrio das partes interessadas. ${ }^{83}$

Nesse sentido, a simples ratificação da Convenção 87 não é capaz de efetivar a liberdade sindical em sua plenitude, assim como as demais peculiaridades adstritas. Por isso, cumpre observar:

Não bastará aprovar a Convenção n. 87 para conduzir a classe operária ao paraíso ou pelo menos ter um pouco mais de segurança e sindicatos mais fortes e respeitados. Continuará tudo igual se não se aprovar, também, medidas que imponham a democracia sindical, o autocontrole através de um Conselho eleito diretamente pelos trabalhadores, a vedação e punição das práticas antissindicais [...] $]^{84}$

A incorporação da Convenção ao ordenamento brasileiro é apenas um dos elementos necessários, pois não basta garantir, é preciso assegurar meios da

${ }^{81}$ PINTO, Almir Pazzianotto. Convenção 87. Revista de Direito do trabalho. São Paulo, v. 31, n. 119, p. 11-14, jul./set. 2005. p. 11.

82 PINTO, Roberto Parahyba de Arruda. Pela aprovação da convenção o 87 da OIT, pelo

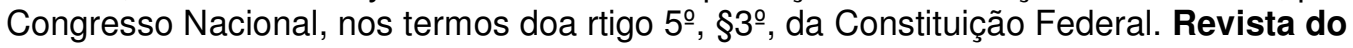

Advogado: AASP, São Paulo, v. 28, n. 97, p. 184-190, maio 2008. p. 189.

${ }^{83}$ MEIRELLES, Davi Furtado. Liberdade sindical: o modelo ideal. LTr: Revista Legislação do

Trabalho. São Paulo, v.74, n.5, p.542-52, maio. 2010. p. 545.

${ }^{84}$ AROUCA, José Carlos (2012), op. cit., p. 804. 
sua efetivação, entre eles: o fortalecimento das organizações sindicais e a concretização verdadeira da representatividade.

Após a 32ª Sessão da Conferência Geral da Organização Internacional do Trabalho, realizada em Genebra, em 1을 de julho de 1949, adotou-se a Convenção n. 98, cujo conteúdo versa sobre o "direito de sindicalização e negociação coletiva". A aprovação pelo Congresso Nacional brasileiro ocorreu em 27 de agosto de 1952 por meio do Decreto Legislativo n. 49. Torna-se eminente destacar que a norma internacional em análise exerce papel de complementaridade em relação à Convenção n. 87.

O Convênio n. 98 visa à proteção contra quaisquer atos considerados antissindicais, especialmente, aqueles que possam impedir o exercício da liberdade sindical relacionado ao emprego, conforme dispõe 0 art. $1^{\circ}$.

Em seguida, são previstas duas hipóteses cuja proteção é imprescindível, quais sejam:

Art. $1^{\circ}[\ldots]$ - 2. Tal proteção deverá, particularmente, aplicar-se a atos destinados a:

a) subordinar o emprego de um trabalhador à condição de não se filiar a um sindicato ou de deixar de fazer parte de um sindicato;

b) dispensar um trabalhador ou prejudicá-lo, por qualquer modo, em virtude de sua filiação a um sindicato ou de sua participação em atividades sindicais, fora das horas de trabalho ou, com o consentimento do empregador, durante as mesmas horas.

Na alínea "a", observa-se a defesa da liberdade de associação, isto é, o empregador ou qualquer instituição não poderão limitar ou condicionar a formação da relação de emprego em decorrência da manifestação de vontade do indivíduo em agregar-se ou não a determinada organização sindical, por exemplo, cláusulas como a closed shop (empresa aberta somente a filiados) e a open shop (a empresa é aberta a não filiados).

Em "b", também se tutela o direito de filiação, visto que o trabalhador não poderá sofrer dispensa ou prejuízos em consequência da participação no cotidiano sindical, desde que não o faça durante o exercício do horário regular de trabalho ou, nessa situação, sem a anuência do empregador. 
Por vezes, a proteção esbarra na dificuldade dos trabalhadores em demonstrar o caráter antissindical das condutas adotadas em seu desfavor, ou seja, a demonstração do real motivo da dispensa ou negativa de contratação, como no estabelecimento de listas negras circulantes entre os empregadores. Por isso, em dadas circunstâncias, torna-se salutar a inversão do ônus probatório, ficando a cargo do empregador demonstrar que a medida aplicada é desconexa às questões sindicais. ${ }^{85}$

Para a plena eficácia do art. 1ํㅡㄹ os órgãos de controle da OIT defendem que não basta a existência de uma legislação nacional que permita ao empregador a dispensa sem justa causa do empregado mediante o pagamento de indenização, pois em dadas circunstâncias, o real motivo é a filiação ou o exercício de atividades sindicais. Por isso, a reintegração do trabalhador dispensado e uma indenização retroativa mostram-se instrumentos adequados para remediar a prática de atos antissindicais. ${ }^{86}$

Tais hipóteses externam apenas rol meramente exemplificativo, outras situações podem ser aventadas. A análise dos casos decididos pelo Comitê de Liberdade Sindical permite a visualização da criatividade negativa dos Estados, empregadores, entidades patronais e de trabalhadores na distorção dos direitos sindicais básicos e a consequente prática antissindical.

No texto da Convenção n. 87 contemplou-se expressamente a impossibilidade de ingerência das autoridades públicas nas organizações sindicais, sejam aquelas formadas por trabalhadores ou empregadores. Por sua vez, a Convenção n. 98 acrescentou o citado impedimento concernente à intervenção de uma agremiação em outra na formação, funcionamento e administração da entidade, diretamente ou indiretamente por intermédio de agentes ou membros (art. $2^{\circ}, 1$.).

Ademais, são elencadas algumas hipóteses que evidenciam a interferência, tais como: ações objetivando a criação de instituições de trabalhadores submetidas ao domínio de empregadores ou organizações patronais; assim como, o fomento aos sindicatos de trabalhadores mediante

${ }^{85}$ GERNIGON, Bernard. El convenio núm. 98 de la OIT: un instrumento que sigue siendo de actualidad cincuenta años después de su adopción. Educacion Obrera. Genebra, v.1/2, n.114/115. p.19-23. 1999. p. 20.

${ }^{86} \mathrm{lbid}$. 
diversificados meios com o intuito de estabelecer a vinculação e dependência ao mencionado controle (art. $2^{\circ}, 2$.).

Diante disso, verifica-se que o empregador é o principal "infrator potencial da liberdade sindical". Outrossim, insere-se a figura do Estado na prática de atos antissindicais, seja na assunção do papel de empregador ou legislador. ${ }^{87}$

Mesmo com a ratificação da Convenção n. 98, não é possível vislumbrar mecanismos eficientes que assegurem a negociação coletiva, pois os artigos da Consolidação das Leis do Trabalho tratam de formalidades relacionadas, por exemplo, ao quorum das assembleias e conteúdo dos acordos, demonstrando inércia quanto ao impulso e estrutura da normatização coletiva. ${ }^{88}$

Nesse contexto, a existência de um sindicato sólido é imprescindível para que a negociação coletiva também possa repercutir em efeitos positivos, visto que uma entidade sindical "apática" não terá a autonomia suficiente para negociar em igualdade com os empregadores.

Tal como a Convenção n. 87, a Convenção n. 98 dispõe ao ordenamento jurídico nacional à aplicabilidade das garantias às forças armadas e à polícia. A ratificação da Convenção por um país signatário, "não deverá ser considerada como devendo afetar qualquer lei, sentença, costume ou acordo já existentes, que concedam aos membros das forças armadas e da polícia garantias previstas pela presente Convenção" (art. 5º).

Durante a 64a reunião da Conferência Internacional do Trabalho, em 1978, na cidade de Genebra, aprovou-se a Convenção n. 151 da Organização Internacional do Trabalho, intitulada "Direito de Sindicalização e Relações de Trabalho na Administração Pública".

Apesar de a sua vigência ter ocorrido em 25 de fevereiro de 1981, somente cinquenta países ratificaram-na. Ademais, a maioria das assinaturas ocorreu a partir da década de noventa ou em momento posterior, como o Estado brasileiro (signatário a partir de 15 de junho de 2010). Nações que desempenham papel de relevo na economia mundial, como os Estados Unidos, Japão e China ainda não adotaram o diploma.

${ }^{87}$ PINTO, Roberto Parahyba de Arruda, op. cit., p. 188.

${ }^{88}$ LOGUERCIO, José Eymard. Pluralidade sindical. Da legalidade à legitimidade no sistema sindical brasileiro. São Paulo: LTr, 2000. p. 143. 
Tendo em vista a participação cada vez mais expressiva da Administração Pública na prestação de serviços, o preâmbulo da aludida norma internacional enfatizou a necessária existência de relações salutares entre as autoridades públicas e as organizações de servidores públicos. A Convenção traz a expressão "empregados públicos", mas a expressão deve ser interpretada pelo modo extensivo, isto é, aplicável a todos os indivíduos que estabeleçam relação trabalhista com os entes públicos.

Além disso, a execução das atividades públicas está incumbida aos seus servidores, ou seja, indivíduos merecedores de garantias e direitos sindicais como os trabalhadores da iniciativa privada. Consequentemente, o Estado adquire a configuração de empregador, dotado de deveres para com seus empregados.

No tocante à consciência brasileira para tais circunstâncias, há o predomínio da morosidade, que não pode ser atribuída unicamente à ratificação extemporânea da Convenção n. 151. A legislação nacional exerceu papel limitador por um longo período, cujo exemplo recorrente é o da Consolidação das Leis do Trabalho de 1943, a qual prevê:

Art. 566 - Não podem sindicalizar-se os servidores do Estado e os das instituições paraestatais.

Tal dispositivo não foi recepcionado pela Constituição Federal de 1988, já que no art. 37, há a previsão do direito à sindicalização dos servidores públicos, assim: "VI - é garantido ao servidor público civil o direito à livre associação sindical”.

No art. $1^{0}$ da Convenção n. 151, acentua-se a aplicação indistinta do diploma internacional para todos os servidores da Administração Pública. Entretanto, em decorrência do princípio da norma mais benéfica, há que se privilegiar o regramento de outras Convenções Internacionais do Trabalho que acarretem disposições mais salutares ao trabalhador.

Em seguida, o art. $2^{\circ}$ dedica consideração especial à legislação nacional dos países subscritores, visto que o ordenamento jurídico interno deverá delimitar em quais circunstâncias as garantias previstas na Convenção 
aplicam-se aos servidores ocupantes de cargo ou funções, cujas atribuições demandem caráter decisório, de direção ou obrigações relacionadas a conteúdo de elevado sigilo.

No tocante às possibilidades de utilização da Convenção para a proteção, o art. 4ำ, 2, enumera duas hipóteses, quais sejam: a) o acesso ao emprego não poderá estar adstrito a não filiação ou à desfiliação; b) a impossibilidade de dispensa ou causa de prejuízos ao empregado em decorrência da sua filiação a uma organização ou participação nas atividades normais.

Tal como as Convenções n. 87 e 98, a Convenção 151 cuida em garantir a independência das organizações (de servidores públicos) em relação às autoridades públicas, bem como aos atos de ingerência na constituição, funcionamento e administração das entidades.

Há que se destacar o uso da negociação coletiva para determinar as condições de emprego e a resolução de conflitos, conforme preceituam os artigos $^{89} 7^{\circ}$ e $8^{\circ}$, respectivamente.

Por fim, o art. 9o garante aos empregados públicos o usufruto dos direitos civis e políticos com a finalidade de exercício da liberdade sindical, salvo para as "obrigações que se derivem de sua condição e da natureza de suas funções".

No início da década de 90, a globalização, o fim da guerra fria e a revolução da tecnologia da informação evidenciaram as transformações sofridas pelo mundo. Nesse contexto, possibilitou-se o estabelecimento de um debate global sobre as normas fundamentais do trabalho, seja no âmbito da OIT ou externamente. Restou evidente que o crescimento econômico não atingiu o

${ }^{89}$ Art. 7. Deverão ser adotadas, sendo necessário, medidas adequadas às condições nacionais para estimular e fomentar o pleno desenvolvimento e utilização de procedimentos de negociação entre as autoridades públicas competentes e as organizações de empregados públicos sobre as condições de emprego, ou de quaisquer outros métodos que permitam aos representantes dos empregados públicos participar na determinação de tais condições.

Art. 8. A solução dos conflitos que se apresentem por motivo da determinação das condições de emprego tratar-se-á de conseguir, de maneira apropriada às condições nacionais, por meio da negociação entre as partes ou mediante procedimentos independentes e imparciais, tais como a mediação, a conciliação e a arbitragem, estabelecidos de modo que inspirem a confiança dos interessados. 
mesmo grau de desenvolvimento em todas as regiões do globo, pois a pobreza não foi erradicada, assim como a injustiça social e a desigualdade. ${ }^{90}$

A Conferência Internacional do Trabalho, em junho de 1998, adotou por maioria absoluta a "Declaração da OIT sobre os Princípios e Direitos Fundamentais no Trabalho".

A análise do art. 1ำ da Declaração não permite a visualização de novas garantias ou regramento de obrigações. Houve a reafirmação dos princípios e direitos previstos na Constituição da OIT e na Declaração de Filadélfia, bem como a adesão livre dos Estados à citada agência da ONU, que os remete à aceitação dos preceitos dispostos nos referidos documentos.

Sendo assim, conforme o art. $2^{\circ}$, ainda que os países membros da OIT não tenham ratificado determinada convenção, possuem o compromisso derivado de obedecer e promover os princípios relativos aos direitos fundamentais que são objetos desses convênios, quais sejam:
a) a liberdade sindical e o reconhecimento efetivo do direito de negociação coletiva;
b) a eliminação de todas as formas de trabalho forçado ou obrigatório;
c) a abolição efetiva do trabalho infantil; e
d) a eliminação da discriminação em matéria de emprego e ocupação

No tocante à alínea "a", disposto de forma especial pelas Convenções n. 87, 98 e 151 e outros diplomas internacionais, a liberdade sindical plena é condição para a efetiva negociação coletiva; por conseguinte, sua mitigação restringe o acesso eficaz aos meios de resolução de conflitos na seara dos direitos sindicais. Não obstante, nações (signatárias da OIT), sob o pretexto da não ratificação de certos convênios ou por meio da sua interpretação particular, permanecem desrespeitando princípios basilares.

Em 1998, quando foi adotada a Declaração sobre "Princípios e Direitos Fundamentais no Trabalho" , Hilary Kellerson (Ex-Conselheira Adjunta da OIT),

\footnotetext{
${ }^{90}$ OIT. Declaración. Antecedentes. Disponível em:

$<$ http://www.ilo.org/declaration/thedeclaration/background/lang--es/index.htm> Acesso em: agosto de 2013.
} 
ressaltou a importância da união do progresso social ao crescimento econômico, visando à promoção das normas fundamentais do trabalho e dos seus princípios subjacentes. Consoante a Conselheira, somente "el passo del tiempo permitirá apreciar todo el valor de este documento, que dependerá de la aplicación activa del seguimiento por muchos agentes, dentro y fuera de la OIT". 91

Decorrida uma década da aprovação da Declaração sobre "Princípios Fundamentais no Trabalho", a OIT publicou um estudo denominado "Liberdade sindical na prática: lições a retirar". Trata-se de um relatório global de acompanhamentos da citada Declaração.

Segundo o relatório, apesar do aumento de ratificações das principais convenções sobre liberdade sindical, é preciso desenvolver ações que promovam a "ratificação universal". Ademais, metade da população ativa total dos Estados membros da OIT vive em cinco países que não aderiam ao Convênio n. 87 (o principal sobre a temática), quais sejam: Brasil, China, Índia, República Islâmica do Irã e os Estados Unidos. ${ }^{92}$

O estudo acentuou ser incomum a proibição total de organizações de trabalhadores ou empregadores na atualidade. Além disso, verificou-se um progresso no que diz respeito à extinção dos monopólios sindicais sob o controle estatal; entretanto, esse ambiente ainda prospera em países cujo poder político é exercido por partido único e atrelado aos "atores do mundo do trabalho". ${ }^{93}$

As violações da liberdade sindical tornaram-se sutis, mas continuam propagando efeitos danosos, como a existência de discricionariedade para a concessão e autorizações referentes à constituição e funcionamento de entidades sindicais. Para tanto, apontou-se no relatório a necessidade de garantir a total independência e liberdade das organizações, seja por meio do impedimento de ingerência das autoridades públicas ou das agremiações entre si. ${ }^{94}$

De acordo com os órgãos de controle da OIT, houve aumento das queixas por atos antissindicais, especialmente, os casos envolvendo dispensas,

\footnotetext{
${ }^{91}$ KELLERSON, Hilary. La declaracion de la OIT de 1998 sobre los principios y derechos fundamentales: un reto para el futuro. Revista Internacional del Trabajo, Ginebra, v.117, n.2, p.2438, 1998. p. 248.

${ }_{92}$ OIT ( 2008), op. cit., p. 06.

${ }^{93}$ Ibid., p. 11.

${ }^{94}$ Ibid., p. 9 e 11.
} 
destituição de promoções, transferências e recusas em contratar, inclusive pela administração pública quando investida no posto de empregador. Para evitar essas condutas, é indispensável a introdução de sanções e vias de recurso que impossibilitem a prática nociva, pois a legislação ainda se mostra incipiente. ${ }^{95}$

A proteção sindical não está adstrita às relações trabalhistas tradicionais, pois o mercado de trabalho contemporâneo descortinou novos vínculos. Muitos desses postos de trabalho são criados de maneira precária e mediante condições lesivas ao trabalhador. Isto posto, esse cenário necessita da ação efetiva dos sindicatos para a promoção do emprego de forma digna, por meio dos princípios e direitos relacionados à liberdade sindical e à negociação coletiva. ${ }^{96}$

O Comitê de Liberdade Sindical identificou avanços no que se refere à aplicação dos referidos princípios, tais como a diminuição das queixas sobre a privação das liberdades civis. Por outro lado, alguns entraves continuam dificultando o exercício pleno dos direitos sindicais, quais sejam: dispensas coletivas, prisões, casos de violência (homicídios de sindicalistas, por exemplo), restrições à liberdade de organização e filiação, ingerência do Estado e de terceiros, negociação coletiva limitada, discriminação de trabalhadores sindicalizados e supressão do direito de greve. ${ }^{97}$

Apesar da realidade particular de cada país, os peritos independentes frisaram a imprescindibilidade de observar elementos básicos para a promoção dos princípios e direitos fundamentais:

a) a interligação dos quatro princípios e direitos fundamentais no trabalho, que, na prática se reforçam mutuamente, e o papel chave da liberdade sindical nesta matéria;

(b) a necessidade de avaliar, simultaneamente, a legislação e a prática e dos parceiros sociais, em particular os governos, resolverem os problemas de aplicação desses princípios e direitos;

(c) a necessidade de promover a ratificação das convenções (n. 87) e (n. 98), que correm o risco de passar para segundo plano em relação a outras convenções fundamentais;

(d) a necessidade de uma maior cooperação técnica para ajudar a concretizar os princípios e direitos fundamentais no trabalho de forma integrada, no âmbito dos Programas Nacionais para o Trabalho Digno;

\footnotetext{
${ }^{95}$ OIT (2008), op.cit., p. 12.

96 lbid., p. 24.

97 Ibid., p. 10-11.
} 
(e) a necessidade de formação e do reforço das capacidades para permitir às organizações de empregadores e trabalhadores promoverem eficazmente os direitos fundamentais, participarem na totalidade do processo de implementação e partilharem experiências bem sucedidas;

(f) a necessidade de dedicar uma atenção particular a determinados setores de atividade e categorias de trabalhadores e empregadores e de alargar os direitos de liberdade sindical e negociação coletiva àqueles que deles ainda não beneficiem. ${ }^{98}$

No que se refere à interligação dos quatro princípios e direitos fundamentais, apesar dos avanços, mostra-se empreendimento árduo e vagaroso, uma vez que existe a dificuldade de conscientização unitária. Estados membros não ratificaram os diplomas internacionais referentes à liberdade sindical e insistem na sua aplicação velada, ainda que sejam signatários da Carta Internacional dos Direitos Humanos.

O segundo elemento mencionado pelo relatório está diretamente relacionado à atuação estatal, isto é, a atuação do Estado como gestor no favorecimento de condições propícias ao desenvolvimento dos direitos sindicais de associação. Contudo, não se pode confundir tais práticas com ingerência, pois em dadas ocasiões, o ente estatal revestido na figura do legislador comete inúmeras violações antissindicais.

No tocante à ratificação universal das Convenções, o Convênio n. 87 enseja maior apreensão, visto que somente cento e cinquenta dois países membros realizaram a assinatura, enquanto trinta e três abstiveram-se. Quanto ao diploma n. 98, apenas vinte e dois Estados não o aceitaram, apesar de alguns nomes serem de relevância internacional, como os Estados Unidos, a China e o Canadá.

Quanto aos itens das alíneas "d", "e" e "f", cabe destacar a necessidade de uma atuação interligada das entidades sindicais visando à promoção dos direitos fundamentais.

${ }^{98}$ OIT (2008), op. cit., p. 81-82. 


\subsection{Dimensões da liberdade sindical}

O vocábulo "dimensão" envolve a grandeza ou o alcance de algo. No que tange à liberdade sindical, a doutrina trabalhista brasileira e estrangeira não são uníssonas quanto à forma e nomenclatura da sua exteriorização.

De acordo com Túlio de Oliveira Massoni, "a liberdade sindical é uma liberdade complexa não só em relação aos seus conteúdos mas também em seus objetivos e manifestações potenciais, que são múltiplos e, em diversos momentos históricos, podem se contrapor à própria ordem jurídica" ${ }^{99}$

Amauri Mascaro Nascimento contempla o estudo da temática dividindoa em liberdade de associação, liberdade de organização, liberdade de administração, liberdade de exercício das funções e liberdade de filiação sindical. ${ }^{100}$

Mozart Victor Russomano apresenta a liberdade sindical sob a forma de um triângulo jurídico, composto por partes distintas (sindicalização livre, autonomia e pluralidade sindical) e comunicantes entre si por meio das suas extremidades. Assim, "a liberdade sindical pressupõe a sindicalização livre, contra a sindicalização obrigatória; a autonomia sindical, contra o dirigismo sindical; a pluralidade sindical, contra a unicidade sindical". ${ }^{101}$

Mauricio Godinho Delgado discorre acerca do princípio de associação, desdobrando-o em liberdade de associação e liberdade sindical. Inicialmente, apresenta os caracteres gerais do direito associativo, estruturado no artigo $5^{\circ}, \mathrm{XX}$, da Constituição Federal. Em seguida, direciona o estudo do sindicalismo sob o manto da liberdade sindical por meio das cláusulas de sindicalização forçada, as práticas antissindicais e as garantias da atuação sindical. ${ }^{102}$

Orlando Gomes e Elson Gottschalk analisam a liberdade sindical sob três aspectos: o individual, como a liberdade de aderir a um sindicato ou a liberdade de não se filiar; o coletivo, como a liberdade de fundar um sindicato

\footnotetext{
${ }^{99}$ MASSONI, Túlio de Oliveira. Representatividade sindical. São Paulo: LTr, 2007. p. 76.

100 NASCIMENTO, Amauri Mascaro (2012), op cit., p. 35.

${ }^{101}$ RUSSOMANO, Mozart Victor. Princípios gerais de direito sindical. 2.ed. ampl. e atual. Rio de Janeiro: Forense, 1995. p. 65.

${ }^{102}$ DELGADO, Mauricio Godinho. Curso de direito do trabalho. 12.ed. São Paulo: LTr, 2013. p. 1343-1347.
} 
ou liberdade de determinar o quadro sindical na ordem profissional e territorial; e quanto ao Poder Público, no que diz respeito à independência do sindicato em relação ao Estado ou o conflito entre a autoridade do Estado e a ação sindical, por exemplo. ${ }^{103}$

Nesse sentido, Antonio Ojeda Avilés discorre acerca da liberdade sindical individual voltada ao impedimento de violações estatais, da ingerência patronal, assim como dos ataques aos trabalhadores individualmente. Outrossim, há a análise sob o âmbito coletivo que repercute na organização das entidades, por exemplo, nos sindicatos sem registro. ${ }^{104}$

Ante tais observações sublinha-se a liberdade sindical a partir dos seus aspectos individuais e coletivos; em seguida, os seus desdobramentos, como a liberdade individual de organização e a liberdade coletiva de fundar um sindicato, por exemplo.

\subsubsection{Liberdade sindical individual}

A liberdade sindical individual possui duas vertentes, quais sejam: 0 aspecto positivo da liberdade de associação e o aspecto negativo da liberdade. $O$ primeiro está relacionado à faculdade de aderir a um sindicato, enquanto o segundo à liberdade de não se filiar ou de desfiliação. ${ }^{105}$

O êxito de tais prerrogativas está sujeito à atuação dos sindicatos, do Estado e dos empregadores. No que diz respeito às entidades sindicais, deverão restringir seu labor ao conteúdo profissional ou econômico, portanto, não contempla o foro íntimo ou os direitos individuais de cada associado. ${ }^{106}$

Por outro lado, não há impedimentos à normatização estatutária acerca de limitações gerais, como a proibição simultânea de filiação a mais de uma organização. Contudo, se essa medida fosse engendrada pelo Poder Público,

\footnotetext{
${ }^{103}$ GOMES, Orlando; GOTTSCHALK, Elson. Curso de direito do trabalho. 17.ed. atual. por José Augusto Rodrigues Pinto e Otávio Augusto Reis de Sousa. Rio de Janeiro: Forense, 2005. p. 544. ${ }_{104}$ OJEDA AVILÉS, Antonio, op. cit., p. 38-58.

105 GOMES, Orlando; GOTTSCHALK, Elson, op. cit., p. 544-545.

${ }^{106}$ NASCIMENTO, Amauri Mascaro (2012), op. cit., p. 43-44.
} 
caracterizaria evidente violação à liberdade sindical, visto que resultaria em entremetimento nas ideologias, no funcionamento e nas decisões do sindicato. ${ }^{107}$

Quanto à liberdade de filiação e o Estado, há repercussão especial no campo das proibições, como a filiação de sindicatos às organizações internacionais ou a impossibilidade de associação de determinadas categorias. $^{108}$ No Brasil, a Constituição Federal garante ao servidor público civil o direito à livre associação sindical (art. 37, VI), diversamente do que ocorre em outros países; entretanto, veda-se a sindicalização e o direito de greve aos militares (art. 142, IV).

Relativamente à ingerência estatal, verifica-se em todo o processo de sindicalização, especialmente, pelo uso de mecanismos desalentadores à formação inicial dos sindicatos, como ocorre na proclamação forçada de uma organização representativa, favorecendo-a e discriminando as demais, consequentemente, minando a criação de outras organizações a partir do seu nascimento. ${ }^{109}$

Já a liberdade de filiação frente aos empregadores almeja o combate de certas práticas que condicionariam a oferta de emprego e a sua manutenção, tais como a filiação obrigatória, a renúncia ao direito de associação ou a inscrição em determinada organização. ${ }^{110}$

Nesse sentido, a doutrina enumera cláusulas sindicais prejudiciais ao direito de sindicalização como: a closed shop (empresa fechada a não sindicalizados), open shop (a empresa é aberta a não filiados), yellow dog contract (o empregado assume o compromisso de não se filiar), company union (criação de sindicatos fantasmas), unions shop (compromisso de sindicalizarse), preferencial shop (preferência de admissão a filiados) e label (marca do sindicato nos produtos do empregador para demonstrar a existência da sindicalização na empresa). ${ }^{111}$

\footnotetext{
${ }^{107}$ VILLAVICENCIO RIOS, Alfredo. A liberdade sindical nas normas e pronunciamentos da OIT. Trad. Jorge Alberto Araujo. São Paulo: LTr, 2011. p. 36.

${ }^{108}$ NASCIMENTO, Amauri Mascaro (2012), op. cit., p. 44.

109 OJEDA AVILÉS, Antonio (2012), op. cit., p. 39.

${ }^{110}$ MANGLANO, Carlos Molero. Derecho sindical. Madrid: Dykinson, 1996. p. 263.

${ }^{111}$ NASCIMENTO, Amauri Mascaro (2012), op. cit., p.180.
} 
Consoante Mauricio Godinho Delgado, essas cláusulas denominadas de segurança sindical ou de sindicalização forçada estabelecem um embate entre a liberdade individual (filiação ou desfiliação) e o fortalecimento sindical, o qual é sobreposto em alguns ordenamentos, isto é, a liberdade do grupo profissional superior à liberdade individual. ${ }^{112}$

No tocante à liberdade sindical individual negativa, ou seja, de não se filiar a um sindicato ou de se desfiliar, José Carlos Arouca a sublinha como "a ausência de impedimentos, há liberdade negativa no interior de uma coletividade se cada um puder agir como melhor lhe convier". ${ }^{113}$

Para Luciano Martinez, essa faceta garante ao trabalhador ser "indiferente" às atividades sindicais e mesmo contrariando os princípios de solidarismo deve ser respeitada. ${ }^{114}$ Segundo Mozart Victor Russomano, a prerrogativa de sindicalização livre não confere nenhum efeito sancionatório, ao passo que a sindicalização obrigatória refuta o direito individual, seja por ato direto do Estado ou indiretamente pelos obreiros. ${ }^{115}$

Carlos Molero Maglano desdobra o direito de filiação em: filiar-se, no sentido de evitar atos que impeçam o exercício efetivo de filiação; escolher a organização sindical a qual se pretende filiar; o direito de nova filiação à entidade a qual pertencia; o direito de alterar a instituição a qual é filiado; e o direito de dar baixa ou renunciar à filiação. ${ }^{116}$

Antonio Ojeda Avilés atribui à liberdade individual quatro conteúdos: a liberdade constitutiva, permissiva ao trabalhador fundar um sindicato com seus pares; a liberdade de filiação (positiva e negativa), a qual oportuniza o ingresso a uma organização de livre escolha ou a opção de não se filiar; e a liberdade de participação no cotidiano sindical, porquanto não seria suficiente a criação e filiação se a classe dos trabalhadores não participasse das decisões, eleições e demais atos sindicais. ${ }^{117}$

\footnotetext{
${ }^{112}$ DELGADO, Mauricio Godinho, op. cit., p. 1345.

${ }^{113}$ AROUCA, José Carlos. Curso básico de direito sindical. São Paulo: LTr, 2006. p. 71.

${ }^{114}$ MARTINEZ, Luciano. Condutas antissindicais. São Paulo: Saraiva, 2013. p. 310-311.

${ }^{115}$ RUSSOMANO, Mozart Victor, op. cit., p. 67.

${ }^{116}$ MANGLANO, Carlos Molero, op. cit., p. 263.

117 OJEDA AVILÉS, Antonio, op. cit., p.38-39.
} 
Dessa forma, a liberdade de constituição em conjunto com a liberdade positiva formam a estrutura básica da liberdade sindical (direito) e estão dispostas nos principais diplomas internacionais, enquanto a liberdade negativa e a participação derivam da experiência sindical e tendem a evitar abusos, estando previstas nos ordenamentos internos. ${ }^{118}$

\subsubsection{Liberdade sindical coletiva}

A liberdade sindical coletiva em sentido oposto à individual, não pretende a garantia de direitos sindicais a cada uma das pessoas envolvidas de forma exclusiva. Trata-se do firmamento e manutenção do grupo, por meio da exteriorização das liberdades (direitos) de associação, organização, administração e do exercício de funções. Atrelado ao estudo da liberdade sindical coletiva, deve ser considerado o princípio da autonomia privada coletiva ou autonomia sindical.

Amauri Mascaro Nascimento dividiu a autonomia coletiva em: autonomia organizativa (elaboração de estatutos); autonomia negocial (pactuação de convenções e acordos coletivos de trabalho); autonomia administrativa (eleição da própria diretoria e administração); e autotutela (meios para solucionar os conflitos trabalhistas). ${ }^{119}$

No entendimento de Ronaldo Lima dos Santos a autonomia coletiva consiste no:

[...] poder jurídico conferido a determinados grupos sociais de criar normas jurídicas para a tutela de interesses de uma coletividade, comunidade ou classe de pessoas globalmente consideradas. [...] Sua concepção baseia-se na percepção social da existência de uma lacuna entre a norma geral e a particular, entre a abstração das normas gerais estatais e a excessiva concretude e singularidade das situações particulares (hiperespecíficas) cujo preenchimento dá-se pela esfera contratual coletiva. ${ }^{12}$

\footnotetext{
${ }^{118}$ OJEDA AVILÉS, Antonio, op. cit., p.39.

${ }_{119}^{19}$ NASCIMENTO, Amauri Mascaro (2007), op. cit., p. 1224.

120 SANTOS, Ronaldo Lima dos Santos. Teoria das normas coletivas. São Paulo: LTr, 2007. p. 123.
} 
Embora a autonomia sindical conceda livre exercício às organizações, tal princípio não possui alcance amplo e absoluto. De acordo com Mozart Victor Russomano, há que se observar a segurança interna dos países e a ordem pública. Isso significa que as entidades estariam sob vigilância com relação ao atendimento dos fins legais e estatutários, para evitar desvios funcionais, como objetivos políticos ou a apropriação do patrimônio dos sindicatos. ${ }^{121}$

A autonomia e a liberdade sindical estabelecem uma relação de complementaridade. Ademais, a autonomia coletiva externa múltiplas liberdades e é "estruturada diante da vontade majoritária do grupo, numa relação livre do conjunto de trabalhadores ou empregadores". ${ }^{122}$

Inicialmente, há a liberdade de associação ou liberdade de fundar um sindicato. Os grupos possuem o direito de criar suas organizações sindicais, desde que atendida à legislação do Estado. Mas, não basta a simples afirmação de livre constituição, há que se extirpar obstáculos (formalidades) e permitir aos grupos de trabalhadores e empregadores a formação de suas entidades, demonstrando que "a simplicidade das regras de forma é nota marcante de liberdade". ${ }^{123}$

Nesse sentido, o sindicato como entidade privada possui discricionariedade para realizar tudo aquilo que a norma legal não atribua valor ilícito ou proibido, diversamente dos entes públicos, cuja atuação está adstrita aos comandos legais.

Em vista disso, a necessidade de depósito dos estatutos ou o registro sindical não podem ser entendidos como uma condição imperiosa ou em oposição aos preceitos contidos na Convenção n. 87 da OIT. A arbitrariedade ficará caracterizada no caso concreto apenas quando a faculdade estiver revestida de anuência ou discricionariedade por parte da autoridade competente. ${ }^{124}$

No tocante à liberdade de determinar o quadro sindical na ordem profissional e territorial (típica de países onde o sindicalismo é livre), refere-se à faculdade das entidades sindicais escolherem os critérios de agrupamento,

\footnotetext{
${ }^{121}$ RUSSOMANO, Mozart Victor, op. cit., p. 72-73.

122 AROUCA, José Carlos (2006), op. cit., p. 78.

123 GOMES, Orlando; GOTTSCHALK, Elson, op. cit., p. 549.

124 SIQUEIRA NETO, José Francisco, op.cit., p. 101.
} 
como a formação da categoria, sem que haja o estabelecimento prévio do quadro de atividades e profissões decorrente de norma legal ou de autoridade. Consequentemente, permite-se a existência de diversas organizações sindicais pertencentes ao mesmo ofício ou grupo. Há que se considerar também a possibilidade do estabelecimento de agrupações mais amplas, seja em âmbito nacional ou internacional, como $o$ direito de constituir federações $e$ confederações, bem como a permissão de a elas se filiarem (Liberdade de estabelecer relações entre sindicatos para formar agrupações mais amplas). ${ }^{125}$

A liberdade de constituir uma federação encontra limitação nas legislações que exigem número mínimo de sindicatos ou federações para constituir organizações de grau superior. Além disso, para a efetividade da liberdade de federação há que se respeitar as demais liberdades, individuais positivas ou negativas, bem como a garantia de proteção adequada à liberdade de regulamentação, eleição de representantes, de gestão e a impossibilidade de dissolução ou suspensão mediante atos da administração pública. ${ }^{126}$

Quanto à liberdade de administração, os sindicatos possuem autonomia para o gerenciamento dos próprios atos, seja para suas atividades interiores (autarquia interna) ${ }^{127}$, como a redação dos próprios estatutos, assim como para a impossibilidade de interferência de terceiros (autarquia externa), garantindo-Ihe, por exemplo, a forma de escolha dos seus dirigentes e a fixação de contribuições. ${ }^{128}$ Além da capacidade de organização interna, a liberdade de gestão também se apresenta externamente, garantindo o direito de negociação

\footnotetext{
${ }^{125}$ GOMES, Orlando; GOTTSCHALK, Elson, op. cit., p. 550.

${ }^{126}$ MANGLANO, Carlos Molero, op. cit., p. 277-278.

127 Ericson Crivelli individualiza a democracia sindical (espécie) a partir da definição de Noberto Bobbio acerca de democracia (gênero). Nesse sentido, a democracia sustenta-se na participação dos pertencentes à coletividade nas decisões, assim como pela observância de regras (primárias ou fundamentais) definidoras do procedimento de tomada de decisões e dos legitimados a fazerem uso delas. Por outro lado, o conceito de democracia sindical pode ser dividido em dois sentidos: interno e externo. Desse modo, o sentido interno da democracia sindical é voltado à dinâmica interior das organizações sindicais e manifesta-se, por exemplo, nos procedimentos decisórios e nos seus regramentos. No que diz respeito ao sentido externo, trata-se da exteriorização da atuação sindical, ou seja, a ação dos sindicatos direcionada ao mundo exterior, principalmente diante dos empregadores e das autoridades em geral em prol do debate democrático acerca de assuntos variados, com destaque para a normatização coletiva de trabalho. O autor observa que houve uma democratização nos procedimentos decisórios, ora pela existência formal das liberdades clássicas ora pela existência de facções de oposição contestadora à direção sindical. In: CRIVELLI, Ericson. Democracia sindical no Brasil. São Paulo: LTr, 2000. p. 42; 47; 48; 189.

${ }^{128}$ NASCIMENTO, Amauri Mascaro (2012), op.cit., p. 39-40.
} 
coletiva, o exercício de greve e cuidado com os conflitos de trabalho individuais ou coletivos. ${ }^{129}$

No que tange à liberdade de exercícios de funções, trata-se da maneira segundo a qual as organizações sindicais exercem a representatividade do grupo, conforme os preceitos para os quais se formaram. Essa atuação sindical implica a atuação individual e coletiva, seja diante do Estado, da classe patronal ou de outros órgãos, exprimindo vontades e reivindicações dos seus representados. ${ }^{130}$

Existem muitas funções elencadas à atividade de um sindicato: como a função regulamentar, a qual the possibilita a elaboração de normas coletivas com o intuito de disciplinar as relações individuais de trabalho; a função arrecadatória, cuja faculdade permite a imposição de contribuições aos membros pertencentes à categoria. Porém, tais prerrogativas serão discutidas com maior contorno em momento específico, o qual se discorrerá a respeito da organização sindical brasileira.

${ }^{129}$ MANGLANO, Carlos Molero, op. cit., p. 274-275.

${ }^{130}$ NASCIMENTO, Amauri Mascaro (2012), op.cit., p. 40-41. 


\section{CAPÍTULO 2 ANÁLISE CRÍTICA DA ORGANIZAÇÃO SINDICAL BRASILEIRA À LUZ DOS DIREITOS HUMANOS FUNDAMENTAIS}

\subsection{Organizações sindicais: institutos semelhantes}

A origem dos sindicatos ${ }^{1}$, aos moldes contemporâneos, não é totalmente pacífica no mundo jurídico, há quem remeta a períodos anteriores a

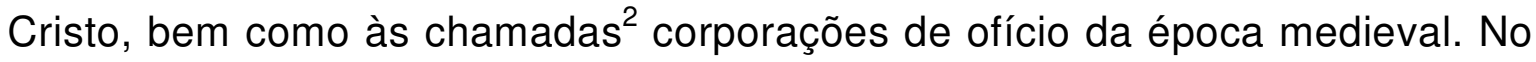
entanto, tais períodos expõem apenas alguns traços do que hoje se entende como entidade com propósitos de defender os interesses da classe trabalhadora ou de empregadores.

Os primeiros sinais do sindicalismo ocorreram em meados da primeira Revolução Industrial. Para tanto, faz-se imprescindível apontamentos de alguns momentos históricos.

Inicialmente, percorrem-se os colégios romanos, criados por Numa e formalizados no reinado de Servio Tulio. Os colégios eram divididos em: a) collegia compitalitia, de cunho religioso; b) collegia artificum vel opificum, de

\footnotetext{
${ }^{1}$ De acordo com a história do Direito Coletivo do Trabalho, o sindicalismo percorreu três fases evolutivas. A primeira é a fase de proibição, marcada pela criminalização do direito de associação profissional, especialmente pela extinção das corporações de ofício e aprovação da lei francesa Le Chapelier. Em seguida, ocorreu a fase de tolerância, Mauricio Godinho Delgado explica que pode ser vista como uma "fase de transição, em direção ao pleno reconhecimento do direito de livre associação e de auto-organização dos sindicatos". In: DELGADO, Mauricio Godinho. Curso... op. cit., p. 1391. Para Amauri Mascaro Nascimento, "a fase da afirmação das associações de trabalhadores iniciou-se quando o Estado resolveu revogar as leis penais que puniam a associação dos trabalhadores e, numa segunda etapa, decidiu aprovar leis que autorizaram o direito de associação sindical". In: NASCIMENTO, Amauri Mascaro. Compêndio..., op. cit., p. 43. Por fim, a fase de reconhecimento jurídico, consoante Ronaldo Lima dos Santos: "[...] pela integração das entidades sindicais nos ordenamentos jurídicos de diversos países; seja pela consagração do direito de associação, em sentido amplo, e nesse, incluídas as formações sindicais; seja, especificadamente, pela previsão do direito de associação profissional e constituição de sindicatos. [...] A introdução dos sindicatos nos ordenamentos jurídicos não foi uma graciosidade do Estado, mas uma mudança de postura deste em face da força com a qual o sindicalismo foi integrando-se na vida social". In: SANTOS, Ronaldo Lima dos Santos. Sindicatos e ações coletivas. Acesso à justiça, jurisdição coletiva e tutela dos interesses difusos, coletivos e individuais homogêneos. 3.ed. São Paulo: LTr, 2012. p. 38-39.
} 
características profissionais. Neste contexto, algumas profissões podem ser elencadas: músicos auxiliares de culto, ourives, carpinteiros, tintureiros, sapateiros, curtidores, forjadores de cobre e oleiros. ${ }^{3}$

As referidas instituições constituíram verdadeira força devido ao número, organização, atribuições e privilégios atingidos. A princípio, faziam parte somente trabalhadores livres, tempos depois, puderam ser incorporados os libertos e alguns escravos. Quanto à existência, estava condicionada à autorização (prescindível a renovação do ato), a qual poderia ser revogada a qualquer tempo. Referente à documentação, deveriam possuir estatutos discutidos pelos membros e aceitos pela autoridade competente. ${ }^{4}$

Apesar dos colégios guardarem ligeiras semelhanças com os sindicatos, como a existência de estatutos; foram criados mediante determinação de autoridades, enquanto a entidade sindical moderna é corolário ao individualismo liberal, fazendo com que a classe obreira, em decorrência da falta de apoio estatal, reunisse seus membros em prol da defesa de direitos e exigências. $^{5}$

No século VII, na Alemanha e Inglaterra, foram constituídas as guildas, instituições que guardam semelhança e antecedência aos colégios romanos. Eram verdadeiras famílias artificiais, desenvolvidas sob o juramento de ajuda e socorro aos membros em acertadas situações, que se dividiam em três categorias: a) religiosa e social (formada por associações de defesa mútua ou de cristãos e não possuíam caráter profissional); b) artesãos; c) comerciantes (especialmente, para assegurar aos membros proteção e bens). As guildas inglesas ou alemãs tinham seus estatutos e se organizavam de forma democrática, uma vez que todos os membros participavam das assembléias e podiam votar nas eleições. ${ }^{6}$

${ }^{3}$ CABANELLAS, Guillermo. Compendio de derecho laboral. Buenos Aires: Bibliográfica Omeba, 1968. p. 66-67.

${ }^{4}$ Ibid., p. 66-67.

${ }^{5}$ VIANNA, José de Segadas. Organização sindical. In: SÜSSEKIND, Arnaldo; MARANHÃO, Délio; VIANNA, Segadas; TEIXEIRA, Lima. Instituições de direito do trabalho. 22.ed. São Paulo: LTr, 2005. v.ll. p. 1099.

${ }^{6}$ CABANELLAS, Guillermo (1968), op. cit., p. 69 
A similitude das guildas com os colégios romanos, contudo, não permite confusão entre os institutos, pois aquelas encerram características mutualísticas e beneficentes, consideradas "verdadeiros grêmios". 7

Não se pode olvidar das corporações medievais, associações de mestres de idêntico ofício que viviam na mesma localidade, detinham o monopólio rigoroso da fabricação, venda e regulamentação dos produtos no mercado. Tal instituto apresenta semelhança com os sindicatos patronais da atualidade, também eram compostos pelos companheiros (compagnons) e pelos aprendizes, esses dois grupos são comparados aos operários da modernidade. A despeito de alguns traços característicos em relação às entidades sindicais, remetiam apenas ao interesse da classe patronal. ${ }^{8}$

Nesse período, em decorrência da submissão dos aprendizes e companheiros aos mestres, a economia apresentava-se cerrada aos dois primeiros. Diante de tais circunstâncias, os compagnons formaram grupos (compagnonnages) para oporem-se ao regime corporativo e terem aceitadas suas exigências. Esses acontecimentos marcaram as primeiras etapas da ação coletiva em face das organizações oficiais das profissões. ${ }^{9} \mathrm{O}$ século XVI é considerado o preambular declínio das corporações de ofício, marcado pelo aumento do poderio real, por meio da aprovação dos estatutos, bem como da facilidade de entrada e retirada de membros.

Além disso, a expansão marítima ocasionou o enfraquecimento do monopólio produtivo, substituindo a pequena oficina pelas grandes indústrias, o que pôs fim aos traços de domesticidade e irmandade para dar lugar ao imponente número de operários. ${ }^{10}$

Consoante os ensinamentos de Orlando Gomes e Elson Gottschalk, tais conflitos ocorriam raramente e por isso não marcaram o verdadeiro

\footnotetext{
${ }^{7}$ SANTOS, Ronaldo Lima dos, op. cit., p. 31.

${ }^{8}$ GOMES, Orlando; GOTTSCHALK, Elson. Curso de direito do trabalho. 17.ed. atual. por José Augusto Rodrigues Pinto e Otávio Augusto Reis de Sousa. Rio de Janeiro: Forense, 2005. p. 537-538.

9 BATALHA, Wilson de Souza Campos. Sindicatos. Sindicalismo. São Paulo: LTr, 1992. p. 20

${ }^{10}$ CESARINO JR., A. F. Direito social brasileiro. 6.ed. ampl. e atual. com a colaboração de Marly A. Cardone. São Paulo: Saraiva, 1970. p. 111.
} 
"movimento de massa que assinalou a luta entre o capital e o trabalho no curso do século XIX". 11

O panorama alterou-se com as modificações tecnológicas trazidas pela primeira Revolução Industrial. Os indivíduos iniciaram um processo de agrupamento em torno das fábricas, contudo, sem o devido estabelecimento de condições adequadas para que esses homens pudessem obter o mínimo de humanidade. O sofrimento foi acentuado com as crises econômicas, levando à união e organização dessas pessoas, tendo manifestado junto a esses trabalhadores (operários) "a consciência de sua comunidade de interesses". ${ }^{12}$

A situação tornou-se mais difícil com o êxodo rural e o aumento massivo da mão de obra urbana, além disso, a aquisição de novo maquinário e preferência pelo trabalho feminino e infantil, fez com que o desemprego avançasse. Deste modo, "a técnica, criando uma nova psicologia e apoiada pelas novas forças econômicas, conduz a uma transformação da atmosfera doutrinária e política. É este clima que explica o nascimento do movimento operário moderno do sindicalismo". ${ }^{13}$

O sindicato como é conhecido na contemporaneidade, data da Revolução Industrial, por isso imprescindível a observação de alguns fatos ocorridos anterior a este momento, por volta do início do ano de 1720. Nesse período, mestres alfaiates rumaram em direção ao Parlamento Britânico, representados por uma associação composta de aproximadamente sete mil trabalhadores. Tal movimento almejava a conquista de melhor remuneração e a diminuição de uma hora da jornada diária de trabalho. Considera-se o fato mencionado como o início dos trade unions britânicos. ${ }^{14}$

Mauricio Godinho Delgado alerta para não se creditar a criação dos sindicatos a um marco tanto remoto, visto que o início do século XVIII ainda não albergava todas as condições adequadas, quais sejam: econômicas, sociais, políticas e ideológicas, fomentadoras da ação coletiva. Entretanto, segundo o autor, mesmo havendo divergências acerca do ponto inicial das entidades

\footnotetext{
${ }^{11}$ GOMES, Orlando; GOTTSCHALK, Elson, op. cit., p. 538.

12 lbid.

${ }^{13}$ Ibid., p.539.

${ }^{14}$ DELGADO, Mauricio Godinho. Curso de direito do trabalho. 12.ed. São Paulo: LTr, 2013. p. 1352
} 
sindicais, há uma certeza quanto ao local: na Inglaterra, propulsora da Revolução Industrial e de ideais capitalistas. ${ }^{15}$

Para tanto, é salutar observar o entendimento:

\begin{abstract}
Neste sentido, podemos afirmar que o nascimento do sindicalismo é a culminação e um longo processo histórico, cheio de antecedentes numerosos e importantes, que tinha por desaguadouro o ideal comum de valorização do homem como pessoa e de reconhecimento dos direitos essenciais à defesa de seus interesses e à expansão de sua personalidade. $^{16}$
\end{abstract}

Ante tais circunstâncias, faz-se imprescindível a apresentação de uma síntese dos antecedentes à criação dos sindicatos, analisando o período no qual se desenvolveu o sindicalismo, isto é, sua evolução até a entidade sindical contemporânea, inclusive pelos acontecimentos no território brasileiro.

\title{
2.1.1 Evolução sindical brasileira
}

A primeira Revolução Industrial ocorreu entre o final do século XVIII e início do século XIX no Reino Unido, especialmente na Inglaterra com a implantação da máquina a vapor e a rápida difusão pelo país. Consequentemente, o início dos movimentos sindicais também marcou tal período e região, por isso o território inglês pode ser compreendido, popularmente, como o berço do sindicalismo mundial.

Por outro lado, na época citada e em solo brasileiro, não houve o aparecimento vertiginoso de indústrias. Deve-se lembrar de que, até o fim do século XIX, perdurou o regime escravocrata, tendo a sua extinção sucedida vagarosamente com a edição de determinadas legislações, tais como: Lei Bill Aberdeen (Lei inglesa de 1845); Lei Eusébio de Queirós (1850); Lei do Ventre Livre (1871); e por fim, a Lei Áurea (13 de maio de 1888). Além disso, a economia era baseada quase que exclusivamente no sistema agrário.

\footnotetext{
${ }^{15}$ DELGADO, Mauricio Godinho, op. cit., p. 1354-1355.

${ }^{16}$ RUSSOMANO, Mozart Victor. Princípios gerais de direito sindical. 2.ed. ampl. e atual. Rio de Janeiro: Forense, 1995. p. 16-17.
} 
José Carlos Arouca informa que, no Brasil do século XIX, havia aproximadamente 648 mil estabelecimentos agrícolas e apenas 13.000 industriais. Primeiro, os senhores de engenho, em seguida, os fazendeiros de café, cuja mão de obra utilizada resumia-se aos ex-escravos. Essa parcela de operários (cerca de $60 \mathrm{mil}$ ) era insignificante perante a totalidade da população (14 milhões), por isso, "a classe trabalhadora não tinha nenhuma importância ou significado". Diante do aludido cenário, foi imperceptível de imediato a repercussão no solo brasileiro dos movimentos socialistas ocorridos na Europa. ${ }^{17}$

Nota-se que o processo industrial brasileiro é considerado tardio, uma vez que a efetiva Revolução Industrial tupiniquim ocorreu somente nas décadas iniciais do século XX, especialmente após a segunda Guerra Mundial. Em decorrência disso, o surgimento de notícias a respeito dos sindicatos e da legislação pertinente, também ocorreu de forma retardatária.

Os primeiros sinais do sindicalismo brasileiro, após a extinção das corporações de ofício, remetem às instituições assistenciais, cujo foco era a melhoria salarial e a redução da jornada de trabalho, tais como: a Liga Operária de Socorros Mútuos (1872), Liga de Resistência dos Trabalhadores em Madeira (1901), Liga dos Operários em Couro (1901) e Liga de Resistência das Costureiras (1906). ${ }^{18}$

O primeiro instrumento constitucional a tratar do direito de associação profissional foi a Constituição Imperial de 1824, em especial no $\S 25$ do artigo 25 , segundo o qual estavam abolidas as corporações de ofício. Já a Constituição de 1891, baseada no modelo norte americano, não fez qualquer referência ao assunto, apenas o Supremo Tribunal Federal quando julgou um habeas corpus em 22.11.1920 e interpretou o § 8 do artigo 72 ("a todos é lícito associarem-se e reunirem-se livremente e sem armas; não podendo intervir a polícia senão para manter a ordem pública") e estendeu a liberdade de associação também à garantia de sindicalização e à greve. ${ }^{19}$

\footnotetext{
${ }^{17}$ AROUCA, José Carlos. Curso básico de direito sindical. São Paulo: LTr, 2006. p. 79.

${ }^{18}$ NASCIMENTO, Amauri Mascaro. Origens históricas e natureza jurídica dos sindicatos. IN FRANCO FILHO, Georgenor de Sousa. (Coord.) Curso de direito coletivo do trabalho. Estudos em homenagem ao ministro Orlando Teixeira da Costa. São Paulo: LTr, 1998. p. 40.

${ }^{19}$ VIANNA, José de Segadas (2005), op. cit., p. 1124.
} 
O direito sindical brasileiro percorreu três fases distintas: 0 anarcossindicalismo, o intervencionismo e o sindicalismo autônomo. Em linhas gerais, a primeira fase corresponde aos princípios anarquistas convergentes ao movimento sindical, sob influência do fluxo imigratório ocorrido entre 1890 a 1920, com destaque para a aprovação do Decreto n. 979/1903 (sindicatos rurais) e Decreto n. $1.637 / 1907$ (sindicatos urbanos). ${ }^{20}$

Para Octavio Bueno Magano, o Decreto n. 979 de 6 de janeiro de 1903 é a primeira lei sindical brasileira, cuja principal função foi a de conceder à entidade sindical o papel de intermediadora do crédito em prol dos seus sócios, bem como a venda dos produtos explorados em espécie ou que tenham sido transformados. ${ }^{21}$

Segundo o referido decreto, de apenas doze artigos, facultavam-se aos profissionais da agricultura e indústrias rurais a formação de sindicatos para o estudo, custeio e a defesa dos seus interesses (art. $1^{\circ}$ ). O único requisito para a constituição legal da entidade era o depósito no cartório de registro de hipotecas de exemplares dos seguintes documentos: estatutos, ata, instalação e da lista de sócios, cujas cópias deveriam ser enviadas pelo escrivão à Associação Comercial do Estado onde fossem organizados os sindicatos (art. $2^{\circ}$ ). O Decreto n. 979 esteve vigente até 1938, quando foi revogado pelo Decreto n. 581 .

Em seguida, foi sancionado o Decreto Legislativo n. 1.637/1907 resultante do projeto apresentado pelo deputado Joaquim Ignacio Tosta, cuja solicitação procedeu de corporações, particularmente da Federação Operária Cristã de Pernambuco. ${ }^{22}$

O dispositivo normativo em comento possibilitou a organização de sindicatos de trabalhadores, até mesmo aqueles pertencentes à categoria de profissionais liberais, o que repercutiu para o surgimento de inúmeras entidades sindicais com inexpressivo poder de imposição. ${ }^{23}$ No citado Decreto, já era possível

\footnotetext{
${ }^{20}$ NASCIMENTO, Amauri Mascaro. Curso de direito do trabalho. p. 1200-1201.

${ }^{21}$ MAGANO, Octávio Bueno. Organização sindical brasileira. São Paulo: Ed. Revista dos Tribunais, 1981. p. 93.

${ }^{22}$ AROUCA, José Carlos (2006), op. cit., p. 81.

${ }^{23}$ RUSSOMANO, Mozart Victor, op. cit., p. 31.

Para tanto, cumpre observar o posicionamento de JOAQUIM PIMENTA acerca da repercussão de se organizar um sindicato e como o movimento sindical era combatido pelos empresários, assim: "Organizar um sindicato, por mais específico que fossem os intuitos de seus promotores; incutir no ânimo dos companheiros uma noção, menos elementar, de
} 
vislumbrar a liberdade sindical em âmbito individual, a pessoa era livre para não participar do movimento sindical, bem como para se desvincular, conforme dispunha 0 art. $5^{\circ}$.

Em 1922, fundou-se o Partido Comunista do Brasil, o qual se concentrou na vida sindical e, em 1929, graças a sua iniciativa, surge a Confederação Geral do Trabalho do Brasil (CGTB). ${ }^{24}$

A segunda fase do sindicalismo brasileiro, denominada de intervencionismo, iniciou-se a partir da década de 1930, em plena Era Vargas e com a criação do Ministério do Trabalho, Indústria e Comércio. Tal período baseou-se nos ideais corporativistas, que podem ser percebidos por meio das principais ações estatais, como o agrupamento de profissões idênticas, similares e conexas pela comissão de enquadramento sindical do Ministério do Trabalho; a criação de sindicatos atrelada à autorização do Estado; e a permissão para criação de Federações e Confederações. ${ }^{25}$

Em 1931, entrou em vigência o Decreto n. 19.770, para regular a sindicalização operária e patronal. A aquisição de personalidade jurídica da entidade sindical estava submetida à aprovação dos seus estatutos pelo Ministério do Trabalho, Indústria e Comércio (art. $2^{\circ}$ ), o órgão também era responsável pela ratificação dos acordos e convenções coletivas de trabalho (art. 10). Além disso, o art. 15 previa a intervenção de delegados junto às mencionadas instituições, seja para assistir as assembleias ou examinar a situação financeira. Evidentemente, tais procedimentos ferem a liberdade sindical e colocam o Estado como interventor no funcionamento dos sindicatos.

\footnotetext{
direitos que se tornaram vulgares na legislação de outros povos; discutir uma tabela de salários ou pleitear a redução dos honorários exaustivos, a que nem as crianças escapavam, era bastante para ser despedido, boicotado, e se a dispensa do empregado provocava protestos ou reação pela greve, a interferência do Estado imediatamente se fazia valer, detendo os mais ousados, dispensando ajustamentos à pata de cavalo, forçando os mais tímidos a voltarem ao trabalho." "Grandes empresas, privadas ou que exploravam serviços públicos, excediam-se na sua sistemática hostilidade a todo movimento associativo. Poucos eram os sindicatos que poderiam manter-se, desde que se organizassem sem a sua aquiescência, e, ainda, por elas controlados. Os que se constituíam em divergência, acabavam por dissolver-se pelo afastamento inevitável dos sócios mais prestigiosos, demitidos ou removidos para onde não mais pudessem exercer qualquer influência sobre a classe." IN: PIMENTA, Joaquim. Sociologia econômica e jurídica do trabalho. 5.ed. Rio de Janeiro: Freitas Bastos, 1957. p. 190.

${ }^{24}$ AROUCA, José Carlos (2006), op. cit., p. 80.

${ }^{25}$ NASCIMENTO, Amauri Mascaro (2007), op. cit., p. 1201-1202.
} 
Por isso, o Decreto n. 19.770 foi cotejado a um instrumento legislativo do movimento fascista italiano ou moldado aos costumes comunistas. Joaquim Pimenta discordou de tais comparações, cujas explicações são fundamentadas no momento vivido, ou seja, a situação na qual se encontrava a classe trabalhadora brasileira. O Estado deveria reconhecer o sindicato não apenas como uma simples sociedade civil, mas uma entidade capaz de estabelecer o equilíbrio da ordem jurídica na economia nacional. ${ }^{26}$

A promulgação do Decreto n. 19.770 ocorreu em 19 de março, transcorridos apenas três meses, haviam sido expedidas aproximadamente quatrocentas cartas a sindicatos de trabalhadores e mais de setenta para organizações de empregadores. ${ }^{27}$

Em 1934, aprovou-se o Decreto n. 24.694, que dispôs sobre os sindicatos profissionais, entretanto, não apresentou inovações quanto à autonomia, bem como ao público alvo. Quanto à base territorial, as entidades representativas dos trabalhadores eram restritas ao espaço local, dando a impressão de facilitar a integração entre os membros ou o receio do governo na constituição de organizações poderosas. Cumpre enfatizar a função assistencial atribuída pelo decreto, isto é, o oferecimento de determinados serviços aos associados para que assim o Estado pudesse controlar as possíveis reivindicações. ${ }^{28}$

Nesse contexto, promulgou-se a Carta Constituinte de 1934, com previsão expressa às entidades sindicais no art. 120, segundo o qual "os sindicatos e as associações profissionais serão reconhecidos de conformidade com a lei" e "a lei assegurará a pluralidade sindical e a completa autonomia dos sindicatos". Entretanto, a pluralidade restou prejudicada em decorrência do Decreto Legislativo n. 24.694, uma vez que exigia a quantidade de um terço do grupo de trabalhadores para a formação da organização sindical. ${ }^{29}$

A Constituição outorgada de 1937 retirou o direito de greve do trabalhador, mas previu o direito de associação profissional, segundo o qual:

\footnotetext{
${ }^{26}$ PIMENTA, Joaquim, op. cit., p. 192.

27 RUSSOMANO, Mozart Victor, op. cit., p. 32.

${ }^{28}$ MAGANO, Octávio Bueno (1981), op. cit., p. 99-105.

${ }^{29}$ VIANNA, José de Segadas (2005), op. cit., p. 1124-1125.
} 


\begin{abstract}
Art. 138 - A associação profissional ou sindical é livre. Somente, porém, o sindicato regularmente reconhecido pelo Estado tem o direito de representação legal dos que participarem da categoria de produção para que foi constituído, e de defender-lhes os direitos perante o Estado e as outras associações profissionais, estipular contratos coletivos de trabalho obrigatórios para todos os seus associados, impor-lhes contribuições e exercer em relação a eles funções delegadas de Poder Público.
\end{abstract}

A Constituição de 1937, também chamada de ditatorial, revogou a Carta de 1934 e proclamou o princípio da unicidade, bem como a submissão ao Ministério do Trabalho, ou seja, relacionou os sindicatos novamente ao Estado, o que perdurou até a Constituição de 1988, seja por descaso dos constituintes ou do legislador ordinário. ${ }^{30}$

Em seguida, houve a edição do Decreto n. 1.402/1939, outro modelo corporativista de repressão, uma vez que também submetia o enquadramento sindical à ação do Ministério do Trabalho, bem como a cassação da carta de reconhecimento em caso de descumprimento da legislação. ${ }^{31}$ Não se pode olvidar do Decreto Lei n. 5.452, de 1ำ de maio de 1943, o qual instituiu a Consolidação das Leis do Trabalho.

O legislador constituinte de 1946 estabeleceu o direito de associação no art. 159, ao dispor que era "livre a associação profissional ou sindical, sendo reguladas por lei a forma de sua constituição, a sua representação legal nas convenções coletivas de trabalho e o exercício de funções delegadas pelo Poder Público". Nota-se que o texto constitucional somente tratou do assunto de forma genérica, delegando à legislação infraconstitucional a incumbência de dispor efetivamente sobre a formação e os critérios de representatividade.

Quanto à terceira fase do movimento sindical, chamada de sindicalismo autônomo, é marcada pelo rompimento com o modelo estatal intervencionista, ou seja, o Estado deixou de repercutir no cotidiano dos sindicatos. Trata-se de um período de abertura política, o que possibilitou a criação de centrais sindicais sem o esteio legal, por exemplo. ${ }^{32}$

Além disso, o Ministério do Trabalho e Emprego deixou de seguir algumas orientações da CLT no que diz respeito à fundação dos sindicatos.

\footnotetext{
${ }^{30}$ RUSSOMANO, Mozart Victor, op. cit., p. 33.

${ }^{31}$ NASCIMENTO, Amauri Mascaro (2007), op. cit., p. 1202.

${ }^{32}$ Ibid., p. 1203-1204.
} 
Tornou-se livre o processo de criação de uma entidade sindical, já não havia a necessidade de se constituir previamente uma simples associação e, após um período de estágio, solicitar a carta sindical conforme os requisitos legais. Desse modo, o funcionamento das organizações sindicais passou a fazer parte da sua administração interna, sem fiscalização do poder público. ${ }^{33}$

Por outro lado, a estruturação prevista na Constituição Federal de 1988 impulsionou a criação de um sistema incoerente, uma vez que instituiu a unicidade sindical sob o amparo da lei, porém, favoreceu a pluralidade sindical de fato, especialmente quanto às centrais sindicais e à fragmentação de categorias. Tal conjuntura provocou o aumento vertiginoso do número de sindicatos e a consequente fragilização do movimento sindical. ${ }^{34}$

\subsection{Estrutura sindical brasileira na Constituição Federal de 1988}

\subsubsection{Entidades sindicais}

\subsubsection{Conceito}

Basicamente, sindicato pode ser definido como a entidade de direito privado constituída por um grupo de trabalhadores ou empregadores (de cunho profissional ou econômico, respectivamente), para a defesa dos interesses do aludido conjunto de pessoas, observado o registro no órgão competente, o qual the garante a personalidade sindical. Quanto à origem etimológica, a palavra sindicato deriva do termo em latim syndicus (síndico) e do grego sundikós (advogado).

Para Amauri Mascaro Nascimento, sindicato "é uma organização social constituída para, segundo um princípio de autonomia privada coletiva, defender os interesses trabalhistas e econômicos nas relações coletivas entre os grupos sociais". 35

\footnotetext{
${ }^{33}$ NASCIMENTO, Amauri Mascaro (2007), op. cit., p. 1205.

${ }^{34}$ Ibid., p. 1205-1206.

${ }^{35}$ Ibid., p. 1254.
} 
Segundo Wilson de Souza Campos Batalha, entidade sindical consiste em uma pessoa jurídica de direito privado, a qual se investe legitimidade para substituir processualmente seus representados em prol dos interesses da coletividade. Para tanto, essa representação caracteriza-se por meio da identidade, ou similaridade, ou conexidade, referente ao trabalho ou face à empresa, coexistindo o binômio: sindicato de categoria profissional e sindicato de categoria econômica. ${ }^{36}$

Para Roberto Barreto Prado, sindicato é "a associação que tem por objeto a representação e defesa dos interesses gerais da correspondente categoria profissional ou econômica e, supletivamente, dos interesses individuais dos seus membros". 37

José de Segadas Vianna atenta para a diversificada conceituação de sindicato em decorrência das complexas atribuições no cotidiano de um povo. Segundo o autor, a doutrina clássica trata a entidade sindical como uma coalizão duradoura para a luta de classes, enquanto uma parcela compreende tratar-se de um órgão destinado à solução do problema social. Por outro lado, na legislação, encontra-se desde a definição clássica à moderna. Nesse sentido, a Lei francesa de 1884 (reformada em 1920 e incorporada ao Código do Trabalho) estabelece que os sindicatos são formados "por pessoas que exercem a mesma profissão e têm exclusivamente por objeto o estudo e a defesa dos interesses econômicos, industriais, comerciais, e agrícolas". ${ }^{38}$

Wilson de Souza Campos Batalha recorre à "clássica definição" de Paul Durant, a qual alude somente às entidades representativas de categorias profissionais:

O sindicato é um agrupamento no qual várias pessoas, exercentes de uma atividade profissional, convencionam pôr em comum, de maneira duradoura e mediante organização interna, suas atividades uma parte de seus recursos, em vista de assegurar a defesa e a representação de sua profissão e de melhorar suas condições de existência. ${ }^{39}$

\footnotetext{
${ }^{36}$ BATALHA, Wilson de Souza Campos, op. cit., p. 56-57.

${ }^{37}$ PRADO, Roberto Barreto. Curso de direito sindical. São Paulo: LTr, 1991. p. 20.

${ }^{38}$ VIANNA, José de Segadas (2005), op. cit., p. 1120.

${ }^{39}$ DURANT, Paul apud Wilson de Souza Campos, op. cit., p. 56.
} 
Nessa linha de pensamento, Guillermo Cabanellas explica que a palavra sindicato sempre inclui conceitos coletivos e profissionais, assim:

\begin{abstract}
No Direito do Trabalho, por sindicato se entende toda organização ou associação profissional composta ou integrada por pessoas que, exercendo o mesmo ofício ou profissão, similares ou conexas, unemse para o estudo ou proteção dos interesses que lhes são comuns. Qualquer entidade profissional que tenha por objeto a defesa dos interesses comuns da atividade laboral de seus membros, pode chamar-se sindicato. ${ }^{40}$
\end{abstract}

Manuel Alonso Olea a partir da definição ${ }^{41}$ de Sidney e Beatriz Webb (1894) ensina que o sindicato pode ser uma associação permanente de trabalhadores sem fins lucrativos, visando à progressão econômica e social dos membros, objetivando, por meio da contratação coletiva, a manutenção e melhoria das condições de trabalho. ${ }^{42}$

Giuseppe D’Eufemia faz a diferenciação entre associação operária e patronal. Desta forma, a primeira, surge como um fenômeno jurídico no momento da sua organização, os trabalhadores associam-se na base de idêntica atividade laboral ou no chamado sindicato de indústria, ou seja, a associação consiste no agrupamento dos indivíduos que participam do mesmo ciclo de produção. Isso ocorre objetivando a tutela de interesses profissionais comuns dos associados, especialmente para contrastar perante o monopólio da categoria formada pelos empregadores, em prol de condições de trabalho e da substituição dos trabalhadores isolados. ${ }^{43}$

Quanto à associação patronal, são criadas com o intuito de resistência às reivindicações das associações de trabalhadores, bem como para a defesa de interesses econômicos e são organizadas na base por diversos critérios, como o setor de produção ou pela dimensão da empresa. ${ }^{44}$

${ }^{40}$ CABANELLAS, Guillermo (1968), op. cit., p. 152. (tradução livre)

${ }^{41}$ Para Sidney Webb e Beatriz Webb, "um sindicato, como nós entendemos o termo, é uma contínua associação de trabalhadores assalariados para a finalidade de manter ou melhorar as condições de suas vidas profissionais". (Tradução livre). In: WEBB, Sidney; WEBB, Beatriz. The history of trade unionism. New York: Longmans, Green, 1950. p. 01.

${ }^{42}$ ALONSO OLEA, Manuel Alonso. Derecho del trabajo. 6.ed. Madrid: Universidad de Madrid - Facultad de Derecho, 1980. p. 386.

${ }^{43}$ D’EUFEMIA, Giuseppe. Diritto sindacale. Napoli: Morano Editore, 1967. p. 14-15.

${ }^{44}$ Ibid., p. 15. 
No sistema legislativo brasileiro, não é possível visualizar o conceito de sindicato nem mesmo na Consolidação das Leis do Trabalho (CLT). No diploma celetista, encontra-se a referência à possibilidade de associação para fins de estudo, defesa e coordenação dos interesses profissionais e econômicos (art.511), as prerrogativas (art. 513) e deveres sindicais (art. 514). Para tanto, torna-se salutar a observação do artigo celetista:

Art. 511. É lícita a associação para fins de estudo, defesa e coordenação dos seus interesses econômicos ou profissionais de todos os que, como empregadores, empregados, agentes ou trabalhadores autônomos ou profissionais liberais exerçam, respectivamente, a mesma atividade ou profissão ou atividades ou profissões similares ou conexas.

Por outro lado, é possível localizar na legislação estrangeira alusão a conceitos básicos do sindicalismo. Em Portugal, por exemplo, no Decreto-Lei n. 215-B de 30 de abril de 1975, o sindicato é considerado uma associação de trabalhadores que visa à defesa e a promoção dos interesses do grupo, definição disposta no art. $2^{\circ}$. Quanto à aquisição da personalidade sindical, esta ocorre por meio do registro dos estatutos no Ministério do Trabalho.

Observa-se, na maioria dos conceitos trazidos pela doutrina, um direcionamento ao poder de representação ou defesa de interesses de terceiros, associados ou não. Tal competência mostra-se extremamente salutar na aquisição de força dos atores sociais, especialmente, aqueles pertencentes à classe de trabalhadores, cujo poderio individual é imperceptível ou insuficiente perante a autoridade do empregador, visto que o embate direto poderia suscitar receios ou represálias.

\subsubsection{Natureza jurídica}

A indicação da natureza jurídica do sindicato permite individualizá-lo e compreender melhor suas funções e características, evitando a confusão de institutos, especialmente no que diz respeito ao grupo representado. 
Octávio Bueno Magano ressalta que "o sindicato possui realidade complexa: participa da natureza da associação, mas ostenta, ao mesmo tempo, inúmeros traços institucionais. Deve ser por isso caracterizado como associação institucionalizada". 45

Consoante Mauricio Godinho Delgado, a entidade sindical consiste em uma associação coletiva, possuindo natureza privada, a fim de defender os interesses coletivos profissionais e materiais de trabalhadores, estejam subordinados ou autônomos, e de empregadores. ${ }^{46}$

Três teorias devem ser observadas acerca da natureza jurídica dos sindicatos ante a delimitação entre o direito público e 0 direito privado. Primeiramente, a teoria do fim, a qual o interesse público determina a natureza jurídica do ente, visando a atender as peculiaridades do Estado. Evidentemente, a citada teoria não prevaleceu, pois em determinadas circunstâncias, a pessoa jurídica de direito privado poderá exercer, por delegação, atividades correlatas ao ente estatal, bem como a entidade de direito público efetuar tarefas do ramo privado. No que concerne à organização sindical, suas atividades não se destinam a concretização de um fim público que demande a delegação. ${ }^{47}$

Em seguida, a teoria da funcionalidade, refere-se ao tratamento da subordinação da atividade da pessoa jurídica ao controle, à vigilância e à tutela do Estado. Nesse caso, considera-se de direito público a pessoa jurídica cuja totalidade de operações dependa do aval estatal. A mencionada teoria foi refutada, uma vez que está dentre as funções estatais a tutela dos interesses coletivos de profissões e indivíduos. ${ }^{48}$

Já a terceira teoria, denominada integral ou eclética, se dá quando o Estado proclama o caráter público da pessoa jurídica ou a cria com esta natureza. Todavia, a simples interferência não demonstra a natureza pública, como acontece com as sociedades de economia mista, em que há a participação do Estado, o que não afasta o entendimento de pessoa jurídica de direito privado. ${ }^{49}$

\footnotetext{
${ }^{45}$ MAGANO, Octávio Bueno (1981), op. cit., p. 16

${ }^{46}$ DELGADO, Mauricio Godinho, op. cit., p. 1350.

${ }^{47}$ GOMES, Orlando; GOTTSCHALK, Elson, op. cit., p. 561.

48 Ibid., p. 561-562.

${ }^{49}$ Ibid., p. 561.
} 
Não há um divisor geométrico e rígido entre o interesse público e o interesse privado, há uma verdadeira intersecção, ou seja, em algum momento eles se conectam. Quanto ao sindicato ser de direito público ou privado, é necessário observar a lei local, além disso, o período histórico influenciará severamente nessa classificação. Nos sistemas ditatoriais, por exemplo, a legislação atribui à entidade sindical papel de colaboradora do Estado, subordinando-a ao poder político e sua consequente transformação em pessoa de direito público. Por outro lado, nas democracias é possível vislumbrar a pessoa de direito privado, que pode ser uma cooperadora estatal em assuntos de relevo, no entanto, não está suscetível ao domínio político. ${ }^{50}$

O denominado sindicato de direito público encontra respaldo nos ordenamentos estatais contrários à autonomia sindical, cuja atribuição pública é responsável pela ingerência direta do Estado em diversos momentos, tais como: na constituição, reconhecimento jurídico e no desenvolvimento da atividade sindical. Ante isso, há uma transformação dos caracteres naturais da entidade, por exemplo, na autonomia aludida, a qual se torna limitada e publicista, portanto, a natureza pública além de mitigar, desnatura a organização sindical. ${ }^{51}$

De acordo com a tendência moderna, especialmente em países como a Itália, Inglaterra e França, o sindicato é pessoa jurídica de direito privado e, em dadas situações, de interesse público. A atribuição de direito privado não significa exclusivamente a trajetória dos interesses privados, mas dos particulares, cujos envolvidos podem ser indivíduos ou grupo de pessoas, consequentemente, o direito público não remete apenas aos interesses coletivos, atingindo o âmbito dos interesses gerais da comunidade. ${ }^{52}$

A. F. Cesarino Jr. sustenta que os sindicatos não se enquadram como pessoas jurídicas de direito privado ou pessoas jurídicas de direito público, por isso considera que seria mais lógico adotar a classificação de pessoa jurídica de direito social. ${ }^{53}$

\footnotetext{
${ }^{50}$ RUSSOMANO, Mozart Victor, op. cit., p. 53-55.

${ }^{51}$ MAZZONI, Giuliano. Relações coletivas de trabalho. Trad. Antonio Lamarca. São Paulo: Ed. Revista dos Tribunais, 1972. p. 05.

${ }^{52}$ RUSSOMANO, Mozart Victor, op. cit., p. 56-57.

${ }^{53}$ CESARINO JR., A. F., op. cit., p. 137.
} 
Compartilha-se 0 entendimento de que 0 sindicato deva ser reconhecido como pessoa jurídica de direito privado, sem qualquer relação subordinada ao poder estatal, isto é, ausente o controle do modus operandi, bem como quaisquer requisitos que possam restringir ou condicionar sua formação, inclusive, quanto aos critérios de agregação de trabalhadores e empregadores, como o de categorias.

2.2.2 Sistema de representação sindical: sistema piramidal

A estrutura sindical brasileira está disposta na Constituição Federal de 1988 (arts. 8 a 11) e na Consolidação das Leis do Trabalho de 1943 (arts. 511 a 625) e apresenta características de um regime livre e corporativista simultaneamente, ou seja, aspectos e elementos de liberdade em contraponto a fundamentos intervencionistas, por isso denominada estrutura sindical híbrida. Esse conjunto é formado por graus de representação, precisamente por três divisões, o qual se denomina sistema piramidal.

$\mathrm{Na}$ base dessa pirâmide encontram-se os sindicatos, representantes dos interesses individuais e coletivos de empregados e empregadores, assim como da categoria profissional diferenciada. Comumente, há entidades sindicais que abarcam os níveis municipal, intermunicipal, estadual ou nacional respeitado o modelo de organização de unicidade sindical.

Em seguida, no grau intermediário de sustentação, estão localizadas as federações, que consistem no agrupamento mínimo de cinco sindicatos representantes da maioria absoluta de um grupo de atividades ou profissões idênticas, similares ou conexas. Geralmente, sua atuação é limitada ao âmbito estadual, podendo estender-se ao nível interestadual ou nacional (art. 534, CLT). Na cúspide ou cúpula da pirâmide, estão as confederações, cuja formação legal mínima é de três federações, normalmente de desempenho nacional (art. 535, CLT).

No tocante à legislação internacional, a Convenção n. 87 da OIT (art. 5ํ) preceitua o direito dos trabalhadores e empregadores constituírem as ditas 
organizações de nível elevado, porém, não há menção à quantidade mínima de instituições filiadas. Mas, o sistema brasileiro coloca-se em oposição acerca da referida normatização, tal como o impedimento da pluralidade de entidades superiores representantes da mesma categoria em determinado perímetro.

Com relação ao número de sindicatos para a composição inicial de uma federação, há que se ponderar a exigência mínima apregoada pelo legislador (art. 534, CLT), uma vez que após a Constituição Federal de 1988 ocorreu a fragmentação de inúmeras organizações sindicais, o que obstaculizou a reunião absoluta (mais de 50\%) de membros pertencentes da mesma classe de trabalhadores ou patronal em apenas cinco unidades. O mesmo problema incide na formação de uma federação pelo processo de cisão, pois nenhuma das duas associações poderá ficar com menos de cinco sindicatos. Propugna-se a liberdade para que os interessados decidam a formação da federação, seja pela criação inicial ou por processos de cisão e fusão. ${ }^{54}$

Homero Batista Mateus da Silva declara a eminência das federações e confederações na coordenação e defesa dos atores sociais, já que o desempenho dos inúmeros sindicatos de base, geralmente por meio de ações individualizadas, não alcança resultados capazes de incutir na trajetória de desenvolvimento do país ou influenciar o legislador à produção de normas jurídicas. Assim, "o grau superior da estrutura sindical corresponde, enfim, ao momento de transição entre o mero ativismo sindical do ponto de vista estritamente trabalhista e o papel político-social, que transcende os limites do direito do trabalho". ${ }^{5}$

O art. $611, \S 2^{\circ}$, CLT autoriza unicamente a atuação supletiva das associações superiores. Mas, a força do sistema confederativo deveria ser melhor aplicada também às negociações coletivas de cunho laboral, visto que resultariam em acordos unitários atentos às necessidades da comunidade trabalhista de forma homogênea, contudo, sem desqualificar a participação local dos sindicatos de base. Dessa forma, unifica-se o poder de diálogo superior ao atendimento das necessidades regionais. Notoriamente, essa fórmula adéqua-se exclusivamente às convenções coletivas, já que se tornaria árdua a pactuação de

\footnotetext{
${ }^{54}$ SILVA, Homero Batista Mateus da. Curso de direito do trabalho aplicado. Direito coletivo do trabalho. 2.ed. rev. e ampl. Rio de Janeiro: Elsevier, 2012. v. 7 p. 73.

${ }^{55}$ Ibid., p. 71.
} 
uma federação com cada uma das empresas representantes das categorias econômicas, por exemplo.

No direito espanhol, as entidades de grau superior são denominadas organizações sindicais complexas, consistem no agrupamento de unidades de nível inferior com especial intento de ampliar a capacidade negociadora e o âmbito de representação sindical. Formam-se a partir de critérios territoriais ou funcionais, bem como por outros fatores, como a filiação. Em decorrência desse processo de constituição, é possível vislumbrar a existência de federações por ramo ou setor, as uniões territoriais, as confederações centrais sindicais e as organizações internacionais. ${ }^{56}$

A referência às entidades de grau superior impõe, outrossim, repercussão às centrais sindicais, que são associações constituídas por organizações sindicais de representação dos trabalhadores. Apesar do seu reconhecimento legal, não estão na estrutura formal da Constituição Federal, por isso não são consideradas sindicatos e não podem exercitar certas atividades correlacionadas aos mencionados entes coletivos, por exemplo, firmar negociação coletiva.

Embora não possuam personalidade sindical e o consequente acesso às prerrogativas prescritas pelo art. 513 da CLT, de acordo com o art. $1^{\circ}$, II da Lei n. 11.648/2008, as centrais sindicais podem participar de negociações em fóruns, colegiados de órgãos públicos e demais espaços de diálogo social de composição tripartite, como o Conselho Curador do FGTS.

Na década de 1990, portanto, anterior à aprovação da Lei que regulamenta as centrais sindicais, já se apontava a importância dessas associações, consideradas de maior expressividade quando comparadas a certos sindicatos e até mesmo confederações, pois lograram êxito em assuntos envolvendo a temática trabalhista extensos aos interesses setoriais da categoria. Todavia, sua inclusão à estrutura sindical brasileira é dificultada pela unicidade, uma vez que a agregação de trabalhadores resulta de "múltiplas opções de filiação", em sentido oposto ao monismo que é concebido a partir das categorias econômicas e profissionais. Confere-se às centrais sindicais um papel

\footnotetext{
${ }^{56}$ VALVERDE, A. M.; GUTIÉRREZ, F. R. S.; MURCIA, J. G. Derecho del trabajo. 5.ed. Madrid: Tecnos, 1996. p. 255.
} 
transcendente à proteção de nível local ou nacional do trabalhador, estão correlacionadas à salvaguarda das regras internacionais. ${ }^{57}$

Apesar de defender interesses trabalhistas, as centrais sindicais não estão inseridas no contexto tradicional da estrutura sindical brasileira, mas são custeadas por parte da contribuição sindical. Essa participação tem precipitado diversas disparidades, já que sua natureza jurídica restringe-se a uma associação de direito privado sem personalidade sindical, no entanto, é financiada pelo numerário destinado às organizações sindicais consoante à regulamentação da Lei n. 11.648/2008. Em virtude disso, questiona-se a constitucionalidade do citado dispositivo legal, mediante a Ação Declaratória de Inconstitucionalidade (ADI) $\mathrm{n}$. 4.067 ajuizada pelo Partido Político Democratas - DEM em 09/04/2008. ${ }^{58}$

A ADI foi proposta em face dos artigos $3^{\circ}$ e $1^{\circ}$, II da Lei que reconhece formalmente as centrais sindicais, assim como do art. 589, II, b e art. 593, $\S 2^{\circ}$ da CLT, cuja redação foi designada pela legislação supracitada. Na petição inicial, argumentou-se que a contribuição sindical possui um fim específico, não podendo ser utilizada para o custeio de atividades que excedam a categoria profissional. Ademais, um tributo destina-se ao Estado, excepcionalmente às entidades não estatais contempladas no texto constitucional, mas não é o caso das centrais sindicais, cuja "atuação, a toda evidência, ultrapassa a noção de categorias profissionais ínsita à própria natureza sindical da contribuição”.

$\mathrm{Na}$ citada ação, indagou-se também a participação das centrais nos fóruns e órgãos públicos de formação tríplice, pois, nessa situação, as associações representam os trabalhadores sem a devida delegação da parte interessada, a qual é direcionada apenas às entidades sindicais.

A discussão em torno da (in) constitucionalidade da destinação da contribuição sindical às centrais sindicais não retrata a problemática enfrentada pelo sindicalismo brasileiro há décadas. É certo que uma negociação atrelada aos interesses profissionais no local de trabalho tende a ser vantajosa ao trabalhador, mas as melhorias das condições laborais não são restritas ao interior da empresa,

\footnotetext{
${ }^{57}$ MACIEL, José Alberto Couto. Papel das centrais sindicais. In: FRANCO FILHO, Georgenor de Sousa. (Coord.) Curso de direito coletivo do trabalho. Estudos em homenagem ao Ministro Orlando Teixeira da Costa. São Paulo: LTr, 1998. p. 125-133.

${ }^{58}$ Informações obtidas a partir do andamento processual previsto no sítio eletrônico do Supremo

Tribunal Federal.
} 
existem direitos carecedores de debates de maior relevância, como o desemprego em épocas de crise, o que não ocorre na base sindical adstrita aos interesses de um dado grupo profissional, além da inexpressividade de certas entidades no contexto regional e nacional.

Independente dos questionamentos acerca da manutenção da contribuição sindical no ordenamento brasileiro, impedir o repasse às centrais sob a justificativa de não ser uma organização sindical diverge de uma solução adequada, já que tal enquadramento ocorre devido à imposição da unicidade. Por isso, a tendência não é a vedação, mas a democratização do sistema, isto é, permitir a coexistência de instituições independente do plano de representação.

\subsubsection{Liberdade de criação}

Segundo o Código Civil brasileiro, o início legal de uma pessoa jurídica comum de direito privado ocorre com o registro dos seus atos constitutivos no respectivo Cartório ou Junta Comercial e, em dadas circunstâncias, carecem de autorização ou aprovação do Poder Executivo.

No tocante à formação dos sindicatos, José Martins Catharino sistematizou a aquisição da personalidade sindical em três fases, quais sejam: "a) da gestação, da ideia associativa ao ato criador consequente; b) nascimento, com o mesmo ato, constitutivo e estatutário, criador da 'associação profissional' sujeita ao registro; da maturidade, correspondente ao reconhecimento e à investidura sindicais." 59

Outrossim, o surgimento de uma entidade sindical, geralmente, ocorre a partir de uma das seguintes hipóteses: fundação originária, será o primeiro órgão representativo da categoria em determinada localidade; fundação por transformação de associação em sindicato, advém da mudança do status de simples associação para sindicato, assim como a aquisição de prerrogativas sindicais; fundação por desmembramento de categoria, a entidade representa

\footnotetext{
${ }^{59}$ CATHARINO, José Martins. Tratado elementar de direito sindical: doutrina, legislação. São Paulo: LTr, 1977. p. 170.
} 
atividades e há a separação de uma delas para a criação de um sindicato específico; fundação por divisão de base territorial, um sindicato de base ampla (nível nacional, estadual ou intermunicipal) fragmenta-se e dá origem a outro de localização geográfica específica e menor; fundação por fusão de sindicatos, dois ou mais sindicatos passam por um processo de transformação (união) e surge uma novo ente. ${ }^{60}$

As organizações sindicais prescindem de autorização para sua fundação, assim, proíbe-se a ingerência estatal na sua criação e funcionamento. Mas, a existência formal depende também da obtenção de personalidade sindical, consequente do depósito dos estatutos da entidade junto ao órgão competente, o Ministério do Trabalho e Emprego, conforme leitura extensiva do art. $8^{\circ}$, I da Constituição Federal de 1988. Trata-se apenas de um ato vinculado, ou seja, atendido o critério de territorialidade o registro deverá ser concedido.

Tal procedimento burocrático recebeu inúmeras críticas, apontado durante largo período como uma típica interferência do Estado. No decorrer da História do Direito Coletivo do Trabalho, diversas hipóteses foram aventadas com o intuito de explicar a formação da entidade sindical.

Primeiramente, surgiria a partir do reconhecimento oficial e aprovação da sua constituição pelo Poder Público, enquanto em outro entendimento apenas com a sua criação, sem a necessidade da ratificação dos entes públicos. Há quem justificasse o nascimento da pessoa jurídica por um acordo de vontades com um objetivo concreto. Por fim, há a corrente segundo a qual a pessoa jurídica possui vida desde o momento do pacto de vontades para um fim concreto, porém, vem o ente estatal e a legaliza com sua autorização. ${ }^{61}$

De acordo com José de Segadas Vianna, "o Estado não tem poder de criar sindicatos e apenas estabelece condições para que eles sejam registrados para o exercício de direitos que as leis lhes conferem. Os sindicatos nascem da vontade de um grupo profissional homogêneo". 62

\footnotetext{
${ }^{60}$ NASCIMENTO, Amauri Mascaro. Compêndio de direito sindical. 7.ed. São Paulo: LTr, 2012. p. 264.

${ }^{61}$ CABANELLAS, Guilhermo. Derecho sindical y corporativo. Buenos Aires: Atalaya, 1946. p. 233.

${ }^{62}$ VIANNA, Segadas (2005), op. cit., p. 1123.
} 
Precedente à Carta constitucional atual, a conjuntura era evidentemente intervencionista, a criação de um ente demandava reconhecimento estatal. Portanto, um poder discricionário do órgão concedente, ou seja, poderia conferir ou não a formalização da entidade.

A Constituição de 1934 sujeitava o reconhecimento dos sindicatos à legislação infraconstitucional. A norma constitucional de 1937 assegurava o exercício representativo apenas às entidades devidamente legitimadas pelo Estado; enquanto os diplomas de 1946 e 1967 incumbiram à lei de regular a constituição, representação e as funções delegadas pelo Poder Público.

O texto constitucional em vigor ao sistematizar o registro em órgão competente, não definiu qual seria a instituição, e tal lapso legislativo impulsionou diversas discussões interpretativas. Consequentemente, de um lado, defensores do Ministério do Trabalho como órgão ratificador; em oposição, críticos que consideravam o procedimento uma forma de ingerência estatal e, portanto, caberia aos cartórios de registro civil realizar a devida abertura de assento. A celeuma sofreu intervenção do Superior Tribunal de Justiça no mandado de segurança n. 29 (DF) ${ }^{63}$, o qual atribuiu a competência residual ao Ministério do Trabalho até que sobreviesse lei ordinária disciplinando o assunto. ${ }^{64}$

O disciplinamento do órgão responsável pelo registro sindical não ficou adstrito ao STJ, também dispuseram sobre o assunto o Tribunal Superior do Trabalho e o Supremo Tribunal Federal, com a Orientação Jurisprudencial n. 15 da Seção de Dissídios Coletivos e a súmula n. 677 , respectivamente. ${ }^{65}$

${ }^{63}$ EMENTA: MANDADO DE SEGURANÇA - ORGANIZAÇÃO SINDICAL - REGISTRO DE ENTIDADE SINDICAL - ATRIBUIÇÃO - CONSTITUIÇÃO FEDERAL, ART. 8으, ITENS I E II. - A Constituição Federal erigiu como postulado a livre associação profissional e sindical, estabelecendo que a lei não pode exigir autorização do Estado para a fundação de sindicato, ressalvado o registro no órgão competente, vedadas ao Poder Público a interferência e a intervenção na organização sindical. Persistência, no campo da legislação de regência, nas regras legais anteriores que não discrepam da nova realidade constitucional, antes dão-lhe embasamento e operatividade. Atribuição residual, enquanto lei ordinária não vier dispor de outra forma. Atuação restrita, no caso, à verificação da observância ou não da ressalva constitucional que veda a existência de organização sindical da mesma categoria profissional em idêntica base territorial. - Segurança em parte concedida. STJ. MS n. 29 - DF - (Registro n. 89.72838) DJ:14.11.1989

${ }^{64}$ AROUCA, José Carlos. Repensando o sindicato. São Paulo: LTr, 1988. p. 83-84.

65 (TST - OJ - SDC - 15) Sindicato. Legitimidade "ad processum". Imprescindibilidade do registro no Ministério do Trabalho A comprovação da legitimidade "ad processum" da entidade sindical se faz por seu registro no órgão competente do Ministério do Trabalho, mesmo após a promulgação da Constituição Federal de 1988. (inserida em 27.03.1998) 
O objetivo do registro sindical está relacionado ao cadastro do sindicato mais representativo e que esteja apto a cobrar a contribuição. Ademais, os estatutos devem ser averbados no cartório de registro de títulos e documentos para adquirir personalidade jurídica e dar publicidade ao ato, enquanto o depósito no mencionado órgão do Poder Executivo possui fins de verificação da base territorial mínima e lhe garantir a personalidade sindical. ${ }^{66}$

Não obstante, portarias e instruções do Ministério do Trabalho e Emprego, especialmente a Portaria n. 186/2008, receberam avaliação negativa por exorbitarem seu campo de atuação. Segundo Cássio de Mesquita Barros Junior, tais dispositivos não estariam apenas regulamentando e, sim, exercendo o papel de legislação, por exemplo, com a concessão ao aludido órgão o direito de decidir sobre as impugnações dos pedidos de registro sindical, quando deveria exclusivamente receber e publicá-los, assim como as manifestações. ${ }^{67}$

O procedimento de depósito dos estatutos, por vezes, torna o exercício da vida sindical moroso, incidindo prejuízos à entidade representante e à classe representada, pois, enquanto pendente a formalização do registro, não há a possibilidade de usufruir das principais prerrogativas, como a função de firmar acordos e convenções coletivas de trabalho. ${ }^{68}$

Não se pode olvidar que o ordenamento constitucional brasileiro prevê a liberdade de associação profissional e sindical, por isso permite-se a coexistência de sindicatos e associações profissionais, as quais independem de observância territorial e devem ser reconhecidas exclusivamente no âmbito civil. Seus dirigentes não desfrutam de estabilidade e representam somente associados, por isso não celebram negociação coletiva. Assim sendo, as entidades sindicais possuem maior representação e prerrogativas diferenciadas. ${ }^{69}$

(STF - Súmula n. 677) "Até que lei venha a dispor a respeito, incumbe ao Ministério do Trabalho proceder ao registro das entidades sindicais e zelar pela observância do princípio da unicidade." (Sessão Plenária de 24/09/2003)

${ }^{66}$ MARTINS, Sergio Pinto. Direito do Trabalho. 29.ed. São Paulo: Atlas, 2013. p. 788-789.

${ }^{67}$ BARROS JUNIOR, Cássio de Mesquita. Registro de entidade sindical. In: MANNRICH, Nelson.

(Coord.) Atualidades do direito do trabalho: anais da academia nacional de direito do trabalho. São Paulo: LTr, 2012. p. 316.

${ }^{68}$ MASSONI, Túlio de Oliveira. Sindicatos: criação e registro. In: SANTOS, Enoque Ribeiro dos; SILVA, Otávio Pinto e. (Coord.) Temas controvertidos do direito coletivo do trabalho no cenário nacional e internacional. São Paulo: LTr, 2006. p. 173

${ }^{69}$ BARROS, Alice Monteiro. Curso de direito do trabalho. 5.ed. São Paulo: LTr, 2009. p. 1241. 
Na Itália, a Carta del Lavoro (1927) dispunha acerca da organização sindical e profissional livre, desde que devidamente reconhecida e submissa ao Poder Estatal. Em 1947, a Constituição do país proibiu a imposição de obrigações às entidades sindicais, exceto o registro civil nos cartórios.

Portanto, o registro tem por escopo a determinação de um controle de legitimidade, mas não de mérito, atribuindo ao ente personalidade jurídica de direito privado. ${ }^{70}$ Diante disso, não há impedimentos à instituição de sindicatos considerados entes de fato, podendo negociar e estar em juízo representando seus filiados. ${ }^{71}$

No ordenamento jurídico espanhol, é notável certa similitude com 0 modelo italiano, visto que a Constituição de 1978 prevê a livre criação e exercício dos sindicatos e das associações de trabalhadores. Contudo, por força da Lei Orgânica de Liberdade Sindical n. 11/1985, art. 7ํㅜ a concretização da personalidade e a plena capacidade de agir estão adstritas ao depósito dos seus estatutos, por meio dos seus dirigentes no devido órgão público.

Conquanto os tribunais superiores brasileiros não tivessem resolvido 0 problema interpretativo do registro sindical, o Comitê de Liberdade Sindical leciona:

[...] si bien los fundadores de un sindicato tienen que observar los requisitos de publicidad u otros análogos que pueden regir de acuerdo con determinada legislación, tales requisitos no deben equivaler prácticamente a una autorización previa ni constituir um obstáculo para la creación de una organización hasta el punto de constituir em los hechos una prohibición pura y simple. Aun cuando el registro sea facultativo, si de él depende que las organizaciones puedan gozar de los derechos básicos para poder "fomentar y defender los intereses de sus miembros", el mero hecho de que en tales casos la autoridad encargada de la inscripción goce del derecho discrecional de denegarla conduce a una situación que apenas diferirá de aquellas en que se exija una autorización previa. ${ }^{72}$

Sendo assim, não há que se falar em intromissão na formação dos sindicatos ou em prática de antissindicalidade. $O$ registro das entidades sindicais

\footnotetext{
${ }^{70}$ GALANTINO, Luisa. Diritto Sindicale. Torino: G. Giappichelli Editore, 1996. p. 09

${ }^{71}$ NASCIMENTO, Amauri Mascaro (2012), op. cit., p. 217.

${ }^{72}$ OIT. La libertad sindical. Recopilación de decisiones y princípios del Comité de Libertad Sindical del Consejo de Administración de la OIT. 5.ed. rev. Ginebra: Oficina Internacional del Trabajo, 2006. Párrafo 272. p.61.
} 
é um mero requisito de publicidade, que não pode ser confundido com um ato discricionário do poder público.

\subsubsection{Liberdade de organização}

Quando uma entidade adquire personalidade sindical, torna-se apta a defender os interesses individuais e coletivos de uma categoria, independente de prévia filiação, desde que relacionados às atividades profissionais ou econômicas. Sendo assim, são Ihes atribuídas determinadas funções, ou melhor, prerrogativas que a singularizam em relação a uma simples associação profissional. Ademais, tal concessão deve ser compreendida como um encargo a ser cumprido.

No magistério de José Martins Catharino: "órgão sem função é um traste, estático, sem serventia, o que contraria sua própria destinação dinâmica. Órgão sem meios ou instrumentos teleológicos está fadado à atrofia e ao desaparecimento". 73

As principais funções das organizações sindicais estão previstas, especialmente, nos artigos 513 e 514 da CLT, quais sejam: representativa, regulamentar, arrecadatória e assistencial. Ademais, há as polêmicas funções econômica e política.

Todavia, a disposição celetista acerca dos objetivos, prerrogativas e outros caracteres inerentes às entidades sindicais brasileiras costumam sofrer admoestação, sobretudo, porque a "lei brasileira une prerrogativas, fins concretos, objetivos díspares e conceitos gerais para conseguir caracterizar os sindicatos. Esta confusão tem gerado em grande parte perda de brilho à concepção das organizações, levando-as a serem organismos de caráter corporativo e de faculdades limitadas". 74

No que diz respeito à função econômica, é vedada expressamente pela CLT, assim: "Às entidades sindicais, sendo-Ihes peculiar e essencial a atribuição representativa e coordenadora das correspondentes categorias ou

${ }^{73}$ CATHARINO, José Martins, op. cit., p. 152.

${ }^{74}$ CABANELLLAS, Guillermo (1946), op. cit., p. 271-272. 
profissões, é vedado, direta ou indiretamente, o exercício de atividade econômica" (art. 564). Por sua vez, a função política é vedada no art. 521 do diploma celetista: “d) proibição de quaisquer atividades não compreendidas nas finalidades mencionadas no art. 511, inclusive as de caráter políticopartidário".

Mauricio Godinho Delgado informa que tais dispositivos da CLT não foram recepcionados pela Constituição Federal de 1988, pois restringem a liberdade de associação e a autonomia sindical. No caso do exercício da atividade econômica, deve ser analisada como um fator positivo, já que favorece a execução das suas funções de pessoa jurídica de direito privado. Nesse contexto afirmativo, há que se observar as questões de aparência exclusivamente políticas, uma vez que elas poderão influir no cotidiano das relações de trabalho. ${ }^{75}$

Além disso, o caráter político não nasce dentro do sindicato, vem do exterior. Os sindicatos são organismos puramente profissionais, cujos membros podem almejar individualmente fins políticos. Em regra, os partidos políticos buscam a força coletiva das organizações sindicais, as quais não se afastam do seu viés apolítico, desde que mantenham sua autonomia. ${ }^{76}$

A função representativa está disposta no art. 513, alínea a, da CLT: "representar, perante as autoridades administrativas e judiciárias, os interesses gerais da respectiva categoria ou profissão liberal ou interesses individuais dos associados relativos á atividade ou profissão exercida". Ademais, o art. $8^{\circ}$, III da CF reforça a defesa singular e coletiva nos referidos âmbitos.

À prerrogativa em comento são concedidas distintas dimensões, destacando-se: a privada, responsável pelo estabelecimento de relações entre a classe de trabalhadores e o grupo patronal; a administrativa, buscando 0 relacionamento com o Estado e visando à solução de entraves; a pública, almejando o contato e o apoio da sociedade civil; e a judicial, por meio da atuação direta em prol dos membros da categoria perante o Poder Judiciário. ${ }^{77}$

Nesse sentido, "a representação sindical diz respeito a uma série de fenômenos que não correspondem a um conceito unívoco, pois como

\footnotetext{
75 DELGADO, Mauricio Godinho, op. cit., p. 1379.

${ }^{76}$ CABANELLLAS, Guillermo (1946), op. cit., p. 259.

77 DELGADO, Mauricio Godinho, op. cit., p. 1377-1378.
} 
representante o sindicato atua os diferentes setores das relações coletivas de trabalho". 78

Quanto à função regulamentar ou negocial ou normativa, esta consiste na elaboração de normas coletivas para regular ou disciplinar as relações individuais de trabalho, cujo processo se dá por meio de negociações coletivas, tendo como resultado a convenção ou o acordo coletivo de trabalho, dos quais o conteúdo integrará os respectivos contratos laborais.

A negociação coletiva tem por objeto a criação, modificação ou manutenção das condições de trabalho. ${ }^{79} \mathrm{O}$ sindicato de empregados é compelido a participar de todos os processos de normatização, enquanto a entidade patronal somente das convenções. Igualmente à representação sindical, as conseqüências da prerrogativa negocial não estão adstritas aos membros filiados, é extensiva a todos (categoria) dentro do raio de atuação do sindicato.

No que tange à assistência sindical, basicamente é a prestação de serviços aos associados, a $\mathrm{CLT}^{80}$ elenca alguns serviços e os trata como deveres por parte das entidades sindicais, destacam-se os serviços de natureza médica, educacional, hospitalar e ambulatorial. Entretanto, "são atribuições, para alguns, impróprias, que desviam o sindicato do seu papel principal e que devem ser exercidas pelo Estado, e não pelo sindicato". 81

A função assistencial estudada não se confunde com a função educacional das entidades sindicais. A finalidade educativa reflete a imperiosidade dos sindicatos em estimularem "a formação sindical que propicie uma reflexão coletiva sobre carências e problemas comuns". Tal processo reflexivo faz-se eminente diante dos novos contornos adquiridos pelas relações

\footnotetext{
${ }^{78}$ SILVA, Walküre Lopes Ribeiro da. Crise de representatividade e participação dos sindicatos em políticas ativas de emprego. 2001. 333 f. Tese (Professor Titular) - Faculdade de Direito, Universidade de São Paulo, São Paulo, 2001. p. 96.

${ }^{79}$ AROUCA, José Carlos (2006), op. cit., p. 288.

80 CLT, art. 514. "São deveres dos sindicatos: a) colaborar com os poderes públicos no desenvolvimento da solidariedade social; b) manter serviços de assistência judiciária para os associados; c) promover a conciliação nos dissídios de trabalho; d) sempre que possível, e de acordo com as suas possibilidades, manter no seu quadro de pessoal, em convênio com entidades assistenciais ou por conta própria, um assistente social com as atribuições específicas de promover a cooperação operacional na empresa e a integração profissional na Classe. Parágrafo único. Os sindicatos de empregados terão, outrossim, o dever de : a) promover a fundação de cooperativas de consumo e de crédito; b) fundar e manter escolas do alfabetização e pre-vocacionais."

${ }^{81}$ NASCIMENTO, Amauri Mascaro (2012), op. cit., p. 322.
} 
laborais, especialmente em decorrência de formas prejudiciais de utilização da mão de obra, como o trabalho escravo e o subemprego em massa. Incumbe aos sindicatos promoverem o despertamento dos trabalhadores e empregadores à liberdade sindical em todas as suas nuances, compreendendo sua importância no fomento da dignidade humana. ${ }^{82}$ Além disso, a liberdade sindical necessita ser interiorizada pelos atores sociais, conforme assevera Tamira Maira Fioravante:

[...] enquanto a liberdade sindical não for encarada pelos sujeitos da relação de trabalho como um bem essencial à criação e à manutenção de relações de trabalho produtivas e simultaneamente emancipadoras, de muito pouco adiantará o reconhecimento jurídico da mesma. ${ }^{83}$

A formação consciencial do trabalhador importa no fortalecimento do movimento sindical e, consequentemente na repressão da descoletivização decorrente da descrença do papel dos agrupamentos, frequentemente justificada pela inexpressividade representativa. Além disso, a metodologia aludida, outrossim, poderá impulsionar a visualização da função negocial como instrumento de efetivação dos direitos humanos fundamentais da classe trabalhadora, sem a dependência da ação do legislador ordinário, diversamente do plano atual externado por sindicatos apáticos que pactuam negociações coletivas fracas.

Alusivo à função arrecadatória, Guillermo Cabanellas a denomina poder tributário e lhe atribui o objetivo de servir para o sustento da entidade. Recorda também, a confusão entre o poder tributário sindical e o poder tributário do Estado, este é obrigação de todos os indivíduos para que possam usufruir de benefícios comuns, enquanto o primeiro repercute exclusivamente aos membros da categoria, estes, por vezes, sentem-se constrangidos em custear as despesas de um órgão sem lograr as vantagens relatadas. ${ }^{84}$

Dessa maneira, a supracitada prerrogativa está associada à produção das receitas do órgão sindical e é traduzido pelo poder de impor contribuições aos

\footnotetext{
${ }^{82}$ FIORAVANTE, Tamira Maira. Sindicato, educação e liberdade. São Paulo: LTr, 2008. p. 105;125-126. ${ }^{83}$ Ibid., p. 09.

${ }^{84}$ CABANELLLAS, Guillermo (1946), op. cit., p. 322-323.
} 
membros da categoria representada. No Direito brasileiro, tal imposição é exteriorizada pelas seguintes cobranças: contribuição sindical, contribuição confederativa, contribuição assistencial e mensalidade sindical.

A contribuição sindical é um instituto que descende do antigo imposto sindical preconizado pela Constituição de 1937 e Decreto-Lei 2.377/40. Atualmente, está prevista nos artigos 578 a 610 da $\mathrm{CLT}^{85}$, assim como no art. 8o, inciso IV da Constituição Federal. Segundo interpretação dos referidos dispositivos legais, trata-se de uma cobrança anual, correspondente à remuneração de um dia de trabalho quando empregados, e de acordo com o capital social da empresa para os empregadores, realizada a todos os pertencentes à categoria profissional e econômica, tal como o trabalhador liberal, em prol do sindicato representativo.

Ademais, a sua disposição legal confere-Ihe condição de tributo, consequentemente, dotada de obrigatoriedade, por isso o pagamento independe do livre arbítrio dos destinatários. Inclusive, no caso dos empregados, o desconto é efetuado diretamente pelo empregador na remuneração do mês de março, ou seja, mesmo que houvesse oposição, esta fugiria do controle daqueles.

Desse modo, apresenta todos os requisitos de um tributo, definidos no art. 3ำ do Código Tributário Nacional brasileiro, assim: "é toda prestação pecuniária compulsória, em moeda ou cujo valor nela se possa exprimir, que não constitua sanção de ato ilícito, instituída em lei e cobrada mediante atividade administrativa plenamente vinculada".

Em seguida, tem-se a contribuição confederativa, de acordo com a denominação, destina-se à manutenção do sistema confederativo como um todo: sindicatos, federações e confederações. Trata-se de uma obrigação consensual, portanto, necessita da manifestação de vontade dos interessados, ou seja, os associados. Não se pode olvidar que a fixação do quantum da contribuição ocorre em assembleia geral, por isso, não há compulsoriedade na sua cobrança e,

\footnotetext{
${ }^{85}$ CLT, art. 578 "As contribuições devidas aos Sindicatos pelos que participem das categorias econômicas ou profissionais ou das profissões liberais representadas pelas referidas entidades serão, sob a denominação do "imposto sindical", pagas, recolhidas e aplicadas na forma estabelecida neste Capítulo."
} 
consequentemente vincula-se apenas os indivíduos filiados. ${ }^{86}$ Recebe amparo legal do art. $8^{\circ}$, inciso IV da CF. ${ }^{87}$

A contribuição assistencial também chamada de taxa de reforço sindical e contribuição de fortalecimento sindical é convencionada pelas partes e pode ser cobrada somente dos empregados sindicalizados, conforme art. 513, e, da CLT. A autorização para cobrança advém de acordo ou convenção coletiva de trabalho. ${ }^{88}$

Para tanto, o STF editou a súmula n. 666 e o TST o precedente normativo n. 119, dispondo acerca da desnecessidade do pagamento pelos pertencentes às categorias econômicas e profissionais, mas não sindicalizados. ${ }^{89}$

Por fim, os estatutos das entidades sindicais podem dispor acerca do recolhimento da mensalidade sindical, reservada à manutenção dos serviços oferecidos e paga unicamente pelos associados.

Os valores pagos a título de contribuições deveriam ser revertidos à manutenção do sistema sindical e ao bem estar dos seus representados. Todavia, em dadas situações, destinam-se apenas à sustentação de organizações sindicais com poder de representação débil e serviços assistenciais de qualidade discutível.

${ }^{86}$ Sergio pinto Martins $830-833$.

${ }^{87} \mathrm{CF}$, art. $8^{\circ}$, inciso IV - "a assembléia geral fixará a contribuição que, em se tratando de categoria profissional, será descontada em folha, para custeio do sistema confederativo da representação sindical respectiva, independentemente da contribuição prevista em lei;"”

${ }^{88}$ DELGADO, Mauricio Godinho. p. 836-839.

${ }^{89}$ STF, súmula n. 66, "A contribuição confederativa de que trata o art. 8o, iv, da Constituição, só é exigível dos filiados ao sindicato respectivo."

TST. PRECEDENTE NORMATIVO N. 119 CONTRIBUIÇÕES SINDICAIS - INOBSERVÂNCIA DE PRECEITOS CONSTITUCIONAIS - (nova redação dada pela SDC em sessão de 02.06.1998 homologação Res. 82/1998, DJ 20.08.1998. "A Constituição da República, em seus arts. 5, XX e 8o, V, assegura o direito de livre associação e sindicalização. É ofensiva a essa modalidade de liberdade cláusula constante de acordo, convenção coletiva ou sentença normativa estabelecendo contribuição em favor de entidade sindical a título de taxa para custeio do sistema confederativo, assistencial, revigoramento ou fortalecimento sindical e outras da mesma espécie, obrigando trabalhadores não sindicalizados. Sendo nulas as estipulações que inobservem tal restrição, tornam-se passíveis de devolução os valores irregularmente descontados." 
2.2.5 Unicidade sindical e base territorial mínima

A liberdade de fundação dos sindicatos está expressa em diversas normas da OIT, mas o delineamento dessa prerrogativa dependerá do modelo de organização adotado por cada Estado, seja por meio da pluralidade sindical ou a consequente unidade espontânea, bem como da unicidade.

Na pluralidade sindical, o cenário favorece e a legislação nacional não proíbe a criação de incontáveis sindicatos destinados à representação do mesmo público, ou seja, não se obsta a existência de quantas sejam as unidades de idêntica classe de trabalhadores ou empregadores.

A pluralidade é verificada, especialmente em países de grande desenvolvimento econômico como a Itália, cujo sistema sindical não sofre regulação estatal com ditames dos requisitos necessários à formação das entidades ou a imposição de ideologias e objetivos. As características ou o tipo de pluralismo variam de acordo com a história econômica, social, cultural e institucional de cada país, assim como nas relações de maior ou menor integração dos sindicatos com o Estado. ${ }^{90}$

No interior do sistema plúrimo ocorre a unidade, que consiste no agrupamento natural de pessoas (empregados ou empregadores) na mesma entidade sindical, assim sendo, não há a imposição legal para tal formação, decorre simplesmente da vontade dos indivíduos pertencentes aos grupos.

Tomás Sala Franco e Ignacio Albiol Montesinos explicam que a existência do pluralismo e da unidade em um mesmo regime de liberdade sindical somente é possível com grande esforço. Tal fato é corroborado pela Convenção n. 87 da OIT, que não recomenda nenhuma das figuras, apenas discorre acerca da vontade e da liberdade de escolha. ${ }^{91}$

A unidade sindical é classificada em duas categorias: unidade orgânica e unidade de ação. A primeira ocorre quando há um sindicato organizado e de autoridade única. Esse unitarismo é manifestado mediante um procedimento legal

${ }^{90}$ CARUSO, Bruno. Le relacione sindicali. Torino: G. Giappichelli Editore, 2004. p. 34-35.

${ }^{91}$ FRANCO, Tomás Sala; MONTESINOS, Ignacio Albiol. Derecho sindical. Valentia: Tirant Lo Blanch, 1994. p. 76. 
ou imposto pela ordem estatal, neste caso, vai de encontro aos preceitos de liberdade sindical plena, uma vez que o Poder Público poderá impor o sindicato único, de filiação obrigatória. ${ }^{92}$

Esse método equivale à unicidade sindical brasileira, a qual a legislação impõe a fixação de apenas um órgão representativo por classe econômica ou profissional a dada extensão geográfica, correspondente no mínimo a área de um município.

Ademais, há a unidade orgânica voluntária, alcançada por meio da aquiescência de filiados e dos sindicatos. No entanto, a heterogeneidade da classe obreira, decorrente da ausência de consciência sindical, assim como da divisão de trabalho (manual, intelectual ou industrial) e da desigualdade no tratamento entre os atores sociais (por exemplo, a desvalorização da mão de obra feminina com relação à masculina) dificultam o processo unitário. ${ }^{93}$

A segunda categoria refere-se à unidade de ação, baseada na colaboração entre os vários sindicatos organizados de forma independente, cuja exteriorização ocorre por meio de um procedimento legal ou voluntário. No que diz respeito à unidade de ação voluntária, ocorre a partir de acordos intersindicais. Enquanto no âmbito da legalidade, trata-se do estabelecimento de instrumentos estatais aptos a enfrentar o sistema pluralista. Contudo, isso poderá significar um ataque à autonomia ou independência sindicais, porquanto manterá/fixará o monopólio ou oligopólio de diversos sindicatos. Em decorrência disso, emerge uma função dúbia: o apoio à implantação e desenvolvimento das entidades sindicais ou a redução da liberdade de ação, por exemplo, na concessão de privilégios a um sindicato em prejuízo de outro. ${ }^{94}$

Esses mecanismos têm por escopo a suavização da pluralidade sindical, tornando-a disciplinada. Um dos meios em destaque é do "conceito de sindicato mais representativo", o qual importa na atuação de apenas um sindicato (o mais representativo). Para tanto, há a fixação de requisitos legais para a

\footnotetext{
${ }^{92}$ FRANCO, Tomás Sala; MONTESINOS, Ignacio Albiol, op. cit., p. 76.

${ }^{93}$ Ibid.

${ }^{94}$ Ibid., p. 77-78.
} 
consagração da entidade, como o número de filiados, montante de contribuições e antiguidade. ${ }^{95}$

Walküre Lopes Ribeiro da Silva informa as principais críticas da doutrina com relação à aferição dos critérios de maior representatividade, como a de que estaria mais no âmbito da presunção que no plano real. Diante disso, ressalta-se a participação da jurisprudência "de que a maior representatividade deve ser constatada no tempo, pois a entidade sindical pode preencher os requisitos necessários em um dado período e deixar de atendê-los em outro". ${ }^{96}$

No Brasil, o pluralismo pôde ser observado na Constituição de 1934: "A lei assegurará a pluralidade sindical e a completa autonomia dos sindicatos". Entretanto, foi revogada pela Carta outorgada de 1937 durante o golpe de Estado promovido por Getúlio Vargas.

Atualmente, a multiplicidade de organizações em uma mesma base territorial somente é verificada quanto às associações civis, visto que não possuem personalidade sindical e se limitam a defender os interesses dos seus associados; ademais, não compartilham das prerrogativas dos sindicatos.

Desse modo, o sindicalismo brasileiro adota a unicidade como modelo de organização, também conhecida sob a denominação de sindicato único. De acordo com Arion Sayão Romita, a expressão comporta três classes: a primeira, imposta pelos regimes corporativistas, como o da Itália de Mussolini e o Brasil atual; a segunda, dos países formadores do bloco socialista (leste europeu); e a terceira, composta pelos Estados cuja base é organizada por meio da unidade espontânea e sem intervenção estatal, como o Reino Unido, a Austrália e a Alemanha. ${ }^{97}$

Consoante Mauricio Godinho Delgado, a unicidade equivale à:

[...] previsão normativa obrigatória de existência de um único sindicato representativo dos correspondentes obreiros, seja por empresa, seja por profissão, seja por categoria profissional. Trata-se da definição legal imperativa do tipo de sindicato passível de organização na sociedade, vedando-se a existência de entidades sindicais concorrentes ou de

\footnotetext{
${ }^{95}$ NASCIMENTO, Amauri Mascaro (2012), op. cit., p. 194

${ }^{96}$ SILVA, Walküre Lopes Ribeiro da (2001), op. cit., p. 103-104.

${ }^{97}$ ROMITA, Arion Sayão. Organização sindical. Revista Síntese Trabalhista. Porto Alegre, v. 15, n. 171 , p. $09-24$, set. 2003. p. 12.
} 
outros tipos sindicais. É, em síntese, o sistema de sindicato único, com monopólio de representação sindical dos sujeitos trabalhistas. ${ }^{98}$

O modelo de unidade obrigatória mostra-se inadequado às modificações presentes nas relações de trabalho, especialmente com a inserção de recursos tecnológicos que as tornam cada vez mais dinâmicas. Além disso, outros atores sociais devem ser considerados na formação do sindicalismo, como os aposentados e os desempregados. O sistema em comento está conectado às práticas ultrapassadas do corporativismo italiano. Ademais, pode se considerar como uma forma de antissindicalidade promovida pelo Estado, afinal, não há liberdade de escolha, o indivíduo deve se contentar com as entidades representativas existentes.

A Constituição Federal de 1988, no artigo 8ํㅡㄹ inciso II, dispõe sobre a livre associação profissional e sindical, mas limitada a representação por categoria profissional ou econômica, em qualquer graduação, à base territorial mínima, equivalente a área não inferior ao tamanho de um município.

Nesse sentido, o artigo 516 da Consolidação das Leis do Trabalho CLT reforça a unitarismo legal: "Não será reconhecido mais de um Sindicato representativo da mesma categoria econômica ou profissional, ou profissão liberal, em uma dada base territorial."

A partir de tal normatização torna-se evidente o predomínio de uma estrutura heterogênea, isto é, possui traços simultâneos de um regime de liberdade (livre associação) e de características corporativistas (limitação territorial). Essa herança intervencionista procede do sistema italiano de Mussolini, especialmente de diplomas como a Carta del Lavoro (1927), fonte de inspiração para a redação da CLT (1943). Para alguns, uma verdadeira cópia do mencionado documento italiano, período em que os sindicatos eram uma extensão ou se subordinavam ao poderio estatal.

No que diz respeito ao significado da expressão "base territorial", consiste no espaçamento geográfico segundo o qual as organizações sindicais deverão respeitar para exercer o direito de fundação e, consequentemente o

${ }^{98}$ DELGADO, Mauricio Godinho, op. cit., p. 1368. 
direito de representação. Em decorrência dessa característica, o sistema nacional não viabiliza a criação de entidades sindicais no âmbito das empresas.

A unicidade sindical é uma marca da atual estrutura constitucional corporativa, que ocasiona a inoperatividade dos sindicatos, resumindo sua existência a aspectos formais (não atuantes) e impedindo um sindicalismo espontâneo, autêntico e representativo. ${ }^{99}$

Em 1966, J. M. Verdier já acentuava que "a unidade imposta não tem a virtude de apagar os antagonismos ou as divergências ideológicas que somente a unificação voluntária e livre pode permitir superar, como ocorre em certos países". 100

C. A. Barata Silva externa seu posicionamento favorável ao pluralismo comparando o sindicato único com um partido político único: "Se quiser sindicalizar poderá fazê-lo, mas será neste ou naquele sindicato ou se quiser participar da vida política, pode participar, mas será em tal partido". A imposição da sindicalização única não garante a unidade, pode, inclusive, elevar os níveis de abstenção no cotidiano sindical, por sua vez, a pluralidade estimularia as entidades sindicais a proporcionar diversas vantagens aos associados. ${ }^{101}$

Segundo Antônio Rodrigues de Freitas Júnior, a unicidade sindical necessita ser analisada em um conjunto, pois a particularização remete a incertezas, uma vez que a extinção do citado modelo organizacional por si só não garante a renúncia ao corporativismo ou a mera inserção do sistema pluralista seja capaz de assegurar a liberdade sindical de maneira efetiva. ${ }^{102}$

Compartilha-se o entendimento de que a unicidade sindical não seja o melhor modelo de organização para o Brasil. Primeiramente, por causa da supracitada mitigação da liberdade sindical; em segundo lugar, porque denota o sucateamento do sistema das relações trabalhistas. Ademais, já não se admite a falácia de que o monisto freia a expansão descontrolada de entidades sindicais,

${ }^{99}$ MASSONI, Túlio de Oliveira. Sindicatos: criação e registro. In: SANTOS, Enoque Ribeiro dos; SILVA, Otávio Pinto e. (Coord.) Temas controvertidos do direito coletivo do trabalho no cenário nacional e internacional. São Paulo: LTr, 2006. p. 173.

${ }^{100}$ VERDIER, J. M. Syndicats-traité du droit du travail, 1966 apud FERRARI, Irany. Unidade e pluralidade sindicais. In: ROMITA, Arion Sayão (Coord.). Sindicalismo. São Paulo: LTr, 1986. p. 67.

${ }^{101}$ Barata Silva, C. A. Liberdade sindical - unidade e pluralidade. In: TEIXEIRA FILHO, João de Lima. Relações coletivas de Trabalho. Estudos em homenagem ao Ministro Arnaldo Süssekind. São Paulo: LTr, 1989. p. 310-311.

${ }^{102}$ FREITAS JÚNIOR, Antônio Rodrigues de. Sindicato: domesticação e ruptura. Um estudo de representação sindical no direito brasileiro. São Paulo: Ordem dos Advogados do Brasil, 1989. p. 157. 
notoriamente, atesta-se um crescimento vertiginoso de entes, especialmente em decorrência do desmembramento de categorias. Por outro lado, não se defende de forma utópica a pluralidade como a salvação de todos os problemas enfrentados pelo sindicalismo brasileiro, cujas raízes são mais profundas, como o descrédito do trabalhador ao movimento sindical.

2.2.6 Critério de agregação de trabalhadores e empregadores: categoria e paralelismo sindical

O critério de agregação de trabalhadores e empregadores é o instrumento manejado pelos sindicatos para o agrupamento dos seus representados, mas esses mecanismos podem variar de acordo com regime sindical organizativo adotado por cada país, consequentemente, afetará a propagação do direito à liberdade sindical plena, tornando-o mitigado ou inócuo.

Uma entidade pode reunir os indivíduos que exerçam a mesma atividade laboral. Essa ordenação é denominada sindicato por ofício ou profissão, por exemplo, professores, músicos profissionais, aeronautas. No Brasil, esse agrupamento é conhecido por categoria profissional diferenciada, cuja união dos empregados ocorre em razão de estatuto profissional especial ou condição de vida singular, consoante 0 art. $511, \S^{3} 3^{\circ}$ da CLT, com o devido respeito à extensão territorial exigida. Em decorrência de o liame existir por causa do ofício, não há a criação de sindicatos diferenciados para os empregadores.

Há também a agregação no âmbito da empresa, e o vínculo surge devido ao trabalho exercido para o mesmo empregador, seja em setores ou na totalidade do empreendimento. Notavelmente, essa situação não se aplica ao contexto brasileiro, visto que a legislação exige a área mínima de um município para a fundação de uma organização sindical. No Brasil, o instituto que mais se aproxima do sindicato por empresa é o da eleição de um representante no local de trabalho para intermediar o entendimento com o empregador, conforme art. 11 da $\mathrm{CF}$, contudo, no entanto, tal representação não possui atributos sindicais. 
A agremiação sindical por empresa é verificada, principalmente, em grandes empresas e recorrente em países como Itália e Estados Unidos. No que diz respeito aos pequenos estabelecimentos empresariais, não utilizam o instituto com frequência, porquanto poderão buscar outros métodos simplificados, como as comissões ou seções sindicais. A principal desvantagem dessa formação é a possibilidade de cooptação do sindicato pelo empregador; por outro lado, há a vantagem de facilitar a comunicação entre entidade sindical e os seus representados. ${ }^{103}$

No âmbito brasileiro, a herança do corporativismo italiano do século XX não se restringe à unicidade, estão presentes outras particularidades, como a agregação dos trabalhadores nos sindicatos por meio de categorias.

Consoante Octávio Bueno Magano, "categoria é o conjunto de pessoas que, ligadas pela solidariedade resultante da identidade de condições de vida, perseguem interesses profissionais comuns". ${ }^{104}$

Para Arion Sayão Romita, a categoria é "determinada pelos modos de exteriorização da autonomia coletiva, principalmente mercê da negociação. A noção sociológica de categoria expressa-se como coletividade caracterizada pelo conjunto dos destinatários de determinada organização". ${ }^{105}$

O art. 577, da CLT, apresenta o quadro oficial das categorias que não é mais revisto e atualizado, já que a formação da categoria não mais advém do alvitre do Estado. Trata-se de prerrogativa atribuída aos sindicatos, por isso, a denominação anterior categorias a priori foi substituída por categorias a posteriori. "Antes a categoria precedia ao sindicato e agora o sindicato precede ou nasce com a categoria. Foi a nossa maior mudança". ${ }^{106}$

Segundo o art. 511, $\S 1^{\circ}$ e $2^{\circ}$ da CLT, as categorias dividem-se em: econômica, que consiste na "solidariedade de interesses econômicos dos que empreendem atividades idênticas, similares ou conexas, constitui o vínculo social básico", e profissional, formada a partir da "similitude de condições de vida oriunda da profissão ou trabalho em comum, em situação de emprego na

\footnotetext{
${ }^{103}$ NASCIMENTO, Amauri Mascaro (2012), op. cit., p. 211-212.

104 MAGANO, Octavio Bueno. Direito coletivo do trabalho. 3.ed. São Paulo: LTr, 1993. v. 3. p. 106.

${ }^{105}$ ROMITA, Arion Sayão (2003), op. cit., p. 14.

${ }^{106}$ NASCIMENTO, Amauri Mascaro. Problemas que dificultam a reforma sindical. LTr: revista

legislação do trabalho. São Paulo, v.71, n.6, p.647-53, jun. 2007. p. 653.
} 
mesma atividade econômica ou em atividades econômicas similares ou conexas". À vista disso, constata-se o que Octávio Bueno Magano denominou "paralelismo simétrico". 107

Assim, a formação da representação da classe trabalhadora, em regra, é dependente da atividade econômica preponderante do empregador, já que para cada categoria econômica existente, haverá uma respectiva categoria profissional. Essa metodologia é extremamente prejudicial ao exercício da liberdade sindical, em razão da impossibilidade da união espontânea de trabalhadores, como a que tem origem na identidade de profissões.

O paralelismo sindical não impede, desde que respeitada a territorialidade mínima, o desmembramento de uma categoria, seja profissional ou econômica. Geralmente, isso ocorre a partir de entidades sindicais de grande extensão representativa, como a fragmentação de uma organização de amplitude estadual em um ou mais sindicatos de domínio municipal.

A indivisibilidade da categoria trata-se de um princípio, enquanto a divisibilidade um fato. Dessa maneira, a primeira assertiva correlaciona-se ao plano teórico ou abstrato, ou melhor, à unidade absoluta da categoria; à medida que a divisão está concatenada ao direito de livre sindicalização (não restrito ao ingresso ou abstenção da prática sindical). Além disso, a categoria é constituída por interesses coletivos e individuais, bem como de atores sociais (o empregado e o empregador) concebidos na sua singularidade, com ideias discrepantes e, por vezes, conflituosas, consequentemente, levando à partição. ${ }^{108}$

O fracionamento dos sindicatos de abrangência intermunicipal é justificado, outrossim, pelo intuito de preservar a homogeneidade do grupo. Destarte, criam uma entidade em cada um dos municípios pertencentes à base original, cuja atuação, em determinados casos, fica a cargo de "órgãos fantasmas", resultando em ineficiência. ${ }^{109}$

A fragmentação ocasionou o aumento desenfreado do número de sindicatos, mesmo obedecendo ao modelo de organizacional de unicidade.

\footnotetext{
107 MAGANO, Octavio Bueno (1993), op. cit., p.109.

108 RUSSOMANO, Mozart Victor, op. cit., p. 82-83.

${ }_{109}$ MEIRELLES, Davi Furtado. Liberdade sindical: o modelo ideal. LTr: Revista Legislação do

Trabalho. São Paulo, v.74, n.5, p.542-52, maio. 2010. p. 544.
} 
Segundo os dados coletados pelo Ministério do Trabalho e Emprego ${ }^{110}$, em 2014, o Brasil atingiu o número de 15.520 sindicatos ativos, desse total: 10.539 sindicatos de trabalhadores e 4.981 sindicatos de empregadores, assim como 5 centrais sindicais. Tais números mostram-se paradoxais quando comparados a países que adotam o modelo de unidade, como a Alemanha, sua estrutura é composta de apenas 16 sindicatos e uma central sindical, a DGB.

Desse modo, resta evidente o aspecto retrocessivo da unicidade e da agregação por categorias, uma vez que não cumprem nem mesmo o papel principal para o qual foram adotados, qual seja: a limitação do número de entidades.

O enquadramento legal estatal por categorias, auferido da Itália, foi abandonado por lá desde a sua redemocratização. Mas, no território brasileiro, o modo pelo qual foi concebido, oportunizou sua subsistência, mesmo após modificações políticas e econômicas ocorridas pelo país. "Mais que uma opção política, o conceito de categoria passou a ser considerado um critério ontológico de organização sindical." Tal constatação evidencia-se imprecisa, já que o nascimento dos sindicatos não decorre da formação da categoria, e sim o oposto. ${ }^{11}$

\footnotetext{
${ }^{110}$ MINISTÉRIO DO TRABALHO E EMPREGADO, 2014. Disponível em: <http:// www.mte.gov.br>.

${ }^{111}$ SANTOS, Ronaldo Lima dos (2012), op. cit., p. 219.
} 


\section{CAPÍTULO 3 REFORMA SINDICAL BRASILEIRA E OS PRINCÍPIOS DE LIBERDADE SINDICAL}

\subsection{Reforma sindical brasileira: imperiosidade}

$\mathrm{Na}$ última década, tem ressoado o discurso imponente de que o ordenamento brasileiro carece de modificação em diversos setores, comumente argúi-se a revisão do sistema político e tributário, assim como uma reforma sindical completa do antigo regime. Mas, visivelmente, os esforços de mudança esbarram em obstáculos diversificados, como a inércia do legislador e o desinteresse de grupos acomodados e satisfeitos com o modelo vigente. Ante a temática em desenvolvimento, cumpre tecer comentários exclusivamente sobre as transformações ambicionadas ao sindicalismo.

O modelo sindical brasileiro atual, com mínimas modificações desde a sua criação, notoriamente, não se adéqua ao cotidiano laboral contemporâneo. Antônio Rodrigues de Freitas Junior aponta dois fatores à continuidade desse sistema díspar:

\footnotetext{
[...] dispersão das forças políticas desejosas de sua superação (imersas em diferenças doutrinárias e duvidosamente motivadas em abraçar processos de mudança de resultado incerto), e coesão daquelas que se alimentam do sistema sindical vigente (marcadamente pragmáticas e altamente motivadas para a defesa da manutenção dos privilégios e prerrogativas em que se sustentam. ${ }^{1}$
}

Nesse sentido, Arion Sayão Romita recorreu ao mecanismo de parábolas para explicar a permanência (conservadorismo) das condições sindicais brasileiras. Inicialmente, reproduziu notícia acerca da Conferência Estadual do Trabalho realizada no Rio de Janeiro em 2003, formada por integrantes de diversas categorias, especialmente representantes do Ministério

\footnotetext{
${ }^{1}$ FREITAS JÚNIOR, Antônio Rodrigues. A negociação coletiva do trabalho e o projeto de reforma sindical de 2005. Revista do Departamento de Direito do Trabalho e da Seguridade Social, São Paulo, v.1, n.1, p.9-14, jan./jun. 2006. p. 11.
} 
Público, empregados e empregadores. O encontro resultou no entendimento de que a conjuntura deveria permanecer intacta, ou seja, preservando-se a unicidade sindical e a contribuição sindical obrigatória, por exemplo. ${ }^{2}$

Em seguida, o autor apresentou uma alegoria, segundo a qual o senhor Pi Ti Liu detinha a posse de um bananal que não the auferia lucratividade, mas também não demandava trabalho. Incentivado por seu amigo pernambucano Severino, resolvera transformar o bananal em canavial. Para tanto, necessitaria consultar os primatas que ali residiam há mais de seis décadas. Depois de realizada a votação entre os símios, obteve-se o seguinte resultado: quatro votos favoráveis à mudança, visto que se tratava de macacos que não gostavam de bananas; e, dez mil votos contrários à proposta. ${ }^{3}$

Assim, a decisão majoritária foi acatada pelo proprietário, a qual resulta em três morais:

\begin{abstract}
Primeira moral da história: $\square$ Quem deseja transformar bananal em canavial não deve consultar macacos. Segunda moral da história: $\square \mathrm{O}$ proprietário do bananal não desejava de verdade transformá-lo em canavial. Terceira moral da história: $\square$ Com bananal que produz boas bananas para os macacos, não se deve mexer. ${ }^{4}$
\end{abstract}

A "árvore sindical" nacional é cultivada desde o Estado Novo e permanece em vigor. Paralelamente, o histórico constitucional mostrou-se incipiente com relação ao assunto, mesmo com os avanços da Constituição Federal de 1988. O cenário é marcado pela incoerência, tendo em vista a adoção concomitante de detalhes progressistas e conservadores, como a aplicação do princípio da liberdade sindical e, de forma oposta, a imposição da unicidade e o enquadramento por categorias. Mas, "uma coisa não pode ser e não ser ao mesmo tempo". 5

Enquanto no Brasil de 1943, compilava-se a Consolidação das Leis do Trabalho, espelhada na Carta del Lavoro; na Itália, remodelava-se o

\footnotetext{
${ }^{2}$ ROMITA, Arion Sayão. Parábola do bananal sindical brasileiro. Revista da Academia Nacional de Direito do Trabalho. São Paulo, v.12, n.12, p.57-8, 2004. p. 57.

${ }^{3}$ Ibid., p. 57-58.

${ }^{4}$ Ibid., p. 58.

${ }^{5}$ NASCIMENTO, Amauri Mascaro. Problemas que dificultam a reforma sindical. LTr: revista legislação do trabalho. São Paulo, v.71, n.6, p.647-53, jun. 2007. p. 647-648
} 
aparelhamento sindical; concedendo, por exemplo, a condição de entes de direito privado às organizações sindicais, o que resultou, especialmente em: liberdade de criação de entidades em todos os níveis, fim da agregação por categorias, existência simultânea de sindicatos de fato e outros dotados de personalidade jurídica, contratação coletiva articulada entre Confederações e sindicatos, assim como a punição de atos antissindicais. ${ }^{6}$

Inicialmente, o ordenamento italiano optou pela organização sindical com representatividade auferida pelas Confederações, com o intento de evitar a propagação desenfreada de entes de base, o que se evidenciou ineficiente à conjuntura. Por isso, em 1995, mediante um referendo destitui-se a mencionada

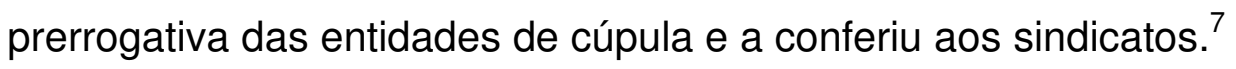

A construção de um "novo modelo sindical" não é diminuta à revisão dos excertos reacionários da estrutura existente, incumbe a implementação concomitantemente de garantias jurídicas à efetivação, organização e fortalecimento dos sindicatos. Desse modo, buscou-se a promoção concreta dos princípios da livre associação e da autonomia sindical. ${ }^{8}$

José Pastore afirma que a durabilidade de um sistema incute-se na adequação dos pactos presentes e vindouros, principalmente devido ao seu caráter de transitoriedade no "mundo do emprego" e no "mundo do trabalho"; assim, demandam-se ações que acolham os novos vínculos, diversamente do protecionismo predominante de relações subordinadas. Culturalmente, muitos optam pela exclusiva proteção legal e rechaçam a negociação. ${ }^{9}$

O trabalhador não deve ser eleito o responsável pela valorização da legislação em detrimento da negociação coletiva, essa característica descende da própria cultura sindical implantada por décadas, segundo a qual, muitos sindicatos sem expressividade logram pactos também inexpressivos, dialogando apenas condições mínimas já previstas no ordenamento. A elevação da negociação deve ser observada cautelosamente para que não incorra no desejo empresarial de flexibilizar as normas trabalhistas e, consequentemente, induzir à precarização

\footnotetext{
${ }^{6}$ NASCIMENTO, Amauri Mascaro (2007), op. cit., p. 648.

7 lbid., p. 649.

8 DELGADO, Mauricio Godinho. Curso de direito do trabalho. 12.ed. São Paulo: LTr, 2013. p. 1402.

9 PASTORE, José. Reforma sindical: para onde o Brasil quer ir? São Paulo: LTr, 2003. p. 12.
} 
das relações laborais. Ademais, deve-se negociar para melhorar e ampliar, e não para diminuir vantagens e condições.

Edésio Passos destaca a organização do movimento sindical brasileiro, mas indica alguns fatores que expõem deficiências estruturais dos agrupamentos de trabalhadores, quais sejam: ausência de entidades sindicais no âmbito da empresa, carência de planejamento estratégico acerca das pretensões de toda a classe representada, reduzido nível de associação em determinados campos, fragmentação corporativa, escassez de recursos financeiros de muitos entes. ${ }^{10}$

Márcio Túlio Viana realça um sindicato brasileiro frágil, sobretudo em decorrência do comando legal regulador e igualmente repressor. Corroborando com a assertiva, menciona outros fatos perquiridos pela Associação Nacional dos Magistrados da Justiça do Trabalho - ANAMATRA, quais sejam: a ausência de combate efetivo às condutas antissindicais, inexistência de representação sindical nos locais de trabalho, o espaçamento entre as entidades de bases e as de cúpula, o impedimento de contratos coletivos de maior amplitude, a manutenção da contribuição sindical forçada em ambientes marcados pela baixa representatividade. $^{11}$

Nesse ínterim, o autor questiona: "como o próprio sindicato está se vendo?". O sindicalismo creditava as atuais circunstâncias negativas exclusivamente ao incansável e repetido discurso do legado corporativista da Era Vargas, exteriorizado por: unicidade sindical, "imposto" sindical, poder normativo, enquadramento por categorias. Contudo, sob novas perspectivas, tal entendimento foi reformulado e a maioria das organizações percebeu que "a principal razão da fragilidade do movimento sindical não é a herança de Vargas, mas a nova forma de acumulação capitalista. É a estrutura, bem mais do que a circunstância". ${ }^{2}$

Gilnei M. Teixeira ressalta a imperiosidade de haver reciprocidade entre o sistema brasileiro de relações de trabalho e os novos contornos da economia, sociedade e tecnologia, "configuradoras de um novo mundo do

\footnotetext{
${ }^{10}$ PASSOS, Edésio. Reflexões e propostas sobre a reforma trabalhista e sindical. LTr: revista legislação do trabalho. São Paulo, v.67, n.5, p.519-35, maio. 2003. p. 532.

${ }^{11}$ VIANA, Márcio Túlio. A reforma sindical, entre o consenso e o dissenso. Revista do Tribunal Superior do Trabalho, Brasília, vol. 70, n. 2, p. 52-71, jul./dez. 2004. p. 54.

${ }^{12}$ lbid., p. 56.
} 
trabalho. Ao lado disto, é imperativa e urgente a mudança da cultura corporativista desse sistema, pela influência que exerce sobre o comportamento dos atores sociais". ${ }^{13}$

Altamiro Borges explica que o sindicalismo foi proibido durante a ditadura militar, já "o neoliberalismo procurou quebrar sua espinha dorsal; e as novas técnicas gerenciais tentam torná-lo supérfluo". Por isso, o avanço da organização sindical brasileira depende da atuação planejada em algumas matérias. Inicialmente, vislumbra-se a necessidade de politizar a classe, pois as disputas econômicas e corporativas de caráter imediatista não se mostram suficientes à aquisição prolongada de direitos, pois "sem um sindicalismo protagonista da luta política não haverá as urgentes mudanças estruturais". Em seguida, propugna-se a reorganização sindical de base nos ambientes laborais, o que é altamente combatido pelos empregadores. ${ }^{14}$

A terceira medida apontada refere-se à renovação da formação sindical, pois houve o envelhecimento das diretorias, em contraponto há o surgimento de novas relações de trabalho e o ingresso constante do jovem no mercado. Posteriormente, intenta-se a ação intersindical por meio da união da classe ante a fragmentação recorrente das entidades representativas de empregados. Por fim, almeja-se a ação de movimentos sociais em prol da inserção de outros entes (informais e desempregados, por exemplo) à contemporânea classe de trabalhadores caracterizada pela complexidade e pulverização. $^{15}$

Em decorrência da disseminação de regimes democráticos na América Latina, assim como da ratificação das Convenções 87 e 98 da OIT, tem ocorrido um processo de reformulação das legislações acerca da liberdade sindical. Porém, a temática possui queixas recorrentes perante o Comitê de Liberdade Sindical do citado órgão internacional. ${ }^{16}$

No magistério de Enoque Ribeiro dos Santos, há imperiosidade de uma reforma sindical convergente à eminência da revitalização do sindicalismo, assim

\footnotetext{
${ }^{13}$ TEIXEIRA, Gilnei M. Liberdade sindical no Brasil: uma visão estratégica. In: OIT. Reforma sindical e negociação coletiva. Brasília, DF: OIT, 2001. p. 55.

${ }^{14}$ BORGES, Altamiro. Encruzilhadas do sindicalismo. São Paulo: Anita Garibaldi, 2005. p. 42.

15 lbid., p. 43-44.

${ }^{16}$ VEGA RUIZ, María Luz. Reforma laboral en América Latina. Educación Obrera. Genebra, n.143/144, p.87-95, 2006. p. 92.
} 
como a valorização da negociação coletiva pelo Estado em um ambiente pluralista propício e sem o engessamento (regulamentação) da atuação sindical. ${ }^{17}$

O enfatizado desejo por uma reforma não pode ocasionar a propositura de equívocos, como a exacerbada crítica ao modelo vigente, tampouco a aclamação desmedida e impensada à ratificação da Convenção n. 87 da OIT, como especial antídoto aos problemas de ordem estrutural. Para tanto, Altamiro Borges recorda o entusiasmo do ex-presidente Lula com o pluralismo disposto no aludido diploma internacional, comparando a CLT (legislação sindical) a um "Al-5 dos trabalhadores". No entanto, deve-se cuidar para que o pluralismo não incuta na formação de "sindicatos-casa", isto é, à disposição dos interesses da classe empregadora. ${ }^{18}$

Evidentemente, o Brasil necessita olvidar muitas das características tradicionais que envolvem o sindicalismo hodierno, entretanto, o mero transporte de modelos prontos e implantados em outros países não representa a decisão mais prudente, conquanto sejam experiências de êxito invejável. Há que se priorizar a realidade nacional, almejando a reconstrução de organizações sindicais fortemente representativas e imbuídas de melhorar o sistema protetivo trabalhista.

\subsubsection{Proposta de Emenda Constitucional n. 369/05}

Em vista de ratificar o anseio por uma mudança no cenário sindical, está em tramitação no Congresso Nacional a Proposta de Emenda Constitucional (PEC) n. 369/05 e, em anexo, segue o Anteprojeto de Lei de Relações Sindicais com 238 artigos. Tais proposições surgiram em derivação às numerosas negociações entre diversos setores da sociedade, as quais, inicialmente, ocorreram em meados de 2003 durante o Fórum Nacional do Trabalho (FNT).

O citado espaço de diálogo de formação tripartite reuniu representantes dos trabalhadores, empregadores e do Governo; no que diz respeito às entidades

\footnotetext{
${ }^{17}$ SANTOS, Enoque Ribeiro dos. Reforma sindical e emenda constitucional n. 45/2004: fontes formais de sustentação do novo modelo sindical. In: SANTOS, Enoque Ribeiro dos; SILVA, Otávio Pinto e. (Coords.) Temas controvertidos do direito coletivo do trabalho no cenário nacional e internacional. São Paulo: LTr, 2006. p. 48-49.

${ }^{18}$ BORGES, Altamiro, op. cit., p. 83, 86, 162.
} 
sindicais, credenciaram-se apenas as instituições de caráter nacional. O FNT foi instituído pelo Governo Federal mediante o Decreto n. 4.796 de 30 de julho de 2003 e se incumbiu de atualizar e reformular a legislação sindical e trabalhista, assim como as organizações reguladoras do trabalho, adequando-as à efetividade econômica, política e social do país, conforme dispõe o seu Regimento Interno.

O texto da PEC e do anteprojeto desenhado pelas mencionadas classes surgiu a partir de perspectivas diametralmente opostas. Enquanto as centrais e o governo defenderam apenas a revisão inicial da estrutura coletiva, os empregadores (representantes) advogaram a favor da reforma trabalhista mediante a flexibilização de direitos, tal como pela redução do número de dirigentes estáveis e críticas à existência de entidades sindicais no local de trabalho. ${ }^{19}$

A PEC n. 369/2005 visa a alterar a redação dos artigos 8ำ 11, 37 e 114 da Constituição Federal de 1988. No que concerne ao art. 8ํㅗ se promulgada a proposta de emenda, passará a contar com nove incisos e um parágrafo único, os quais serão devidamente cotejados ao modelo vigente.

As modificações iniciam-se pelo caput com exaltação à liberdade sindical; apesar disso, o redator colocou a expressão "observando o seguinte". Tal frase transparece a ideia de restrição ou de contradição, pois afirma estabelecer um regime livre e simultaneamente emprega a ponderação. Em sentido oposto, ressalta-se a Constituição italiana, a qual se resume a dispor que a "organização sindical é livre", assim como o diploma constitucional português, o qual prescreve: "É reconhecida aos trabalhadores a liberdade sindical, condição e garantia da construção da sua unidade para defesa dos seus direitos e interesses" ${ }^{20}$

\footnotetext{
${ }^{19}$ BORGES, Altamiro, op. cit., p. 86-87.

${ }^{20}$ Nova redação com a reforma sindical: Art. $8^{\circ}$. É assegurada a liberdade sindical, observado 0 seguinte:

I - o Estado não poderá exigir autorização para fundação de entidade sindical, ressalvado o registro no órgão competente, vedadas ao Poder Público a interferência e a intervenção nas entidades sindicais; II - o Estado atribuirá personalidade sindical às entidades que, na forma da lei, atenderem a requisitos de representatividade, de participação democrática dos representados e de agregação que assegurem a compatibilidade de representação em todos os níveis e âmbitos da negociação coletiva; III - às entidades sindicais cabe a defesa dos direitos e interesses coletivos ou individuais do âmbito da representação, inclusive em questões judiciais e administrativas; IV - a lei estabelecerá o limite da contribuição em favor das entidades sindicais que será custeada por todos os abrangidos pela negociação coletiva, cabendo à assembléia geral fixar seu percentual, cujo desconto, em se tratando de
} 
Para José Pastore, ainda se opta pela proteção legal em detrimento da normatização coletiva entre as partes. Assim, "o sistema atual, altamente regulamentado por lei, dificilmente será abandonado. O mais provável é que ele venha a ser substituído por outro sistema igualmente regulado por lei". ${ }^{21} \mathrm{~A}$ regulamentação inflexível é salutar sob a ótica individual, pois é sabido que o trabalhador não possui condições equivalentes para se sobrepor à voracidade do capital; por outro lado, a norma jurídica voltada aos agrupamentos não deve possuir especificidades capazes de "engessar" as organizações sindicais.

No inciso I da nova redação do art. $8^{\circ}$, observa-se a substituição do verbete "lei" por "Estado", assim a proibição de se interferir na fundação de um organismo sindical não está restrita à legislação ordinária, mas a quaisquer atos concretos emanados do Poder Público com o objetivo de obstar. Também há a supressão do termo "sindicato" por "entidade sindical"; nesse caso, pretende-se ampliar a circunscrição sindical, pois no texto hoje em vigor, subentende-se tratar apenas do ente de base, ainda que na prática refira-se às organizações de nível superior.

Quanto ao inciso II, nota-se a extinção da unicidade sindical. Atualmente, o monopólio de representação tem causado o "desencanto dos trabalhadores", uma vez que os atores sociais, de modo geral, não estão conectados ao movimento sindical. Por isso, a mudança normativa decorrente da reforma sindical demanda o estabelecimento cultural de um relacionamento efetivo do empregado com a respectiva organização representativa, isto é, visando a emendar as deficiências de representação. Desse modo, evitar-se-á, por exemplo, o saneamento tardio de vícios contratuais pela Justiça do Trabalho

entidade sindical de trabalhadores, será efetivado em folha de pagamento; $\mathbf{V}$ - a contribuição associativa dos filiados à entidade sindical será descontada em folha de pagamento; VI - ninguém será obrigado a filiar-se ou a manter-se filiado a sindicato; VII - é obrigatória a participação das entidades sindicais na negociação coletiva; VIII - o aposentado filiado tem direito a votar e ser votado nas organizações sindicais; e IX - é vedada a dispensa do empregado sindicalizado a partir do registro da candidatura a cargo de direção ou representação sindical e, se eleito, ainda que suplente, até um ano após o final do mandato, salvo se cometer falta grave nos termos da lei. Parágrafo único. As disposições deste artigo aplicam-se à organização de entidades sindicais rurais e de colônias de pescadores, atendidas as condições que a lei estabelecer.

${ }^{21}$ PASTORE, José, op. cit., p. 54. 
somente ao fim do vínculo empregatício ou a criação de um modelo pluralista repleto de novas entidades sem legitimidade. ${ }^{22}$

O aludido dispositivo também estabelece a atribuição de personalidade sindical às entidades que atendam aos requisitos de representatividade.

Concernente ao inciso III, o novo texto altera "sindicato" para "entidades sindicais". Ademais, reforça "a defesa dos direitos e interesses coletivos ou individuais", bem como a atuação em matérias judiciais e administrativas para todo o âmbito da representação e exclui o enquadramento por categorias.

A composição dos sindicatos não deve emanar do imperativo estatal; desse modo, não cumpre ao Estado a aferição de critérios de associação, como sucede atualmente com a formação de categorias. Otávio Pinto e Silva explica que não há impedimentos para a continuidade de agrupamento consoante condições símiles de vida ou das atividades laborais desenvolvidas, desde que essa decisão advenha do entendimento da classe de trabalhadores. No tocante aos empregadores, assevera a mesma liberdade de composição, mas decorrente da reciprocidade de interesses econômicos. ${ }^{23}$

No item IV, há a modificação do sistema de custeio das entidades sindicais, a qual exclui a contribuição sindical obrigatória e, consequentemente outras cobranças sindicais. Em substituição a essas receitas, implanta-se a contribuição negocial, financiada por todos os beneficiados da negociação coletiva (independente de filiação). Prevê também a contribuição associativa, destinada apenas aos associados, cujo desconto ocorrerá em folha de pagamento, de acordo com o inciso $\mathrm{V}$.

Em relação ao inciso $\mathrm{VI}$, (atual inciso $\mathrm{V}$ ) não há modificações, preceitua a liberdade sindical individual positiva e negativa, isto é, o direito de filiação e desfiliação. No tocante ao item VII (hoje, inciso VI), mantém a obrigatoriedade da participação das "entidades sindicais" e não apenas "sindicatos" às negociações coletivas.

\footnotetext{
${ }^{22}$ HINZ, Henrique Macedo. Mais um olhar sobre a reforma sindical. LTR: Legislação do Trabalho. Suplemento Trabalhista, São Paulo, v.42, n.39, p.177-81, 2006. p. 180-181.

${ }^{23}$ SILVA, Otávio Pinto e. O Brasil precisa de uma reforma sindical? In: SANTOS, Enoque Ribeiro dos; SILVA, Otávio Pinto e. (Coords). Temas controvertidos do direito coletivo do trabalho no cenário nacional e internacional, São Paulo: LTr, 2006. p. 11.
} 
O aposentado filiado permanece com o direito de sufrágio nas organizações sindicais, garantia prevista no novo inciso VIII (atualmente, item VII). Por fim, o inciso IX (no presente, inciso VIII) e o parágrafo único permanecem com idêntica semântica, exceto pela substituição da expressão "sindicatos" por "entidades sindicais", garantindo a estabilidade sindical aos ocupantes de cargo de direção ou representação e a reciprocidade de aplicação dos dispositivos às organizações rurais e colônias de pescadores, respectivamente.

A PEC n. 369/05, se aprovada, revogará o art. 11 que cuida da eleição de um representante nas empresas com mais de duzentos empregados e estabelecerá a representação dos trabalhadores no local de trabalho. No que diz respeito ao art. 37 , a reforma visa à supressão da "negociação coletiva" prevista no inciso VII, mantendo somente o direito de greve ao serviço público.

A proposta é encerrada com a modificação de alguns dispositivos do art. 114 da Carta Magna no que tange à competência da Justiça do Trabalho para julgar e processar, especialmente acerca do ajuizamento do dissídio coletivo, diminuindo-Ihe sua aplicabilidade e nomenclatura. ${ }^{24}$ No que diz respeito ao Anteprojeto de Relações Sindicais, analisaram-se suas principais contribuições ao sindicalismo brasileiro, como a estrutura sindical e seus principais elementos, as novas fontes de custeio das entidades sindicais, assim como a representação dos trabalhadores no local de trabalho.

\subsection{Especificidades da estrutura sindical no projeto de reforma sindical}

De acordo com Anteprojeto de Lei de Relações Sindicais, a formação inicial das entidades dependerá da aquisição de personalidade sindical para o

\footnotetext{
${ }^{24}$ Art. 114. [...]

III - as ações sobre representação sindical, entre entidades sindicais, entre entidades sindicais e trabalhadores, e entre entidades sindicais e empregadores; [...] $\S 2{ }^{\circ}$ Recusando-se qualquer das partes à arbitragem voluntária, faculta-se a elas, de comum acordo, na forma da lei, ajuizar ação normativa, podendo a Justiça do Trabalho decidir o conflito, respeitadas as disposições mínimas legais de proteção ao trabalho, bem como as convencionadas anteriormente. $\S 3^{\circ} \mathrm{Em}$ caso de greve em atividade essencial, o Ministério Público do Trabalho tem legitimidade para ajuizamento de ação coletiva quando não forem assegurados os serviços mínimos à comunidade ou assim exigir o interesse público ou a defesa da ordem jurídica.
} 
exercício das suas prerrogativas. ${ }^{25}$ Para tanto, será necessário o registro dos respectivos atos constitutivos e dos estatutos da organização junto ao Registro Civil de Pessoas Jurídicas, bem como o reconhecimento de representatividade.

A representatividade será comprovada ou derivada. Na primeira, a organização sindical deverá atender critérios objetivos, os quais serão obtidos por meio da taxa de sindicalização, distribuição territorial e a presença no setor $^{26}$ ou ramo de atividade econômica. Já a representatividade derivada, decorrerá da transferência de representação devidamente comprovada das centrais, federações ou confederações aos sindicatos de base. Assim, preenchidos os requisitos, a personalidade sindical será conferida pelo Ministro do Trabalho e Emprego.

A análise da "representatividade derivada" permite supor que se trata de um método artificial de transferência de representatividade, pois a verdadeira filiação ocorre em relação à entidade de cúpula. Mas, o Ministério do Trabalho e Emprego contestou tal entendimento, segundo cartilha ${ }^{27}$ elaborada pelo órgão do Poder Executivo, o processo derivado é utilizado em outros ordenamentos, cujas organizações superiores definem sua base e estrutura de acordo com o ramo ou setor de atividade econômica, possibilitando a estruturação conforme julguem mais satisfatório.

Por consequência, o projeto estabelece a representação das organizações sindicais dos trabalhadores em âmbito nacional, interestadual, estadual, intermunicipal e municipal por meio das centrais sindicais,

${ }^{25}$ O Anteprojeto de Lei de Relações Sindicais lista as seguintes prerrogativas aos entes sindicais: I

- representar os interesses do respectivo âmbito de representação perante as autoridades administrativas e judiciárias; II - propor e participar de negociação coletiva; III - celebrar contratos coletivos de trabalho; IV - atuar em juízo como legitimado ordinário ou extraordinário; V estabelecer contribuições de negociação coletiva.

${ }^{26}$ Os setores econômicos e os ramos de atividade são os critérios de agregação que substituem o sistema atual de categorias. Eles serão determinados por ato do Ministro do Trabalho e Emprego por meio de proposta do Conselho Nacional de Relações de Trabalho (CNRT). Tal órgão de formação tripartite constitui-se de uma Câmara Tripartite e duas Câmaras Bipartites, imbuídas, por exemplo: na determinação dos mencionados setores e ramos, assim como na aprovação do procedimento de recolhimento e da prestação de contas dos valores da contribuição de negociação coletiva.

${ }^{27}$ FÓRUM NACIONAL DO TRABALHO. Espaço de diálogo e negociação. Reforma sindical: perguntas e respostas. 2.ed. rev. e atual. Brasília: Ministério do trabalho e emprego, 2005. Questão n. 52. p. 21. 
confederações, federações e sindicatos, desde que atendidos os requisitos impostos legalmente para o reconhecimento da representatividade. ${ }^{28}$

A central sindical será formada em âmbito nacional a partir de sindicatos pertencentes a qualquer setor econômico ou ramo de atividade, podendo criar confederação, federação e sindicato. Por outro lado, a confederação não filiada a nenhuma central sindical, constituir-se-á em amplitude nacional a partir de sindicatos pertencentes à idêntica área econômica, inclusive admitindo a constituição de outras entidades de grau inferior; o mesmo se dará com a federação não atrelada à central, observada a abrangência estadual e o ramo de atividade. Já os sindicatos seguirão o ramo de atividade predominante das empresas em área não inferior a um município.

Desse modo, a reforma impulsiona à centralização do sindicalismo nos órgãos de cúpula, no caso da classe trabalhadora serão as centrais sindicais, inclusive, porque muitos sindicatos de base sobreviverão de forma exclusiva em razão da "representatividade derivada". A centralidade pode ser analisada positivamente quando se observa a expressividade das centrais em

\footnotetext{
${ }^{28}$ As centrais sindicais obedecerão a três requisitos, quais sejam: I - filiação de sindicatos com representatividade comprovada em pelo menos 18 (dezoito) unidades da Federação, distribuídas nas 5 (cinco) regiões do país; II - filiação de sindicatos com representatividade comprovada em pelo menos 9 (nove) unidades da Federação, com índice de filiação igual ou superior a 15\% (quinze por cento) do total de trabalhadores em cada uma delas; III - filiação de trabalhadores aos sindicatos filiados à central sindical em número igual ou superior a $22 \%$ (vinte e dois por cento) do total de trabalhadores nos respectivos âmbitos de representação; IV - filiação de trabalhadores aos sindicatos filiados à central sindical, em pelo menos 7 (sete) setores econômicos, em número igual ou superior a 15\% (quinze por cento) do total de trabalhadores em cada um desses setores em âmbito nacional. Já as confederações atenderão aos seguintes critérios: I - filiação de sindicatos com representatividade comprovada em pelo menos 18 (dezoito) unidades da Federação, distribuídas nas 5 (cinco) regiões do país; II - filiação de sindicatos com representatividade comprovada em pelo menos 9 (nove) unidades da Federação, com índice de filiação igual ou superior a 15\% (quinze por cento) do total de trabalhadores no respectivo âmbito de representação em cada uma dessas unidades federativas; III - filiação de trabalhadores aos sindicatos filiados à confederação em número igual ou superior a $22 \%$ (vinte e dois por cento) do total de trabalhadores nos respectivos âmbitos de representação. Enquanto as federações observarão as condições de: I - filiação de trabalhadores aos sindicatos filiados à federação em número igual ou superior a $22 \%$ (vinte e dois por cento) do total de trabalhadores nos respectivos âmbitos de representação desses sindicatos; II - filiação de trabalhadores aos sindicatos filiados à federação em número igual ou superior a 15\% (quinze por cento) do total de trabalhadores no âmbito de representação da federação. Por fim, os sindicatos obterão representatividade mediante vinculação a central sindical, ou a confederação, ou a federação ou mediante a filiação de número igual ou superior a $20 \%$ (vinte por cento) dos trabalhadores do âmbito de representação.
} 
relação à politização das reivindicações; de outro modo, negativamente, quando incorrer no risco de ensejar o "peleguismo de cúpula". ${ }^{29}$

As transformações no âmbito sindical não devem dizimar a atuação dos sindicatos em prol à valorização das centrais sindicais, estas devem coexistir com as confederações em nível superior. Todavia, há que se delimitar o plano de ação de cada uma das mencionadas instituições, isto é, a confederação atrelada à categoria, enquanto a central ao caráter de "supra categorias" e de dar suporte aos entes débeis, sem olvidar a imprescindibilidade do sindicato às reais necessidades dos trabalhadores. ${ }^{30}$

Referente à constituição das entidades sindicais patronais, segundo 0 Anteprojeto, possuirão o mesmo âmbito de atuação das organizações defensoras da classe trabalhadora, exceto pelo diferencial de não contemplarem a central sindical de empregadores. A cúpula confederativa será formada pelas federações estaduais/interestaduais e pelos sindicatos do mesmo setor econômico.

A federação não vinculada ao sistema confederativo, formar-se-á por meio da filiação ou correlação de sindicatos do mesmo ramo ou setor econômico, e ainda, podendo formar sindicatos junto a sua estrutura. Tal independência também será conferida aos sindicatos; dessa forma, eles obedecerão ao critério do setor econômico ou ramo de atividade preponderante das empresas, respeitado o território mínimo de um município. Além disso, as entidades sindicais de empregadores obrigar-se-ão a respeitar os critérios $^{31}$ específicos de representatividade.

\footnotetext{
${ }^{29}$ VIANA, Márcio Túlio (2004), op. cit., p. 66.

${ }^{30}$ NASCIMENTO, Amauri Mascaro (2007), op. cit., p. 652-653.

${ }^{31}$ As confederações deverão obedecer aos seguintes requisitos: Art. 20 [...] । - filiação de sindicatos, com representatividade comprovada, em pelo menos 18 (dezoito) unidades da Federação, distribuídas nas 5 (cinco) regiões do país; II - filiação de sindicatos, com representatividade comprovada, em pelo menos 12 (doze) unidades da Federação, com índice de filiação igual ou superior a $20 \%$ (vinte por cento) da soma das empresas ou unidades econômicas correspondentes aos âmbitos de representação desses sindicatos; III - filiação de sindicatos, com representatividade comprovada, em pelo menos 18 (dezoito) unidades da Federação, nas quais a soma do capital social das empresas ou unidades econômicas filiadas aos sindicatos vinculados à confederação seja igual ou superior a $20 \%$ (vinte por cento) da soma do capital social das empresas ou unidades econômicas correspondentes aos âmbitos de representação desses sindicatos; IV - filiação de sindicatos, com representatividade comprovada, em pelo menos 18 (dezoito) unidades da Federação, nas quais a soma do número de empregados nas empresas ou unidades econômicas filiadas aos sindicatos vinculados à confederação seja igual ou superior a $20 \%$ (vinte por cento) da soma dos empregados as empresas ou unidades econômicas correspondentes aos âmbitos de representação desses sindicatos. Quanto às federações, deverão observar: Art. 21 [...] I - filiação de sindicatos com
} 
Ante as ponderações efetuadas, constata-se que não há a predominância total da unicidade sindical visando a tolher a pluralidade da criação de organizações, independente do grau de representação e em qualquer unidade territorial, a qual se configura pela área de um município. Apesar do Anteprojeto de Lei trazer inovações, ainda carrega muitos vestígios conservadores.

A alteração repentina para o regime pluralista acarretaria a fragmentação do sistema e, por consequência, o enfraquecimento das organizações e a flexibilização de direitos. Por isso, propugna-se pela transformação paulatina, cujo início se dê no fortalecimento da base e na extensão da representação nos locais de trabalho. ${ }^{32}$

Visando a atenuar os efeitos do novo modelo às organizações sindicais atuais, o projeto de lei estabelece no art. 38, a denominada "exclusividade de representação", que se fundamenta na "concessão de personalidade sindical a um único sindicato no respectivo âmbito de representação". Trata-se da possibilidade de manutenção do monopólio sindical à entidade que já o possuía anteriormente à entrada em vigor da Lei.

Para tanto, a organização deverá atentar para certos requisitos, por exemplo: prazo para opção do regime de exclusividade, deliberação da assembleia de filiados e não-filiados, comprovação da representatividade durante o período de transição e aderir às normas estatutárias definidas pelo CNRT. Adquirida a exclusividade, a existência de novas instituições no mesmo âmbito de representação estará condicionada ao desmembramento da base.

\footnotetext{
representatividade comprovada, em pelo menos 3 (três) ramos de atividade econômica; II filiação de sindicatos com representatividade comprovada e cuja soma de empresas ou unidades econômicas filiadas seja igual ou superior a $20 \%$ (vinte por cento) da soma das empresas ou unidades econômicas nos respectivos âmbitos de representação; III - filiação de sindicatos com representatividade comprovada e cuja soma de capital social das empresas ou unidades econômicas filiadas seja igual ou superior a $20 \%$ (vinte por cento) da soma do capital social das empresas ou unidades econômicas nos respectivos âmbitos de representação; IV - filiação de sindicatos com representatividade comprovada e cuja soma do número de empregados nas empresas ou unidades econômicas filiadas seja igual ou superior a $20 \%$ (vinte por cento) da soma do número de empregados das empresas ou unidades econômicas nos respectivos âmbitos de representação. Já os sindicatos: Art. 22 [...] I - filiação de número igual ou superior a $20 \%$ (vinte por cento) das empresas ou unidades econômicas em seu âmbito de representação; II - filiação de empresas ou unidades econômicas, cuja soma de capital social seja igual ou superior a $20 \%$ (vinte por cento) da soma do capital social das empresas ou unidades econômicas no respectivo âmbito de representação; III - filiação de empresas ou unidades econômicas, cuja soma do número de seus empregados seja igual ou superior a $20 \%$ (vinte por cento) da soma do número de empregados das empresas ou unidades econômicas no respectivo âmbito de representação.

${ }^{32}$ PASSOS, Edésio, op. cit., p. 533.
} 
Dessa forma, verifica-se que a "exclusividade de representação" mantém resquícios da unicidade sindical, pois é pouco provável que as organizações não optem pela manutenção do monopólio de representação, ainda que tenham de comprovar sua representatividade. Nessa perspectiva, a cartilha $^{33}$ do Ministério do Trabalho e Emprego, conquanto indiretamente, admite a dubiedade presente no projeto: "o novo modelo conjuga princípios que derivam da unicidade, como a exclusividade de representação, com princípios da liberdade sindical, como a possibilidade de existência de mais de uma entidade sindical em um mesmo âmbito de representação".

A implantação de um sistema pluralista na base sindical atingirá diretamente os empregadores e trabalhadores. Por isso, é imperioso verificar as perspectivas desses atores sociais quanto à aceitação ou negação ao aludido modelo organizatório. A classe patronal é favorável ao pluralismo, ambicionando níveis mais elevados de fragmentação dos trabalhadores, já assolados por inúmeros fatores que tornam a atividade laboral precária. Por outro lado, a classe de trabalhadores visualiza maior "agilidade" aos sindicatos, principalmente devido à possibilidade de agregar os trabalhadores excluídos do dia a dia sindical. ${ }^{34}$

Por sua vez, há trabalhadores contrários a existência desmedida de entidades na base, pois causaria maior pulverização da categoria e poderia incitar a fundação de sindicatos imbuídos aos interesses dos empresários. Já o setor empresarial defensor da unicidade aspira à manutenção dos laços entre si. ${ }^{35}$

Evidentemente, o remodelamento sindical deve ocorrer de maneira comedida, desassociado de fórmulas exatas importadas. Para tanto, incumbe-se a participação de todos os entes interessados na construção dessa estrutura e não exclusivamente àqueles detentores de maior e significativa representatividade. ${ }^{36}$

\footnotetext{
${ }^{33}$ FNT..., op. cit., p. 18.

${ }^{34}$ VIANA, Márcio Túlio. A reforma..., op. cit., p. 1422.

${ }^{35}$ Ibid.

${ }^{36}$ NASCIMENTO, Amauri Mascaro. Problemas..., op. cit., p. 653.
} 
3.2.1 Extinção das fontes de sustentação econômica dos sindicatos

Segundo Antônio Moreira de Carvalho Neto, o fim da contribuição sindical obrigatória e a ratificação da Convenção n. 87 da OIT poderia ocasionar o surgimento de duas conjunturas. Primeiramente, se a extinção da cobrança ocorresse de maneira repentina, consequentemente poderia ensejar o fim de inúmeras organizações sindicais em todos os graus de representação e muitos entes de representatividade nula desapareciam. Por outro lado, em seguida, haveria um "boom" descontrolado de novas entidades em disputa pela divisão da base territorial. ${ }^{37}$

No segundo cenário, se a contribuição não fosse dizimada imediatamente e a Convenção n. 87 aplicada posteriormente, possibilitaria a existência de um lapso temporal para a transição de sistemas. Por isso, propugna-se um prazo razoável, por exemplo, correspondente a um mandato sindical (três anos), pois facilitaria a preparação da comunidade às mudanças vindouras. $^{38}$

A PEC n. 369/05 visa a extinguir o sistema de contribuição sindical hodierno e implantar novas fontes de sustentação econômica das entidades sindicais, quais sejam a contribuição associativa e a contribuição de negociação coletiva. O Anteprojeto de Lei de Relações Sindicais pormenoriza que as receitas das organizações serão auferidas mediante as ditas prestações, assim como pelos frutos dos rendimentos do seu patrimônio, doações e multas. Assim, serão revogadas a contribuição sindical compulsória, a contribuição confederativa, a contribuição assistencial e a mensalidade sindical.

Conforme dispõe o Anteprojeto de Lei, a contribuição sindical obrigatória não será extinta de forma automática com a sua aprovação, a supressão ocorrerá de forma gradativa com relação aos descontos dos trabalhadores e empregadores. Para a classe de trabalhadores a aduzida cobrança findar-se-á em três anos a partir do início da lei, correspondente a:

${ }^{37}$ CARVALHO NETO, Antônio Moreira de. Liberdade e autonomia sindical no Brasil: meio século de atraso na aplicação da convenção no 87 da OIT. In: PEREIRA, Armand F. (Org.). Reforma sindical e negociação coletiva. Brasília: OIT, 2001. p. 74-75.

${ }^{38}$ Ibid., p. 74-75. 
$75 \%$ de um dia no primeiro ano, $55 \%$ de um dia de trabalho no segundo ano e $35 \%$ de um dia de trabalho no terceiro ano. Além disso, durante o período transitório, o rateio entre as entidades sindicais será na proporção de: $5 \%$ para a confederação, $15 \%$ para a federação, $60 \%$ para o sindicato e $20 \%$ para a "Conta Especial Emprego e Salário".

Quanto à contribuição sindical dos empregadores será abolida no interstício de cinco anos, sendo que no biênio inicial permanecerá a cobrança nos moldes atuais, decaindo somente a partir do terceiro ano na proporção de: $75 \%$ no terceiro ano, $55 \%$ no quarto ano e $35 \%$ no quinto ano. Já o repasse às entidades superiores será de: $5 \%$ para as confederações, 15\% para as federações, 60\% para os sindicatos e $20 \%$ para a "Conta Especial Emprego e Salário".

Evidentemente, o citado período de transição é salutar à adaptação das novas realidades pelas organizações sindicais e, especialmente ao trabalhador que possuirá nova sistemática para o pagamento da sua contribuição.

No que tange à contribuição associativa, será custeada somente pelos membros filiados à entidade sindical conforme o estatuto e as deliberações em assembleia. Ademais, poderá ser cobrada por intermédio de desconto em folha de pagamento, desde que autorizada pelo associado e requerida à empresa pela entidade sindical dos trabalhadores.

Quanto à contribuição de negociação coletiva ou negocial, para custear a participação sindical na pactuação ou no efeito geral do resultado. A proposta do valor a ser cobrado será apreciada e deliberada anualmente em assembleia pelos destinatários da negociação (filiados ou não) e não admitirá oposição. Em relação ao desconto, será justificado pela produção de convenção ou acordo coletivo de trabalho, bem como pela certificação de ter sido frustrada.

Almir Pazzianotto Pinto entende ser arbitrária a impossibilidade de contestar o valor da contribuição aprovado em assembleia disposto no projeto de lei, pois "atropela todas as garantias constitucionais de livre associação [...] Em outras palavras, o cidadão trabalhador ficaria privado do direito de resistir à 
decisão de assembléia de que não participou, da qual discorda e que o prejudica". 39

No art. 46 do projeto, há a advertência para a imprescindibilidade de constar no contrato negociado as entidades para as quais o repasse deverá ser efetuado, tendo em vista a participação na pactuação. Destarte, será possível o rateio equivalente ao índice de sindicalização e da posição na estrutura organizativa, na proporção de: $10 \%$ para a central sindical, 5\% para a confederação, $10 \%$ para a federação, $70 \%$ para o sindicato e $5 \%$ para o Fundo Solidário de Promoção Sindical (FSPS).

Desse modo, as centrais sindicais disporão de receita própria independente da aquiescência dos sindicatos. Argúi-se na doutrina, a hipótese de outra forma de compartilhamento de receitas, advinda, por exemplo, da transferência total das receitas às entidades de base e, posteriormente, uma negociação com as entidades de nível superior acerca da divisão; desse modo, afiançaria maior controle aos sindicatos. Mas, na conjuntura apresentada pelo projeto confia-se "poder econômico, organizacional e político às Centrais Sindicais. Transfere também poder de barganha". 40

Por outro lado, a destinação absoluta da arrecadação aos sindicatos poderia ocasionar conflitos intransponíveis pela negociação entre as partes, já que envolveria a subjetividade de cada entidade acerca da aplicação das verbas, podendo resultar em litígios judiciais procrastinados.

No que concerne ao valor de cobrança da contribuição negocial dos trabalhadores, além de observar a definição em assembleia, não poderá ultrapassar o montante de $1 \%$ sobre o total da remuneração líquida percebida pelo trabalhador no ano anterior, podendo ser dividido, no mínimo, em três parcelas a serem pagas a partir do mês de abril. $O$ trabalhador que romper 0 vínculo empregatício antes do pagamento terá descontada, proporcionalmente, a importância no momento do recebimento das verbas rescisórias.

\footnotetext{
${ }^{39}$ PINTO, Almir Pazzianotto. A contra-reforma sindical. Síntese Trabalhista, Porto Alegre, v.16, n.191, p.5-7, maio. 2005. p. 6.

${ }^{40}$ ZYLBERSTAJN, Hélio. A reforma sindical de Lula. Revista de Direito do Trabalho, São Paulo, v.31, n.119, p.94-116, jul./set. 2005. p. 109.
} 
O sistema vigente prevê no art. 580 da CLT, a autorização para a exigência única da contribuição sindical compulsória no valor de um dia de trabalho sobre a remuneração mensal do trabalhador. Nesse contexto, um empregado que possua a remuneração de $R \$ 2.000,00$ por mês, recolherá aproximadamente $R \$ 66,00$. Por outro lado, de acordo com o Anteprojeto de Lei desembolsará $R \$ 240,00$, uma vez que o cálculo será projetado sobre a remuneração anual. Assim, o modelo de cobrança em tramitação no Congresso mostra-se desvantajoso e prejudicial ao trabalhador, já que o onera ainda mais.

Nessa perspectiva, José Alberto Couto Maciel insurge-se acerca da contribuição de negociação coletiva. Assim sendo, é mister analisar a ponderação:

\begin{abstract}
Assim, todo o empregado, sindicalizado ou não, será obrigado a pagar a contribuição de negociação, não podendo a ela se opor, o que contraria flagrantemente o princípio da liberdade sindical [...] Mas qual - calor dessa contribuição? Aqui está a grande farsa. $O$ valor obrigatório deverá ser muito superior ao pago atualmente [...] É um absurdo, é gritantemente assustador a fome de dinheiro e o ataque ao trabalhador feito por esta proposta de alteração constitucional, e é este o anteprojeto de lei de relações sindicais elaborado para "modernizar as relações sindicais" ${ }^{41}$
\end{abstract}

De acordo com Amauri Mascaro Nascimento, para o trabalhador é indiferente a quantidade de contribuições a se pagar, o que se torna indispensável é o montante a ser cobrado. Ademais, em decorrência de a contribuição ser devida pela negociação coletiva, ainda que não se tenha firmado o contrato coletivo, incorre-se na possibilidade de entidades sindicais mal intencionadas almejarem celebrações duvidosas simplesmente com o intuito de arrecadação. ${ }^{42}$

Com relação à contribuição negocial dos empregadores, deverá ser recolhida todo mês de maio de cada ano por todas as empresas, independente do tamanho. A cobrança limita-se a $0,8 \%$ sobre o capital social do empreendimento, tratando-se do setor rural sobre o valor da terra nua tributável,

\footnotetext{
${ }^{41} \mathrm{MACIEL}$, José Alberto Couto. Contribuição de negociação coletiva: lesão aos trabalhadores na reforma sindical. LTr: Legislação do Trabalho. Suplemento Trabalhista, São Paulo, v.41, n.44, p.175-7, 2005. p. 176.

${ }^{42}$ NASCIMENTO, Amauri Mascaro. Compêndio de direito sindical. 7.ed. São Paulo: LTr, 2012. p. 651 e 653.
} 
observada a importância mínima de $\mathrm{R} \$ 100,00$ e máxima de até oitocentas vezes sobre o mínimo. No rateio, visto que não há central sindical de empregador, a receita será dividida em: 10\% para a confederação, 20\% para a federação, $65 \%$ para o sindicato e $5 \%$ para o FSPS.

Afastada a polêmica envolvendo a cobrança da contribuição de negociação coletiva, o Anteprojeto de Relações Sindicais inovou ao introduzir a subseção "prestação de contas" pelas entidades sindicais, que deverão apresentar lançamentos contábeis que oportunizem a quaisquer representados 0 acompanhamento das transações, débitos e créditos, recolhimento e repasse das contribuições e a composição patrimonial. Torna-se dever dos dirigentes, sob pena de violação: a regular escrituração contábil e prestação anual de contas, disponibilização por 5 anos dos balanços e outros documentos que comprovem os lançamentos, bem como proporcionar o acesso desses dados a qualquer representado.

Esse mecanismo de apresentação da arrecadação e gastos das organizações sindicais não viola a proibição de interferência e intervenção nas entidades sindicais, ao contrário, mostra-se como eficaz instrumento de fiscalização para que os representados visualizem a real destinação das suas contribuições e impeça o enriquecimento ilícito de certos administradores.

3.2.2 Representação dos trabalhadores no local de trabalho

Parte dos trabalhadores, no Brasil contemporâneo, clama pela existência do sindicato de empresa, sustentam que tal forma de representação estaria mais próxima à realidade e necessidades dos trabalhadores. Entretanto, tal modelo representativo encontra óbices na legislação em vigor e até mesmo com a aprovação do Anteprojeto de Lei em comento, conforme as observações a seguir.

De acordo com a Organização Internacional do Trabalho, a "participação dos trabalhadores nas decisões da empresa" possui objetivos que 
estão interligados entre si, os quais se dividem em três grandes categorias sob os seguintes pontos de vista: ético, político-social e econômico. ${ }^{43}$

Sob o ângulo ético, a participação do trabalhador propende-se ao desenvolvimento da personalidade humana ou da realização do indivíduo, baseada na solidificação do homem e da dignidade humana prevista na Declaração Universal dos Direitos Humanos. Nesse ínterim, o conceito ético atribuído a todo trabalhador em sua qualidade humana expressou-se em contextos diversificados, desde encíclicas papais a constituições nacionais e movimentos sindicais. ${ }^{44}$

No que diz respeito aos objetivos de ordem político-social, apresentamse de forma heterogênea e formam a chamada "democracia industrial" ou as seguintes expressões: "democracia laboral", "democracia no trabalho", "democracia na vida profissional" ou "democracia na empresa". Nota-se a existência de um paradoxo, pois a vivência do trabalhador na área política dá-se como a de qualquer outro cidadão, especialmente em períodos eleitorais quando sua escolha (voto) é eminente, todavia, não tem voz na tomada de decisões no local de trabalho que lhe repercutem diretamente. "No se puede considerar a um hombre maduro como ciudadano para la democracia política y al miesmo tiempo negarle como trabajador el derecho a la deocracia em la vida económica."45

Faz-se imperativo retificar tais contradições por meio da implementação da participação dos trabalhadores nas decisões da empresa e fortalecer a democracia política, colocando em prática seus princípios na vida econômica. Assim, a democratização da empresa externa-se sob diferenciadas configurações, desde que se reconheça o direito dos trabalhadores e de seus representantes negociarem as condições de trabalho no âmbito da empresa, protegendo seus interesses contra decisões superiores que possam causar prejuízos. ${ }^{46}$

Quanto aos objetivos de ordem econômica, ressoam direta ou indiretamente na melhoria da eficiência da empresa. Com o auxílio do trabalhador favorece-se, por exemplo: o melhoramento quantitativo e qualitativo da produção; a

\footnotetext{
${ }^{43}$ OIT. Oficina Internacional del Trabajo. Participación de los trabajadores em las decisiones de la empresa. Ginebra, 1981. p. 9.

${ }^{44}$ Ibid., p. 10.

45 lbid., p. 11.

46 Ibid., p. 11-12
} 
utilização racional da mão de obra e de matéria-prima; a introdução de técnicas novas. A participação pode resultar na diminuição das zonas de conflitos de interesses entre a direção e os empregados, o que, consequentemente, aprimora as relações laborais. Por isso, o Poder Público visualiza a participação no local de trabalho como meio de aumentar a eficiência empresarial e prevenir conflitos. ${ }^{47}$

Sendo assim, a participação fundada nos interesses comuns dos trabalhadores e empregadores reproduz o bom funcionamento da empresa e proporciona rentabilidade. Por conseguinte, garante inúmeros benefícios, como a preservação de empregos e a criação de postos, bem como o melhoramento do trabalho e da remuneração. ${ }^{48}$

A introdução da organização sindical no ambiente laboral oportunizará a participação efetiva dos trabalhadores no processo de negociação, isto é, ingressar de forma concreta no cotidiano sindical, inclusive com efeitos atenuantes ao poder disciplinar e de direção do empregador, sem a existência de represálias e possibilita a defesa de direitos fundamentais como dignidade humana. Ademais, à dita representação local caberá a mediação de conflitos individuais de trabalho, o que não poderá ensejar a facilitação para se usurpar direitos. ${ }^{49}$

Evidentemente, o empregador tem à disposição o poder de direção, principalmente porque é o detentor dos meios de produção. Tal poderio se realiza por meio do poder de organização, do poder de regulamentação, do poder de fiscalização e do poder disciplinar, os quais devem ter sua aplicação relativizada. De fato, a classe empresarial possui liberdade para dispor do modo de operação do seu empreendimento, mas até o limite que não prejudique terceiros (trabalhadores e a sociedade). Por isso, a terminologia "poder" deve ser interpretada como um direito, o qual não pode ensejar abuso de direito.

Nesse contexto, o trabalhador deve ser considerado um colaborador (sentido literal do vocábulo) no ambiente empresarial, e não apenas uma expressão falaciosa com o intuito de enaltecer a empresa perante a clientela. Assim, o

\footnotetext{
${ }^{47}$ OIT (1981), op. cit., p. 18.

${ }^{48}$ Ibid., p. 20.

${ }^{49}$ SILVA, Sayonara Grillo Coutinho Leonardo. Relações coletivas de trabalho entre a mudança e a conservação: perscrutando o projeto de emenda constitucional 369 e o anteprojeto de lei da reforma sindical. Revista de Direito do Trabalho. São Paulo, v.31, n.119, p.185-204, jul./set. 2005. p. 197.
} 
empregado deve participar do processo de gestão que o envolva direta ou indiretamente.

Consoante 0 entendimento internacional, a instituição das representações nos locais de trabalho ocorrem de forma voluntária, legal ou por intermédio de acordos nacionais. Quanto às instituições voluntárias, são aquelas estabelecidas pela vontade do empregador ou por meio de negociação coletiva sindical, não há a participação do legislador na aferição do instituto. Citam-se como exemplo os Estados Unidos da América, cujas pactuações entre empregados e empregadores no ambiente laboral são habituais. ${ }^{50}$

Em relação aos organismos decorrentes da lei, ressalta-se sua difusão e reconhecimento, uma vez que se articula com a estrutura sindical e, simultaneamente conserva sua identidade própria, seja no interior ou no exterior da empresa. Registra-se as primeiras legislações acerca dos conselhos de empresa entre 1918 e 1920 na Alemanha, Áustria, antiga Tchecoslováquia e Noruega e, após a Segunda Guerra Mundial, expandiram-se para a Europa ocidental e central. ${ }^{51}$ Hoje, sublinha-se a normatização alemã, a qual prevê entre outros pontos: os espaços de eleição do conselho, as formas de eleger um conselho, a estrutura jurídica da representação na empresa e os direitos do conselho, tal como as violações dos direitos de participação causadas pelos empregadores. ${ }^{52}$

No que se refere às instituições oriundas de acordos nacionais, José Francisco Siqueira Neto as explica mediante a apresentação de alguns sistemas europeus, dos quais ressalta o modelo dinamarquês e o norueguês. No primeiro, o acordo de 2 de outubro de 1970 resultou na obrigatoriedade de implantar um órgão de formação mista em todas as empresas com contingente mínimo de 50 pessoas. Já na Noruega, tornou-se obrigatória a criação de um comitê misto nos empreendimentos que contassem com pelo menos 100 empregados. ${ }^{53}$

\footnotetext{
${ }^{50}$ SIQUEIRA NETO, José Francisco. Liberdade sindical e representação dos trabalhadores nos locais de trabalho. São Paulo: LTr, 1999. p.160-161.

${ }^{51}$ OIT (1981), op. cit., p. 136-137.

${ }^{52}$ SIQUEIRA NETO, José Francisco, op. cit., p. 162-163.

${ }^{53}$ Ibid., p. 166.
} 
A temática recebeu suporte na legislação internacional, especialmente na Convenção n. $135^{54}$ sobre a proteção de representantes de trabalhadores, assim como pela Recomendação n. 143 sobre proteção e facilidades a serem dispensadas aos representantes de trabalhadores na empresa, ambas de 1971.

O art. $1^{\circ}$ da Convenção n. 135 dispõe acerca da necessidade de uma proteção eficiente aos representantes dos trabalhadores na empresa em face de condutas prejudiciais "motivadas por sua qualidade ou suas atividades como representantes dos trabalhadores, sua filiação sindical, ou participação em atividades sindicais, conquanto ajam de acordo com as leis, convenções coletivas ou outros arranjos convencionais".

Além disso, no art. 3ㄴ, o diploma designa os detentores da incumbência de representar os trabalhadores, quais sejam: os representantes sindicais (nomeados e eleitos por entidades sindicais) e os representantes eleitos (eleitos pelos trabalhadores da empresa e com previsão na normatização do país, não possuindo correlação com as prerrogativas adstritas às organizações sindicais).

Consoante a Recomendação n. 143, as medidas protetivas externam-se, principalmente, na justificação dos motivos propulsores à ruptura do vínculo contratual dos representantes dos trabalhadores, por exemplo: 1) a definição precisa e o detalhamento; 2) a exigência de consulta a um órgão independente, público ou privado antes de efetivar a dispensa; 3) a inversão do ônus da prova quando incorrer em dispensa supostamente discriminatória ou de mudança desfavorável das condições de emprego.

A Constituição Federal brasileira, no art. 11, prevê que "nas empresas de mais de duzentos empregados, é assegurada a eleição de um representante destes com a finalidade exclusiva de promover-lhes o entendimento direto com os empregadores". Trata-se de uma representação sem a participação sindical (formação exclusiva dos trabalhadores), por isso o legislador constituinte optou por não the conferir garantia de emprego similar ao do dirigente de sindicato. Ademais, imperioso destacar que o dispositivo constitucional não depende de regulamentação e faz parte das normas de aplicabilidade imediata.

\footnotetext{
${ }^{54}$ Ratificada pelo Brasil em 18 de maio de 1990 e publicada mediante o decreto n. 131, de 22 de maio de 1991.
} 
Apesar disso, no cenário prático, não se verificam muitas representações nesse sentido, sobretudo, esbarradas no fator cultural de que a representação satisfatória dar-se-á unicamente pela atuação das organizações sindicais, preconceito advindo, inclusive, de parte das entidades.

Para João Carlos Gonçalves, secretário-geral da Força Sindical, "[...] enquanto país democrático, avançamos até a porta da fábrica; da porta da fábrica, é impossível o sindicato entrar, a não ser por meio de seus associados ou dos delegados clandestinos [...]". ${ }^{55}$ Apesar desse cenário, cumpre enfatizar as primeiras negociações desse âmbito realizadas no setor de metalurgia ${ }^{56}$ do ABC paulista na década de 1980 .

O Anteprojeto de Lei de Relações Sindicais expõe detalhadamente a "representação dos trabalhadores nos locais de trabalho", a qual integra o sistema sindical e exerce suas atividades em colaboração com as entidades sindicais. Haverá somente uma representação por espaço laboral, por isso nas localidades onde prevalecer a formação plúrima a atuação ocorrerá de forma conjunta.

Anterior ao texto final da proposta apresentada ao Congresso Nacional, a organização dos trabalhadores no local de trabalho ocorreria por intermédio dos Comitês Sindicais de Empresa, cujas funções circundariam, por exemplo, a representação dos sindicatos e dos seus associados no empreendimento e nas demais instâncias do sindicato, tal qual a assunção das negociações coletivas. Evidentemente, o patronato insurgiu-se diante da possibilidade da presença sindical, salvo a escolha dos delegados coubesse ao arbítrio dos empregadores. ${ }^{57}$

No art. 62 do Anteprojeto de Lei, estão os objetivos da constituição de uma unidade de representação no local de trabalho, os quais se sublinham: I representar os trabalhadores perante a administração da empresa; II - aprimorar o

${ }^{55}$ GONÇALVES, João Carlos. Desafios e perspectivas para o diálogo social no brasil: o modelo sindical brasileiro e a reforma sindical. Revista do Tribunal Superior do Trabalho, Brasília, vol. 76, n. 4, p. 105-109, out/dez 2010. p. 107.

${ }^{56}$ José Francisco Siqueira Neto destaca que "a primeira Representação dos Trabalhadores (Comissão de Fábrica) negociada pelo sindicato dos trabalhadores data de 1981 (Ford). As demais representações foram instaladas, respectivamente, em 1982 (Volkswagem), 1983 (Saab Scania e 1984 (Mercedez-Benz). Posteriormente, todos os Acordos Coletivos de Trabalho foram renovados a cada dois anos". In: SIQUEIRA NETO, José Francisco, op. cit., p.364.

${ }^{57}$ AROUCA, José Carlos. Reforma da legislação sindical: relatório do Fórum Nacional do Trabalho: primeira leitura. LTr: revista legislação do trabalho. São Paulo, v.68, n.5, p.524-34, maio. 2004. p. 532. 
relacionamento entre a empresa e seus trabalhadores com base nos princípios da boa-fé e do respeito mútuo; III - promover o diálogo e o entendimento no ambiente de trabalho com o fim de prevenir conflitos.

Sem embargo, há o entendimento de que a proposta proclama a desvirtuação da representação no local de trabalho, analisada como uma mera substituição às antigas Comissões de Conciliação Prévia (CCP) e prejudicial à negociação coletiva, já que difunde a formação de sindicatos fracos. Assim, o "projeto fixa que ela poderá 'mediar e conciliar os conflitos individuais de trabalho' [...]. A redação lembra a triste experiência do 'sindicato-casa', que fragilizou e dividiu o sindicalismo no Japão". 58

De acordo com o art. 64, a unidade de representação será fixada por meio de iniciativa do sindicato de base ou ante a requisição de $20 \%$ dos empregados com mais de seis meses na empresa. Diversamente da permissão constitucional vigente, a qual condiciona a eleição de um representante a cada duzentos trabalhadores, o projeto assegura a constituição a partir de trinta empregados. Nos empreendimentos, cujo contingente seja inferior à apontada dezena, a criação da representação terá sua existência atrelada à autorização de um contrato coletivo.

O mandato do representante obedecerá ao interstício de três anos, o qual será respaldado pela garantia momentânea de emprego típica dos diretores sindicais. Além disso, gozará da inamovibilidade, isto é, não poderá sofrer transferência de unidade empresarial, salvo extinção do empreendimento. Outrossim, preserva-se o direito de opinião, tal como a garantia de publicar e distribuir material em prol dos trabalhadores.

Outro ponto inovador no âmbito da representação nos locais de trabalho refere-se à possibilidade de realização da negociação coletiva, pois, atualmente, o acordo e a convenção coletiva de trabalho são firmados exclusivamente pelos sindicatos das respectivas categorias. Segundo Otávio Pinto e Silva, a existência real de um processo negocial amplo está correlacionada à verdadeira liberdade

${ }^{58}$ BORGES, Altamiro, op. cit., p. 90. 
sindical, somada a um comportamento educacional e consciente da classe trabalhadora. ${ }^{59}$

Para Leôncio Martins Rodrigues, as representações locais foram fundamentais em alguns países da Europa, pois impediram quedas consideráveis nas taxas de sindicalização. Para tanto, o autor recorre aos estudos de Thomas Kochan e Kirsten Wever para explicitar que muitos debates acerca de questões estratégicas envolvendo a empresa são realizados em nível superior ao ambiente de trabalho. Por isso, a atuação da entidade sindical deve atingir patamares mais "baixos" que o típico acordo coletivo de empresa, fazendo-se presente ao cotidiano local e, desse modo, atender às novas conjunturas que abrangem o trabalhador. ${ }^{60}$

Apesar das inovações almejadas pelo Anteprojeto de Lei, a representação no local de trabalho enfrenta óbices decorrentes da indisposição do empregador frente à suavização do seu mando no ambiente de trabalho, seja pela participação dos empregados ou dos sindicatos. Houve inúmeros debates no Fórum Nacional do Trabalho sem a obtenção de consenso, já que o setor empresarial não acolheu a representação mediante a cooperação sindical; por outro lado, o sindicato vislumbra a atuação no local de trabalho como o prolongamento da sua operação. ${ }^{61}$

A participação sindical no âmbito da representação local é imprescindível à realidade brasileira, caso contrário, ter-se-á uma legislação sem efeitos práticos, já que o empregador continuará exercendo suas atividades em prol do capital. Nesse diapasão, Enoque Ribeiro dos Santos preceitua que o estabelecimento da representação no ambiente de trabalho, "certamente será ampliada e fortalecida com o advento da pluralidade sindical, que tornará a relação capital-trabalho muito mais equilibrada e democrática, com a inserção no novo cenário sindical brasileiro do sindicato por empresa". ${ }^{2}$

\footnotetext{
${ }^{59}$ SILVA, Otávio Pinto e. A contratação coletiva como fonte do direito do trabalho. São Paulo: LTr, 1998.

${ }^{60}$ RODRIGUES, Leôncio Martins. Destino do sindicalismo. São Paulo: Edusp, 1999. p. 204-205.

${ }^{61}$ ZYLBERSTAJN, Hélio, op. cit., p. 110.

${ }^{62}$ SANTOS, Enoque Ribeiro. Fundamentos do direito coletivo do trabalho nos estados unidos da América, na união européia, no mercosul e a experiência brasileira. Rio de Janeiro: Lumen Juris, 2005. p. 189-190.
} 


\title{
3.3 Reforma sindical brasileira e a busca pela liberdade plena
}

O sistema sindical brasileiro, exceto por ínfimas modificações, permanece sob o mesmo padrão há mais de meio século. Por outro lado, notoriamente as relações de trabalho estão em constante dinamicidade, assim, a visão tradicional dos atores sociais (empregado e empregador) da CLT já não denota a realidade, outras paisagens e personagens foram introduzidos no universo laboral. Nesse sentido, Eliana dos Santos Alves Nogueira alerta para a desproporcionalidade do projeto de lei em tramitação no Congresso Nacional, qual seja:

\begin{abstract}
O projeto de reforma sindical apresentado não vê esta realidade, já que continua se pautando pela criação de entidades sindicais apenas por empregados e não por trabalhadores de um modo geral. Neste sentido, referida reforma sindical deveria ter em mente essa grande parte dos trabalhadores brasileiros que, sindicalizando-se, poderiam estabelecer direitos mínimos, em contratos coletivos, para a grande rede de trabalhadores individuais, pessoais, que laboram como "autônomos" ou se perdem nas imensas redes de terceirização precária. ${ }^{63}$
\end{abstract}

Desse modo, quando se coteja o Direito Individual e o Direito Coletivo do Trabalho, torna-se evidente que o primeiro é constantemente atualizado para abarcar o maior número de situações; enquanto o segundo, não fossem as raras intervenções específicas do legislador e o esforço dos tribunais por meio da jurisprudência, permaneceria intacto aos moldes do Decreto-Lei n. 5.452/43, o qual estabeleceu o diploma celetista. Ademais, inúmeros dispositivos ${ }^{64}$ da CLT atrelados aos mecanismos sindicais encontram-se revogados tacitamente por não se correlacionarem aos preceitos constitucionais de 1988.

A celeuma sindical não se resume à necessidade de uma reforma na legislação infraconstitucional e na própria Constituição Federal, pois não basta apenas extinguir o conteúdo que emperra o estabelecimento da verdadeira

\footnotetext{
${ }^{63}$ NOGUEIRA, Eliana dos Santos Alves. Direito do trabalho e justiça do trabalho: panorama e perspectivas em face das atuais reformas. Revista do Tribunal Regional do Trabalho da 15a Região, Campinas, n.26, p.87-98, jan./jun. 2005. p. 97.

${ }^{64}$ Exemplos de artigos da CLT que se encontram prejudicados em decorrência da promulgação da Constituição Federal de 1988: art. 512; art. 515; art. 517 ao art. 521; art. 523 ao art. 532; art. 544; art. 553 ao art. 559; art. 564 ao art. 566; art. 570 ao art. 576; art. 600.
} 
liberdade sindical preconizada pela OIT, tais como: a unicidade, o enquadramento por categorias, o paralelismo simétrico e a contribuição compulsória. O novo sistema terá de enfrentar os estigmas culturais herdados do modelo corporativista, que afastou e fez o trabalhador desacreditar no movimento sindical, restando poucas entidades imbuídas na defesa dos ideais de uma classe.

Para tanto, José Carlos Arouca indaga:

\begin{abstract}
A quem interessa a reforma? Os trabalhadores não foram sensibilizados para defendê-la ou combatê-la, até porque a ignoram e os sindicatos que dela só tem notícias, pelas centrais, não se preocuparam em convocálos para discutir seu alcance. Pior de tudo é que a bancada dos trabalhadores chegou ao Fórum sem ter um projeto próprio para defender e dele saiu defendendo o projeto desenhado pelo governo. ${ }^{65}$
\end{abstract}

Diante disso, a organização atual não é preservada porque se mostra adequada aos trabalhadores, sua sobrevivência decorre da comodidade e do beneficiamento de setores conservadores. Posto isso, reformular ou adequar o sindicalismo não se trata de capricho, mas de uma imprescindibilidade.

Outrossim, justifica-se que o emperramento da reforma sindical brasileira deve-se a não ratificação da Convenção n. 87 da OIT, já que sua aprovação impulsionaria a implementação do modelo pluralista e, consequentemente, acarretaria a rivalidade entre as entidades, ou seja, a subsistência dependeria do abandono do comodismo atual, o qual não enseja a supressão territorial ou a queda das taxas de representação. ${ }^{66}$

A ausência de ratificação da citada Convenção não é a causa principal que impede a efetividade da liberdade sindical. Se a existência de diversas entidades sindicais fosse a resposta para a crise do sindicalismo brasileiro, não haveria inadequabilidade do sistema atual, composto por inúmeras organizações graças ao desmembramento de categorias.

Para Márcio Túlio Viana, o enaltecimento do supracitado diploma internacional, defendendo-o como meio de resolução dos entraves advindos do

\footnotetext{
${ }^{65}$ AROUCA, José Carlos (2004), op. cit., p. 534.

${ }^{66}$ NASCIMENTO, Amauri Mascaro (2007), op. cit., p. 651.
} 
monopólio sindical, certamente, impulsiona ao entendimento de que a aceitação do documento resultaria em um universo onde "tudo seriam flores". Nessa linha, o pluralismo representaria a efetividade da democracia, enquanto o monismo a encarnação da tirania ou do Estado fascista. ${ }^{67}$

$O$ autor se insurge acerca desse entendimento, o qual incute em "desviar o foco" dos problemas decorrentes da reestruturação produtiva, por exemplo. Para tanto, assevera que não se trata de uma opção entre a democracia ou o fascismo, "mas de encontrar a melhor estratégia para enfrentar problemas $\square$ antes de serem jurídicos $\square$ são políticos e, sobretudo econômicos". ${ }^{68}$

Segundo José Pastore, o alcance de um regime sindical livre depende do enfrentamento da problemática que envolve: o financiamento dos sindicatos; a organização das novas estruturas sindicais; a aferição da representatividade das entidades; a proteção do trabalho informal; a sobrevivência do sindicato na nova economia. ${ }^{69}$

Tal posicionamento converge para a reestruturação de todo o sistema sindical, com especial observação ao protecionismo dos trabalhadores marginalizados pela informalidade e a necessidade de entidades verdadeiramente representativas. Contudo, é preciso cautela com a inserção do sindicato em uma "nova economia", para que ele não seja vitimado pelo capital e se torne um simples pactuante dos interesses da classe patronal.

Hélio Zylberstajn esclarece que as modificações sindicais almejam desacelerar o processo de fragmentação representativa e, por consequência, a redução do número de entidades, visto que os organismos mais abrangentes incorporarão aqueles de menor amplitude, mas a sobrevivência daqueles está atrelada à condição de se tornarem representativos ou arcarem com a perda de exclusividade. A proposta do Fórum Nacional do Trabalho não vislumbra o destino das associações de trabalhadores terceirizados, contudo, a tendência é a ocorrência da supracitada absorção pelo ente mais amplo. ${ }^{70}$

\footnotetext{
${ }^{67}$ VIANA, Márcio Túlio (2004), op. cit., p. 1422.

${ }^{68}$ Ibid., p. 1422.

${ }^{69}$ PASTORE, José, op. cit., p. 86.

${ }^{70}$ ZYLBERSTAJN, Hélio, op. cit., p. 108 e 112.
} 
Evidentemente, o sindicato brasileiro necessita rever os ideais pelos quais foi criado e, assim, alçar novos objetivos que restabeleçam seu status. As baixas taxas de sindicalização e a ausência sindical em muitos setores são indicativos de que algo não está bem. Entretanto, mudanças estruturais súbitas podem surtir efeitos contrários ao almejado, uma vez que demandam amadurecimento de ideias e comportamentos. Não se pode olvidar que as novas e as tradicionais relações sindicais imploram o firmamento da liberdade sindical plena, diversamente da constatação contemporânea, a qual é mitigada, para não dizer inexistente.

Defender a propositura de um modelo reproduzido do direito comparado vai ao encontro da experiência em vigor, a qual foi copiada da estrutura italiana do período fascista e criou vida própria, adaptando-se ao "jeitinho brasileiro" de contornar os problemas sem thes dar solução adequada. Por isso, utilizar os ensinamentos estrangeiros requer o cuidadoso empenho de verificar a compatibilidade com os fatos sociais, políticos e econômicos brasileiros.

A PEC n. 369/05 e o Anteprojeto de Lei que a acompanha propugnam dar novo fôlego às entidades sindicais. Contudo, não fixará a "sonhada" liberdade sindical sem ressalvas apregoada pela Organização Internacional do Trabalho. A redação dos projetos demonstra a intenção de preparar um período de transição do regime antigo para o novo, mas em determinados pontos percebe-se a manutenção do conservadorismo mediante nomenclaturas modernas e rearranjos estruturais, além da ausência de muitos tópicos indispensáveis para uma reforma que hipoteticamente almeja o remodelamento.

Nesse sentido, analisa-se negativamente o modelo apresentado, particularmente pelo enquadramento sindical com "outra roupagem" e a concessão do registro das entidades a cargo do Ministério do Trabalho e Emprego. Ademais, no que diz respeito à exclusividade, trata-se da unicidade de base acobertada por denominação distinta. A base territorial das organizações sindicais continuará semelhante aos moldes atuais. ${ }^{71}$

${ }^{71}$ AROUCA, José Carlos (2004), op. cit., p. 527-529. 
Tal posicionamento é comprovado a partir da análise da documentação ${ }^{72}$ emitida pelo Ministério do Trabalho e Emprego, segundo o qual o novo modelo de organização sindical é um misto de unicidade com princípios de liberdade sindical. A primeira externa-se com a "exclusividade", a qual possibilita a permanência do monopólio de base às entidades existentes antes da aprovação da Lei, desde que comprovem a respectiva representatividade. Já a liberdade é notada pela existência simultânea de mais de uma entidade no mesmo âmbito de representação, desde que não haja entidades protegidas pela exclusividade.

Outrossim, Altamiro Borges ressalta:

Ao estimular a cizânia e a disputa na base de trabalhadores, gestando um Frankenstein sindical, o projeto já fragiliza o sindicalismo diante dos duros e inevitáveis confrontos em torno da reforma trabalhista. Para piorar, o governo ainda retirou do seu projeto o único dispositivo que dava uma tímida segurança frente à flexibilização - que consagrava "o princípio do uso da norma mais benéfica ao trabalhador", capitulando diante do uso da norma mais benéfica ao trabalhador", capitulando diante da pressão patronal. [...] A aprovação da PEC, que antecipa a votação do projeto de lei, viabilizaria o império da desregulamentação do trabalho e propicia a "prevalência do negociado sobre o legislado" - agora embalada na ideia da livre negociação. ${ }^{73}$

A ANAMATRA propõe a reforma sindical a partir de pontos não elencados ou com tratativa diversificada pelo relatório do FNT, bem como das propostas. A associação sustenta a revisão da estrutura sindical, a representação dos trabalhadores na empresa, a negociação coletiva, o direito de greve e o dissídio coletivo. Quanto à estrutura do sindicalismo, defende-se, por exemplo, o impedimento da dispensa arbitrária e a defesa dos indivíduos excluídos do mercado formal de trabalho, tal como o estabelecimento de uma relação duradoura entre as entidades de cúpula e de base. ${ }^{74}$

No que diz respeito à representação em âmbito local, objetiva-se a implantação de um regime empresarial democrático, isto é, o qual seja partilhado o poder diretivo e a concretude dos direitos individuais, evitando o

\footnotetext{
${ }^{72}$ FNT. Espaço de diálogo e negociação. Reforma sindical: perguntas e respostas. 2.ed. rev. e atual. Brasília: Ministério do trabalho e emprego, 2005. p. 18.

${ }^{73}$ BORGES, Altamiro, op. cit., p. 92-93.

${ }^{74}$ VIANA, Márcio Túlio (2004), op. cit., p. 67.
} 
reconhecimento de uma representação meramente homologatória de renúncias e transações. Ademais, defende-se a importância da negociação coletiva, a manutenção dos efeitos erga omnes e a permanência da ultratividade das normas coletivas. $^{75}$

A reforma sindical almejada e substanciada pela citada proposta carece de revisão em alguns pontos, para que a posteriori não se vislumbre um novo sistema inadequado aos anseios da coletividade trabalhista. Esse processo de revisão não ocorrerá sem desgastes, porquanto, durante as negociações do FNT, certas instituições pretendiam a conservação do modelo defasado atual. Indubitavelmente, há de se fazer concessões, desde que não ocasionem a precarização das relações.

Reformar não é uma empreitada de realização inteligível, cita-se como exemplo a América Latina. Posteriormente às suas revisões, constataram-se inúmeras entidades sindicais fracas e com índices reduzidos de filiação. Todavia, não é possível relacionar tais fatos ao remodelamento sindical, que ocasionou o fortalecimento das relações de trabalho na empresa, mas em países com grande concentração de pequenas e médias empresas houve um encolhimento da atuação dos sindicatos. ${ }^{76}$

Para María Luz Vega Ruiz, os efeitos de uma reforma trabalhista não podem ser facilmente mensurados, visto que muitas falhas atribuídas ao direito material, efetivamente, estão vinculadas a falhas na aplicação legal ou procedimentos administrativos e judiciais. Por isso, "la búsqueda de la inmediatez, la simplicidad y la transparencia, bajo la vigilancia de los interlocutores sociales, pudiera conducir a uma nueva etapa, más satisfactoria, de regulación de las relaciones de trabajo". ${ }^{77}$

Assim, a reforma sindical ambicionada pela PEC n. 369/05 em tramitação no Congresso Nacional e o Anteprojeto de Lei de Relações Sindicais não favorecem o estabelecimento da liberdade sindical plena, sequer oportunizam a ratificação da Convenção n. 87 da OIT. Ademais, a tentativa de fazer prevalecer o negociado sobre o legislado deve ser posta em xeque, caso contrário, ensejará

\footnotetext{
${ }^{75}$ VIANA, Márcio Túlio (2004), op. cit., p. 69.

${ }_{77}^{76}$ VEGA RUIZ, María Luz, op. cit., p. 93.

${ }^{77}$ Ibid., p. 95.
} 
a precarização de direitos trabalhistas e desvirtuará a negociação coletiva, instrumento cujo propósito essencial é o assentamento da melhoria das condições de trabalho e não a flexibilização.

\subsection{Perspectivas de aprovação da PEC}

A ascensão à Presidência da República de Luiz Inácio Lula da Silva $^{78}$, ex-sindicalista e militante do Partido dos Trabalhadores, foi vislumbrada como cenário ideal para o reavivamento da reforma sindical desejada há décadas, principalmente pela classe trabalhadora.

Conforme exposto anteriormente, o mencionado anseio resultou em diversas discussões no Fórum Nacional do Trabalho pelos representantes dos principais setores interessados, quais sejam: empregados, empregadores e governo. No término dos debates, compilou-se um relatório final, o qual foi submetido à apreciação do Poder Executivo e deu origem à PEC n. 369/05 e ao Anteprojeto de Lei de Relações Sindicais.

A PEC foi apresentada à Câmara dos Deputados em 04 de março de 2005 e lá permanece sob vagaroso andamento processual, o qual se movimentou pela última vez em 20 de junho de 2013 com a solicitação do seu apensamento à PEC n. 314/2004. Aparentemente, o desejo reformista está adormecido diante do conflito de interesses, e de acordo com alguns recortes da época da apresentação a seguir expostos.

Para Amauri mascaro Nascimento, não é possível apontar os rumos da proposta elaborada pelo FNT, especialmente pela falta de apoio político das entidades sindicais, seja de trabalhadores ou empregadores que se dividiram e indicaram modificações somente após a conclusão das etapas do Fórum. Nessas

\footnotetext{
${ }^{78}$ Para Altamiro Borges, "alguns setores apostaram que o governo Lula abriria uma chance histórica para promover avanços na legislação. Afinal, o presidente se projetou na luta operária e sempre defendeu o fortalecimento do sindicalismo; já os neoliberais, que nunca esconderam seu ódio às entidades de classe, foram derrotados nas urnas. Essa seria uma oportunidade impar para conquistar a legalização das centrais, a organização no local de trabalho e outros avanços. Não podia ser desperdiçada." In: BORGES, Altamiro, op. cit., p. 84-85.
} 
circunstâncias, a aprovação da reforma sindical depende de "profundas alterações". ${ }^{79}$

De acordo com o material produzido pelo Ministério do Trabalho e Emprego durante reuniões do FNT, as confederações ${ }^{80}$ se insurgiram para que não ocorresse a promoção de mudanças bruscas à estrutura existente e, de modo inexorável, fosse priorizada a continuidade da unicidade, a forma de arrecadação e o poder normativo da Justiça do Trabalho. Tais acontecimentos tornaram infrutíferas as conversações das referidas entidades com o restante das organizações. $^{81}$

A Fecomercio (Federação do Comércio de Bens, Serviços e Turismo do Estado de São Paulo) reuniu sindicalistas e discutiu uma proposta alternativa à apresentada pelo Poder Executivo, a qual foi rotulada de "centralizadora e mais intervencionista", alinhada aos interesses da classe patronal. A federação não vislumbrou sequer a correção da proposta governamental e defendeu a rejeição total do documento e acentuou os seguintes pontos, entre outros: permanência da unicidade; liberdade sindical sem interferência estatal; registro sindical a cargo das organizações, sem intervenção do Ministério do Trabalho e Emprego (autogestão do sistema); arrecadação compulsória das contribuições de natureza confederativa e de negociação coletiva. ${ }^{82}$

O posicionamento da Fecomercio prega a manutenção do corporativismo, já que a manutenção do monopólio de representação e a pretensão de uma liberdade sindical sem a interveniência do Poder Público são institutos jurídicos que se contrapõem. Primeiramente, porque a unicidade surge a partir de um imperativo legal, em seguida, pelo motivo de que em um sistema livre não há que se falar em "escolher" a única entidade existente na base de

\footnotetext{
${ }^{79}$ NASCIMENTO, Amauri Mascaro. Compêndio de direito sindical. 7.ed. São Paulo: LTr, 2012. p. 657.

${ }^{80}$ Nesse sentido: "[...] apenas as grandes centrais sindicais estão aprovando integralmente as novas regras. O texto tem sido bombardeado por antigas e carcomidas confederações de trabalhadores que perderão poder e os recursos do chamado imposto sindical compulsório que hoje as mantém.

Centrais e sindicatos com menor expressão política condenam o poder que será atribuído às grandes centrais". In: DIANEZI, Vicente. Buraco Negro. Reforma sindical do governo corre risco de engavetamento. Revista Consultor jurídico, 29 abr. 2005. Disponível em:

<http://www.conjur.com.br/2005-abr-29/reforma_sindical_governo_corre_risco_engavetamento>.

Acesso em: maio 2014.

${ }^{81}$ FNT, op. cit., p. 11.

${ }^{82}$ FECOMERCIO. Fecomercio propõe alternativa ao projeto de reforma sindical. Tome Nota.
}

Informativo de legislação trabalhista, previdenciária e sindical, n. 20, São Paulo, maio 2005. 
representação. Para tanto, cumpre observar o entendimento da Organização Internacional do Trabalho:

[...] puede ser ventajoso para los trabajadores y los empleadores evitar la multiplicación del número de organizaciones defensoras de sus intereses, toda situación de monopolio impuesta por vía legal se halla en contradicción con el principio de la libertad de elección de las organizaciones de empleadores y de trabajadores. ${ }^{83}$

Quanto ao registro sindical, o Comitê de Liberdade Sindical dispõe que "el registro de los sindicatos consiste únicamente en una formalidad cuyas condiciones no son de tal naturaleza que pongan en peligro las garantías previstas por el Convenio" (Convenção n. 87). ${ }^{84}$

Consoante matéria publicada no Jornal Folha de São Paulo, representantes da CNI (Confederação Nacional da Indústria) e da Fiesp (Federação das Indústrias do Estado de São Paulo) informaram, durante o seminário sobre reforma sindical em São Paulo, que "sem reforma trabalhista, a reforma sindical não sai", em decorrência da possibilidade de se perder investimentos. A classe empresarial criticou principalmente a substituição processual prevista no projeto, creditando-lhe aumento dos custos de produção e maior estímulo aos conflitos. Quando indagado sobre a hipótese de frustrar a reforma, Paulo Skaf (presidente da Fiesp à época), advertiu sobre "uma articulação política forte nos corredores do Congresso". ${ }^{85}$

À época da apresentação da PEC, 1/3 dos membros do Congresso Nacional eram desfavoráveis à aprovação da proposta advinda das discussões do FNT, especialmente partidos como PCdoB, PDT, PTB, PSB e PMDB. De acordo com o PCdoB, a proposta significa um retrocesso à Constituição Federal de 1988, pois favorece a desregulamentação de direitos trabalhistas, fragmenta as organizações sindicais e restringe o direito à greve. Já a bancada do PDT classificou a reforma como uma desnecessidade imediata, além disso, carecia de

${ }^{83}$ OIT. La libertad sindical. Recopilación de decisiones y princípios del Comité de Libertad Sindical del Consejo de Administración de la OIT. 5.ed. rev. Ginebra: Oficina Internacional del Trabajo, 2006. Párrafo 320. p.71.

${ }^{84}$ Ibid., párrafo 294. p. 65.

${ }^{85}$ ROLLI, Claudia. Reforma sindical vai aumentar custos, diz indústria. Folha de São Paulo, Mercado, São Paulo, 16 mar. 2005. Disponível em: < http://www1.folha.uol.com.br/fsp/dinheiro/fi1603200516.htm>. Acesso em maio 2014. 
debates entre entes de base. O PSB defendeu a continuidade da unicidade sindical como forma de evitar a dispersão dos trabalhadores. ${ }^{86}$

São citados três motivos que dificultaram a aprovação da reforma sindical ainda durante o período do "Governo Lula", quais sejam: 1) a inabilidade política dos interlocutores do Ministério do Trabalho e Emprego; 2) a resistência de parcela expressiva do movimento sindical; 3) a crise política. Nesse contexto, o FTN excluiu a participação das confederações, dos trabalhadores rurais e de servidores públicos. A restrição ao sistema confederativo fez com que suas entidades criassem o Fórum Sindical dos Trabalhadores (FST) como instância alternativa para debater a estrutura sindical. Ademais, o Governo descuidou-se com relação às articulações prévias no Congresso Nacional, o que ocasionou a contrariedade até dos partidos da base governamental. ${ }^{87}$

Para José Maria de Almeida (o Zé Maria), a reforma sindical indica prejudicial tolhimento de direitos trabalhistas solidificados no decorrer da história, especialmente pela instituição do "negociado sobre o legislado" e a exclusão do princípio da norma mais favorável. Outrossim, explica que a proposta favorece as cúpulas das centrais sindicais sob o argumento simulado de eliminar sindicatos pelegos e taxas compulsórias. Ademais, a classe empresarial ambiciona uma reforma trabalhista concomitante a sindical, objetivando a retirada de direitos. ${ }^{88}$

Ante os fatos apresentados, verifica-se que o trabalhador não é o ponto central de preocupação da maioria das instituições elencadas, o receio delas é fixado na perda de representatividade, diminuição do valor destinado pela contribuição sindical, redução dos custos com mão de obra em prol à obtenção de maior lucratividade, enfim, nota-se que a oportunidade de debates oferecida pelo FNT não favoreceu o consenso, apenas clarificou os interesses de cada parte.

${ }^{86}$ VERLAINE, Marcos. Reforma sindical: $1 / 3$ do Congresso é contrário ao texto produzido pelo FNT. Departamento Intersindical de Assessoria Parlamentar, Brasília, 08 maio 2005. Disponível em: $<$ http://www.diap.org.br/index.php?option=com_content\&view=article\&id=5665:reforma-sindical-13-docongresso-e-contrario-ao-texto-produzido-pelo-fnt\&catid=46\&ltemid=207>. Acesso em maio 2014.

${ }^{87}$ QUEIROZ, Antônio Augusto de. As razões da derrota do Governo na reforma sindical.

Departamento Intersindical de Assessoria Parlamentar, Brasília, 23 fev. 2006. Disponível em: $<$ http://www.diap.org.br/index.php?option=com_content\&view=article\&id=5582:as-razoes-daderrota-do-governo-na-reforma-sindical\&catid=46\&ltemid=207>. Acesso em maio 2014.

${ }^{88}$ ALMEIDA, José Maria de. Reforma sindical cria superpelegos. Folha de são Paulo, Opinião, São Paulo, 21 abr. 2005. Disponível em:

<http://www1.folha.uol.com.br/fsp/opiniao/fz2104200510.htm>. Acesso em maio 2014. 
O dissenso entre as classes é uma das causas de emperramento da proposta de reforma sindical. Evidentemente, os projetos carecem revisões importantíssimas, visto que nos moldes apresentados não vislumbram a liberdade sindical plena e denotam retrocesso em determinados itens, como a atribuição de exclusividade. Ademais, a estrutura sindical atual é cômoda a muitos grupos, especialmente a certas entidades patronais que se sobrepõem aos direitos trabalhistas e às organizações de trabalhadores sem expressividade. 


\title{
CAPÍTULO 4 PROTEÇÃO CONTRA ATOS E CONDUTAS ANTISSINDICAIS NO ORDENAMENTO JURÍDICO BRASILEIRO E COMPARADO
}

\subsection{Violações à liberdade sindical: aspectos gerais}

A liberdade sindical reconhecida como um direito humano fundamental deve ser garantida em qualquer Estado democrático mediante instrumentos eficazes de proteção em face dos denominados atos antissindicais. Nesse sentido, Walküre Lopes Ribeiro da Silva leciona:

\begin{abstract}
Tratando-se de direito de natureza fundamental, seu exercício deve ser assegurado por meios enérgicos, para que não seja direito existente apenas em caráter formal, devendo ser protegido para que o regime de sua fundamentalidade seja material, tal qual um direito deste quilate pede. [...] $\mathrm{O}$ ato antissindical é aquele que vem desafiar o exercício da liberdade sindical em suas mais variadas formas. ${ }^{1}$
\end{abstract}

Para Gino Giugni, "a mera existência da norma jurídica não é ainda, de fato, elemento suficiente para adequar a ela o dano real. Se isto é verdadeiro em geral, para o direito sindical o é particularmente enquanto regula relações fortemente conflituais". Por isso, demanda a presença de instrumentos eficazes e garantidores da liberdade sindical, pois a previsão de certas violações no tipo penal é uma medida insuficiente, uma vez que o empregador, detentor dos meios de produção e organizador de toda a estrutura empresarial, poderá utilizar sua força para evitar (ser um obstáculo) a aplicação legal pró-trabalhador. Os prejuízos serão intensificados se a entidade sindical representativa dos trabalhadores não atuar de forma diligente. ${ }^{2}$

\footnotetext{
${ }^{1}$ SILVA, Walküre Lopes Ribeiro da; LIMA, Firmino Alves. Repressão penal dos atos antissindicais. Revista do Tribunal Regional do Trabalho da 15a Região, Campinas, n. 37, p. 67-84, 2010. p. 70-71.

2 GIUGNI, Gino; CURZIO, P.; GIROFALO, M. G. Direito Sindical. Trad. Eiko Lucia Itioka. Rev. José Francisco Siqueira Neto. São Paulo: LTr, 1991. p. 87.
} 
A liberdade sindical pode ser atacada por incontáveis ofensas, as quais podem manifestar-se por meio de atos de extrema violência. O Comitê de Liberdade Sindical verificou, especialmente a partir de meados da década de 1990, o melhoramento das condições sindicais na América Latina. Doravante, observou-se a elevação do respeito aos direitos humanos, civis e políticos. Por outro lado, a violência antissindical aperfeiçoou-se e sua identificação nas relações trabalhistas foi dificultada, diversamente das manifestações ocorridas no passado. Antes, tolerava-se a antissindicalidade, por vezes, consequente da atividade estatal; hoje, a violência é diagnosticada, inclusive em face do Estado e atinge entidades sindicais, bem como as demais instituições e grupos sociais. ${ }^{3}$

Por isso, garantir a liberdade sindical não é uma medida exclusivamente reparatória dos atos considerados atentatórios, outrossim, importa no estabelecimento de instrumentos preventivos. ${ }^{4}$

Os mecanismos protetivos de liberdade sindical e as suas violações diversificam-se de acordo com o país e o sistema legal vigente, assim como pelo modelo de organização sindical adotado. Sendo assim, convém realizar o esclarecimento acerca de alguns dos institutos recorridos veementemente.

De acordo com Luciano Martinez, a antissindicalidade e o antissindicalismo, apesar de receberem designação similar, são termos distintos. $O$ primeiro termo consiste na ofensividade em relação à organização ou à ação sindical, conquanto advinda de uma "atuação isolada ou de uma atividade concertada com fins especificadamente definidos". Já o segundo vocábulo denota a

\footnotetext{
Para José Francisco Siqueira Neto, as disparidades nas relações trabalhistas, principalmente quanto à classe empregadora e ao poder que exerce sobre os trabalhadores. Igualmente, enfatiza a indispensabilidade de corrigir tais distorções, para tanto, primeiramente, há que se constatar as desigualdades dessa conjuntura, sejam aquelas de ordem social, econômica, política, jurídica e, em especial o reconhecimento do conflito entre os atores sociais, pois a "negação do conflito leva, inexoravelmente, a saídas autoritárias e à imposição da vontade de uma parte - na maioria das vezes os empregadores - sobre a outra. Posteriormente, defende-se a liberdade sindical e a representação dos trabalhadores por local de trabalho como instrumento corretivo às discrepâncias elencadas, desde que haja ambiente favorável ao diálogo e confronto positivo entre os interessados. In: SIQUEIRA NETO, José Francisco. Liberdade sindical e representação dos trabalhadores nos locais de trabalho no Brasil: obstáculos e desafios. In: PEREIRA, Armand F. (Org.). Reforma sindical e negociação coletiva. Brasília: OIT, 2001. p. 81-82.

3 BRONSTEIN, Arturo S. In: ERMIDA URIARTE, Oscar; OJEDA AVILÉS, Antonio. (Coord.) EI derecho sindical em america latina. Montevideo: Fundación de Cultura Universitaria, 1995. p. 88.

${ }^{4}$ GARCIA, Gustavo Filipe Barbosa. Liberdade sindical: condutas antissindicais e atuação do Ministério Público do Trabalho. Revista Justiça do Trabalho, Porto Alegre, v.30, n.358, p.7-18, out. 2013. p. 17.
} 
propositura de entraves ao sindicalismo "como um movimento que dá suporte à ação social, reivindicatória ou política" de realização dos organismos sindicais. O autor informa que existe a "antissindicalidade lato sensu", a qual se bifurca em "antissindicalidade stricto sensu" (formada por atos antissindicais simples) e "antissindicalismo" (caracterizada por atos complexos). ${ }^{5}$

A antissindicalidade apresenta-se de forma ostensiva quando se coloca de maneira intolerante e sob proibições, tal como a Lei Le Chapelier. Outrossim, a aludida violação poderá repercutir por intermédio de controle direto (característica de regimes totalitários), pelo qual o ente estatal contorna os conflitos sindicais intencionando a sua minimização e, por conseqüência conduzi-lo à extinção, tal qual as ocorrências espanholas no período franquista. Não se pode olvidar da antissindicalidade exercida por controle externo, cuja execução transcorre mediante instrumentos fraudulentos e clandestinos, como a normatização coletiva benéfica exclusivamente aos associados. ${ }^{6}$

O praticante da antissindicalidade é aquele que por meio de:

[...] ação ou omissão, independentemente da constatação de culpa, violar direitos de liberdade sindical. A culpa ou o dolo qualificará, evidentemente, o ilícito civil-trabalhista aqui em análise. [...] a caracterização de uma conduta como antissindical dependerá fundamentalmente da natureza da lesão que afete o sujeito sindical. Dizse isso porque somente as condutas geradoras de lesões antijurídicas [...] poderão ser entendidas como suficientes à caracterização da antissindicalidade. ${ }^{7}$

A configuração da subjetividade dos atos antissindicais não se faz necessária para a verificação da violação da liberdade sindical, isto é, não importa a intencionalidade do agente. Sendo assim, estará caracterizada a ofensa de procedência direta ou indireta. Desse modo, reflete uma ação comportamental ativa ou omissiva "por parte do empregador ou de outros grupos interessados na relação, que venham a destruir, mitigar ou tornar sem efeito a liberdade sindical em suas diversas formas de expressão".

\footnotetext{
${ }^{5}$ MARTINEZ, Luciano. Condutas antissindicais. São Paulo: Saraiva, 2013. p. 168-169.

${ }^{6}$ Ibid., p. $172-180$.

${ }^{7}$ Ibid., p. 216-217.

${ }^{8}$ SILVA, Walküre Lopes Ribeiro da; LIMA, Firmino Alves, op. cit., p. 75-76.
} 
No magistério de Oscar Ermida Uriarte:

[...] alguns dos atos antissindicais derivam de legislação ou atos estatais ou ainda de climas políticos que impedem ou limitam a liberdade sindical, direta ou indiretamente. Outros são produtos de práticas desleais, de atos de ingerência ou de discriminação no emprego. Conseqüentemente, a proteção contra atos ou práticas anti-sindicais, inclui toda medida tendente a evitar reparar ou sancionar qualquer ato que prejudique indevidamente $o$ trabalhador ou as organizações sindicais no exercício da atividade sindical ou a causa desta ou que lhes negue injustificadamente as facilidades ou prerrogativas necessárias para 0 normal desenvolvimento da ação coletiva. ${ }^{9}$

Desse modo, a expressão "conduta antissindical", muitas vezes disposta nos ordenamentos jurídicos, possui significado amplo, uma vez que compreende o foro sindical (empregado em países latinos como Venezuela e Colômbia) e as práticas desleais de origem norte-americana. Inicialmente, o foro sindical consistia apenas no sistema protetivo do dirigente sindical, em seguida, estendeu-se o conceito a qualquer trabalhador que desempenhasse atividades sindicais. $^{10}$

O foro sindical e as práticas desleais utilizados como meio de combate às violações da liberdade sindical agrupam medidas com o almejo de prevenção, reparação ou sanção que possam lesionar a classe trabalhadora, assim como as entidades representativas, favorecendo a atuação sindical e coletiva. Mas, em decorrência da escassez de legislação brasileira apropriada nesse sentido, a negociação coletiva tem se mostrado instrumento de elevada importância. Para tanto, há que se valorizar a representação no local de trabalho preceituada pelo art. 11 da Constituição Federal brasileira, já que beneficia tanto os empregados quanto os sindicatos, dificultando, por exemplo, o assédio moral e sexual, tal como diversas práticas antissindicais. ${ }^{11}$

Já as práticas desleais provenientes da Lei Wagner (1935, Estados Unidos) dizem respeito ao comportamento dos empregadores relacionado à

\footnotetext{
${ }^{9}$ ERMIDA URIARTE, Oscar. A proteção contra os atos anti-sindicais. Trad. Irany Ferrari. São Paulo: LTr, 1989. p. 17.

${ }^{10}$ BARROS, Alice Monteiro de. Condutas anti-sindicais - procedimento. Revista do Tribunal

Regional do Trabalho da 3a Região, Belo Horizonte, n. 59, p. 29-44, jan./jun. 1999. p. 29.

${ }^{11}$ PEREIRA, Ricardo Jose Macedo de Britto. Novas perspectivas do direito coletivo do trabalho no Brasil. In: SANTOS, Élisson Miessa; CORREIA, Henrique. Estudos aprofundados MPT:

Ministério Público do Trabalho. Salvador: JusPODIVM, 2012. p. 421-423.
} 
interferência na entidade sindical de trabalhadores, no emperramento de direitos sindicais e na recusa ao firmamento de negociações. Em junho de 1947, o Congresso estadunidense aprovou a Lei Taft-Hartley, que acrescentou as organizações sindicais de empregados ao rol de entidades praticantes de atos desleais. $^{12}$

Frequentemente, utilizam-se coações de ordem física e econômica, que se externam, por exemplo, em decorrência de ameaças para que o trabalhador abandone os movimentos paredistas ou pelo oferecimento de vantagens financeiras. ${ }^{13}$

No que diz respeito à discriminação, apresenta-se sob a ótica direta, indireta e oculta. $\mathrm{O}$ ato discriminatório direto reside no procedimento díspar estabelecido a partir de razões proibidas, já a discriminação indireta assenta-se em normas neutras com prejuízo a determinado grupo, enquanto a sua face oculta é caracterizada pela intenção direta sobreposta por outras justificativas. ${ }^{14}$

Nesse diapasão, ao empregador é defesa a utilização de meios discriminatórios em qualquer fase da relação contratual trabalhista. Assim, não se pode inserir empecilhos na contratação, dispensa, pagamento da remuneração e de vantagens sociais a quaisquer indivíduos com atuação sindical, seja diretor, representante ou militante. ${ }^{15}$

Tradicionalmente, Mauricio Godinho Delgado explica a violação à liberdade sindical a partir de dois sistemas, quais sejam as cláusulas de segurança e as práticas antissindicais. As primeiras elencam hipóteses incentivadoras à sindicalização; mas, são verdadeiros artifícios que forçam o trabalhador a se filiar. Nesse sistema, estão inclusas as afamadas cláusulas: close shop, union shop, preferencial shop e a maintenance of membership. ${ }^{16}$

No que tange às práticas antissindicais, exercem papel diametralmente oposto, isto é, desestimulam a sindicalização e, por consequência, impulsionam o

\footnotetext{
${ }^{12}$ BARROS, Alice Monteiro de (1999), op. cit., p. 30.

${ }^{13}$ MENEZES, Cláudio Armando Couce de. Proteção contra condutas anti-sindicais (atos antisindicais, controle contra discriminação e procedimentos anti-sindicais). Revista do Tribunal Superior do Trabalho, Brasília, vol. 71, n. 2, p. 44-55, maio/ago. 2005. p. 46.

${ }^{14}$ ARAUJO, Adriane Reis de. A liberdade sindical e os atos anti-sindicais no direito brasileiro. Revista do Ministério Público do Trabalho, Brasília, ano XVI, n. 32, p. 29-48, out. 2006. p. 37.

${ }^{15}$ MENEZES, Cláudio Armando Couce de, op. cit., p. 47.

${ }^{16}$ DELGADO, Mauricio Godinho. Curso de direito do trabalho. 12.ed. São Paulo: LTr, 2013. p. 1344.
} 
enfraquecimento das organizações sindicais, sendo as mais conhecidas: yellow dog contracts, company unions e mise à l'index. Sendo assim, ambos os modelos conduzem ao desrespeito da livre sindicalização. ${ }^{17}$

\subsubsection{Mecanismos protetivos}

No que tange aos instrumentos de defesa da liberdade sindical, normalmente, os Estados a tutelam por meio da esfera administrativa, cíveltrabalhista e penal. Na primeira hipótese, os atos antissindicais são atacados por intermédio de métodos não judiciais, como ocorre nos Estados Unidos, onde, inicialmente, instaura-se um procedimento administrativo. Quanto à segunda hipótese, cita-se a título exemplificativo a Espanha, cuja legislação prevê a interposição do recurso de amparo pelo indivíduo lesionado. No que diz respeito à proteção penal, a tipificação ocorre em diversos ordenamentos com o intento de constringir o empregador a obedecer ao supracitado direito. ${ }^{18}$

Os mecanismos de proteção estão presentes em todas as fases de exteriorização da liberdade sindical, assim, são encontrados desde a constituição do sindicato, tal qual no decorrer do exercício das funções de direção ou representação da entidade. Dessa maneira, sob a perspectiva individual o empregado estará protegido do registro da candidatura (anterior ao exercício) até um ano após o término do mandato do cargo sindical (posterior às atividades), enquanto o restante da classe obreira está amparado pela liberdade sindical positiva e negativa, isto é, o direito de se filiar ou se desfiliar de uma organização. ${ }^{19}$

Evidentemente, o sistema protetivo não se resume ao mero abarcamento do direito de filiação e desfiliação às entidades sindicais, mas estão embutidas todas as hipóteses que estejam relacionadas, direta ou indiretamente, como a garantia do exercício de greve.

\footnotetext{
${ }^{17}$ DELGADO, Mauricio Godinho, op. cit., p. 1345.

${ }^{18}$ SILVA, Walküre Lopes Ribeiro da; LIMA, Firmino Alves, op. cit., 76-78.

${ }^{19}$ ARAUJO, Adriane Reis de, op. cit., p. 39.
} 
Alice Monteiro de Barros alerta para a antissindicalidade ocorrida na fase pré-contratual, tratando-a como o tipo mais temerário e pérfido, pois 0 empregador declina à contratação em decorrência do engajamento sindical e, especialmente devido à filiação. A ausência de mecanismos de proteção demonstra a complexidade para a aferição de provas da conduta prejudicial, por vezes, ocultada por manobras "aparentemente lícitas", visto que a contratação de um trabalhador "manifesta-se dentro de um contexto discricionário, capaz de conduzir a uma vertente psicológica e subjetiva de difícil controle, colocando o empregador em posição inicialmente vantajosa". ${ }^{20}$

Isso significa que, em dadas circunstâncias, dificilmente haverá a comprovação da conduta nociva do empregador, devido aos subterfúgios utilizados para negar a admissão do militante sindical, exceto quando a violação seja explícita, tal como ocorreu no estado de Minas Gerais, onde determinada empresa foi condena pela Justiça Trabalhista ${ }^{21}$ em danos morais coletivos pela prática de conduta antissindical. $O$ ato ofensivo consistia na exigência do futuro trabalhador de firmar declaração, no momento da contratação, de que não integrava qualquer diretoria, conselho sindical ou associação de qualquer natureza.

Nessa linha, o TST possui Orientação Jurisprudencial n. 20 da SDC, a qual indica violação do art. $8^{\circ}, \mathrm{V}$, da CF (direito de filiação e desfiliação), a normatização coletiva que incute na admissão de trabalhador sindicalizado em detrimento de outros não filiados.

Por isso, há que se garantir a liberdade sindical por intermédio de ações preventivas, reparatórias e inibitórias. A tutela de prevenção consiste em atos cuja execução depende de comunicação ou autorização, assim como de agentes fiscalizadores de órgãos judiciários, administrativos ou sindicais. Já a

${ }^{20}$ BARROS, Alice Monteiro de (199), op. cit., p. 33.

21 [...] CONDUTA ANTISSINDICAL. INDENIZAÇÃO POR DANO MORAL COLETIVO. POSSIBILIDADE. A egrégia Corte Regional consignou que a ré, ao contratar seus empregados, exigia que eles firmassem um termo declarando não fazerem parte de diretoria ou organização sindical. Concluiu, então, que tal conduta se caracterizava como antissindical, porquanto tinha o condão de afastar os empregados dos órgãos representativos da categoria profissional correspondente, afrontando, assim, o princípio da liberdade sindical. Nesse passo, condenou a ré ao pagamento de dano moral coletivo, no montante de $R \$ 300.000,00$ (trezentos mil reais), reversíveis ao FAT - Fundo de Amparo ao Trabalhador. [...] (TST, RR - 51500-08.2005.5.03.0007, Relator Ministro: Guilherme Augusto Caputo Bastos, Data de Julgamento: 24/11/2010, 2a Turma, Data de Publicação: DEJT 17/12/2010) 
reparação decorre da atuação após a violação da liberdade sindical, geralmente, por meio da determinação de nulidade do ato, bem como pelas consequências indenizatórias. O mecanismo inibitório efetiva-se depois do ato antissindical e objetiva sua sustação, "melhor do que o pagamento de qualquer quantia para o ressarcimento do prejuízo com o desrespeito ao direito fundamental da liberdade sindical é a célere anulação de seus efeitos". 22

Ressalta-se a suspensão do ato antissindical como medida eminente de evitar a propagação dos seus efeitos danosos. Ademais, destaca-se a utilização de procedimentos processuais específicos como a inversão do ônus probatório, haja vista a simples propensão do empregador à formação do conjunto de provas e a complexidade do trabalhador e da organização sindical obreira. ${ }^{23}$

Costumeiramente, acentua-se a proteção doméstica e internacional contra os atos antissindicais violadores da dignidade dos indivíduos inseridos na típica relação de trabalho. Entretanto, olvida-se dos atores sociais não pertencentes ao mercado formal, fato que os impossibilita de exercer direitos sindicais básicos. Propugna-se uma releitura desse cenário, para que esses trabalhadores tenham garantida sua dignidade, apesar da disposição na informalidade, assim como em situação de desemprego. Caso contrário, o Estado poderá ser responsabilizado pela prática de antissindicalidade, já que "limita a preservação das liberdades sindicais e a proteção contra a prática de atos anti-sindicais apenas para os que se encontram vinculados por um elo de subordinação". ${ }^{24}$

O direito à liberdade sindical deve ser protegido em todas as suas manifestações, em especial pela ação estatal para impedir a disseminação de atos antissindicais. De outro modo, há que prevalecer o desempenho exemplar das organizações sindicais com o propósito de impulsionar a defesa das prerrogativas das ações sindicais, seja por intermédio da divulgação e

\footnotetext{
${ }^{22}$ ARAUJO, Adriane Reis de, op. cit., p. 39-40.

${ }^{23}$ Ibid., p. 41-42.

${ }^{24}$ VASCONCELOS FILHO, Oton de Albuquerque. Liberdades sindicais e atos anti-sindicais.

São Paulo: LTr, 2008. p. 72.
} 
internacionalização dos ataques ao aludido direito e, igualmente, pelas queixas ao Comitê de Liberdade Sindical da OIT. ${ }^{25}$

\subsubsection{Normatização internacional dos atos antissindicais}

No âmbito internacional, a proteção contra as violações do direito de liberdade sindical é respalda pelas Convenções n. 87 (Liberdade Sindical e Proteção ao Direito de Sindicalização), n. 98 (Direito de Sindicalização e de Negociação Coletiva), n. 135 (Proteção de Representantes de Trabalhadores) e n. 151 (Direito de Sindicalização e Relações de Trabalho na Administração Pública), cujos principais dispositivos foram apresentados no decorrer do trabalho.

Dentre as mencionadas Convenções, cumpre ressaltar o diploma n. 98, a qual apresenta caracteres dos atos antissindicais a partir de duas perspectivas jurídicas de variada origem, qual seja a tradição romano-germânica, quando faz uso da terminologia "discriminação" que advém do foro sindical, que consiste na proteção obreira voltada à liberdade sindical individual. A segunda tradição é a consutuedinária do common law, peculiarmente caracterizada pela interferência na livre organização sindical, atrela-se às práticas desleais ${ }^{26}$ e dizem respeito à liberdade sindical coletiva.

Ademais, sua temática versa de forma geral, principalmente para não interferir na sistemática do ordenamento jurídico de cada Estado, tal como pela possibilidade de abarcar o maior número de situações. Assim, a legislação nacional deve proteger a liberdade sindical além pactuação e da ruptura do vínculo de emprego, há de se considerar também o decurso do contrato de

\footnotetext{
${ }^{25}$ NICOLADELI, Sandro Lunard. A natureza jurídica da liberdade sindical e sua normatividade internacional. In: NICOLADELI, Sandro Lunard; PASSOS, André Franco de Oliveira; FRIEDRICH, Tatyana Scheila. $O$ direito coletivo, a liberdade sindical e as normas internacionais. São Paulo: LTr, 2013. v. I. p. 48.

${ }^{26}$ SILVA, Walküre Lopes Ribeiro da; LIMA, Firmino Alves, op. cit., p. 71-72.
} 
trabalho e os atos que possam acometê-lo, como a transferência e o rebaixamento do trabalhador. ${ }^{27}$

No que tange às discriminações antissindicais, conquanto tratem perfunctoriamente, não se pode olvidar das Convenções n. 111(Discriminação em Matéria de Emprego e Ocupação), n. 141 (Organizações de Trabalhadores Rurais), n. 154 (Fomento à Negociação Coletiva) e n. 158 (Término da Relação de Trabalho por Iniciativa do Empregador).

A Convenção n. 111 foi aprovada na $42^{\mathrm{a}}$ reunião da Conferência Internacional do Trabalho em 1958 e ratificada pelo Brasil em 26 de novembro de 1965. Apesar de não tratar diretamente da antissindicalidade, o diploma internacional considera que a discriminação viola os direitos previstos na Declaração Universal dos Direitos Humanos, a qual preceitua a liberdade sindical.

Ademais, conjuga a liberdade e a dignidade dispostas na Declaração de Filadélfia e se alinha com a Recomendação n. 111 da OIT, cuja alínea "f" do art. $2^{\circ}$ prevê o dever de todo Estado-membro formular uma política nacional que impeça a discriminação em emprego e ocupação, particularmente, em observância de "organizações de empregadores e de trabalhadores não deveriam praticar ou tolerar que se praticasse a discriminação com relação à admissão de associados, à manutenção da filiação ou à participação em suas atividades".

Quanto à Convenção n. 141, aprovada pela 60ª reunião da Conferência Internacional do Trabalho em 1975 e ratificada pelo ordenamento brasileiro em 27 de setembro de 1994; no preâmbulo, o texto convencional atenta para a importância das Convenções n. 11, 87 e 98, as quais são aplicáveis também aos trabalhadores rurais, especialmente no que tange à liberdade de constituir organizações livres e independentes. No item 2 do art. $3^{\circ}$, alerta para o respeito dos princípios de liberdade sindical, assim como pela proibição de ingerência, coerção ou repressão nas entidades sindicais rurais. Já no art. 5ㅜ, assevera que tais instituições não poderão sofrer discriminações de ordem legislativa ou administrativa.

${ }^{27}$ KAUFMANN, Marcus de Oliveira. A anti-sindicalidade e o anteprojeto de lei de relações sindicais.

Revista do Tribunal Superior do Trabalho, Brasília, vol. 71, n. 2, p. 188-229, maio/ago. 2005. p. 191. 
No que concerne à Convenção n. 154 , aprovada na $67^{a}$ reunião da Conferência Internacional do Trabalho em 1981 e ratificada em 10 de julho de 1992, visualiza-se a promoção de especial instrumento de efetivação da liberdade sindical, qual seja a negociação coletiva. Além disso, propugna-se a eminência das Convenções n. 87 e 98, bem como de outras recomendações da OIT. A redação do art. $2^{\circ}$ dita os fins do referido mecanismo, os quais se destacam: "a) fixar as condições de trabalho e emprego; ou b) regular as relações entre empregadores e trabalhadores; ou c) regular as relações entre os empregadores ou suas organizações e uma ou várias organizações de trabalhadores, ou alcançar todos estes objetivos de uma só vez".

Por fim, a Convenção n. 158 , aprovada na $68^{a}$ reunião da Conferência Internacional do Trabalho em 1982, ratificada em 05 de janeiro de 1995 e denunciada pelo Governo brasileiro em 20 de dezembro de 1996. No diploma, ressalta-se $o$ art. 5, o qual apresenta algumas circunstâncias que não constituem causa justificada para o fim da relação empregatícia pelo empregador, como "a) a filiação a um sindicato ou a participação em atividades sindicais fora das horas de trabalho ou, com o consentimento do empregador, durante as horas de trabalho" e "b) ser candidato a representante dos trabalhadores ou atuar ou ter atuado nessa qualidade".

\subsection{Sistema brasileiro de proteção contra atos e condutas antissindicais}

No que concerne à antissindicalidade no Brasil, cumpre aduzir sua propagação em quatro fases. A primeira fase denominada de "resistência" transcorreu do fim do regime escravocrata até 1934 e ambicionou o impedimento de movimentos revoltosos de trabalhadores, cujos óbices derivaram da ação legiferante propensa a "entorpecer e domesticar" as manifestações contrárias. Em seguida, a segunda etapa assinalada como de "controle", perdurou de 1934 a 
1945, na qual se observou o domínio estatal sobre as organizações sindicais, ainda que marcante a resistência dos organismos sindicais. ${ }^{28}$

De 1945 a 1988, sobreveio a fase centrada na "competição", período em que o movimento sindical teve seu comando disputado por várias correntes políticas. Ademais, o Estado ainda se manifestava por força da legislação corporativista. Na quarta fase, cuja marca é a "contemporização", a etapa inicia-se a partir da promulgação da Constituição Federal de 1988. A despeito da continuidade dos instrumentos de cunho controlador, como a unicidade e a contribuição compulsória, destacou-se a atuação estatal pela não ingerência nas entidades sindicais. ${ }^{29}$

O ordenamento jurídico brasileiro não dispõe de legislação específica contra atos e condutas antissindicais. O protecionismo decorre de dispositivos esparsos na Constituição Federal, nos Atos das Disposições Constitucionais Transitórias e da Consolidação das Leis do Trabalho, bem como do arcabouço de Precedentes do Tribunal Superior do Trabalho. Tais regramentos assemelham-se ao foro sindical expandido, uma vez que prevê, especialmente, a proteção dos dirigentes e representantes sindicais e, por consequência, os demais indivíduos na fruição dos direitos relacionados à liberdade sindical.

Primeiramente, identifica-se no art. $8^{\circ}$, I, da CF a impossibilidade de autorização para a constituição de organizações de trabalhadores ou empregadores, tal qual a proibição de quaisquer interferências do Poder Público. De acordo com Cláudio A. C. de Menezes ${ }^{30}$, "em suma, todo procedimento que vise à dominação, ao controle ou à interferência nas organizações obreiras é visto como indevido e ilícito." No inciso $V$ do mesmo dispositivo, encontra-se a proteção acerca da livre filiação e desfiliação, o qual deve ser combinado ao art. $543, \S 6^{\circ}$ da CLT, que proíbe a empresa de impedir o empregado de se associar a sindicato, organizar associação profissional ou sindical, bem como o exercício das atividades inerentes a qualquer ente sindicalizado, sob pena de ser punida.

A proteção à liberdade de fundação de sindicatos é contemplada na maioria dos ordenamentos latino-americanos e faz parte do denominado fuero

\footnotetext{
${ }^{28}$ MARTINEZ, Luciano, op. cit., p. 181-182.

29 lbid., p. 183-184.

${ }^{30}$ MENEZES, Claudio Armando Couce de, op. cit., p. 47.
} 
sindical (foro sindical), com destaque para a inamovibilidade dos fundadores enquanto perdurar as etapas fundacionais. O sistema protetivo concedido pelo foro sindical não é circunscrito exclusivamente aos dirigentes ou representantes sindicais. Na Colômbia, Paraguai, Peru e República Dominicana, por exemplo, há a salvaguarda dos negociadores de contratos coletivos e, no Brasil, dos membros da CIPA $^{31}$ (Comissão Interna de Prevenção de Acidentes). ${ }^{32}$ No que se refere ao cipeiro no Brasil, o art. 165 da CLT considera como arbitrária a dispensa não baseada em razões disciplinares, técnicas, econômicas ou financeiras, sob pena de reintegração do empregado dispensado.

Nesse contexto, 0 art. $8^{\circ}$, VIII da CF e o art. 543, $§ 3^{\circ}$ da CLT prevêem a garantia de emprego do diretor ou representante sindical ${ }^{33}$ durante 0 exercício da função de três anos e, complementarmente desde o registro da candidatura e um ano após o término do mandato. Nesses termos, a CLT garante por meio do art. 659, $\mathrm{X}$, no caso de propositura de reclamação trabalhista visando à reintegração do dirigente afastado, suspenso ou dispensado pelo empregador, a concessão de liminar até o resultado do mérito da demanda.

Segundo entendimento doutrinário, a garantia de emprego durante 0 exercício sindical não é medida suficiente para impedir a antissindicalidade, por isso, diversas legislações nacionais na América Latina, optam pelo elastecimento protetivo para antes e depois do mandato, uma vez que "han cesado em sus cargos de temer que la dirección de la empresa ceda a la tentación de 'arreglar cuentas' com los dirigentes o delgados que hayan mostrado más dinamismo o intransigencia”. ${ }^{34}$ Todavia, a súmula n. 369, II do TST limita a estabilidade

\footnotetext{
${ }^{31}$ Ato das disposições constitucionais transitórias. "Art. 10. [...] II - fica vedada a dispensa arbitrária ou sem justa causa: a) do empregado eleito para cargo de direção de comissões internas de prevenção de acidentes, desde o registro de sua candidatura até um ano após o final de seu mandato".

TST- Súm. n. 339. "[...] II - A estabilidade provisória do cipeiro não constitui vantagem pessoal, mas garantia para as atividades dos membros da CIPA, que somente tem razão de ser quando em atividade a empresa. Extinto o estabelecimento, não se verifica a despedida arbitrária, sendo impossível a reintegração e indevida a indenização do período estabilitário".

32 BRONSTEIN, op. cit., p. 95; 99.

${ }^{33}$ Precedente normativo n. 83 do TST: "Assegura-se a frequência livre dos dirigentes sindicais para participarem de assembléias e reuniões sindicais devidamente convocadas e comprovadas, sem ônus para o empregador".

${ }^{34}$ BRONSTEIN, op. cit., p. 102.
} 
provisória para apenas sete dirigentes sindicais e igualmente para o contingente de suplentes.

A limitação numérica dos sindicalistas contemplados pela garantia de emprego é veementemente defendida pela classe patronal, a qual sustenta tratar-se de um instrumento utilizado para beneficiar trabalhadores de pouca eficiência e indisciplinados. Por sua vez, os trabalhadores rechaçam tal colocação e explicam que a proteção para números reduzidos é insuficiente, pois os demais (sem garantia) permanecem sob o risco de represálias. Para tanto, propugna-se que a escolha do número dos sindicalistas protegidos não seja auferida com base na quantidade de membros pertencentes à entidade ou ao total de trabalhadores na empresa. ${ }^{35}$

A análise dos atos antissindicais a partir do empresariado tradicional demonstra o interesse da classe patronal pela manutenção da estrutura atual, a qual é mantida pelo apogeu do capital e do trabalho alheio como ferramenta para auferir lucratividade. Por isso, a atuação sindical capaz de alterar o cenário e constituir o mínimo de dignidade, por vezes, é posta em xeque pelos grupos econômicos. ${ }^{36}$

Ainda na seara constitucional, há de se mencionar o art. 11, segundo o qual se permite a eleição de representante dos trabalhadores nas empresas acima de duzentos empregados para intermediar o diálogo entre a classe patronal e de empregados. Entretanto, o representante eleito não usufrui da garantia de emprego assemelhada ao dirigente sindical, o que acarreta a pouca expressividade da representação nos locais de trabalho diante da iminência de retaliações de empregadores.

Mas, conforme acentua Alice Monteiro de Barros, o Brasil ratificou a Convenção n. 135 da OIT, que garante o emprego e autoriza a reintegração em decorrência de dispensa sem justa causa. A autora explica que há necessidade de regulamentação do prazo de "estabilidade" empregatícia transitória, da

\footnotetext{
${ }^{35}$ BRONSTEIN, op. cit., p. 100.

${ }^{36}$ VASCONCELOS FILHO, Oton de Albuquerque, op. cit., p. 87.
} 
extensão ao suplente e da imprescindibilidade de inquérito para apuração de falta grave, seja por meio ordinário ou pela normatização coletiva. ${ }^{37}$

Evidentemente, até que ocorra o disciplinamento legal sobre tais circunstâncias, os trabalhadores não poderão ser prejudicados. Assim, clamando pelo princípio protetivo, caberia a interpretação favorável e, consequentemente, a aplicabilidade analógica da garantia de emprego do dirigente ao representante local. Ademais, a ratificação de um documento internacional não autoriza a aplicabilidade somente dos dispositivos favoráveis aos interesses internos do país, por isso, o ato de ratificar é um chancela ao conteúdo disposto, sem mitigá-lo.

Acentua-se no diploma celetista, o art. $614, \S 2^{\circ}$, o qual versa sobre o dever dos sindicatos de afixarem ${ }^{38}$ em local visível da empresa, as cópias autênticas das convenções ou acordos coletivos firmados. Aparentemente, o descumprimento desse múnus não demonstra qualquer ato antissindical, porém, aqueles empregados não participantes do cotidiano sindical ficariam desinformados acerca das benesses acordadas entres as respectivas entidades e, em consequência, certos empregadores imbuídos de má-fé não lhes concederiam os direitos ajustados nos instrumentos coletivos.

No art. 544 da CLT, verifica-se exemplo expresso de prática discriminatória denominada preferencial shop, já que o dispositivo em comento estabelece preferência de contratação para os indivíduos sindicalizados. Contudo, o entendimento majoritário é pela não recepção do supracitado artigo pela Constituição Federal de 1988.

Realizadas as ponderações no ordenamento constitucional e trabalhista, é essencial a alusão à normatização penal a respeito do sistema protetivo antissindical. O Código Penal brasileiro é parco concernente à temática, tipifica no título IV os denominados "crimes contra a organização do trabalho", cujo art. 199 dispõe sobre o atentado à liberdade de associação, qual seja:

\footnotetext{
${ }^{37}$ BARROS, Alice Monteiro de. Representante dos empregados no local de trabalho. Revista do Tribunal Regional do Trabalho da 3a Região, Belo Horizonte, n. 58, p. 179-188, jan./dez. 1998 p. 188.

${ }^{38}$ Outrossim, cumpre observar: TST - Precedente normativo n. 104: Quadro de avisos (positivo). Defere-se a afixação, na empresa, de quadro de avisos do sindicato, para comunicados de interesse dos empregados, vedados os de conteúdo político-partidário ou ofensivo.
} 
Constranger alguém, mediante violência ou grave ameaça, a participar ou deixar de participar de determinado sindicato ou associação profissional:

Pena - detenção, de um mês a um ano, e multa, além da pena correspondente à violência.

A disposição legislativa penal mostra-se incompleta, visto que tutela apenas um aspecto da liberdade sindical. Além disso, protege a organização do trabalho contra condutas criminosas, enquanto as liberdades trabalhistas e de associação sindical ficam sem respaldo. Diante do cenário, observa-se a inadequação apresentada pelo legislador, seja pela ausência de tipo para as condutas antissindicais ou pela incongruência na tutela da organização do trabalho, aquém dos preceitos de um Estado Democrático de Direito. ${ }^{39}$

Ante as observações, constata-se que o ordenamento jurídico brasileiro não dispõe de um sistema de proteção contra atos e condutas antissindicais dotado de coercitividade e de efeitos sancionátorios. Evidentemente, tal existência poderia acarretar positivamente no desestímulo às violações do direito de liberdade sindical.

O legislador constitucional e infraconstitucional trata a proteção contra atos antissindicais com parcimônia. Desse modo, os atores sociais não são capazes de se munirem com recursos suficientes para impedir e punir exemplarmente as aludidas violações, o que reflete o elevado número de queixas perante o Comitê de Liberdade Sindical.

\subsubsection{Regramento do Anteprojeto de Lei de Relações Sindicais}

Diversamente do ordenamento contemporâneo, o Anteprojeto de Lei de Relações Sindicais destina capítulo específico formado por cinco artigos para prevenir e reprimir violações ao direito de liberdade sindical, segundo o qual, considera-se conduta antissindical "todo e qualquer ato do empregador que tenha por objetivo impedir ou limitar a liberdade ou a atividade sindical".

${ }^{39}$ SILVA, Walküre Lopes Ribeiro da; LIMA, Firmino Alves, op. cit., p. 81-82. 
A redação do projeto mostra-se inovadora ao se desvencilhar do "restrito método brasileiro de foro sindical", substituindo-o pelo tratamento sistemático das práticas antissindicais e de formas de combate. Nesse contexto, cita-se a proteção além dos dirigentes sindicais, o sistema protetivo poderá beneficiar indivíduos não sindicalizados, inclusive. Ademais, "se amolda aos costumes legais internacionais (principalmente à Convenção n. 98 da OIT) quando da previsão de um moderno sistema de combate", em especial por apresentar um rol ${ }^{40}$ não taxativo de práticas a serem combatidas. ${ }^{41}$

No art. 173 do Anteprojeto, conferem-se poderes ao magistrado trabalhista para determinar a interrupção do ato ilegítimo e a eliminação dos seus efeitos por parte do empregador violador da liberdade sindical (impedir ou limitar), assim como outras atividades inerentes ao seu exercício e ao direito de greve. $\mathrm{O}$ dispositivo não menciona o Estado como praticante de atos antissindicais, no entanto, o ente estatal também compõe a figura quando se reveste da figura de empregador e legislador.

Quanto aos legitimados à propositura da demanda, no art. 174 designa-se a organização com personalidade sindical (dentro do seu espaço de representação), bem como o trabalhador que sofreu a conduta prejudicial. Já no art. 176, concede-se ao juiz (mediante provocação) a faculdade de aplicar multa punitiva em decorrência da configuração de conduta antissindical, a qual deverá levar em consideração a três fatores: gravidade da infração, eventual reincidência e capacidade econômica do infrator. Ademais, a penalidade respeitará o valor de uma a quinhentas vezes o menor piso salarial no âmbito de

\footnotetext{
${ }^{40}$ O Anteprojeto de Lei de Relações Sindicais enumera as seguintes condutas: "Art. 175 [...] I subordinar a admissão ou a preservação do emprego à filiação ou não a uma entidade sindical; II - subordinar a admissão ou a preservação do emprego ao desligamento de uma entidade sindical; III - despedir ou discriminar trabalhador em razão de sua filiação a sindicato, participação em greve, atuação em entidade sindical ou em representação dos trabalhadores nos locais de trabalho; IV - conceder tratamento econômico de favorecimento com caráter discriminatório em virtude de filiação ou atividade sindical; $\mathrm{V}$ - interferir nas organizações sindicais de trabalhadores; VI - induzir o trabalhador a requerer sua exclusão de processo instaurado por entidade sindical em defesa de direito individual; VII - contratar, fora dos limites desta Lei, mão-de-obra com o objetivo de substituir trabalhadores em greve; VIII - contratar trabalhadores em quantidade ou por período superior ao que for razoável para garantir, durante a greve, a continuidade dos serviços mínimos nas atividades essenciais à comunidade ou destinados a evitar danos a pessoas ou prejuízo irreparável ao próprio patrimônio ou de terceiros; IX - constranger o trabalhador a comparecer ao trabalho com o objetivo de frustrar ou dificultar o exercício do direito de greve; X - violar o dever de boa-fé na negociação coletiva."

${ }^{41}$ KAUFMANN, Marcus de Oliveira, op. cit., p. 189; 204; 206.
} 
representação da organização sindical, independente do pagamento de multa coercitiva decorrente de obrigação de fazer ou não fazer.

No art. 177, destina-se tratamento isonômico para as entidades sindicais de trabalhadores que praticarem antissindicalidade. ${ }^{42}$ Trata-se da bilateralidade de combate aos atos antissindicais, pois demonstra que o status da entidade sindical de trabalhadores não se limita a ser sujeito passivo, ou seja, somente objeto de lesividade; outrossim, é visto como praticante de danos à liberdade sindical individual positiva e negativa, bem como à liberdade sindical coletiva ao atingir outras organizações. A bilateralização do projeto brasileiro é considerada excesso de zelo, visto que, frequentemente, o empregador é o autor da antissindicalidade, e não vítima. Na Argentina, por exemplo, o caráter bilateral foi sobreposto pela unilateralidade, tal qual pressupõe o arcabouço protetivo da legislação trabalhista latina. ${ }^{43}$

Antônio Rodrigues de Freitas Junior enfatiza a imperiosidade do estabelecimento de um regramento legal das condutas antissindicais e ressalta:

\begin{abstract}
Patenteia-se, por qualquer dos ângulos que se adote, a relevância e certa urgência no refinamento dos mecanismos jurídicos disponíveis, no Brasil, à coibição de condutas antissindicais. Até mesmo na remota hipótese de se lograr uma revisão no sistema jurídico brasileiro [...]. E assim para que o processo de acomodação à nova realidade não seja estigmatizado pela ingerência de empregadores inescrupulosos. ${ }^{44}$
\end{abstract}

Marcus de Oliveira Kaufmann explica que a defesa às práticas antissindicais não está adstrita à reformulação do sistema atual por meio do estabelecimento de um sindicalismo espontâneo e sem laços com o poder estatal ou da implementação do pluralismo sindical com observância da unidade. Complementarmente a isso, o ordenamento brasileiro não pode submeter-se a um "sistema de foro sindical, que precisa ser teleologicamente

\footnotetext{
${ }^{42}$ Segundo esse dispositivo, são cabíveis as providências judiciais visando a prevenção e reparação, as organizações obreiras que: "I - induzir o empregador a admitir ou dispensar alguém em razão de filiação ou não a uma entidade sindical; II - interferir nas organizações sindicais de empregadores; III - violar o dever de boa-fé na negociação coletiva; IV - deflagrar greve sem a prévia comunicação de que trata o art. 109 desta Lei".

${ }^{43}$ KAUFMANN, Marcus de Oliveira, op. cit., p. 209; 212.

${ }^{44}$ FREITAS JÚNIOR, Antônio Rodrigues de. Novas perspectivas para o direito coletivo do trabalho no Brasil(ou sobre a premência da disciplina legal da conduta antissindical). Revista do
}

Advogado, São Paulo, v.30, n.110, p.17-23, dez. 2010.p. 22-23. 
interpretado para se tornar amplo, com previsões pontuais não concatenadas e endereçadas, de forma dogmática e científica, diretamente ao combate" das violações de liberdade sindical. ${ }^{45}$

A despeito do caráter inovador do projeto, o verbete n. 818 do Comitê de Liberdade Sindical informa que as normas existentes nos ordenamentos domésticos, que proíbem a prática de atos antissindicais, são insuficientes caso não estejam acompanhas de procedimentos que assegurem a proteção eficazmente. Além disso, os meios de reparação devem ser rápidos, econômicos e totalmente imparciais. ${ }^{46}$

\subsection{Sistema protetivo contra atos e condutas antissindicais no direito comparado}

Diante da impossibilidade de cotejar inúmeros ordenamentos protetivos no direito comparado, optou-se pelo cotejamento do sistema italiano e espanhol em decorrência das contribuições legislativas e doutrinárias ao regramento brasileiro, bem como o modelo chileno, argentino e paraguaio devido à proximidade territorial e a inserção no Mercosul. Ademais, todos os países nominados ratificaram as Convenções n. 87 e 98 da OIT, normas internacionais fundamentais ao combate das práticas antissindicais.

A Lei italiana n. 300 de 20 de maio de 1970 dispõe sobre o Statuto dei lavoratori (Estatuto dos trabalhadores), cujo art. 28 apresenta o procedimento para a repressão do comportamento antissindical. O dispositivo mencionado estabelece que as associações sindicais nacionais poderão recorrer ao juiz local nos dois dias seguintes após o empregador praticar condutas que visem a impedir ou limitar o exercício da liberdade sindical e das atividades

\footnotetext{
${ }^{45}$ KAUFMANN, op. cit., p. 225.

${ }^{46}$ OIT. La libertad sindical. Recopilación de decisiones del Comité de Libertad Sindical del Consejo de Administración de la OIT. 5. ed. rev. Ginebra: Oficina Internacional del Trabajo, 2006. párrafos n. 820; 818. Nesse sentido observa-se o verbete n. 821: "Cuanto más se demora en completar un procedimiento, más difícil Le resulta al órgano competente fi jar una indemnización justa y adecuada, ya que la situación alegada ha cambiado a menudo de manera irreversible, el personal ha sido trasladada, etc., de suerte que resulta imposible ordenar una reparación adecuada o retornar a la situación anterior."
} 
correlacionadas, bem como o desrespeito ao direito de greve. Se o magistrado verificar a infração, ordenará ao empregador o imediato cessamento da conduta ilícita e a remoção dos seus efeitos.

No que tange ao interesse de agir dos sindicatos, majoritariamente há a interpretação de forma ampla, a qual contempla a defesa de trabalhadores não filiados ou aqueles ligados a outro sindicato. Ademais, entende-se que a ofensa antissindical dirigida a um trabalhador é extensiva ao interesse geral de liberdade sindical. ${ }^{47}$

Para obstar a atuação empresarial lesiva existem os instrumentos de resolução de conflitos baseados na autotutela, contudo, mostram-se ineficientes ante a força de algumas organizações sindicais. Por isso, o Estatuto dos Trabalhadores não se limitou na determinação de respeitar os direitos sindicais, o diploma impôs a respectiva sanção e a anulação das medidas indevidas de acordo com o procedimento específico. ${ }^{48}$

No art. 28, não há a apresentação detalhada e específica dos comportamentos antissindicais, o que favorece uma "noção de amplo espectro". Evidentemente, seria tarefa árdua a individualização de cada uma das possíveis condutas de discriminação, particularmente dos hábitos empresariais. ${ }^{49}$ Por outro lado, de acordo com Giancarlo Perone, a formulação normativa ampla comporta problemas interpretativos significativos referentes à definição do seu âmbito de aplicabilidade ou de individualização dos casos concretos atribuídos à conduta antissindical. Isso ocorre porque nem todos os comportamentos antagonistas podem ser qualificados juridicamente sob o enfoque violador. Sendo assim, é preciso individualizar um critério discriminatório entre os comportamentos meramente antagônicos daqueles ilegítimos. ${ }^{50}$

O procedimento do Estatuto é divido em: a) especialidade das regras processuais; b) atuação do sindicato; c) instrumento sancionatório particular; d) uso de técnica normativa particular para a identificação do caso juridicamente relevante. No que diz respeito à especialidade, incute na aplicação de

\footnotetext{
${ }^{47}$ LEVI, Alberto. A repressão da conduta anti-sindical na Itália. In: FREDIANI, Yone; ZAINAGHI, Domingos Sávio (Coord.). Relações de direito coletivo brasil-itália. São Paulo: LTr, 2004. p. 197.

${ }^{48}$ GIUGNI, Gino, op. cit., p. 87.

49 LEVI, Alberto. op. cit., p. 193.

${ }^{50}$ PERONE, Giancarlo. Lo statuto dei lavoratori. Torino: Utet, 1997. p. 160.
} 
regramento diferenciado para acelerar a tutela jurisdicional, visto que a tempestividade é fundamental nas ocorrências sindicais. Quanto à participação da organização sindical, reflete a dimensão coletiva dos conflitos industriais. Por fim, os efeitos sancionatórios correspondem a uma espécie de coação indireta, a qual obriga o violador a cumprir as determinações do magistrado, sob pena de prisão ou pagamento de indenização, por exemplo. ${ }^{51}$

Consoante a doutrina e a jurisprudência itálica, para a aplicabilidade do procedimento disposto no referido artigo (28), a conduta antissindical deverá ser atual ou com efeitos atuais, isto é, não comporta atos predecessores. ${ }^{52}$

O legislador cercou-se por normas teleológicas, pois caracterizam "o comportamento ilegítimo baseado em sua potencialidade para lesar os bens protegidos e não em características estruturais". Desse modo, insere-se em um universo de maior amplitude, já que possibilita o tratamento de diversas situações. Ademais, o comportamento antissindical é de natureza "pluriofensiva", pois a norma destinada a reparar ou prevenir a conduta pode ser aplica em âmbito coletivo e individual. Isso significa que o trabalhador poderá requerer a defesa dos seus interesses e de maneira concomitante, o sindicato atuará sobre o mesmo ato. Em tal hipótese, há a violação da liberdade sindical do indivíduo e do grupo ao qual pertence. ${ }^{53}$

Essa pluriofensividade se dá, por exemplo, no afastamento do dirigente de representação sindical empresarial, distanciamento que incidirá simultaneamente na entidade sindical e no trabalhador individual. ${ }^{54}$

A relevância do art. 28 não se exaure somente no fato de ter introduzido no sistema italiano de relações laborais, um modo de tutela jurisdicional dos direitos e da liberdade sindical, mas também por ter elaborado um procedimento com características próprias, concebido para reprimir de forma eficaz a atividade antissindical. ${ }^{55}$

${ }^{51}$ GIUGNI, Gino, op. cit. 89.

52 LEVI, Alberto, op. cit., p. 194.

${ }^{53}$ GIUGNI, Gino, op. cit., p. 89-90.

${ }_{54}^{54}$ LEVI, Alberto, op. cit., p. 194.

${ }^{55}$ COLLA, Filippo; ROTONDI, Francesco. II comportamento antisindacale. (aspetti sostanziali e processuali). Milani: CEDAM, 2004. p. 56. 
$\mathrm{Na}$ Espanha $^{56}$, a repressão às violações de liberdade sindical é amparada pela combinação do art. 15 da Lei Orgânica de Liberdade Sindical (LOLS) com o art. 315 do Código Penal (CP). ${ }^{57}$ De acordo com tal normatização, a decisão que reconhece a conduta antissindical determinará o seu imediato cessamento, assim como a reparação pelos danos sofridos e o encaminhamento ao Ministério Público para apuração de possíveis delitos. Ademais, a condenação pode variar com a prisão de seis meses a três anos e multa. ${ }^{58}$

A LOLS articula-se em torno de dois núcleos básicos, quais sejam: a) a introdução de procedimentos jurisdicionais especiais e o aparato sancionatório peculiar; b) a caracterização do conjunto de condutas disfuncionais cuja repressão se persegue por meio dos citados mecanismos. No que diz respeito aos aspectos processuais, cita-se os instrumentos protetivos anteriores à edição da referida legislação, cuja rigidez não supria as diversas formas que podem adquirir as práticas antissindicais. ${ }^{59}$

A prática antissindical consiste em um crime comum, cujo bem jurídico protegido é a liberdade sindical. Os principais autores são os empregadores, 0 sindicato patronal, os entes da administração pública, a associação pública ou privada, assim como qualquer pessoa. No setor privado, geralmente o praticante do ato é o empresário em razão da oposição de interesses com relação aos trabalhadores. Quanto às condutas praticadas no âmbito público, externam-se pela proibição de atividades sindicais, concessão de privilégios a certas entidades

\footnotetext{
${ }^{56}$ A partir da articulação dos artigos 13 e 15 da LOLS é possível extrair o seguinte conceito de conduta antissindical: "[...] son caracterizadas como lesiones de la libertad sindical o comportamientos lesivos de los derechos de libertad sindical, pues el rasgo a través del que el legislador há decidido identificarlas es el de su idoneidad para lesionar o violar los derechos tutelados. In: RAYMOND, Wilfredo Sanguineti. Lesion de la libertad sindical y comportamientos antisindicales. Estúdio de la estructura y el contenido del juicio de antisindicalidad. Madrid: Ministerio de Trabajo y Seguridade Social, 1993. p. 29.

${ }^{57}$ LOLS: art. 15 - "Si el órgano judicial entendiese probada la violación del derecho de libertad sindical decretará el cese inmediato del comportamiento antisindical, así como la reparación consiguiente de sus consecuencias ilícitas, remitiendo las actuaciones al Ministerio Fiscal, a los efectos de depuración de eventuales conductas delictivas."

CP: art. 315 - "1. Serán castigados con las penas de prisión de seis meses a tres años y multa de seis a doce meses los que mediante engaño o abuso de situación de necesidad, impidieren o limitaren el ejercicio de la libertad sindical o el derecho de huelga. 2. Si las conductas reseñadas en el apartado anterior se llevaren a cabo con fuerza, violencia o intimidación se impondrán las penas superiores en grado. 3. Las mismas penas del apartado segundo se impondrán a los que, actuando en grupo, o individualmente pero de acuerdo con otros, coaccionen a otras personas a iniciar o continuar una huelga."

${ }^{58}$ BAYLOS, Antonio; TERRADILLOS, Juan. Derecho penal del trabajo. Madrid: Trotta, 1997. p. 142.

${ }^{59}$ RAYMOND, Wilfredo Sanguineti. Op. cit., 20;24.
} 
em detrimento a outras e atos prejudiciais ao exercício do direito de greve. Os sujeitos passivos da violação podem ser todos, exceto os membros das Forças Armadas, os Institutos Armados de caráter militar e os magistrados. ${ }^{60}$

No Chile, o regramento sindical fica a cargo do Código del Trabajo em sete artigos do capítulo $X$, os quais prevêem a antissindicalidade e impõem sanções. Em tal diploma destaca-se o art. 289, cujos principais atos praticados pelo empregador atentatórios à liberdade sindical incorrem na tentativa de obstruir a formação ou funcionamento das organizações sindicais de trabalhadores, bem como a negativa injustificada de receber seus dirigentes, efetuar pressões por meio de ameaças de perda de emprego ou benefícios e o fechamento da empresa caso acordem a fundação de um sindicato.

O referido dispositivo também elenca: a negativa de informações pertinentes aos dirigentes; a oferta ou outorga de benefícios especiais com o fim exclusivo de desestimular a criação de sindicatos; ações que incentivem a não filiação a entidades já formadas; a prática de atos de ingerência sindical; a execução de discriminações entre trabalhadores com o objetivo de incentivar ou desestimular a filiação ou desfiliação.

Ademais, o art. 290 apresenta as práticas desleais do trabalhador, das organizações sindicais e do empregador no que se refere aos atos contrários à liberdade sindical, as quais se destacam: o acordo com o empregador para a execução das práticas desleais atentatórias previstas no art. 289 ou corrigir o empregador a executar tais atos; a combinação com o empregador para dispensar trabalhadores ou outra medida discriminatória por não ter efetuado o pagamento de multas ou dívidas a um sindicato.

Na Argentina, a antissindicalidade é disciplinada pela Ley n. 23.551 de 1988 (Asociaciones Sindicales), a qual dedica três artigos ao denominado sistema das práticas desleais. $\mathrm{O}$ art. 53 elenca como autores da deslealdade os empregadores e as organizações sindicais que os representam, os quais não podem, por exemplo: subvencionar direta ou indiretamente as organizações sindicais de empregados; intervir na constituição, funcionamento ou administração das entidades; obstruir ou dificultar a filiação dos trabalhadores;

${ }^{60}$ BAYLOS, Antonio; TERRADILLOS, Juan. op. cit., 149-150. 
promover ou patrocinar a filiação dos trabalhadores em determinada associação sindical; adotar represálias contra os trabalhadores que participem das atividades sindicais ou de terem acusado, testemunhado em procedimentos vinculados às práticas desleais.

No art. 55, há como forma de sanção o pagamento de multas, e quando a prática derivar das organizações patronais a penalidade será calculada pelo juiz até o limite de $20 \%$ das receitas auferidas a partir das contribuições pagas pelos membros no mês de ocorrência da infração.

No Paraguai, a Lei n. 213 de 1993 estabelece o Código del Trabajo e apresenta um sistema protetivo baseado no fuero sindical. De acordo com o art. 318, usufruem de estabilidade sindical: a) onze membros titulares do conselho de cada sindicato, identificados durante a eleição e se houver mais de um sindicato de empresa, o mais representativo terá assegurada a proteção de sete dirigentes; delegados do sindicato representativo; até três dirigentes sindicais ou organizadores; até 4 negociadores de contrato coletivo e regulamento interno; e os diretores dos sindicatos, federações e confederações.

Ressalta-se o rápido procedimento de reintegração do dirigente afastado, segundo o art. 320, o magistrado determinará o retorno às funções no prazo de quarenta e oito horas, bem como o restabelecimento das condições modificadas. Assim, o afastamento do trabalhador estável ocorrerá somente em decorrência da existência de justa causa.

Verifica-se que o modelo paraguaio é o que mais se aproxima da realidade brasileira ao disciplinar o foro sindical, entretanto, a sistemática italiana relaciona-se à disposição do Anteprojeto de Lei de Relações Sindicais que depende da aprovação da PEC n. 369/2005.

\subsection{Comitê de Liberdade Sindical e análise de queixas}

Em 1951, logo após a adoção das Convenções n. 87 e 98, o Conselho de Administração da OIT instituiu o Comitê de Liberdade Sindical (CLS). Trata-se de uma comissão tripartite permanente, formada por 
representantes dos governos, empregadores e trabalhadores, cujo objetivo primordial é a análise das queixas ${ }^{61}$ advindas de entidades sindicais patronais ou de trabalhadores acerca das violações de liberdade sindical.

Inicialmente, a base para a investigação das reclamações sobre 0 desrespeito ao dito princípio limitava-se aos artigos 24 a 34 da Constituição da OIT. Entretanto, tais dispositivos não contemplavam a possibilidade de análise de casos em que determinado Estado membro não tivesse ratificado qualquer das mencionadas Convenções, assim:

\begin{abstract}
Art. 24. Toda reclamação, dirigida à Repartição Internacional do Trabalho, por uma organização profissional de empregados ou de empregadores, e segundo a qual um dos Estados-Membros não tenha assegurado satisfatoriamente a execução de uma convenção a que o dito Estado haja aderido, poderá ser transmitida pelo Conselho de Administração ao Governo em questão e este poderá ser convidado a fazer, sobre a matéria, a declaração que julgar conveniente.
\end{abstract}

Diante da celeuma, criou-se um instrumento com efetividade plena com a finalidade de proteger "verdaderamente la libertad sindical y su aplicación en la práctica, era necesario crear un mecanismo adicional que abarcase también las situaciones respecto de las cuales los convenios pertinentes no han sido ratificados". 62

Desse modo, originou o Comitê de Liberdade Sindical, defensor do direito de negociar conectado à liberdade sindical, assim como uma negociação coletiva subordinada ao respeito da boa fé e confiança entre as partes negociantes para alcançar o êxito. ${ }^{63}$

Consoante o verbete n. 2 do CLS, a criação do referido órgão internacional tem o condão de melhorar as condições de trabalho e promover a liberdade sindical nos Estados. Por isso, a temática tratada pela OIT nesse sentido não interfere na autonomia dos países ou significa qualquer intervenção

\footnotetext{
${ }^{61}$ Consoante Arnaldo Süssekind, "a expressão 'queixa' empregada no ato instituidor do Comitê tem sentido genérico e alcança os procedimentos previstos nos arts. 24 a 34 da Constituição. A quase totalidade dos casos resulta de reclamações oferecidas por organizações sindicais de trabalhadores". In: SÜSSEKIND, Arnaldo. Direito internacional do trabalho. 3.ed. São Paulo: LTr, 2000. p. 275.

${ }^{62}$ OIT. El Comité de Libertad Sindical: impacto desde su creación. Oficina Internacional del Trabajo: Ginebra, 2001. p. 08.

${ }^{63}$ NASCIMENTO, Amauri Mascaro. Compêndio de direito sindical. 7.ed. São Paulo: LTr, 2012. p. 100.
} 
nos assuntos internos, pois essa atuação está de acordo com os limites da chancela advinda dos seus membros. ${ }^{64}$

A Comissão reúne-se três vezes ao ano e, geralmente, os casos submetidos são acompanhados de provas documentais. No entanto, frequentemente, representantes da OIT dirigem-se aos países em busca de informações adicionais acerca dos elementos componentes da queixa, bem como para dialogar diretamente com os Estados e demais partes interessadas. Há que se destacar também as missões tripartites formadas por integrantes das três categorias supramencionadas. ${ }^{65}$

Quanto aos efeitos produzidos pela análise realizada, o Comitê visa à garantia e a promoção do direito de associação de trabalhadores e empregadores. Sendo assim, sua função precípua não acarreta a acusação de governos ou a condenação. Desse modo, o Comitê pode ser caracterizado pelo:

\footnotetext{
[...] el carácter constructivo y no represivo del proceder del Comité de Libertad Sindical, que presta asesoramiento a los Estados que tratan de poner su legislación nacional en armonía con los principios en materia de libertad sindical. Dado que la delimitación de su competencia es de su exclusiva incumbencia, las críticas referentes a una motivación política subyacente han sido dejadas de lado y así, poco a poco, se elevó al Comité al rango de mecanismo que podríamos denominar cuasijudicial. ${ }^{66}$
}

A despeito do alvitre educativo das decisões do Comitê, não há que se falar em soberania da legislação nacional, pois a comissão possui faculdade, por exemplo, para estabelecer se uma organização será considerada de caráter profissional, consoante os preceitos da Constituição da OIT ou receber reclamações de entidades consideradas dissolvidas, clandestinas ou exiladas. ${ }^{67}$

De acordo com Arnaldo Süssekind, há natureza de sanção moral nas conclusões e recomendações do Comitê aprovadas pelo Conselho de

\footnotetext{
${ }^{64}$ OIT. La libertad sindical. Recopilación de decisiones del Comité de Libertad Sindical del Consejo de Administración de la OIT. 5. ed. rev. Ginebra: Oficina Internacional del Trabajo, 2006. párrafo n. 2, p. 7.

65 Ibid., p. 11,16 e 17.

${ }^{66} \mathrm{lbid} .$, p. 13-14.

${ }^{67}$ Ibid., p. 13.
} 
Administração, visto que fazem parte do Boletim Oficial da Repartição Internacional do Trabalho e de massiva divulgação na imprensa mundial. ${ }^{68}$

Ultimamente, constatou-se diminuição considerável junto ao Comitê de Liberdade Sindical da OIT das queixas relacionadas à suspensão e dissolução das entidades sindicais. Por outro lado, observa-se o quão sutis tornaram-se as perseguições antissindicais, uma vez que tais ações "sofisticaram-se, escondendo-se, agora, sob 0 manto da respeitabilidade jurídica". Nesse contexto, habitualmente, são verificados atos praticados pelo empregador em face de sindicalistas (individualmente) e em desfavor das organizações de trabalhadores, tal como práticas comissivas e omissivas emanadas de autoridades públicas em prejuízo dos agrupamentos. ${ }^{69}$

Certas práticas antissindicais, frequentemente são constadas em maior número, o que permite a divisão em blocos. No primeiro grupo, o empregador é o agente antissindical e os sindicalistas, em âmbito individual, as vítimas. Tais ações ocorrem de forma preventiva, quando intentam obstaculizar a constituição de organizações sindicais, impedem a filiação a sindicatos já existentes ou interferem na designação das autoridades sindicais. De outro modo, existe a forma repressiva, cujos atos são manifestados por meio de represálias ao exercício sindical dos trabalhadores. ${ }^{70}$

No segundo grupo, reúnem-se as técnicas patronais contra a o sindicato (ser coletivo), comumente conexas ao reconhecimento do sindicato. Nos países latinos americanos, de maneira contumaz, constata-se o fomento aos "sindicatos amarillos" (sindicatos amarelos), assim como a outras associações obreiras sob dependência econômica do setor empresarial. Nesse sentido, o CLS (1993) menciona as associações solidárias da Costa Rica. ${ }^{71}$

O terceiro grupo é formado por ações ou omissões das autoridades visando o declínio das organizações sindicais. Constata-se, expressa ou tacitamente, a negativa de concessão do registro ou da personalidade jurídica dos sindicatos. Outrossim, há a ingerência estatal na constituição e funcionamento das entidades, particularmente pelo regramento doméstico

\footnotetext{
${ }^{68}$ SÜSSEKIND, Arnaldo (200), op. cit., p. 279.

${ }^{69}$ VASCONCELOS FILHO, op. cit., p. 79.

${ }^{70}$ BRONSTEIN, op. cit., p. 89.

${ }^{71}$ lbid., p. 89.
} 
exagerado no cotidiano sindical. Nesse contexto, cita-se o conluio entre autoridades públicas e o patronato para a procrastinação do registro sindical, enquanto o empregador dispensa ou empreende represálias àqueles que desejam sindicalizar-se. Trata-se de evidente afronta à liberdade sindical individual de constituir entidades representativas da classe trabalhadora, especialmente na modalidade de sindicato de empresa. ${ }^{72}$

Após a apresentação das principais características do CLS, faz-se imprescindível realizar um estudo de $\operatorname{casos}^{73}$ contemplando as violações de liberdade sindical. Para tanto, analisou-se reclamações originadas de ordenamentos onde prevalece a unicidade sindical, a pluralidade sindical e a unidade espontânea. Ressalta-se que no caso do monisto a pesquisa centralizouse apenas no ordenamento brasileiro, tendo em vista o desenvolvimento da temática do trabalho. Outrossim, considerou-se países que ratificaram os principais instrumentos de combate aos atos antissindicais aprovados pela Organização Internacional do Trabalho.

\subsubsection{Queixas contra o Brasil}

O Brasil possui catalogado perante o CLS dois casos em andamento e sessenta e quatro encerrados. Na pesquisa, optou-se por reclamações que envolvessem a figura do empregador sob o aspecto público e privado.

Primeiramente, analisou-se o Caso n. 2.470, apresentado em $1^{\circ} \mathrm{de}$ dezembro de 2005, cujos querelantes são a Central Única dos Trabalhadores e o Sindicato dos Químicos Unificados (Regional de Vinhedo) em face da empresa IGL Industrial Ltda pertencente ao grupo econômico Unilever.

\footnotetext{
${ }^{72}$ BRONSTEIN, op. cit., p. 89-90; 94; 96-97. Para o autor, "[...] la constituición de um sindicato de industria se hace normalmente fuera del lugar de trabajo y pasa más desapercibida para el empleador que la de um sindicato de empresa. [...] el empleador tiende a resistir mucho más la creación de um sindicato de empresa que uno de industria, al que percibe como una amenaza más lejana al ejercicio de su autoridad."

${ }^{73}$ As informações acerca das queixas envolvendo as organizações sindicais e os Governos estrangeiros foram coletadas no sítio eletrônico da Organização Internacional do Trabalho até a data de 31 ago. 2014. Disponível em: <http://www.ilo.org/global/lang--es/index.htm>.
} 
De acordo com os reclamantes, a referida entidade sindical representa $59,70 \%$ dos trabalhadores da empresa. Nas últimas décadas, alegaram que o empregador utilizou práticas autoritárias e não favoreceu o diálogo social, tendo em vista os diversos conflitos com o sindicato. Tal como ocorreu em 2001, durante paralisação da linha produtiva em prol de reivindicações por melhores salários, renovação de contratos coletivos, assim como pela dispensa em massa efetuada em anos anteriores.

Diante das manifestações, a querelada insurgiu-se por meio de ameaças telefônicas aos trabalhadores e de filmagens para identificar os empregados participantes e thes pressionarem. Ademais, recorreu à infiltração de líderes nas assembleias dos trabalhadores e negou o livre acesso dos dirigentes sindicais ao ambiente laboral ou permitiu com o acompanhamento de seguranças.

Outrossim, aduziram que a empresa constituiu uma forma própria de representação dos empregados no local de trabalho (Grupo de Trabalho para a Melhoria do Ambiente), paralela ao sindicato (semelhante ao sindicato de empresa), " $y$ dócil ante sus deseos e imposiciones". Além disso, informaram que a Unilever não reconheceu o Comitê Sindical Nacional da Unilever Brasil, formado pelos sindicatos representativos de todas as unidades empresariais espalhadas pelo território nacional.

Por fim, os querelantes citaram a campanha patronal para incentivar a desfiliação sindical dos seus empregados a partir da distribuição de formulários e a disposição de linha telefônica gratuita, inclusive com a possibilidade de solicitar a desfiliação.

Ante a exposição dos fatos, os denunciantes solicitaram ao CLS recomendação do governo brasileiro para que garantisse: a manifestação sindical de forma livre, no interior e exterior da empresa; liberdade de filiação; liberdade de realização de piquetes pacíficos sem ingerência patronal; abstenção de práticas incentivadoras da desfiliação, reconhecimento do referido Comitê; e a abstenção de filmar as manifestações e assembleias de trabalhadores sem o consentimento individual. 
Em reposta, o governo brasileiro argumentou que o Ministério do Trabalho e Emprego enviou auditor fiscal do trabalho a fim de realizar entrevistas com as partes para a apuração das circunstâncias.

No que diz respeito às observações formuladas pela Unilever e transmitidas pelo governo brasileiro, cumpre destacar que a empresa rechaçou taxativamente as acusações da queixa e afirmou que sempre atuou no sentido de proteger a integridade física dos seus trabalhadores e respeitou o livre direito de manifestação sindical, até mesmo quando exercido de forma violenta e agressiva. Quanto à alegação de realizar campanha de desfiliação, arguiu que o sindicato distorceu os fatos, porque desde janeiro de 2005 colocou à disposição de todos os trabalhadores das unidades da América Latina, linha telefônica gratuita (0800) para a solicitação de serviços e realização de consultas por meio de ofício prestado por empresa subcontratada sob orientação da Unilever.

Entretanto, afirmou que houve elevado contingente de pedidos do procedimento de desfiliação sindical, o que repercutiu na suspensão de contribuições sindicais mensais, por isso "um funcionário da empresa subcontratada, por sua própria iniciativa e de boa fé, mas em dissonância com a direção da Unilever, decidiu produzir um formulário de orientação e colocou-o no quadro de avisos, a fim de facilitar o seu trabalho".

No que concerne à criação do aludido grupo de trabalho, destacou a intenção de sempre manter canais permanentes de comunicação com os trabalhadores, os quais possibilitam aos empregados manifestarem livremente suas opiniões, reivindicações, esclarecimentos de dúvidas e o oferecimento de sugestões; contudo, sem a finalidade de substituir ou inibir a atuação sindical. Em relação ao reconhecimento do citado Comitê Sindical Nacional, sustentou que apenas a minoria dos sindicatos desejou a representação por essa via, a maioria analisou a situação como uma ameaça à organização.

O CLS lembrou nas suas conclusões iniciais de que as alegações da queixa referem-se às práticas antissindicais e considerou preocupante que o governo brasileiro apenas transmitiu as informações das partes sem ter emitido qualquer juízo a respeito. Ademais, o órgão da OIT observou contradição nas afirmações dos querelantes e da empresa, bem como lamentou a resposta 
brasileira acerca da ausência de observações específicas sobre os fatos alegados.

O CLS classificou a distribuição de formulários e a disponibilização de linha telefônica para desfiliação sindical, como práticas de ingerência nos assuntos internos do sindicato. Para tanto, recordou o art. $2^{\circ}$ da Convenção n. 98 , o qual preceitua a necessidade de proteção contra os referidos atos.

Por fim, o CLS recomendou que: 1) o governo brasileiro realizasse investigação acerca das práticas antissindicais alegadas; 2) o acompanhamento dos dirigentes sindicais por seguranças em dadas oportunidades parece medida necessária, mas não deve interferir nos assuntos sindicais e nem na comunicação com os trabalhadores; 3 ) quanto ao grupo de trabalho, o governo fiscalizasse para que não seja usado em detrimento do sindicato; 4) lamentou o governo não ter enviado informações sobre o reconhecimento do Comitê Sindical Nacional pela empresa e solicitou que realizasse investigação sobre os fatos alegados; e 5) quanto à distribuição de formulários e colocação de linha telefônica gratuita, pediu ao governo brasileiro que corrigisse rapidamente os efeitos desse tipo de ingerência e, inclusive, impusesse sanções dissuasivas contra o empregador para evitar incidentes semelhantes futuramente.

Posteriormente às cobranças, o Governo brasileiro apresentou 0 empreendimento das seguintes ações: 1) o trabalho investigativo do Ministério Público do Trabalho (MPT) em relação aos direitos, tal como o papel do Juízo trabalhista que condenou a empresa em abster-se da prática de ações que possam influenciar a filiação ou desfiliação a um sindicato profissional ou nas atividades sindicais; 2) a Procuradoria Regional do Trabalho comprovou as irregularidades após a oitiva dos representantes sindicais e da empresa; 3) fixação de multa ante o descumprimento das obrigações de não cometer atos antissindicais detalhados na sentença; 4) homologação de acordo entre o Ministério Público do Trabalho e a Unilever, o qual reafirma os princípios de liberdade sindical e negociação coletiva.

Diante dos fatos apresentados, o CLS lamentou a constatação judicial dos atos antissindicais e destacou as medidas corretivas. Além disso, solicitou ao Governo que vigie o cumprimento dos princípios de liberdade sindical na Unilever e enviasse consideração acerca da negativa de reconhecimento do Comitê 
Sindical Nacional. Em 30 de março de 2009, a CUT e o sindicato profissional enviaram comunicado informando o descumprimento por parte da empresa do acordo firmado junto ao MPT e a realização de novos atos antissindicais, como a perseguição de dirigente sindical, o não reconhecimento do mencionado Comitê, a restrição ao exercício das licenças sindicais dos dirigentes e a dificuldade para a emissão da documentação dos acidentes de trabalho.

O CLS analisou o caso pela última vez após o envio de informe da Unilever, segundo o qual a empresa esclareceu que não reconheceu a existência do Comitê Sindical Nacional devido à estrutura sindical brasileira, que não prevê a comissão de empregados por empresa. Ademais, o Sindicato dos Químicos Unificado representa apenas 3\% de todos os seus empregados e, de outro modo, a Unilever mantém o diálogo e canais de comunicação com toda representação legítima de trabalhadores.

Em relação às novas práticas antissindicais a empresa: 1) declarou que o dirigente foi dispensado por baixa produtividade, bem como não gozava de estabilidade, inclusive o sindicato havia suspendido-o das suas funções até o final do mandato; 2) ressaltou a existência de 25 dirigentes sindicais, dos quais $70 \%$ usufruem de licença remunerada e aqueles que não a tem podem ausentar-se do trabalho para as atividades sindicais; 3) informou a documentação da totalidade de acidentes de trabalho e investiu $\mathrm{R} \$ 3.5$ milhões de reais em 2009 nas áreas de saúde e segurança no trabalho, cujos índices acidentários são de 10 sinistros por ano em uma totalidade de 12.300 trabalhadores. Diante de tais informações, o CLS "toma nota con interés de estas últimas informaciones".

Posteriormente, examinou-se o Caso n. 2.795, cuja queixa foi apresentada ao CLS em 15 de junho de 2010, pela União Geral dos Trabalhadores (UGT) em razão de inegociabilidade do Tribunal de Justiça de São Paulo (TJSP) e de autoridades competentes.

Segundo a reclamante, por diversas ocasiões o Sindicato União dos Servidores do Poder Judiciário do Estado de São Paulo (SUSPJESP) formulou, sem sucesso, reivindicações acerca de recomposição salarial perante o referido órgão judiciário e o Governo do estado de São Paulo. Diante das circunstâncias, não restou alternativa a não ser a realização de uma greve com o intuito de 
sensibilizar o atendimento fixado na Lei n. 12.177/2004, que estabelece a data de $1^{\circ}$ de março de cada ano para deliberar sobre tais questões financeiras.

Ainda de acordo com a UGT, o sindicato profissional interpôs dissídio coletivo de greve perante Órgão Especial do TJSP, cuja autoridade judicial violou decisões do CLS, quais sejam: 1) determinou o desconto salarial dos servidores grevistas pelos dias de ausência, sem a possibilidade de compensação; 2) sustentou a proibição do exercício do direito de greve por servidores que desempenham atividades relacionadas à manutenção da ordem e da segurança pública, assim como da administração da justiça e dos integrantes das carreiras de Estado; e 3) estabeleceu que o sindicato se abstivesse de promover a paralisação, seja total ou parcial, das atividades dos seus representados a partir da notificação, sob o risco de pagamento de multa diária, bem como a cominação ao sindicato e aos dirigentes (solidariamente) que não iniciassem outras greves até o julgamento definitivo da demanda.

O CLS lamentou a ausência de resposta às alegações da querelante por parte do Governo brasileiro. Também lembrou que o objetivo de todo exame das denúncias relativas às violações de liberdade sindical é promover o respeito aos direitos sindicais de direito e de fato. Nesse sentido, se o procedimento protege os governos contra acusações infundadas, tais entes devem reconhecer a importância do fornecimento de respostas detalhadas e precisas acerca do alegado. Para tanto, esperava que o Governo brasileiro se mostrasse mais cooperativo futuramente.

Ademais, quanto à negativa de negociação coletiva, o CLS recorda a ratificação da Convenção n. 151 (Direito de Sindicalização e Relações de Trabalho na Administração Pública), a qual se aplica às instituições públicas. Por isso, o órgão insistiu para que o Governo tomasse todas as medidas cabíveis com o intuito de fomentar as negociações entre o SUSPJESP e as autoridades competentes.

No tocante à decisão que autorizou os descontos salariais e a proibição de novas greves, o CLS enfatizou por meio do verbete n. 654 que a dedução salarial dos dias de greve não coloca objeções aos princípios de liberdade sindical. Além disso, entendeu que a impossibilidade de novas medidas de força até o julgamento final da demanda, também não contrariam o aludido direito. Por 
isso, resolveu pelo não prosseguimento de análise das alegações. Por fim, a título de recomendação, insistiu para que o Governo brasileiro fomentasse a negociação coletiva entre as partes e que atendidas às particularidades da Convenção n. 154 (Incentivo à Negociação Coletiva), os servidores públicos pudessem exercer o direito de negociação coletiva.

Em 5 de junho de 2012, o Governo brasileiro enviou comunicado ao CLS, no qual informou as ações implementadas, quais sejam: 1) o Ministério do Trabalho e Emprego constituiu o Conselho de Relações de Trabalho - CRT (consiste em fórum de composição tripartite, cujo objetivo é promover a democratização das relações de trabalho, bem como o entendimento entre trabalhadores, empregadores e o Governo Federal); 2) o CRT fomenta a negociação coletiva e orienta o Ministério do Trabalho e Emprego; 3) o CRT formou três câmaras de formação dúplice (servidores públicos, Governo empregadores, Governo - servidores públicos); 4) realização de reuniões do Governo com servidores.

Diante de tais circunstâncias, o CLS elogiou a constituição do Fórum, o fomento à negociação coletiva e o diálogo social. A Comissão também expressou a esperança de que as partes possam considerar as modalidades de aplicação da Convenção n. 154 da OIT.

A partir dos casos expostos, inicialmente, restou evidente a inércia do Governo brasileiro em ambas as situações. As providências necessárias foram adotadas somente depois de reiterada solicitação do CLS. Sendo assim, cumpre ressaltar o papel do Estado ${ }^{74}$ brasileiro em atuar imediatamente a qualquer sinal de antissindicalidade, uma vez que a procrastinação é prejudicial aos direitos fundamentais dos trabalhadores e à solução eficaz. De outro modo, a apatia pode caracterizar o ente estatal como um violador de liberdade sindical.

\footnotetext{
${ }^{74}$ O Verbete 817 do CLS destaca o papel do Governo: “El gobierno es responsable de la prevención de todo acto de discriminación antisindical y que debe velar por que todas las quejas contra prácticas discriminatorias de esa índole sean examinadas con arreglo a un procedimiento que además de expeditivo no sólo debería ser imparcial sino también parecerlo a las partes interesadas".In: OIT. La libertad sindical. Recopilación de decisiones del Comité de Libertad Sindical del Consejo de Administración de la OIT. 5. ed. rev. Ginebra: Oficina Internacional del Trabajo, 1976. párrafo n. 817, p. 174.
} 


\subsubsection{Queixas contra Portugal e Espanha}

O arquivo do CLS contabiliza 34 casos encerrados e apenas um ativo de origem portuguesa, enquanto as queixas de origem espanhola totalizam um caso em andamento e noventa e dois encerrados.

Inicialmente, perquiriu-se o caso n. 2.729 advindo de Portugal, o qual foi protocolado pela Confederação Geral dos Trabalhadores Portugueses Intersindical Nacional (CGTP-IN) em 17 de julho de 2009, em desacordo à recente atualização do Código do Trabalho português.

Segundo a proponente, tal revisão ocasionou o surgimento de nova figura jurídica: a possibilidade de "escolher a convenção coletiva". Assim, o art. 497 do referido diploma permite que o trabalhador não filiado, tenha o direito de escolher entre a convenção coletiva ou a decisão arbitral sempre que a empresa aplique um ou mais dos supramencionados instrumentos. Por isso, a norma é vista como desestimuladora à filiação e promove a desfiliação ao colocar os trabalhadores não filiados em situação mais benéfica que a dos filiados, pois enquanto aos indivíduos associados emprega-se a convenção concluída pela entidade sindical, aos outros se oferece a escolha da que melhor lhe convenha, o que afronta as organizações sindicais e seus filiados em típica disposição antissindical, consoante o entendimento da CGTP-IN.

Ademais, a reclamante explicou que tal possibilidade impulsiona a interferência do empregador na escolha do empregado pelo instrumento coletivo atrelado aos ideais empresariais e em detrimento de certos sindicatos.

A queixa também faz referência à empresa CTT Correios de Portugal S.A., a qual estaria obstando a negociação coletiva com o Sindicato dos Trabalhadores dos Correios e Telecomunicações (SNTCT), representante de $65 \%$ dos trabalhadores da empresa. A reclamação decorreu, principalmente pelo firmamento de "acordo de princípio" (2008) entre a supracitada empresa e outra associação sindical que representa $24 \%$ dos seus empregados. Entretanto, o SNTCT não subscreveu o novo acordo e continuou vinculado à antiga convenção coletiva (2006), mas o empregador alegou caducidade sobre esse documento e 
por meio de procedimento de "adesão individual" iniciou a aplicação do no instrumento (2008), inclusive aos filiados do SNTCT.

Invocando a decadência da convenção (2006), a empresa diminuiu o número de dirigentes sindicais com licença sindical completa (aqueles que desempenham atividade sindical em mais de 1.800 locais de trabalho) em notória ofensa à Convenção n. 135 da OIT. Nesse contexto, os filiados ao SNTCT foram convocados ou pressionados a aderirem ao novo documento (2008) de forma escrita, o que gerou a interferência do Departamento de Investigação e Ação Penal, levando às reuniões de conciliação com o Ministério do Trabalho e as partes (SNTCT e empresa).

Após tentativas infrutíferas de arbitragem voluntária, solicitou-se a arbitragem obrigatória para a revisão da convenção (2006) sob a justificativa de invocação de longas e ineficazes negociações, nas quais se verificou a má-fé empresarial e a ausência de ânimo para negociar. Decorridos noventa dias, o Ministério do Trabalho não respondeu ao pedido, mas posicionou-se favoravelmente à caducidade da convenção coletiva (2006).

Na sua primeira conclusão, o CLS lamentou a ausência de resposta do governo português às alegações da querelante. Quanto à possibilidade do art. 496 do Código do Trabalho estimular a desfiliação sindical, o órgão posicionou-se no sentido de que o trabalhador não filiado está em melhor posição para determinar qual sindicato defendeu melhor os interesses da categoria profissional. No que diz respeito à hipótese de interferência empresarial na escolha do trabalhador pela convenção, dispôs que a legislação portuguesa prevê a proteção contra atos de ingerência patronal.

No que concerne à avaliação sobre as práticas contrárias à negociação coletiva da empresa de Correios, o CLS cobrou do Governo lusitano o envio de suas observações acerca das aludidas violações e condutas antissindicais em face do SNTCT, assim como decisões administrativas e judiciais emitidas (inclusive do Departamento de Investigação e Ação Penal) e informações sobre a evolução do conflito desde a apresentação da queixa, fato ocorrido somente em março de 2011. 
O Governo português afirmou que o SNTCT chegou a um acordo com a empresa em julho de 2009, três dias antes da apresentação da denúncia ao CLS, para assinar uma nova convenção coletiva de empresa, que foi concluída em um curto espaço de tempo e publicada em janeiro de 2010. Em decorrência do firmamento de novo acordo entre as partes, o CLS entendeu que não cabia um exame mais detalhado.

Em seguida, analisou-se o Caso n. 2.121 proveniente do ordenamento espanhol, apresentado em 23 de março de 2001 pela União Geral de Trabalhadores da Espanha (UGT) em face do Governo.

A querelante aduziu que a vigência da Lei Orgânica n. 8/2000 sobre direitos e liberdades dos estrangeiros na Espanha e sua integração social indicam graves restrições aos direito básicos por parte do Governo espanhol. Para tanto, a normatização ensejou a limitação do exercício da liberdade de sindicalização e do direito de greve, da manifestação e associação, assim como do direito de negociação coletiva, pois determinou que os estrangeiros tivessem acesso aos citados direitos somente quando obtivessem autorização para permanecer ou residir em território espanhol.

Ademais, a mudança legislativa repentina ocasionou a insegurança jurídica, além de tragédias sociais e familiares entre os imigrantes. Outrossim, violou direitos fundamentais reconhecidos na Constituição, na Declaração Universal dos Direitos Humanos e em outros tratados internacionais ratificados pela Espanha. No que se refere às Convenções da OIT sobre liberdade sindical e outra normas que tutelam direitos trabalhistas, entendeu-se que os estrangeiros também possuem a condição de trabalhadores protegidos, independente do tipo de estadia no país.

Em resposta ao CLS, o Governo espanhol comunicou que os estrangeiros exercem seus direitos previstos na referida lei em situação de igualdade com os espanhóis. Ressaltou também que a desigualdade na compreensão de direitos e liberdades não ocorre entre nacionais e estrangeiros, mas entre "imigrantes legais" e "imigrantes ilegais" (a quem certos direitos são restritos). Ainda de acordo com o Estado, a Lei Orgânica clarificou a situação dos estrangeiros que se encontram legalmente no país, pois dividiu os direitos em 
duas classes: a primeira extensiva a todos os estrangeiros devido a sua natureza fundamental, enquanto a segunda, apenas àqueles em situação regular.

O Estado informou que os textos internacionais reconhecedores de liberdades são de cunho geral, porém, permitem ao legislador nacional o estabelecimento de restrições ou exigências básicas para a aferição de tais direitos, objetivando salvaguardar bens relevantes da sociedade democrática. Para tanto, destacou a Convenção n. 87 e n. 98 da OIT que reconhecem direitos fundamentais, mas carecem de normas jurídicas de desenvolvimento.

Nas considerações finais, o CLS observou que a querelante desejou dar interpretação extensiva ao conceito de "trabalhadores", sem quaisquer distinções ou autorização prévia para que possa se filiar às organizações que julgar convenientes. No que diz respeito à Convenção n. 87, obsta somente os membros das forças armadas e da polícia. Desse modo, o CLS concluiu que todos os trabalhadores, salvo a hipótese mencionada, estão amparados pelo citado diploma internacional.

Por isso, solicitou ao Governo hispânico que considerasse o conteúdo do art. $2^{\circ}$ da Convenção e salientou que os sindicatos devem usufruir o direito de representar e assistir aos trabalhadores, especialmente com a finalidade de promover seus interesses.

\subsubsection{Queixa contra a Alemanha}

A Alemanha possui apenas dez reclamações encerradas e não detém procedimentos em andamento ou ativos junto ao CLS. Por isso, pesquisou-se o Caso n. 2.805 por ser o mais recente, cuja primeira data de apresentação foi em 09 de abril de 2010 pela Freie Arbeiterinnen - und Arbeiter - Union - FAU, a qual se define como um sindicato de base alemão e representa a seção alemã da Associação Internacional dos Trabalhadores (AIT).

A querelante informou que durante um conflito laboral da sua seção de Berlim (Asy-Berlim) com a sala de cinema local Babylon Berlin, em decorrência de um acordo coletivo, um Tribunal local proferiu decisão que 
impediu a FAU de exercer o direito de negociação coletiva e atividades correlacionadas, bem como a possibilidade de se autodenominar sindicato (Gewerkschaft) ou sindicato de base (Basisgewerkschaft), circunstância que a impediu de negociar com o empregador e, desse modo, favoreceu a empresa. Além disso, a direção da sala de cinema requereu a imposição de multa se houvesse o descumprimento da decisão judicial. Por tais motivos, a FAU sustentou ofensa às Convenções n. 87 e n. 98.

A referida proibição foi revogada posteriormente em nome da liberdade de expressão, no entanto, a entidade continuou sem poder atuar como um sindicato. O CLS constatou que a FAU carecia de condição jurídica de sindicato e, consequentemente a FAU-Berlim não estava habilitada a participar das reuniões em nível de empresa. Mas, de acordo com a querelante, viola os princípios da OIT equiparar a obtenção de personalidade sindical à capacidade de conduzir contratos coletivos; além disso, entendeu que não há distinção jurídica entre a negociação coletiva em âmbito empresarial e na escala regional.

O Governo alemão manifestou-se contrário à queixa apresentada e negou a violação aos diplomas internacionais, pois garantem a liberdade sindical e de associação, bem como a negociação coletiva em termos gerais e não consideram a capacidade para concluir contratos coletivos na condição de sindicato. Desse modo, entendeu que a capacidade das organizações de trabalhadores deve sujeitar-se a requisitos mínimos para a conclusão de convênios coletivos, por exemplo, a estrutura organizativa básica que possibilite a execução das suas tarefas e a possibilidade de se afirmar frentes aos interlocutores sociais. Por isso, asseverou que "sólo se puede lograr un equilibrio de intereses a través de un convenio colectivo si la organización de trabajadores es tan eficaz que el empleador se ve obligado a negociar y suscribir un convenio colectivo; de otro modo, todo dependería de la buena voluntad del empleador".

Nas suas ponderações, o CLS recordou que a designação de sindicato mais representativo e apto exclusivamente a negociar, não contraria o art. 3ำ da Convenção n. 87. Ademais, quando o ordenamento adota tal sistemática, o sindicato deve ser determinado a partir de critérios objetivos e previamente determinados para não ensejar parcialidade ou abuso de direito. Para tanto, enfatizou a jurisprudência alemã, a qual dispõe as regras mínimas a serem 
obedecidas pelas entidades aptas a negociarem, assim: 1) de acordo com os estatutos da organização, deve objetivar os interesses dos seus membros na qualidade de empregados; 2) concluir convênios coletivos; 3) constituir-se livremente, não carecer de adversários e ser independente; 4) ser organizado em nível superior no local de trabalho; 5) reconhecer a legislação vigente sobre negociação coletiva; 6) atuar de forma efetiva na negociação coletiva, "lo que implica una cierta firmeza frente al interlocutor social, una posición de fuerza y una cierta eficiencia en la organización”.

Mas, o CLS explicou que a firmeza e a eficiência são insuficientes frente ao empregador, pois as organizações de trabalhadores necessitam de capacidade de negociação de convênios coletivos (característica presente apenas às entidades que possuem a condição de sindicato) e, por consequência, o empreendimento da greve, por exemplo, é extensiva à aptidão de negociar. Já as associações desprovidas de tais condições estão amparadas pela Lei Fundamental alemã, a qual consagra o princípio da liberdade sindical e de associação.

Desse modo, o CLS concluiu que a decisão judicial estava de acordo com os preceitos jurisprudenciais. Além disso, observou que a FAU-Berlim demonstrou firmeza considerável diante da sala de cinema local Babylon Berlim, mas não era o bastante para estabelecer a capacidade de concluir contratos coletivos com efeitos normativos. Por isso, o CLS entendeu que os critérios adotados pelo Tribunal não constituem violações aos princípios de liberdade sindical e de associação, inclusive a querelante tem o direito de tentar novamente a apreciação do Tribunal para o reconhecimento da sua capacidade se houver alteração dos fatos.

A Comissão permanente da OIT também destacou a decisão judicial no que diz respeito ao não reconhecimento da querelante como sindicato e os possíveis efeitos negativos relatados na queixa. De acordo com o Governo alemão, a entidade foi considerada uma associação protegida pelo direito fundamental de liberdade sindical e de associação por lei nacional, o que the proporciona o livre exercício de atividades e de filiação de trabalhadores, enquadrando-se como uma organização de trabalhadores abrangida pela Convenção n. 87. No entanto, o CLS asseverou o dever de garantir às entidades 
minoritárias o direito de serem porta-vozes dos seus membros e de representá-los nas reclamações individuais.

Por fim, solicitou-se ao ente estatal que garanta a FAU-Berlim o desempenho de atividades que possam ampliar e defender os interesses dos seus representados, consoante os preceitos convencionais aludidos, em especial: "expresar su opinión en público, acceder al lugar de trabajo de los miembros del sindicato y, en caso de que goce de representatividad en la empresa en cuestión, participar en las reuniones del comité de empresa". 


\section{CONCLUSÕES}

O fim da Segunda Guerra Mundial significou um novo ciclo para a temática humanitária, qual seja, a imprescindibilidade de reafirmá-la e garanti-la diante das violações ocorridas durante o aludido conflito. De um lado, a Carta Internacional dos Direitos Humanos, reconhecendo os direitos e liberdades imprescindíveis à manutenção da vida; de outro, a Organização Internacional do Trabalho, pormenorizando conteúdos vitais à seara trabalhista.

Nesse contexto protecionista, destaca-se a Convenção n. 87, a qual exalta a liberdade sindical e os direitos inerentes a ela. A liberdade sindical tratase de um direito humano fundamental às relações laborais e detém nuances diversificadas, por exemplo, a possibilidade dos trabalhadores e empregadores constituírem livremente suas organizações sindicais, assim como a garantia de filiação e desfiliação às entidades que julgar conveniente.

Para a efetividade da liberdade sindical nos ordenamentos jurídicos nacionais, é indispensável um cenário adequado à plena manifestação das suas dimensões, o que reflete no sistema legal, no modelo de organização sindical e, especialmente na expressividade dos movimentos sindicais. Outrossim, consiste no empenho da OIT para que os direitos sejam garantidos em todos os Estados, principiando pela ratificação do mencionado diploma internacional.

A despeito dos esforços, há países onde a liberdade sindical é inexistente ou é exercida de forma mitigada, como no Brasil. A estrutura do sindicalismo brasileiro, adotada na primeira metade do século $X X$ e herdada do fascismo italiano, sofreu poucas modificações até a contemporaneidade, renunciou ao modelo completamente corporativista e se tornou um sistema híbrido, em especial após a promulgação da Constituição Federal de 1988, a qual introduziu um regime com características livres e, simultaneamente, manteve elementos intervencionistas, que não permitem o desenvolvimento pleno dos direitos sindicais.

As principais críticas a esse sistema misto estão relacionadas à imposição da unicidade sindical por meio da legislação, a qual impede a 
existência plúrima de sindicatos em determinada base territorial, o que destoa dos princípios de liberdade patrocinados pela OIT.

Defensores do citado modelo organizacional justificam a sua aplicabilidade em decorrência da preservação da forte representatividade e do controle da quantidade de entidades sindicais. No entanto, tal argumento mostra-se falacioso diante da possibilidade de fragmentação de categorias, artifício que redundou no expressivo número de organizações disseminadas pelo território nacional, das quais, muitas com poder de negociação medíocre.

Outrossim, a crise de representatividade é reforçada pela cobrança da contribuição sindical compulsória, a qual permite a sobrevivência financeira dos denominados "sindicatos de carimbo".

Na presente conjuntura, não se pode olvidar do critério de agregação de trabalhadores e empregadores por categoria, o qual remete ao paralelismo simétrico. Obrigatoriamente, a categoria profissional será definida pela atividade econômica preponderante do empregador, salvo nas categorias diferenciadas. Tal metodologia tolhe a liberdade sindical, visto que obsta a formação de agrupamentos por meio da união espontânea, como a decorrente da identidade de profissões.

Ante as observações, constata-se que as violações à liberdade sindical não decorrem puramente de atos e condutas advindos do empregador ou das organizações sindicais. O Estado também pode ser qualificado como um agente antissindical, seja quando revestido da função de empregador e, em especial, ao ocupar o posto de legislador.

Em 2005, a partir de discussões durante o Fórum Nacional do Trabalho - FNT, foram redigidas a Proposta de Emenda Constitucional n. 369 e o Anteprojeto de Lei de Relações Sindicais, com o objetivo de implantar uma reforma na organização sindical brasileira. Tais projetos apresentaram traços inovadores, como a implantação de um sistema de prevenção e repressão de condutas antissindicais.

Por outro lado, mantiveram-se pontos que evidenciam 0 conservadorismo e a completa inadequação com as relações de trabalho hodiernas, o que não possibilita nem mesmo a ratificação da Convenção n. 87 da 
OIT. A título de exemplo, cita-se a exclusividade de representação, instrumento que, na prática, trata da concessão do monopólio sindical (com outra roupagem), uma vez que terá preferência o sindicato constituído anteriormente à nova lei.

Além disso, prevê a extinção da contribuição sindical compulsória e a criação da contribuição de negociação coletiva, cujo valor a ser custeado será superior ao sistema atual e, de fato, de cunho obrigatório, independente da filiação e da garantia satisfatória à classe representada, já que baseada na participação ou no efeito geral do resultado.

Os pontos de retrocesso justificam em parte a tramitação morosa de aproximadamente uma década da PEC n. 369/2005 no Congresso Nacional, todavia, ainda que haja a presença de caracteres anacrônicos, sua aprovação não interessa a diversos grupos satisfeitos com a presente estrutura, como foi demonstrado nos conflitos ocorridos durante as discussões do FNT.

Desse modo, propugna-se uma reforma no sistema sindical brasileiro, a qual compreenda alterações facilitadoras do estabelecimento pleno da liberdade sindical, tais como:

1. Substituir o modelo organizacional denominado unicidade sindical pelo de pluralidade sindical, o qual favoreça a competição entre as entidades e prevaleça a mais representativa, evoluindo para a unidade espontânea;

2. Incentivar a representação dos trabalhadores no local de trabalho, favorecendo a proximidade dos indivíduos com o cotidiano sindical e das entidades com as necessidades imediatas dos seus representados, visando à promoção dos direitos humanos fundamentais;

3. Extinguir a forma de sustentação econômica das organizações sindicais, substituindo-a pelo modelo da contribuição negocial, desde que não mais oneroso aos representados. Ademais, a nova metodologia deverá possibilitar a fiscalização da tentativa de negociação entre as entidades;

4. Extinção do paralelismo simétrico obrigatório, permitindo aos grupos determinarem o melhor critério de agregação de trabalhadores e empregadores, até mesmo o arranjo por categorias, desde que seja decorrente da livre escolha dos interessados; 
5. Ratificar a Convenção n. 87 da OIT sobre "Liberdade Sindical e Proteção ao Direito de Sindicalização" pelo Estado brasileiro e respeitar os diplomas já ratificados referentes à temática, em especial as Convenções $98 \mathrm{e}$ 151, assim como a Declaração da OIT sobre os Princípios Fundamentais no Trabalho;

6. Empenho do Estado brasileiro para cumprir os direcionamentos do Comitê de Liberdade Sindical e fiscalizar a ação dos agentes antissindicais em potencial, assim como seguir as orientações gerais da OIT;

7. Revisar o texto da PEC n. 369 e do Anteprojeto de Lei de Relações Sindicais para que se torne adequado à realidade das relações de trabalho contemporâneas, incluindo os atores sociais excluídos da proteção coletiva, como o trabalhador autônomo, o eventual e o terceirizado;

8. Implantar um sistema preventivo e repressivo de atos e condutas antissindicais, no qual seja possível a efetividade da norma jurídica por meio da aplicação de sanções rigorosas aos violadores de liberdade sindical e dos direitos a ela inerentes;

9. Estabelecer maior comunicabilidade e apoio das organizações superiores aos sindicatos de base, visando ao seu fortalecimento, em especial para consolidar a negociação coletiva como um instrumento efetivo para a melhoria das condições de trabalho. Mas, o negociado não deverá prevalecer sobre o legislado quando se almejar apenas a flexibilização de direitos.

Evidentemente, os apontamentos acima não formam um rol exaustivo de medidas para a concretização da liberdade sindical plena. Além disso, a substituição da legislação sindical vigente de traços intervencionistas por outra considerada progressista, por si só, não será capaz de reverter a crise que assola o sindicalismo brasileiro.

Outrossim, deve-se evitar receitas prontas do direito comparado, isto é, não intentar a mera transposição de modelos realizados em outros países, ainda que tenham sido bem sucedidos na origem. Há que se considerar as particularidades da realidade brasileira, como dados econômicos, políticos e sociais, em seguida, ponderar a metodologia estrangeira ao contexto nacional. 
Essa diligência faz-se necessária para não incorrer em oportunismos e comodismos como no sistema vigente.

Para tanto, o movimento sindical precisa ser revigorado e resgatar seus ideais clássicos de luta por melhores condições de trabalho, os quais poderão reavivar a confiança perdida dos atores sociais.

Atualmente, a maioria das classes enxerga o sindicato como um "parasita", que almeja exclusivamente a usurpação da contribuição sindical anual para garantir a manutenção de "cabides de emprego", e tais preconceitos são decorrentes da atuação pífia de certas organizações.

Ademais, o trabalhador carece de uma formação educacional que propicie maior conscientização do seu papel na constituição do direito coletivo, a qual deve ser conduzida pelas entidades sindicais.

No decorrer do trabalho, manifestou-se a defesa da liberdade sindical como um direito humano fundamental, isto é, inerente às relações de trabalho e, consequentemente, atrelado à manutenção da dignidade de cada ator social. Sendo assim, não há que se cogitar a aplicação limitada ou prejudicada, visto que os direitos humanos fundamentais são universais, indivisíveis e imprescritíveis, ou seja, não comportam quaisquer diminuições. 


\section{REFERÊNCIAS BIBLIOGRÁFICAS}

AGUILAR CAVALLO, Gonzalo. Derechos fundamentales-derechos humanos. ¿Una distinción válida en el siglo XXI? Boletin Mexicano de Derecho

Comparado. México, v.43, n.127, p.15-71. ene./abr. 2010.

ALEXY, Robert. Teoria dos direitos fundamentais. 5.ed. Trad. Virgílio Afonso da Silva. São Paulo: Malheiros, 2008.

ALMEIDA, José Maria de. Reforma sindical cria superpelegos. Folha de são Paulo, Opinião, São Paulo, 21 abr. 2005. Disponível em:

<http://www1.folha.uol.com.br/fsp/opiniao/fz2104200510.htm>. Acesso em maio 2014.

ALONSO OLEA, Manuel. Derecho del trabajo. 6.ed. Madrid: Universidad de Madrid - Facultad de Derecho, 1980.

ALVES, José Augusto Lindgren. A arquitetura internacional dos direitos humanos. Coord. Hélio Bicudo. São Paulo: FTD, 1997.

ARAUJO, Adriane Reis de. A liberdade sindical e os atos anti-sindicais no direito brasileiro. Revista do Ministério Público do Trabalho, Brasília, ano XVI, n. 32, p. 29-48, out. 2006.

AROUCA, José Carlos. Repensando o sindicato. São Paulo: LTr, 1988.

Reforma da legislação sindical: relatório do Fórum Nacional do Trabalho: primeira leitura. LTr: revista legislação do trabalho. São Paulo, v.68, n.5, p.52434, maio. 2004.

. Curso básico de direito sindical. São Paulo: LTr, 2006.

. Quem tem medo da convenção n. 87? LTr: Legislação do Trabalho.

Suplemento Trabalhista, São Paulo, v. 48, n. 155, p. 799-805, 2012. 
BARROS, Alice Monteiro de. Representante dos empregados no local de trabalho. Revista do Tribunal Regional do Trabalho da 3ª Região, Belo Horizonte, n. 58, p. 179-188, jan./dez. 1998.

Condutas anti-sindicais - procedimento. Revista do Tribunal Regional do Trabalho da 3 ${ }^{a}$ Região, Belo Horizonte, n. 59, p. 29-44, jan.jun. 1999.

Curso de direito do trabalho. 5.ed. São Paulo: LTr, 2009.

Barata Silva, C. A. Liberdade sindical - unidade e pluralidade. In: TEIXEIRA FILHO, João de Lima. Relações coletivas de Trabalho. Estudos em homenagem ao Ministro Arnaldo Süssekind. São Paulo: LTr, 1989.

BARROS JUNIOR, Cássio de Mesquita. Registro de entidade sindical. In: MANNRICH, Nelson. (Coord.) Atualidades do direito do trabalho: anais da academia nacional de direito do trabalho. São Paulo: LTr, 2012.

BATALHA, Wilson de Souza Campos. Sindicatos. Sindicalismo. São Paulo: LTr, 1992.

BAYLOS, Antonio; TERRADILLOS, Juan. Derecho penal del trabajo. Madrid: Trotta, 1997.

BORGES, Altamiro. Encruzilhadas do sindicalismo. São Paulo: Anita Garibaldi, 2005.

BOROWSKI, Martin. La estructura de los derechos fundamentales. Trad. Carlos Bernal Pulido. Bogotá: Universidad Externado de Colombia, 2003.

BRONSTEIN, Arturo S. In: ERMIDA URIARTE, Oscar; OJEDA AVILÉS, Antonio. (Coord.) El derecho sindical em america latina. Montevideo: Fundación de Cultura Universitaria, 1995.

CABANELLAS, Guilhermo. Derecho sindical y corporativo. Buenos Aires: Atalaya, 1946.

Compendio de derecho laboral. Buenos Aires: Bibliográfica Omeba, 1968. 
CANOTILHO, J. J. Gomes. Direito constitucional e a teoria da constituição. 4.ed. Coimbra: Almedina, 2000. ; MOREIRA, Vital. Constituição da república portuguesa anotada. 3.ed. rev. Coimbra: Coimbra, 1993.

CARUSO, Bruno. Le relacione sindicali. Torino: G. Giappichelli Editore, 2004.

CARVALHO NETO, Antônio Moreira de. Liberdade e autonomia sindical no Brasil: meio século de atraso na aplicação da convenção no 87 da OIT. In: PEREIRA, Armand F. (Org.). Reforma sindical e negociação coletiva. Brasília: OIT, 2001.

CATHARINO, José Martins. Tratado elementar de direito sindical: doutrina, legislação. São Paulo: LTr, 1977.

CESARINO JR., A. F. Direito social brasileiro. 6.ed. ampl. e atual. com a colaboração de Marly A. Cardone. São Paulo: Saraiva, 1970.

COLLA, Filippo; ROTONDI, Francesco. Il comportamento antisindacale. (aspetti sostanziali e processuali). Milani: CEDAM, 2004.

COMPARATO, Fábio Konder. A afirmação histórica dos direitos humanos. 6.ed. rev. e atual. São Paulo: Saraiva, 2001.

CRIVELLI, Ericson. Democracia sindical no Brasil. São Paulo: LTr, 2000.

D’EUFEMIA, Giuseppe. Diritto sindacale. Napoli: Morano Editore, 1967.

DALLARI, Dalmo de Abreu. Direitos humanos e cidadania. São Paulo: Moderna, 1998.

Dallari, Dalmo de Abreu. Os 50 anos da declaração universal dos direitos do homem e do nascimento de um novo direito. In: SOUZA, Carlos Aurélio Mota de; BUENO, Roberto. 50 anos de direitos humanos. São Paulo: Themis, 2003.

DELGADO, Mauricio Godinho. Curso de direito do trabalho. 12.ed. São Paulo: LTr, 2013. 
DIANEZI, Vicente. Buraco Negro. Reforma sindical do governo corre risco de engavetamento. Revista Consultor jurídico, 29 abr. 2005. Disponível em: <http://www.conjur.com.br/2005-abr-29/reforma_sindical_governo_corre_risco_ engavetamento>. Acesso em: maio 2014.

DUNNING, Harold. Orígenes del convenio num. 87 sobre libertad sindical y derecho de sindicación. Revista Internacional del Trabajo, Genebra, v. 117, n. 02, p. 153-166.

ERMIDA URIARTE, Oscar. A proteção contra os atos anti-sindicais. Trad. Irany Ferrari. São Paulo: LTr, 1989.

FECOMERCIO. Fecomercio propõe alternativa ao projeto de reforma sindical. Tome Nota. Informativo de legislação trabalhista, previdenciária e sindical, n. 20, São Paulo, maio 2005.

FERRAJOLI, Luigi. Derechos y garantias. La ley del más débil. Madrid: Editorial Trotta, 2004.

FIORAVANTE, Tamira Maira. Sindicato, educação e liberdade. São Paulo: LTr, 2008.

FNT. Espaço de diálogo e negociação. Reforma sindical: perguntas e respostas. 2.ed. rev. e atual. Brasília: Ministério do trabalho e emprego, 2005.

FRANCO FILHO, Georgenor de Sousa. (Coord.) Curso de direito coletivo do trabalho. Estudos em homenagem ao ministro Orlando Teixeira da Costa. São Paulo: LTr, 1998.

FRANCO, Tomás Sala; MONTESINOS, Ignacio Albiol. Derecho sindical. Valentia: Tirant Lo Blanch

FREITAS JÚNIOR, Antônio Rodrigues de. Sindicato: domesticação e ruptura. Um estudo de representação sindical no direito brasileiro. São Paulo: Ordem dos Advogados do Brasil, 1989.

A negociação coletiva do trabalho e o projeto de reforma sindical de 2005. Revista do Departamento de Direito do Trabalho e da Seguridade Social, São Paulo, v.1, n.1, p.9-14, jan./jun. 2006. 
FREITAS JÚNIOR, Antônio Rodrigues de. Novas perspectivas para o direito coletivo do trabalho no Brasil (ou sobre a premência da disciplina legal da conduta antissindical). Revista do Advogado, São Paulo, v.30, n.110, p.17-23, dez. 2010

GALANTINO, Luisa. Diritto Sindicale. Torino: G. Giappichelli Editore, 1996.

GARCIA, Gustavo Filipe Barbosa. Liberdade sindical: condutas antissindicais e atuação do Ministério Público do Trabalho. Revista Justiça do Trabalho, Porto Alegre, v.30, n.358, p.7-18, out. 2013.

GERNIGON, Bernard. El convenio núm. 98 de la OIT: un instrumento que sigue siendo de actualidad cincuenta años después de su adopción. Educación Obrera. Genebra, v.1/2, n.114/115, p.19-23, 1999.

GIUGNI, Gino; CURZIO, P.; GIROFALO, M. G. Direito Sindical. Trad. Eiko Lucia Itioka. Rev. José Francisco Siqueira Neto. São Paulo: LTr, 1991.

GOMES, Orlando; GOTTSCHALK, Elson. Curso de direito do trabalho. 17.ed. atual. por José Augusto Rodrigues Pinto e Otávio Augusto Reis de Sousa. Rio de Janeiro: Forense, 2005.

GONÇALVES, João Carlos. Desafios e perspectivas para o diálogo social no brasil: o modelo sindical brasileiro e a reforma sindical. Revista do Tribunal Superior do Trabalho, Brasília, vol. 76, n. 4, p. 105-109, out/dez 2010.

HERKENHOFF, João Baptista. Curso de direitos humanos. Gênese dos direitos humanos. Guarulhos/SP: Acadêmica, 1994. v. I.

HINZ, Henrique Macedo. Mais um olhar sobre a reforma sindical. LTR:

Legislação do Trabalho. Suplemento Trabalhista, São Paulo, v.42, n.39, p.17781, 2006.

HOUAISS, Antônio. Dicionário houaiss da língua portuguesa. Rio de Janeiro: Objetiva, 2009.

HUNT, Lynn._A invenção dos direitos humanos: uma história. Trad. Rosaura Eichenberg. São Paulo: Companhia das Letras, 2009.

ISRAEL, Jean-Jacques. Direito das liberdades fundamentais. Trad. Carlos Souza. Barueri/SP: Manole, 2005. 
KAUFMANN, Marcus de Oliveira. A anti-sindicalidade e o anteprojeto de lei de relações sindicais. Revista do Tribunal Superior do Trabalho, Brasília, vol. 71, n. 2, p. 188-229, maio/ago. 2005.

KELLERSON, Hilary. La declaracion de la OIT de 1998 sobre los principios y derechos fundamentales: un reto para el futuro. Revista Internacional del Trabajo, Ginebra, v.117, n.2, p.243-8, 1998.

LAFER, Celso. Declaração universal dos direitos humanos (1948). In: MAGNOLI, Demétrio. (Org.) História da paz: os tratados que desenharam o planeta. São Paulo: Contexto, 2008.

LEVI, Alberto. A repressão da conduta anti-sindical na Itália. In: FREDIANI, Yone; ZAINAGHI, Domingos Sávio (Coord.). Relações de direito coletivo brasil-itália. São Paulo: LTr, 2004.

LOGUERCIO, José Eymard. Pluralidade sindical. Da legalidade à legitimidade no sistema sindical brasileiro. São Paulo: LTr, 2000.

MACIEL, José Alberto Couto. Papel das centrais sindicais. In: FRANCO FILHO, Georgenor de Sousa. (Coord.) Curso de direito coletivo do trabalho. Estudos em homenagem ao Ministro Orlando Teixeira da Costa. São Paulo: LTr, 1998.

MACIEL, José Alberto Couto. Contribuição de negociação coletiva: lesão aos trabalhadores na reforma sindical. LTr: Legislação do Trabalho. Suplemento Trabalhista, São Paulo, v.41, n.44, p.175-7, 2005.

MAGANO, Octávio Bueno. Organização sindical brasileira. São Paulo: Ed. Rev. dos Tribunais, 1981.

MAGANO, Octávio Bueno. Direito coletivo do trabalho. 3.ed. São Paulo: LTr, 1993. v. 3.

MAGANO, Octávio Bueno. Proposta de emenda constitucional e convenção n. 87 da OIT. Revista LTr, São Paulo, vol. 63, n. 01, jan. 1999.

MAGANO, Octávio Bueno. Dicionário jurídico-econômico das relações de trabalho. São Paulo: Saraiva, 2002. 
MANGLANO, Carlos Molero. Derecho sindical. Madrid: Dykinson, 1996.

MARTINEZ, Luciano. Condutas antissindicais. São Paulo: Saraiva, 2013.

MARTINS, Sergio Pinto. Direito do Trabalho. 29.ed. São Paulo: Atlas, 2013.

MASSONI, Túlio de Oliveira. Sindicatos: criação e registro. In: SANTOS, Enoque Ribeiro dos; SILVA, Otávio Pinto e. (Coord.) Temas controvertidos do direito coletivo do trabalho no cenário nacional e internacional. São Paulo: LTr, 2006.

Representatividade sindical. São Paulo: LTr, 2007.

MAZZONI, Giuliano. Relações coletivas de trabalho. Trad. Antonio Lamarca. São Paulo: Ed. Revista dos Tribunais, 1972.

MEIRELLES, Davi Furtado. Liberdade sindical: o modelo ideal. LTr: Revista Legislação do Trabalho. São Paulo, v.74, n.5, p.542-52, maio. 2010.

MENEZES, Cláudio Armando Couce de. Proteção contra condutas anti-sindicais (atos anti-sindicais, controle contra discriminação e procedimentos anti-sindicais). Revista do Tribunal Superior do Trabalho, Brasília, vol. 71, n. 2, p. 44-55, maio/ago. 2005.

MONTESQUIEU, Charles de Secondat. O espírito das leis. Trad. Cristina Murachco. São Paulo: Martins Fontes, 2000.

MORAES, Alexandre de. Direitos humanos fundamentais. Teoria geral. Comentários aos arts. 1 a 5을 da Constituição da República Federativa do Brasil. Doutrina e jurisprudência. 7.ed. São Paulo: Atlas, 2006.

MUNOZ, Jairo M. De los derechos humanos a los derechos de los pueblos. Una historia de libertad, democracia y auto determinacion. Franciscanum: revista de las ciencias del espiritu. Bogota, v.32, n.94, p.31-44, ene./abr. 1990.

NASCIMENTO, Amauri Mascaro. Origens históricas e natureza jurídica dos sindicatos. In: FRANCO FILHO, Georgenor de Sousa. (Coord.) Curso de direito coletivo do trabalho. Estudos em homenagem ao ministro Orlando Teixeira da Costa. São Paulo: LTr, 1998. 
NASCIMENTO, Amauri Mascaro. Problemas que dificultam a reforma sindical. LTr: revista legislação do trabalho. São Paulo, v.71, n.6, p.647-53, jun. 2007.

Curso de direito do trabalho. 24.ed. São Paulo: Saraiva, 2009.

Compêndio de direito sindical. 7.ed. São Paulo: LTr, 2012.

NICOLADELI, Sandro Lunard. A natureza jurídica da liberdade sindical e sua normatividade internacional. In: NICOLADELI, Sandro Lunard; PASSOS, André Franco de Oliveira; FRIEDRICH, Tatyana Scheila. $O$ direito coletivo, a liberdade sindical e as normas internacionais. São Paulo: LTr, 2013. v. I.

NOGUEIRA, Eliana dos Santos Alves. Direito do trabalho e justiça do trabalho: panorama e perspectivas em face das atuais reformas. Revista do Tribunal Regional do Trabalho da 15a Região, Campinas, n.26, p.87-98, jan.jun. 2005.

OJEDA AVILÉS, Antonio. Compendio de derecho sindical. Madrid: Tecnos, 1998.

OIT. Casos del Comité de Libertad Sindical (NORMLEX)

As normas internacionais do trabalho. Manual de educação obreira. Genebra: Repartição Internacional de Trabalho, 1978.

Participación de los trabajadores em las decisiones de la empresa. Ginebra: Oficina Internacional del Trabajo, 1981.

El Comité de Libertad Sindical: impacto desde su creación. Oficina Internacional del Trabajo: Ginebra, 2001.

OIT. La libertad sindical. Recopilación de decisiones del Comité de Libertad Sindical del Consejo de Administración de la OIT. 5. ed. rev. Ginebra: Oficina Internacional del Trabajo, 2006.

OIT. Relatório Global de Acompanhamento da Declaração da OIT relativa aos Princípios e Direitos Fundamentais no Trabalho. Liberdade sindical na prática: lições a retirar. Organização Internacional do Trabalho, Genebra, 2008. 
OIT. Declaración. Antecedentes. Disponível em:

<http://www.ilo.org/declaration/thedeclaration/background/lang--es/index.htm> Acesso em: agosto de 2013.

PALOMBELLA, Gianluigi. Dai diritti umani ai diritti fondamentali: sulle conseguenze di una distinzione concettuale. Sociologia del Diritto. Milano, v.31, n.2, p.61-107, 2004.

PASSOS, André Franco de Oliveira; FRIEDRICH, Tatyana Scheila. Direito internacional e liberdade sindical: da teoria geral à necessidade de aplicação prática. In: NICOLADELI, Sandro Lunard; PASSOS, André Franco de Oliveira; FRIEDRICH, Tatyana Scheila (Org.). O direito coletivo, a liberdade sindical e as normas internacionais. São Paulo: LTr, 2013. v. I.

PASSOS, Edésio. Reflexões e propostas sobre a reforma trabalhista e sindical. LTr: revista legislação do trabalho. São Paulo, v.67, n.5, p.519-35, maio. 2003.

PASTORE, José. Reforma sindical: para onde o Brasil quer ir? São Paulo: LTr, 2003.

PEREIRA, Ricardo Jose Macedo de Britto. Novas perspectivas do direito coletivo do trabalho no Brasil. In: SANTOS, Élisson Miessa; CORREIA, Henrique. Estudos aprofundados MPT: Ministério Público do Trabalho. Salvador: JusPODIVM, 2012.

PÉREZ LUÑO, Antonio Enrique. Derechos humanos, estado de derecho y constitucion. 8.ed. Madrid: Tecnos, 2003.

PERONE, Giancarlo. Lo statuto dei lavoratori. Torino: Utet, 1997.

PIMENTA, Joaquim. Sociologia econômica e jurídica do trabalho. 5.ed. Rio de Janeiro: Freitas Bastos, 1957.

PINTO, Almir Pazzianotto. A contra-reforma sindical. Síntese Trabalhista, Porto Alegre, v.16, n.191, p.5-7, maio. 2005.

PINTO, Almir Pazzianotto. Convenção 87. Revista de Direito do trabalho. São Paulo, v. 31, n. 119, p. 11-14, jul./set. 2005. 
PINTO, Roberto Parahyba de Arruda. Pela aprovação da convenção no 87 da OIT, pelo Congresso Nacional, nos termos doa rtigo $5^{\circ}$, $\S 3^{\circ}$, da Constituição Federal. Revista do Advogado: AASP, São Paulo, v. 28, n. 97, p. 184-190, maio 2008.

PIOVESAN, Flávia. Direitos humanos globais, justiça internacional e o Brasil. In: AMARAL JÚNIOR, Alberto; MOISÉS, Cláudia Perrone. O cinqüentenário da declaração universal dos direitos do homem.São Paulo: Universidade de São Paulo, 1999.

. Direitos Humanos e o direito constitucional internacional. 9.ed. rev., ampl. e atual. São Paulo: Saraiva, 2008.

PRADO, Roberto Barreto. Curso de direito sindical. São Paulo: LTr, 1991.

QUEIROZ, Antônio Augusto de. As razões da derrota do Governo na reforma sindical. Departamento Intersindical de Assessoria Parlamentar, Brasília, 23 fev. 2006. Disponível em: <http://www.diap.org.br/index.php?>. Acesso em maio 2014.

RAMOS, André de Carvalho. Teoria geral dos direitos humanos na ordem internacional. 2.ed. São Paulo: Saraiva, 2012.

RAYMOND, Wilfredo Sanguineti. Lesion de la libertad sindical y comportamientos antisindicales. Estúdio de la estructura y el contenido del juicio de antisindicalidad. Madrid: Ministerio de Trabajo y Seguridade Social, 1993.

RODRIGUES, Leôncio Martins. Destino do sindicalismo. São Paulo: Edusp, 1999.

ROLLI, Claudia. Reforma sindical vai aumentar custos, diz indústria. Folha de São Paulo, Mercado, São Paulo, 16 mar. 2005. Disponível em: < http://www1.folha.uol.com.br/fsp/dinheiro/fi1603200516.htm>. Acesso em maio 2014.

ROMITA, Arion Sayão. Organização sindical. Revista Síntese Trabalhista. Porto Alegre, v. 15, n. 171, p. 09-24, set. 2003.

Parábola do bananal sindical brasileiro. Revista da Academia Nacional de Direito do Trabalho. São Paulo, v.12, n.12, p.57-8, 2004. RUSSOMANO, Mozart Victor. Princípios gerais de direito sindical. 2.ed. ampl. e atual. Rio de Janeiro: Forense, 1995. 
SANTOS, Enoque Ribeiro dos. Direitos Humanos na Negociação Coletiva: Teoria e Prática Jurisprudencial. São Paulo: LTr, 2004.

Fundamentos do direito coletivo do trabalho nos Estados Unidos da América, na união européia, no mercosul e a experiência brasileira. Rio de Janeiro: Lumen Juris, 2005.

Reforma sindical e emenda constitucional n. 45/2004: fontes formais de sustentação do novo modelo sindical. In: SANTOS, Enoque Ribeiro dos; SILVA, Otávio Pinto e. (Coords.) Temas controvertidos do direito coletivo do trabalho no cenário nacional e internacional. São Paulo: LTr, 2006.

SANTOS, Ronaldo Lima dos Santos. Sindicatos e ações coletivas. Acesso à justiça, jurisdição coletiva e tutela dos interesses difusos, coletivos e individuais homogêneos. 3.ed. São Paulo: LTr, 2012.

Teoria das normas coletivas. São Paulo: LTr, 2007.

SARLET, Ingo Wolfgang. A eficácia dos direitos fundamentais. Uma teoria geral dos direitos fundamentais na perspectiva constitucional. 10.ed. rev., atual. e ampl. Porto Alegre: Livraria do Advogado, 2009.

SILVA, Homero Batista Mateus da. Curso de direito do trabalho aplicado. Direito coletivo do trabalho. 2.ed. rev. e ampl. Rio de Janeiro: Elsevier, 2012. v. 7.

SILVA, José Afonso da. Curso de direito constitucional positivo. 22.ed. rev. e atual. São Paulo: Malheiros, 2003.

SILVA, Otávio Pinto e. A contratação coletiva como fonte do direito do trabalho. São Paulo: LTr, 1998.

O Brasil precisa de uma reforma sindical? In: SANTOS, Enoque Ribeiro dos; SILVA, Otávio Pinto e. (Coord.). Temas controvertidos do direito coletivo do trabalho no cenário nacional e internacional, São Paulo: LTr, 2006.

SILVA, Sayonara Grillo Coutinho Leonardo. Relações coletivas de trabalho entre a mudança e a conservação: perscrutando o projeto de emenda constitucional 369 e o anteprojeto de lei da reforma sindical. Revista de Direito do Trabalho. São Paulo, v.31, n.119, p.185-204, jul./set. 2005. 
SILVA, Walküre Lopes Ribeiro da. Crise de representatividade e participação dos sindicatos em políticas ativas de emprego. 2001. $333 \mathrm{f}$. Tese (Professor Titular) - Faculdade de Direito, Universidade de São Paulo, São Paulo, 2001. ; LIMA, Firmino Alves. Repressão penal dos atos antissindicais. Revista do Tribunal Regional do Trabalho da 15ª Região, Campinas, n. 37, p. 67-84, 2010.

SIQUEIRA NETO, José Francisco. Liberdade sindical e representação dos trabalhadores nos locais de trabalho. São Paulo: LTr, 1999.

- Liberdade sindical e representação dos trabalhadores nos locais de trabalho no Brasil: obstáculos e desafios. In: PEREIRA, Armand F. (Org.). Reforma sindical e negociação coletiva. Brasília: OIT, 2001.

SÜSSEKIND, Arnaldo. Convenções da OIT. 2.ed. São Paulo: LTr, 1998. . Direito internacional do trabalho. 3.ed. São Paulo: LTr, 2000. ; MARANHÃO, Délio; VIANNA, Segadas; TEIXEIRA, Lima. Instituições de direito do trabalho. 22.ed. São Paulo: LTr, 2005. v.II.

TEIXEIRA, Gilnei M. Liberdade sindical no Brasil: uma visão estratégica. In: OIT. Reforma sindical e negociação coletiva. Brasília, DF: OIT, 2001.

TRATADO DE VERSALHES. Disponível em: <http://avalon.law.yale.edu/imt/partxiii.asp.>. Acesso em: julho de 2013.

TRINDADE, Antônio Augusto Cançado. A proteção internacional dos direitos humanos: fundamentos jurídicos e instrumentos básicos. São Paulo: Saraiva, 1991.

VALVERDE, A. M.; GUTIÉRREZ, F. R. S.; MURCIA, J. G. Derecho del trabajo. 5.ed. Madrid: Tecnos, 1996.

VARGAS, João Tritan. Qual é o liberalismo da Lei Chapelier? Seu significado para os contemporâneos e para a historiografia francesa dos séculos XIX e XX.

Revista Mundos do Trabalho, vol. 3, n. 5, jan./jun. 2011. 
VASCONCELOS FILHO, Oton de Albuquerque. Liberdades sindicais e atos anti-sindicais. São Paulo: LTr, 2008.

VEGA RUIZ, María Luz. Reforma laboral en América Latina. Educación Obrera. Genebra, n.143/144, p.87-95, 2006.

VERLAINE, Marcos. Artigos. Reforma sindical: $1 / 3$ do Congresso é contrário ao texto produzido pelo FNT. Departamento Intersindical de Assessoria Parlamentar, Brasília, 08 maio 2005. Disponível em: < http://www.diap.org.br/index.php?>. Acesso em maio 2014.

VIANA, Márcio Túlio. O movimento sindical, o congresso da CUT e a reforma brasileira. LTr: revista legislação do trabalho. São Paulo, v.67, n.12, p.1413-23, dez. 2003.

A reforma sindical, entre o consenso e o dissenso. Revista do Tribunal Superior do Trabalho, Brasília, vol. 70, n. 2, p. 52-71, jul./dez. 2004.

VIANNA, José de Segadas. Direito coletivo do trabalho. São Paulo: LTr, 1972.

. Organização sindical. In: SÜSSEKIND, Arnaldo; MARANHÃO, Délio;

VIANNA, Segadas; TEIXEIRA, Lima. Instituições de direito do trabalho. 22.ed. São Paulo: LTr, 2005. v.II.

VILLAVICENCIO RIOS, Alfredo. A liberdade sindical nas normas e pronunciamentos da OIT. Trad. Jorge Alberto Araujo. São Paulo: LTr, 2011.

WEBB, Sidney; WEBB, Beatriz. The history of trade unionism. New York: Longmans, Green, 1950.

WEIS, Carlos. Direitos humanos contemporâneos. 2.ed. São Paulo: Malheiros, 2010.

ZYLBERSTAJN, Hélio. A reforma sindical de Lula. Revista de Direito do Trabalho, São Paulo, v.31, n.119, p.94-116, jul./set. 2005. 